\title{
SABERES TRADICIONAIS E LOCAIS: reflexões etmobiológicas
} Organização: Marcelo Guerra Santos \& Mariana Quinteiro

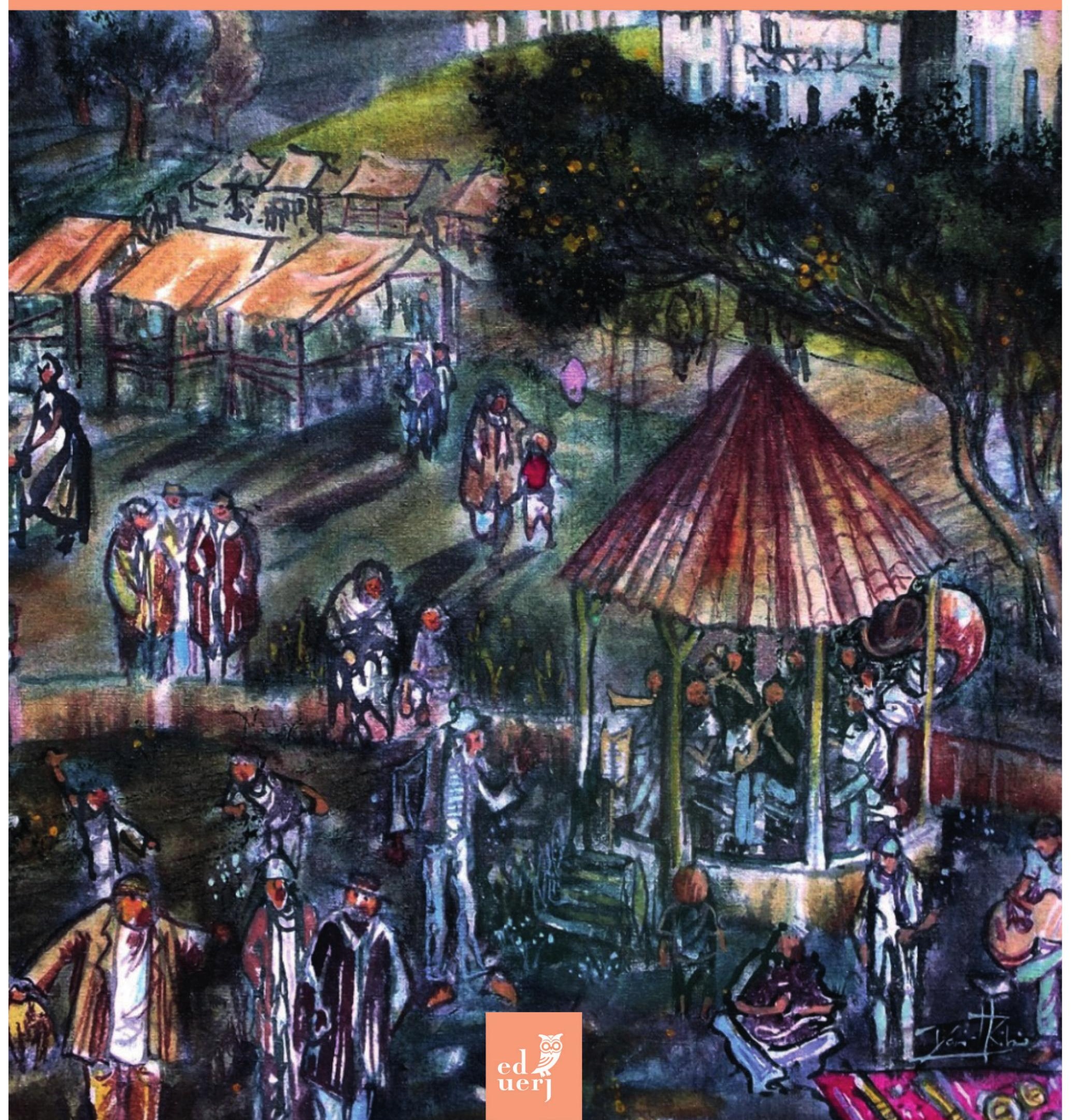




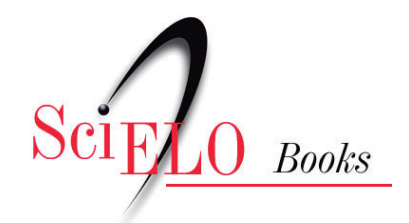

\title{
Saberes tradicionais e locais reflexões etnobiológicas
}

\author{
Marcelo Guerra Santos \\ Mariana Quinteiro \\ (orgs.)
}

\section{SciELO Books / SciELO Livros / SciELO Libros}

SANTOS, M.G., and QUINTERO, M., comps. Saberes tradicionais e locais: reflexões etnobiológicas [online]. Rio de Janeiro: EDUERJ, 2018, 191 p. ISBN: 978-85-7511-485-8. https://doi.org/10.7476/9788575114858.

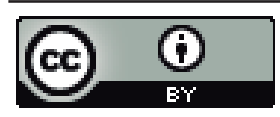

All the contents of this work, except where otherwise noted, is licensed under a Creative Commons Attribution 4.0 International license.

Todo o conteúdo deste trabalho, exceto quando houver ressalva, é publicado sob a licença Creative Commons Atribição $\underline{4.0}$.

Todo el contenido de esta obra, excepto donde se indique lo contrario, está bajo licencia de la licencia $\underline{\text { Creative }}$ Commons Reconocimento 4.0. 
Saberes tradicionais e locais 
UNIVERSIDADE DO ESTADO DO RIO DE JANEIRO

Reitor

Ruy Garcia Marques

Vice-reitora

Maria Georgina Muniz Washington

ed 髞

EDITORA DA UNIVERSIDADE DO ESTADO DO

RIO DE JANEIRO

Conselho Editorial

Glaucio José Marafon (presidente)

Henriqueta do Coutto Prado Valladares

Hilda Maria Montes Ribeiro de Souza

Italo Moriconi Junior

José Ricardo Ferreira Cunha

Lucia Maria Bastos Pereira das Neves

Luciano Rodrigues Ornelas de Lima

Maria Cristina Cardoso Ribas

Tania Maria Tavares Bessone da Cruz Ferreira

Anibal Francisco Alves Bragança (EDUFF)

Katia Regina Cervantes Dias (UFRJ) 


\author{
Marcelo Guerra Santos \\ Mariana Quinteiro \\ (Organização)
}

\title{
Saberes tradicionais e locais Reflexôes etnobiológicas
}

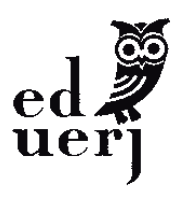

Rio de Janeiro 2018 


\section{Copyright (c) 2018, EdUERJ}

Todos os direitos desta edição reservados à Editora da Universidade do Estado do Rio de Janeiro. É proibida a duplicação ou reprodução deste volume, ou de parte do mesmo, em quaisquer meios, sem autorização expressa da editora.

\section{EdUERJ \\ Editora da UNIVERSIDADE DO ESTADO DO RIO DE JANEIRO \\ Rua São Francisco Xavier, 524 - Maracanã}

CEP 20550-013 - Rio de Janeiro - RJ - Brasil

Tel./Fax.: 55 (21) 2334-0720 / 2334-0721

www.eduerj.uerj.br

eduerj@uerj.br

Editor Executivo

Coordenadora Administrativa

Coordenadora Editorial

Assistente Editorial

Coordenador de Produção

Supervisor de Revisão

Revisão

Capa

Projeto Gráfico

Diagramação
Glaucio Marafon

Elisete Cantuária

Silvia Nóbrega

Thiago Braz

Mauro Siqueira

Elmar Aquino

João Martorelli / Iris Figueiredo

Júlio Nogueira

Emilio Biscardi

Editora Morandi

S115 Saberes tradicionais e locais : reflexões etnobiológicas [recurso eletrônico] / Marcelo Guerra Santos, Mariana Quinteiro, organização. - Rio de Janeiro : EdUERJ, 2018.

1 recurso online (192 p.) : ePub.

e-ISBN 978-85-7511-485-8

1. Biologia. 2. Botânica. 3. Ecologia. I. Santos, Marcelo Guerra. II. Quinteiro, Mariana. 


\section{SUMÁRI0}

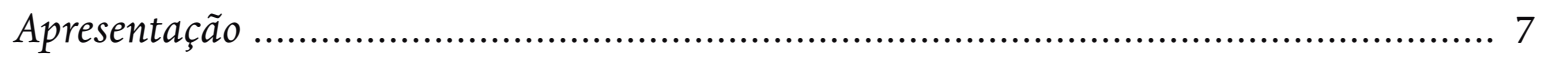

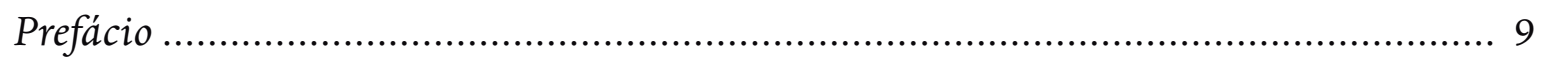

CAPÍTULO I. Saberes tradicionais e a história da paisagem................................ 15

Rogério Ribeiro de Oliveira

CAPÍTULO II. Agroecologia e as práticas tradicionais: reconhecendo

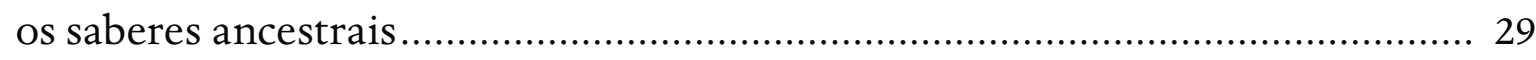

Mariana Martins da Costa Quinteiro e Karla Beatriz Lopes Baldini

CAPÍTULO III. Saberes tradicionais e a segurança alimentar.

Odara Horta Boscolo e Joyce Alves Rocha

CAPÍTULO IV. Plantas medicinais: saberes tradicionais e o sistema de saúde. 73

Marcelo Guerra Santos e Ana Cecília Bezerra Carvalho

CAPÍTULO V. Pesquisas etnobotânicas em unidades de conservação

no estado do Rio de Janeiro, Brasil 101

Viviane Stern da Fonseca Kruel, Juan Gomes Bastos e Cyl Farney Catarino de Sá

CAPÍTULO VI. Os saberes tradicionais e locais e as indicações geográficas:

o caso das plantas medicinais do Brasil

Lucia Regina Rangel de Moraes Valente Fernandes, Sandra Aparecida Padilha Magalhães Fraga e Vanise Baptista da Costa

CAPÍTULO VII. Saberes tradicionais e o desafio da multiculturalidade nas instituições de ensino. 149

Mariana Martins da Costa Quinteiro e Lana Cláudia Fonseca

CAPÍTULO VIII. Relatos históricos e sustentabilidade: um campo de possibilidades fundamentado na etnobotânica 169

Luci de Senna Valle, Maria Franco Trindade Medeiros e Luiz José Soares Pinto

Sobre os autores 183

Sobre o ilustrador 191 


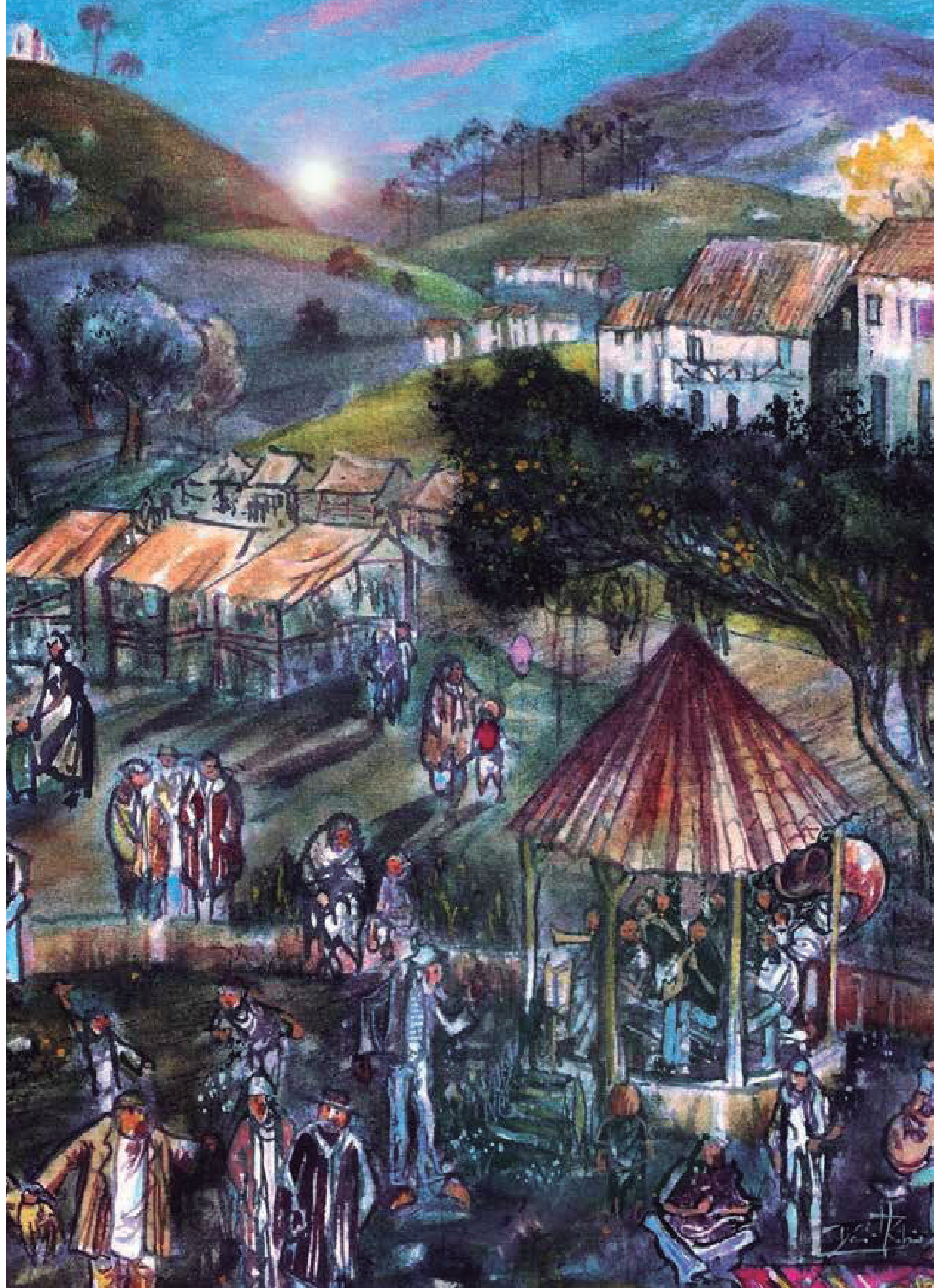




\section{APRESENTAÇĀO}

A conservação da natureza passou a fazer parte das prioridades das sociedades modernas. Confrontada com diferentes formas de degradação, em escala planetária, a humanidade atual tem como um de seus principais enfoques a proteção do mundo natural. Nesse contexto, a biodiversidade tem ganhado especial destaque, com grande ênfase dada às espécies de flora, fauna de determinada região.

Tornou-se assim comum a crença de que o paradigma do uso ilimitado dos recursos naturais deve ser substituído pelo paradigma da "sustentabilidade", que sugere responsabilidades socioambientais nas mais diversas dimensões do "estar no mundo" pelo ser humano. Em torno do conceito de "sustentabilidade" estão reunidos diferentes grupos sociais, que buscam uma visão alternativa de futuro para responder efetivamente à crise ambiental.

Para alcance desse objetivo, foram criadas diferentes formas de políticas públicas, Unidades de Conservação, currículos acadêmicos e escolares, protocolos de plantio e de segurança alimentar, entre outras ações.

Entretanto, a simples implantação dessas iniciativas não é suficiente para proteção e recuperação dos ecossistemas ameaçados, sendo necessária a inclusão de propostas de manejo para que a própria sociedade seja responsável pela sua conservação. A nova concepção da sustentabilidade requer uma mudança fundamental na percepção de que o meio ambiente não está limitado aos ecossistemas biofísicos, mas inclui uma rede de interações entre a consciência humana, os sistemas sociais e o meio natural.

O conceito de "etnobiodiversidade" nos mostra que a diversidade biológica é influenciada não apenas pelas condições ecológicas, mas também pelas tradições culturais e a experiência acumulada por comunidades humanas durante o manejo de seu ambiente. 
Assim, muito se tem discutido sobre o impacto negativo da sociedade humana sobre a biodiversidade, em especial pelo forte desequilíbrio gerado pelas sociedades industrializadas modernas. Entretanto, pouco se tem estudado sobre como comunidades locais exploram, conservam e enriquecem a biodiversidade, compondo a "sociodiversidade" de determinada região.

Muitos ecossistemas brasileiros abrigam comunidades humanas de grande diversidade sociocultural, que desenvolveram estilos de vida relacionados aos ambientes naturais específicos, com suas visões de mundo particulares, conhecimento extenso e minucioso dos processos naturais. Estabelecem, também, relações com o mundo natural distintas das que prevalecem nas sociedades urbano-industriais.

É evidente que, nessas discussões, generalizações não são apropriadas em nenhum dos sentidos. Incorreria um erro a visão simplista do "Mito do bom selvagem", romantizando as formas de viver das comunidades tradicionais como sempre sendo de impactos positivos em seus meios naturais. Igualmente, as sociedades modernas promovem incríveis avanços no sentido da proteção da biodiversidade.

O que se propõe aqui é uma reflexão ao nosso modelo de conservação e educação vigentes, base da "sustentabilidade" que buscamos alcançar, considerando a importância dessas culturas rústicas, de seu resgate e valorização. Algumas perguntas que nortearam os apontamentos que se seguem versam sobre os "saberes tradicionais" da sua relevância em um mundo globalizado.

Qual a importância de trazer à tona essas formas tradicionais de conceber o universo se as culturas e os modos de observação da realidade que nos cerca se encontram em constante mudança?

Quais ferramentas dispomos para tanto, ou seja, como podemos exercer práticas em que esses saberes sejam, efetivamente, ressignificados?

Marcelo Guerra Santos Mariana Martins da Costa Quinteiro 


\section{PREFÁCIO}

É com prazer que prefacio a antologia Saberes tradicionais e locais: reflexões etnobiológicas, coordenada por Marcelo Guerra Santos e Mariana Quinteiro. Retomo algumas indagações feitas na apresentação desta publicação sobre a importância dos conhecimentos tradicionais na sociedade moderna em constante mudança e seus impactos nos povos tradicionais indígenas e outras comunidades tradicionais.

Em extenso levantamento bibliográfico, publicado sob o título Saberes tradicionais e biodiversidade no Brasil, ${ }^{1}$ constatou-se um aumento significativo no número de trabalhos sobre conhecimentos tradicionais. Até essa data, a maioria desses trabalhos era de antropólogos que estudavam os povos indígenas. A partir dos anos 1990, a maioria desses trabalhos já é realizada por etnobiólogos, etnobotânicos e etoictiólogos, entre outros, usando um enfoque de etnociência, em particular nos estudos sobre comunidades quilombolas (77\%), ribeirinhos/caboclos amazônicos (64\%), pantaneiros $(74 \%)$, pescadores artesanais (61\%), caiçaras (60\%) etc.

Em razão do aumento de pesquisadores desse campo de conhecimento, foi criada, em 1996, a SBEE, Sociedade Brasileira de Etnobiologia e Etnoecologia, que através de seus simpósios, conferências e publicações tem divulgado, sobretudo no meio acadêmico, os resultados de suas pesquisas.

O ensino das várias disciplinas da etnociência, especialmente a etnobotânica, a etnobiologia e a etnoicitiologia, tem avançado muito nesses últimos anos. Se até os anos 1980 a maioria dos trabalhos nessa área era feita nos departamentos de antropologia, a partir de então começaram a

1 DIEGUES, A. C. e ARRUDA, R. S. V. (orgs.). Saberes tradicionais e biodiversidade no Brasil. Brasília: Ministério do Meio Ambiente; São Paulo: USP, 2001. 
surgir disciplinas de etnoecologia oferecidas por professores em departamentos, principalmente os de biologia e os de botânica. Na década de 1990, diversos cursos começaram a incorporar as etnociências em suas grades curriculares. Atualmente, disciplinas ligadas às etnociências são oferecidas em oito universidades brasileiras, sendo nove cursos nas áreas de agronomia, biologia, farmácia e engenharia florestal.

O crescente número de trabalhos em etnoecologia, a partir da década de 1990, pode ser explicado tanto por razões internas a esse campo acadêmico como por razões externas.

Entre as razões internas está o desencanto de inúmeros estudantes de graduação e pós-graduação das ciências naturais pela falta de interesse nos departamentos por questões sociais e culturais ligadas à conservação da natureza. No Brasil, poucos cursos de biociências oferecem disciplinas de ecologia humana. O estabelecimento de cursos interdisciplinares de pós-graduação envolvendo sociedades e meio ambiente, bem como disciplinas das ciências naturais e humanas, ofereceu aos pesquisadores das ciências naturais, sobretudo aos biólogos e aos ecólogos, a possibilidade de um trabalho conjunto e a oportunidade da utilização dos métodos da etnoecologia com um enfoque mais etnográfico.

Entre as causas externas que motivaram o crescente interesse por essa área do conhecimento está a maior visibilidade social dos povos e comunidades tradicionais que passaram a defender seus territórios. Estes encontravam-se ameaçados pela especulação imobiliária, pelas questões fundiárias estruturais do Brasil e pelos grandes projetos, como os das hidroelétricas e autoestradas, a expansão do agronegócio e o estabelecimento de áreas protegidas - parques nacionais, por exemplo - das quais essas populações foram expulsas ou tiveram suas atividades tradicionais (a pequena agricultura, a pesca, o extrativismo) severamente limitadas. Entre essas populações, sobressaem os ribeirinhos e caboclos da Amazônia que se rebelaram contra a invasão de seus territórios pela indústria madeireira e pelo agronegócio, e que, no final da década de 1980, culminou com o assassinato de seu líder principal, Chico Mendes.

As longas e acaloradas discussões entre preservacionistas e socioambientalistas sobre o papel das comunidades tradicionais nas áreas protegidas, no âmbito do Sistema Nacional de Áreas Protegidas, a partir de meados da década de 1980, resultou no reconhecimento, pelo governo, da importância do conhecimento tradicional e da própria existência de 
inúmeros povos e comunidades tradicionais. Como resultado, foi criado, no ano de 2000, o Sistema Nacional de Unidade de Conservação em que aparecem novas categorias de Unidades de Conservação (Reserva de Desenvolvimento Sustentável - RDS - e Reserva Extrativista - RESEX). Com isso, pode-se dizer que o conhecimento tradicional sobre a biodiversidade e a participação social são elementos-chave para o êxito do que foi chamado, por alguns autores, de etno-conservação.

Além disso, a mobilização desses povos e comunidades levou o governo a criar, em 2006, a Comissão Nacional de Povos e Comunidades Tradicionais (CNPCT), reunindo as lideranças indígenas e de diversas comunidades tradicionais. Em 2007, foi instituída a Política Nacional de Desenvolvimento dos Povos e Comunidades Tradicionais que, entre outros tópicos, reconhece a importância dos conhecimentos tradicionais. Apesar dessas declarações, pouco tem sido feito pelo governo para colocar em prática medidas consideradas vitais pelos povos e comunidades tradicionais, sobretudo o reconhecimento dos seus territórios e a incorporação dos conhecimentos tradicionais nos planos de manejo de unidades de conservação e no uso dos recursos naturais no mar e na floresta. É clara a resistência dos grupos hegemônicos tanto no governo como em muitas instituições de ensino e pesquisa em utilizar os conhecimentos e práticas tradicionais, e isso tem a ver com a ecologia política e com a aliança entre o poder e a ciência.

O reconhecimento da importância do conhecimento tradicional, sobretudo para a conservação da biodiversidade, iniciou-se a nível internacional, mesmo antes que isso tenha ocorrido no Brasil.

É importante ressaltar que internacionalmente já se esboçava, a partir da década de 1980 um reconhecimento das populações e seus conhecimentos tradicionais no planejamento e implementação das áreas protegidas. O documento da UICN: Estratégia Mundial para a Conservação (1980) menciona a importância do conhecimento tradicional para a conservação e recomenda o incentivo aos sistemas de manejo tradicionais da natureza. Na publicação da ONU, Nosso Futuro Comum (1986), afirma-se necessário incorporar as sociedades minoritárias que têm as características dos grupos tradicionais, incluindo seu conhecimento tradicional.

Concomitantemente, também a nível internacional, pesquisadores, intelectuais e ativistas reunidos em torno da revista Cultural Survival saem em defesa das sociedades e grupos tradicionais, afirmando, em 1985, que 
as áreas protegidas poderiam conservar também os modos de vida tradicionais ou diminuir os ritmos das mudanças a níveis mais aceitáveis e controlados pelos moradores locais.

O maior passo no reconhecimento do conhecimento tradicional se deu na conferência da ONU sobre meio ambiente, no Rio de Janeiro, quando foi aprovada a Convenção da Biodiversidade, em 1992, da qual o Brasil é signatário e hoje ocupa a presidência da CDB.

Essa Convenção Internacional recomenda, no artigo 8, que os benefícios derivados do uso dos conhecimentos e práticas tradicionais, quando usados para fins comerciais, sejam também distribuídos entre as comunidades que os detém.

Além disso, no artigo 10, a COP determina que cada parte contratante "proteja e encoraje o uso tradicional dos recursos biológicos de acordo com as práticas culturais compatíveis com a conservação ou os requisitos do uso sustentável" e que "apoie as populações locais para desenvolver e implementar ações de recuperação em áreas degradadas onde a diversidade biológica tenha sido reduzida" (artigo 10d). Em seu artigo 17, a Convenção também recomenda às partes contratantes que encorajem o intercâmbio de informação sobre o conhecimento das comunidades tradicionais e, no artigo 18, determina o desenvolvimento de métodos de cooperação para o desenvolvimento de tecnologias, incluindo as tecnologias tradicionais e indígenas.

A partir dessas recomendações, uma comissão na CDB foi criada para discutir e propor soluções sobre como os povos tradicionais e as comunidades locais deverão ser beneficiadas, incluindo também temas como o consentimento prévio informado etc. Essa comissão reuniu um número cada vez maior de representantes de governos, povos indígenas e comunidades locais, ONGs e institutos de pesquisa, transformando-se num fórum em que as demandas desses povos e comunidades são apresentadas, sobretudo aquelas referentes a respeito do seu território.

A valorização do conhecimento tradicional também teve como uma das causas a organização dos povos indígenas, a partir dos anos 1970. Em 1982, foi criado junto à ONU o Grupo de Trabalho sobre Populações Indígenas. Em 1989, foi adotada a Convenção n. ${ }^{0} 169$ da Organização Internacional do Trabalho sobre Povos Indígenas e Tribais em Países Independentes (1993), visando garantir seus direitos, sobretudo ao território . 
Em 2000, foi criado o Fórum Permanente dos Povos Indígenas e, em 2007, a Assembleia Geral da ONU aprovou a Declaração dos Direitos dos Povos Indígenas. A questão do respeito aos direitos dos povos indígenas a seu território e a proteção de seus conhecimentos tradicionais têm sido uma das demandas recorrentes do Fórum Permanente dos Povos Indígenas.

A presente coletânea traz análises e informações relevantes sobre a contribuição do conhecimento tradicional para a conservação da biodiversidade, para a segurança alimentar, para a saúde através das plantas medicinais e outras práticas nativas. Enfatiza também a não-incorporação desses conhecimentos e práticas nos currículos do ensino fundamental e médio, mesmo em regiões em que é relevante o número de comunidades tradicionais, como a quilombola, os caboclos, caiçaras, entre outros. Ela, sem dúvida, pode desempenhar um papel importante no debate sobre os conhecimentos e práticas tradicionais e seus desafios acadêmicos e sociais.

Antonio Carlos Diegues Professor da Universidade de São Paulo 


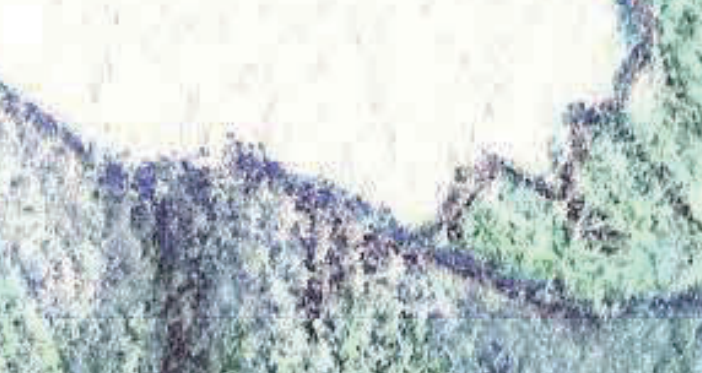




\section{CAPÍTUL0 I \\ Saberes tradicionais e a história da paisagem}

Rogério Ribeiro de Oliveira

\section{Introduçăo}

As paisagens são sempre impregnadas de passado. Essencialmente polissêmica e multiespacial, a paisagem guarda características que misturam passado e presente. Por esse motivo, o estudo da história ambiental, feito com o ferramental da história, da geografia, da biologia e de outras ciências, tem contribuído para uma análise integrada da paisagem, que abarca tanto a dimensão humana como a dimensão física e biológica dos ecossistemas. São como "heranças das sucessivas relações entre homem e natureza" (Santos, 2008), podendo ser vistas tanto como um produto da coevolução das sociedades humanas e do meio natural (Naveh e Lieberman, 1994) quanto como a expressão territorial do metabolismo que uma dada sociedade mantém com o sistema natural que a sustenta (Tello et al., 2006). Se por um lado a paisagem representa simultaneamente a marca e a matriz de processos naturais e sociais, por outro, encontra-se em "permanente construção e reconstrução ao longo do tempo" (Pádua, 2010).

Esse permanente estado de construção e desconstrução é, em grande medida, feito por populações passadas. Esses usos históricos representaram, portanto, uma significativa transformação de muitos biomas tropicais, principalmente no que se refere à geração de extensas áreas de florestas secundárias. Por outro lado, essas populações deixaram muito pouco em termos de documentação escrita acerca da história da formação da paisagem. Roderick Nash, um dos primeiros autores a utilizar o termo história ambiental, no final da década de 1960, sugeriu que a paisagem fosse interpretada como um documento histórico (Worster, 1981). 
No caso do Brasil, dispõe-se de documentação farta sobre a história do vencedor (como o dono de engenho, o fazendeiro de café) e não sobre a do vencido (as etnias indígenas, as populações interioranas, quilombolas, caiçaras etc.). Essa história passa a ter concretude apenas inserida na paisagem, ou seja, trata-se de um "documento", explicitado pelas numerosas marcas encontradas no interior das florestas.

Para a compreensão dos processos de transformação da paisagem na escala da existência humana, importa a consideração de dois de seus pilares: a cultura e o território. A cultura, neste contexto, diz respeito às formas de apreensão de recursos naturais por parte das sociedades ao longo do tempo. Já o território, posto que polissêmico, comporta múltiplas dimensões: a simbólica, a jurídica, a territorial etc. Apesar de sua etimologia ${ }^{1}$ evocar um controle físico ou um exercício do poder, os territórios são também exercidos e apropriados pelo seu uso, cuja percepção confere ao ser humano o sentido de pertencimento, pois ali exerce e desenvolve a sua cultura local. Assim, a reconstrução da história da atividade humana sobre o espaço geográfico é assentada sobre os territórios, manifestados em diferentes escalas, tanto espaciais como temporais. Ao longo da história foram se estabelecendo usos superpostos, formando uma realidade única, prenhe de efeitos sinergéticos. Esses efeitos podem aparecer na composição, estrutura e funcionalidade dos ecossistemas (Oliveira e Fraga, 2012).

Um ecossistema é composto pelo componente biótico e abiótico de um dado espaço, integrando fluxos de energia e matéria. Em termos de escala, constitui uma delimitação teórica em cima de uma rede desses fluxos. Nessa rede, interagem organismos e fatores ambientais, organizados em níveis tróficos e ligados por fluxos de energia e matéria. O ecossistema é, portanto, multiescalar e apriorístico - depende da escala determinada pelo observador. Portanto, como um modelo teórico, tem a sua existência concreta apenas manifestada na paisagem, ou seja, imerso na torrente de processos, sejam eles evolutivos, estocásticos, biológicos ou sociais.

1 Existem duas acepções etimológicas para território: 1) do latim territorium "terra em torno de uma cidade ou de um domínio"; 2) derivada de terrere "assustar", assim territorium significaria "um lugar a partir do qual as pessoas estão alertadas". (Online Etimology Dictionary. Londres: Douglas Harper, 2001. Disponível em: http://www.etymonline.com/ index.php. Acesso em: 14 dez. 2013). 
Assim, nesta perspectiva, o ecossistema está para a paisagem assim como ela está para o território. A paisagem tem sua concretude e o seu vetor de transformação a partir dos territórios que nela se estabeleceram ao longo do tempo. Neste sentido, podemos entender que parte do ofício do historiador ambiental é a identificação e o reconhecimento dos territórios que existiram em uma determinada área e em um dado tempo. Ao longo da história, a ocupação humana sobre o planeta foi moldando a paisagem e por ela sendo moldada. Trata-se, portanto, da manifestação da complexa relação entre as dinâmicas naturais e intencionalidades humanas (Bezerra, 2013).

Em função das características ecológicas das florestas tropicais e, em particular, da Mata Atlântica, os conhecimentos produzidos por populações que historicamente ali viveram sofrem uma verdadeira seleção de práticas. O resultado é uma convergência entre processos culturais bastante distantes entre si, no que se refere ao tempo ou ao espaço. Populações seculares ou milenares, atuando sobre um mesmo ecossistema, promovem a consolidação de um conjunto de conhecimentos comuns e similares acerca do seu manejo, independentemente de sua identidade cultural. O melhor exemplo disso é a agricultura de coivara, praticada com mínimas diferenças em quase todo o território brasileiro em diferentes tempos. A onipresença dessas práticas culturais invoca, portanto, um outro importante aspecto da paisagem, o trabalho humano.

\section{A dimensăo do trabalho na paisagem}

Uma parte muito considerável do que chamamos "paisagem natural" constitui um produto da agência e do trabalho humano e, ao ser admirada como natural, importa muito se suprimimos dela o trabalho ou se o reconhecemos (Willians, 2011). Não obstante, as interações de populações e ocupações pretéritas com diversos ecossistemas vêm sendo negligenciadas, não somente no discurso ambiental, como também em estudos de ecologia. Decodificar a paisagem significa (re)conhecer o trabalho humano nela impresso. Tais usos, ordenados pelas intencionalidades, necessidades e adaptações das populações passadas que estabeleceram seus antigos territórios e uma vez refeitos pelas dinâmicas naturais, são parte substancial daquilo que hoje chamamos de "natureza". 
Esse mosaico de usos na paisagem, em muitos de seus aspectos, faz com que os biomas, particularmente a atual Mata Atlântica, sejam constituídos, em grande parte, por territórios utilizados pelas populações que os habitaram. A cada uso superposto no tempo e no espaço, podem ser esperadas resultantes ecológicas distintas, de acordo com a transformação imposta por cada território e pela dinâmica natural dos ecossistemas. Tais transformações acontecem em um cenário de diversidade cultural (que envolve os conhecimentos e práticas de seus habitantes) e de diversidade biológica, que constituem um patrimônio de imenso valor potencial. Ao longo do tempo, a sucessão desses usos deixa marcas, se espacializa e se sobrepõe como paleoterritórios - conceito proposto como uma parte do processo sucessional e definido como a territorialização das resultantes ecológicas decorrentes do uso dos ecossistemas por populações passadas (ou por uma atividade econômica) na busca de suas condições de existência (Oliveira, 2008). Como estes estão em constante em transição social e ecológica, os paleoterritórios contam histórias profundas acerca da relação sociedade/natureza. Constituem, portanto, um enfoque e um caminho analítico para o historiador ambiental entender as dinâmicas da transformação da paisagem e das sociedades por meio do trabalho. Ao mesmo tempo, os paleoterritórios refletem saberes de populações passadas acerca do seu processo de sobrevivência.

Em termos de tamanho e gênese, os paleoterritórios podem apresentar escalas e origens diversas. Um paleoterritório pode ser o resultado da forma de uso de uma única cultura agindo em uma mesma área por um curto tempo ou, pelo contrário, muitas culturas agindo em um vasto espaço por muito tempo.

A distribuição da castanha-do-Brasil (Bertholletia excelsa) exemplifica o caso de um vasto paleoterritório moldado ao longo do tempo por muitas culturas. Trata-se de uma árvore de grande porte, cujas sementes (a castanha-do-Pará) representam o produto florestal não madeireiro mais importante de toda a região amazônica. Alguns estudos enfocando a sua distribuição descontínua na bacia amazônica propuseram a hipótese de que o padrão de sua distribuição é antrópico (Shepard Jr. e Ramirez, 2011; Ribeiro et al., 2014). Observações de campo e estudos etnográficos sugeriram que práticas culturais específicas facilitaram a sua expansão através da Amazônia. 
Apesar do possível impacto demográfico causado pela intensidade de colheita de castanha do Brasil, algumas evidências históricas sugerem que as atividades humanas passadas tenham favorecido a castanheira e que baixos níveis de colheita tenham desempenhado um papel positivo no recrutamento da espécie (Clements et al., 2003). Fenótipos observados em populações de castanheiras evidenciam um grau de seleção que denota uma domesticação incipiente da espécie. Várias características da planta são compatíveis com uma colonização recente de Bertholletia excelsa pela Amazônia. Sua baixa diversidade genética pode ser atribuída a uma expansão geográfica relativamente rápida e recente, há cerca de 2.000 anos antes do presente (Shepard Jr. e Ramirez, 2011). Este recuo no tempo, que faz convergir a história evolutiva das espécies com a presença do homem, permite investigar a história humana em um marco temporal mais amplo (Pádua, 2010). Assim, o viés do paleoterritório é uma das bases que ampliam o recorte temporal e espacial da história ambiental. Afinal, o "que poderia ser considerado fora dos padrões, que estaria na 'pré-história', mediante o uso da temporalidade científica, está presente em escalas cada vez maiores nas pesquisas; milhares e milhões de anos fariam parte do recorte histórico" (Colacios, 2013).

O exemplo acima remete a uma possível intencionalidade acerca da criação de uma paisagem voltada para atender às necessidades humanas. No entanto, usos ou cadeias de usos pretéritos podem dar origem a alterações não intencionais, com reflexos na biodiversidade dos ecossistemas, como veremos a seguir, com o caso dos fabricantes de carvão do século XIX no Rio de Janeiro. No caso anterior e no que veremos a seguir, o vetor e transformação é o trabalho humano.

Em numerosos trechos de florestas da América Central e do Sul, são encontrados vestígios de antigas carvoarias. Historicamente, a lenha sempre acompanhou a trajetória humana como fonte energética de primeira necessidade. A sua transformação em carvão via combustão abafada (os fornos de carvão) possibilita um aumento do poder calórico com uma redução de massa, o que o torna uma fonte de energia que permite ser transportada a distâncias mais longas. O poder calorífico do carvão vegetal por unidade do peso é quase três vezes maior do que a lenha. Ao contrário do petróleo, o carvão pode ser produzido localmente e trata-se de uma fonte de energia cujo custo de produção é composto quase exclusivamente do trabalho humano investido nele (Olson, 1991). 
No estado do Rio de Janeiro um contingente muito significativo destas carvoarias data do final do século XIX. Apenas no Maciço da Pedra Branca (localizado na Zona Oeste do Rio de Janeiro), atualmente recobertas por densa floresta atlântica, foram encontrados, até o momento, vestígios de mais de 1.000 antigas carvoarias (Oliveira e Fraga, 2012). Atualmente essas carvoarias encontram-se inteiramente recobertas por florestas secundárias (figura 1).

Figura 1. Platô de uma antiga carvoaria do século XIX no Maciço da Pedra Branca, RJ

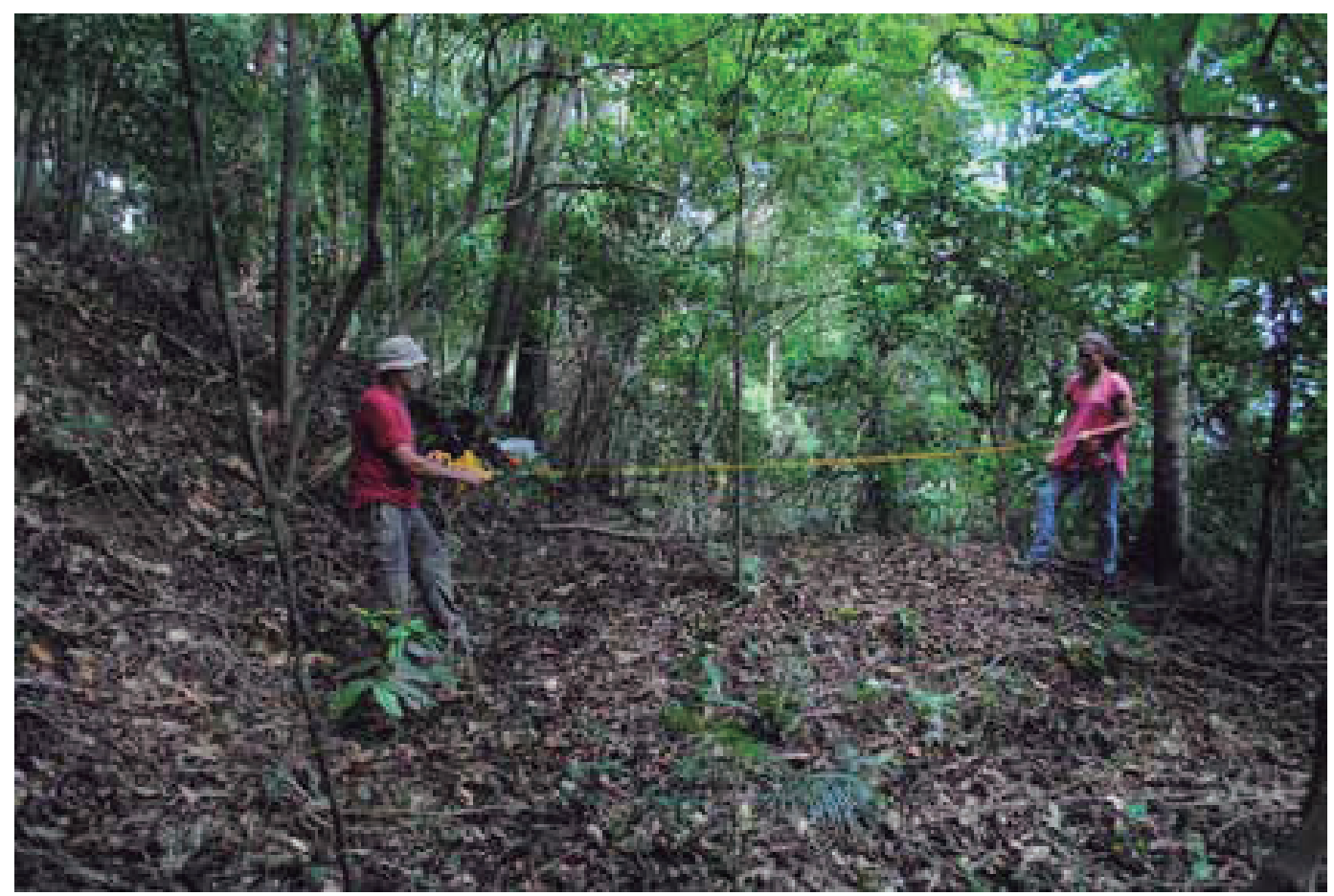

Em grande parte, os carvoeiros eram quilombolas ou escravos alforriados. Mas, mesmo antes da abolição da escravatura no Brasil, em 1888, os escravos foram aos poucos sendo colocados à parte das atividades produtivas. Com a abolição, passaram a constituir um grande contingente de desempregados e com parcos recursos para a sobrevivência. Sem a subsistência provida pelos seus donos, esses ex-escravos se viram, de uma hora para outra, tendo que sustentar a si mesmos e às suas famílias. Privados de acesso à terra ou aos meios de produção, um caminho "fácil" ou, mais provavelmente, incontornável, foi se tornar carvoeiro. 
A fabricação do carvão constituía uma atividade que permitia relativa independência, já que a quantidade de insumos utilizada na produção de carvão era mínima. Junto com lenhadores, os carvoeiros penetravam por toda a parte nas serranias do Rio de Janeiro, onde não se tinham estabelecido os sitiantes. Muito possivelmente a fabricação de carvão era um trabalho para escravos alforriados ou pequenos agricultores, e não parte integrante do sistema produtivo dos engenhos.

O carvão era fabricado no interior da floresta. Para isso, tudo o que precisavam era de uma enxada, um machado e uma pederneira (tipo de isqueiro). Com esses três objetos era possível fabricar o carvão. Mas como isso era feito? A primeira coisa era estar próximo a uma fonte de lenha. O Maciço da Pedra Branca, com uma vasta floresta, garantia o suprimento de lenha. Era ainda necessária a abertura de uma área plana onde a carvoaria era instalada, já que a produção do carvão era feita na própria floresta (figura 2).

Figura 2. Esquema de uma carvoaria e seu balăo de carvăo, evidenciando 0 corte do talude

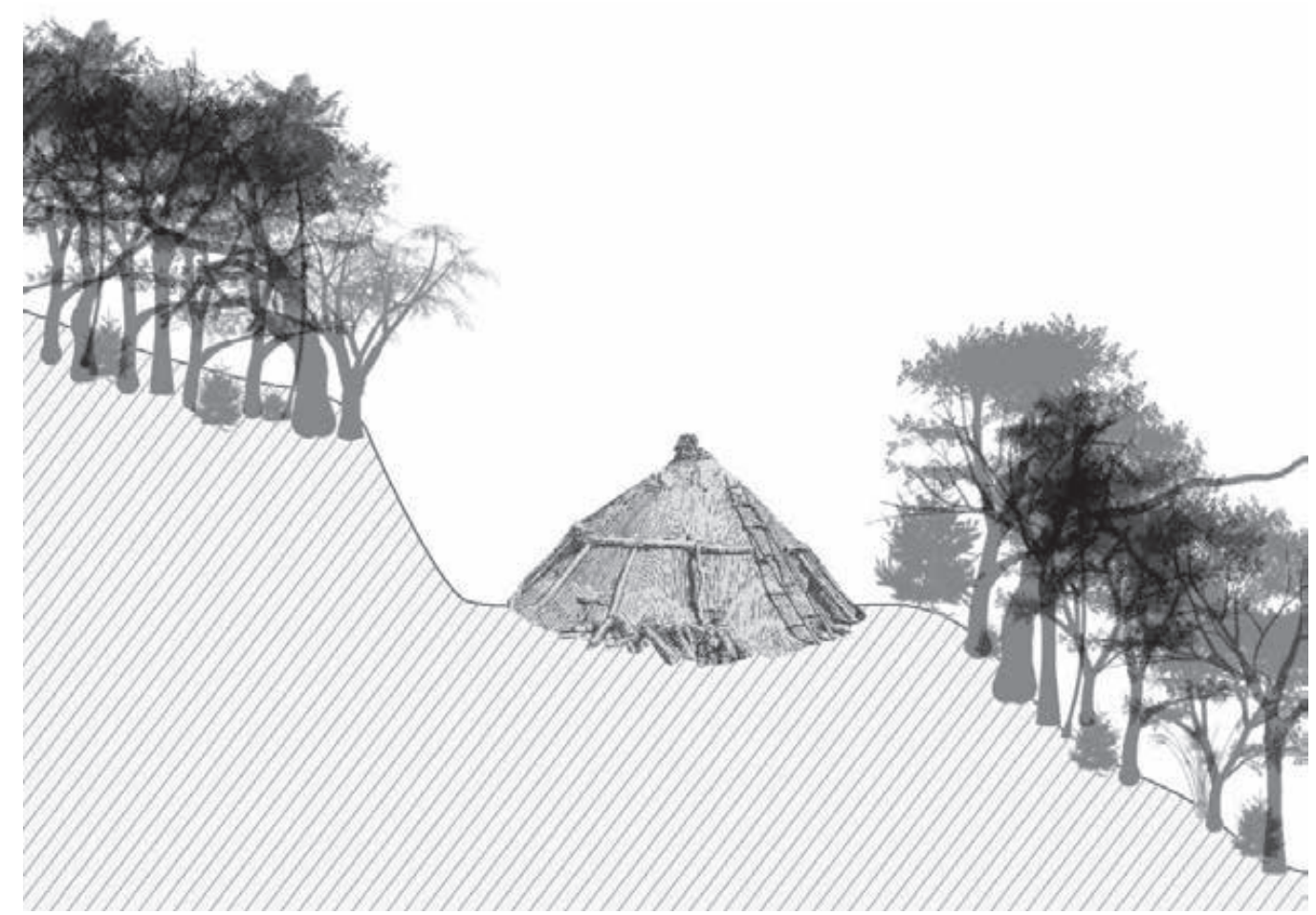


Apesar do intenso processo de invisibilização social a que os carvoeiros estavam sujeitos, somente no Maciço da Pedra Branca, eles foram responsáveis pela exploração de uma área de mais de 10 mil hectares. Hoje, transformado em um Parque Estadual, sua floresta atlântica tem a sua estrutura e composição florística em grande parte determinada por essa atividade do passado. As implicações ecológicas da exploração da lenha para a produção de carvão não resultaram em efeitos negativos expressivos. Essas mil carvoarias inventariadas devem ter produzido mais de 13 mil toneladas de carvão ${ }^{2}$ para uma cidade que tinha neste recurso sua principal matriz energética. No entanto, apesar do intenso desmatamento no final do século XIX, a floresta retornou, graças à sucessão ecológica, constituindo hoje o Parque Estadual da Pedra Branca. Outra evidência da recuperação do sistema é em relação à biodiversidade. Um levantamento feito nas áreas de exploração de carvão inventariou 350 espécies de árvores e arbustos em uma área de um hectare (Freire, 2010). O que se pode observar é que, apesar da composição da floresta ter sido comprometida em parte, sua estrutura e funcionalidade foram significativamente recuperadas. A consequência ecológica mais significativa foi possivelmente a redução da diversidade, mas não de biomassa.

Há, porém, um desfecho nessa história ligado à sustentabilidade. Apesar do desmatamento, a sustentabilidade ecológica do período de fabricação do carvão foi um fato concreto. Afinal, a retomada da floresta nessa área de exploração permitiu - mais de cem anos depois - a criação de uma significativa Unidade de Conservação. Mas, e a sustentabilidade social dessa atividade? São pouquíssimas as informações disponíveis sobre tais atores sociais, que forneciam energia à cidade do Rio de Janeiro. Os carvoeiros em muito pouco se beneficiaram do seu trabalho, enquanto que muitos lucraram com ele. São, até hoje, invisibilizados do ponto de vista social e ignorados pela historiografia oficial. Dessa história, o único documento que nos restou foi o seu paleoterritório, hoje transformado em belo parque, que esconde, em meio a uma densa floresta, uma história de esquecimentos e desigualdades entre as pessoas que nela viveram e que dela se utilizaram.

\footnotetext{
2 Para se ter uma ideia deste montante de carvão, se ele fosse transportado em caminhões modernos de $10 \mathrm{~m}^{3}$, seriam necessários cerca de 6.800 caminhões.
} 


\section{À guisa de conclusăo: dimensôes materiais e năo-materiais da paisagem}

Finalmente, importa lembrar que as marcas da presença humana na paisagem são de naturezas muito diversas, podendo assumir contornos tanto materiais como imateriais. Este é o caso das figueiras centenárias (figura 3) da Mata Atlântica (Svorc e Oliveira, 2012), que passaremos a examinar.

Figura 3. Exemplar de uma figueira nativa (Ficus glabra) em meio a um trato de floresta secundária no Parque Nacional da Bocaina (SP)

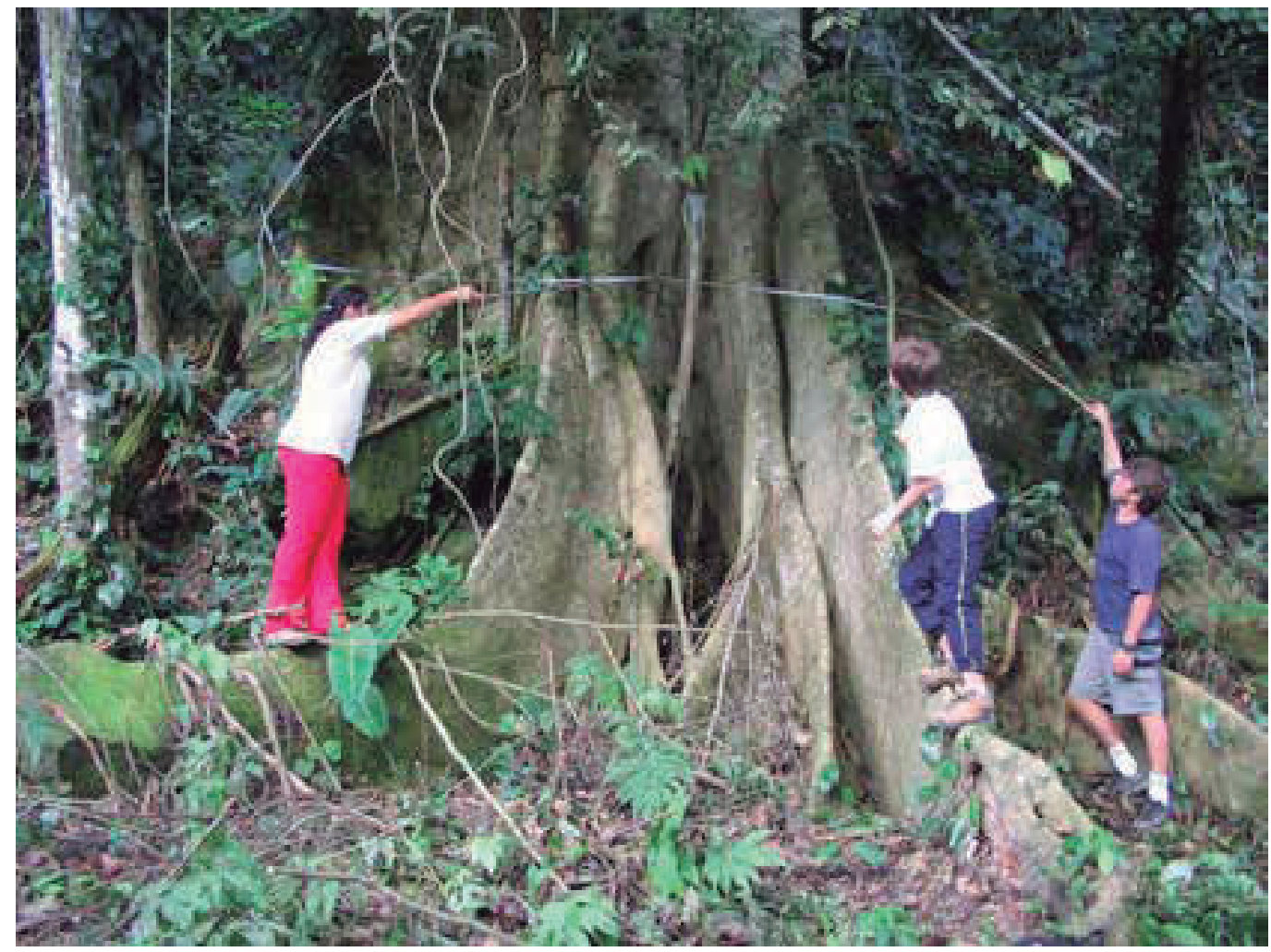

$\mathrm{Na}$ maioria das florestas secundárias do sudeste brasileiro, é notável a presença de figueiras de grande porte do gênero Ficus (Moraceae), preservadas da derrubada por razões culturais por populações tradicionais. Este tabu é ancorado tanto na tradição judaico-cristã quanto na afro-brasileira. Embora no Brasil existam cerca de cem espécies de figueiras nativas (Carauta, 1989), o gênero Ficus se destaca tanto pelo 
aspecto alimentar (representado fundamentalmente por Ficus carica, o figo comestível) quanto pela histórica tradição cultural, presente em muitas partes do mundo. Na costa da África, o iroko é considerado uma árvore sagrada pelos praticantes de candomblé (Verger, 1995). Na tradição afro-brasileira, as figueiras ocupam o lugar da espécie africana (Clorophora excelsa) para representar um deus-árvore: o iroko. No Novo Testamento, Jesus amaldiçoa uma figueira que não dá fruto. ${ }^{3}$

Assim, seja pela tradição judaico-cristã ou pela afro-brasileira, essa árvore é portadora de forte simbolismo e, por esses motivos, é preservada do corte por populações interioranas quando promovem derrubadas para a implantação de suas roças. Daí a constante presença destes exemplares de elevado porte, servindo como testemunho da história local. Constituem verdadeiros marcos na paisagem, e, em função disso, integram a toponímia de numerosos locais (como Mata da Figueira, Grota da Gameleira etc.). Mesmo em pastagens ou em áreas urbanizadas de diversas capitais brasileiras, frequentemente as árvores de maior porte preservadas são figueiras centenárias.

Esse traço cultural foi ao longo do tempo deixando marcas materiais na paisagem. Dentre elas destacam-se as alterações na composição, estrutura e funcionalidade dos ecossistemas. A manutenção pelas populações passadas desses exemplares de figueiras, ao longo dos ciclos de uso da paisagem, traz como resultantes aspectos ecológicos bastante concretos. Tais figueiras representam um recurso significativo para a fauna local, como o papagaio-chauá (Amazona rodocorytha), o tucano (Ramphastos vitellinus ariel), o araçarí (Selenidera maculirostris), o macaco-bugio (Alouatta fusca) e outros. Um contingente maior de animais, de hábito noturno, também faz uso desse recurso. A presença dessas árvores constitui, portanto, um importante elemento de atratividade da fauna dispersora de sementes. Em certa medida, a fauna silvestre depende desse tabu para o equilíbrio de suas populações.

O conceito de espécie-chave cultural, uma metáfora do conceito ecológico de espécie-chave, é relevante na questão da preservação das figueiras e em sua relação com a floresta circundante. Esse conceito se refere a espécies "cujo impacto na sua comunidade ou ecossistema é grande e de forma

\footnotetext{
3 "Evangelho de S. Mateus", 21: 18-22.
} 
desproporcional em relação à sua abundância” (Power, 1996). As figueiras centenárias da Mata Atlântica constituem, portanto, verdadeiros marcos culturais. Tal fato evoca o aspecto simbólico da paisagem, que pode expressar crenças, valores e mitos de uma população. Esta dimensão imaterial do paleoterritório, que se traduz em resultantes ecológicas concretas, traz à tona o largo espectro de ações de manejo dos ecossistemas por parte de populações pretéritas. Apesar de distintos históricos de ocupação, os motivos da preservação de tais exemplares é o mesmo e faz com que este tabu se espalhe por distintas populações tradicionais do sudeste brasileiro. A imponente presença dessas figueiras na Mata Atlântica contribui, de maneira clara, para contrapor-se "à ideia de natureza como externalidade ao humano" (Rehbein e Ross, 2010). Assim, ao mesmo tempo em que essas figueiras constituem marcos de um paleoterritório, representam também um verdadeiro semióforo (algo que não possui utilidade, mas representa o invisível no mundo do visível, ou pelo menos uma interpretação, um diálogo que se estabelece entre os dois mundos) (Arruda, 2013). Ou seja, a transmutação do ecossistema em paisagem e esta, em território.

Dessa forma, destaca-se a importância de se considerar o contexto social, nos quais os diferentes tempos determinam as atuais características das paisagens, milenarmente construídas, em cima de paleoterritórios. Os saberes das populações pretéritas sobre o ambiente envolvente são determinantes para a construção da funcionalidade, composição e estrutura dos atuais ecossistemas. A coevolução e interdependência na formação dessas paisagens culturais e a maneira com que elas se influenciam mutuamente tanto no aspecto simbólico como no material explicita a existência de uma floresta-cultura, que coexiste sem oposição a uma "floresta-natureza". Assim, a dimensão cultural da paisagem, explicitada no legado cultural e ecológico dos saberes e do trabalho de populações pretéritas, contribui para ampliar a compreensão de processos ecológicos hoje presentes, atuando ao mesmo tempo como um documento da forma de vida de segmentos de populações muitas vezes desconhecidos. Tais processos acontecem em um cenário de diversidade cultural (que envolve os conhecimentos e práticas de seus habitantes) e de diversidade biológica, que constituem um patrimônio de imenso valor potencial. A paisagem cultural passa a integrar, além da biodiversidade que lhe é inerente, a sociodiversidade, compondo assim um significativo corpus dos valores ambientais de uma determinada região. 


\section{Referências}

ARRUDA, G. "Monumentos, semióforos e natureza nas fronteiras". In (org.). Natureza, fronteiras e territórios. 2 ed. Londrina: EDUEL, 2013, pp. 1-42.

BEZERRA, R. V. M. Sedimentos de uma história: ausência de um passado presente em uma floresta do Rio de Janeiro (dissertação). PUC-Rio, 2013.

CARAUTA, J. P. P."Ficus (Moraceae) no Brasil: conservação e taxonomia”. Albertoa, v. 2, pp. 1-365, Rio de Janeiro, 1989.

CLEMENT C. R. et al. "Agrobiodiversity in Amazonia and its relationships with dark earths". In LEHMANN J. et al. (eds.). Amazonian Dark Earths: Origin, Properties, Management. Dordrecht: Kluwer Academic Publishers, 2003, pp. 159-78.

COLACIOS, R. D. "Os usos e abusos das ciências naturais pela história ambiental: interdisciplinaridade, diagnósticos e reflexões”. HALAC Revista de la SOLCHA, v. 3, pp. 180-207, Belo Horizonte, set. 2013.

FRAGA, J. S. e OLIVEIRA, R. R. "Social metabolism, cultural landscape, and social invisibility in the forests of Rio de Janeiro". In CANEVACCI, M. (org.). Polyphonic Anthropology: theoretical and empirical cross-cultural fieldwork. Rijeka: InTech, 2012, pp. 139-56.

FREIRE, J. M. Florística e fitossociologia do estrato arbustivo e arbóreo de um remanescente de floresta urbana no Parque Estadual da Pedra Branca, Rio de Janeiro-RJ (tese). UFRRJ, 2010.

NAVEH, Z. e LIEBERMAN, A. Landscape ecology: theory and application. Nova Iorque: Springer-Verlag, 1994.

OLIVEIRA, F. C. et al. "Avanços nas pesquisas etnobotânicas no Brasil". Acta Botanica Brasilica, v. 23, pp. 590-605, 2009.

OLIVEIRA, R. R. "Environmental history, traditional populations, and paleo-territories in the Brazilian Atlantic Coastal Forest". Global Environment, v. 1, pp. 176-91, 2008.

e FRAGA, J. S. "Metabolismo social de uma floresta e de uma cidade: paisagem, carvoeiros e invisibilidade social no Rio de Janeiro dos séculos XIX e XX”. GeoPuc, v. 4, pp. 1-18, Rio de Janeiro, 2012. 
OLSON, S. D. "Firewood and charcoal in Classical Athens". Hesperia, v. 60, n. 3, pp. 411-20, Princeton, 1991.

PÁDUA, J. A. "As bases teóricas da história ambiental". Estudos Avançados, v. 24, n. 68, pp. 81-101, São Paulo, 2010.

POWER, M. "Challenges in the quest for keystones". Bioscience, v. 46, $\mathrm{n}$. 8, pp. 609-20, Washington, 1996.

REHBEIN, M. O. e ROSS, J. L. S. "Ambiente; urbano; impacto - impacto ambiental urbano: revisões e construções de significados". GEOUSP: Espaço e Tempo, v. 27, pp. 95-112, São Paulo, 2010.

RIBEIRO, M.B.N. et al. "Anthropogenic landscape in Southeastern Amazonia: contemporary impacts of low-intensity harvesting and dispersal of Brazil nuts by the Kayapó indigenous people”. PLoS ONE, v. 9, n. 7, pp. 102-87, 2014.

SANTOS, M. A. Natureza do espaço: técnica e tempo, razão e emoção. 4 ed. São Paulo: Editora da Universidade de São Paulo, 2008.

SHEPARD Jr., G. H. e RAMIREZ, H. "'Made in Brazil': human dispersal of the Brazil nut (Bertholletia excelsa, Lecythidaceae) in ancient Amazonia”. Economic Botany, v. 65, n. 1, pp. 44-65, 2011.

SVORC, R. C. P. F. e OLIVEIRA, R. R. "Uma dimensão cultural da paisagem: biogeografia e história ambiental das figueiras centenárias da Mata Atlântica”. GEOUSP: Espaço e Tempo, v. 32, pp. 140-60, São Paulo, 2012.

TELLO, E. et al. "Energy balance and land use: the making of an agrarian landscape from the vantage point of social metabolism (the Catalan Vallès County in 1860/1870)". In AGNOLETTI, M. (ed.). The conservation of cultural landscapes. Wallingford: CAB International, 2012, pp. 42-56.

VERGER, P. Ewé: o uso das plantas na sociedade iorubá. São Paulo: Companhia das Letras, 1995.

WILLIAMS, R. Cultura e materialismo. São Paulo: Editora UNESP, 2011.

WORSTER, D. "Para fazer história ambiental". Estudos Históricos, v. 4, n. 8, pp. 198-215, Rio de Janeiro, 1991. 


\title{
CAPÍTUL0 II
}

\section{Agroecologia e as práticas tradicionais: reconhecendo os saberes ancestrais}

\author{
Mariana Martins da Costa Quinteiro \\ Karla Beatriz Lopes Baldini
}

"Mês de agosto é tempo de queimada

Vou lá prá roça preparar o aceiro

Faísca pula quem nem burro brabo

E faz estrada lá na capoeira

A terra é a mãe, isso não é segredo

O que se planta esse chão nos dá Uma promessa a São Miguel Arcanjo Prá mandar chuva pro milho brotar...

Passou setembro, outubro já chegou

Já vejo o milho brotando no chão

Tapando a terra feito manto verde

Prá esperança do meu coração

Mês de dezembro, vem as boas novas

A roça toda já se embonecou

Uma oração agradecendo a Deus

E comer o fruto que já madurou... Mês de janeiro, comer milho assado Mingau e angu no mês de fevereiro

Na palha verde enrolar pamonha E comer cuscuz durante o ano inteiro Quando é chegado o tempo da colheita

Quebra de milho, grande mutirão

A vida veste sua roupa nova Prá ir no baile lá no casarão...” 


\section{Agroecologia e o contexto local}

A agroecologia é a ciência que apresenta uma série de princípios, conceitos e metodologias para estudar, analisar, dirigir, desenhar e avaliar agroecossistemas, com o propósito de permitir a implantação e o desenvolvimento de estilos de agricultura envolvidos com contextos socioecológicos específicos. Não se trata, portanto, de um modelo nem uma forma ou estilo particular de agricultura, mas de um referencial teórico, que ganha caráter concreto quando aplicado à realidade socioeconômica e ecológica local (Altiere, 2000).

Entretanto, o objetivo da ciência aplicada à agricultura ao longo das últimas décadas tem sido a substituição dos processos ecológicos naturais por um maior controle do ambiente, modo pelo qual se busca diminuir as variáveis dentro dos fatores de produção que afetam as plantas (ou animais) de interesse direto (Michon e De Foresta, 1997). Neste processo, a tomada de decisão que gera os sistemas de produção agrícola e as políticas que os sustentam vem desconsiderando o necessário diálogo socioambiental, criando um sistema técnico quase que totalmente ligado a uma fonte externa de informação.

Dessa forma, deve ser questionada a forma de transferências de tecnologia no padrão unidirecional, no sentido dos que "sabem" para os que "não sabem": emissão (pesquisa) $\rightarrow$ transmissão (extensão) $\rightarrow$ recepção (agricultores) (Vivan, 2000). Esse modelo, fortemente contestado nos anos 1980, persistiu dentro de boa parte dos serviços de pesquisa e extensão, os quais têm dificuldades de concretizar a intercessão dos saberes popular e técnico. Algumas perguntas como: "Qual é a fonte de cada um desses saberes?"; "Quais são as reais convergências e divergências entre eles?" e "O que elas significam para o agroecossistema?", devem ser respondidas com o objetivo de identificar a origem das informações que são transformadas em decisão de intervenção no agroecossistema pelos agricultores.

Mais do que uma questão puramente de técnicas agrícolas, há evidências de que o modelo adotado atualmente provoca desarranjos nas camadas superiores da cultura. São distorções que se expressam na organização social, nas manifestações culturais, nos hábitos alimentares e até mesmo no estado psicológico. 
Em uma oposição virtuosa, os sistemas agrícolas gerados pelo conhecimento nativo são, geralmente, formas sofisticadas de agricultura ecológica, finamente ajustadas às condições ambientais específicas (Adams, 2000). Essas experiências são fundamentais para referendar a (re)construção do conhecimento agroecológico em diferentes regiões do país. É emergente a contextualização do rural como uma "questão ambiental", integrando uma variedade de grupos sociais a conflitos em torno da apropriação territorial e de "recursos naturais" (Diegues, 2000; Gerhardt, 2002; Little, 2002). Assim, o resgate de conhecimentos agrícolas oriundos das populações tradicionais, os exemplos de manejo sustentável dos recursos naturais e os sistemas de produção com base nos princípios da agroecologia devem ser incentivados.

Nesse sentido, as chamadas etnociências vêm corroborar com o diálogo entre os saberes acadêmico/científico e popular/tradicional (Quinteiro et al., 2013). Estudos nessa área deveriam se articular mais com as propostas de conservação e manejo sustentável dos recursos, desde sua fase de campo, para avaliação do que o estudo tem a oferecer na prática (Araújo, 1996; Quinteiro e Moraes, 2012). A agroecologia se constrói apoiada na valorização dos recursos locais e nas práticas e métodos tradicionais de manejo produtivo dos ecossistemas, e sua evolução como ciência se dá quando são criadas condições favoráveis para o diálogo e a troca de experiências e saberes.

$\mathrm{Na}$ busca por relatos e experiências sobre "agroecologia e saberes tradicionais/locais", sistematizaram-se alguns artigos de diferentes regiões do Brasil para efeito comparativo. Esses dados são apresentados em tabelas ao longo do texto para uma melhor visualização. O capítulo traz uma revisão dos conceitos e práticas em agroecologia, buscando a essência do conhecimento praticado por diferentes grupos como indígenas e rurais na região Norte, Sudeste e Sul do Brasil.

\section{Sabedorias ancestrais dos cultivos agrícolas em agrofloresta}

Leff (2000) afirma que o conhecimento empírico das comunidades é capaz de otimizar a produtividade primária dos ciclos biológicos, gerando tecnologias apropriadas para transformar estes recursos de modo eficiente. Elevando-se a produtividade ecotecnológica dos processos produtivos e 
evitando-se os efeitos ecodestrutivos e as deseconomias externas geradas por processos tecnológicos altamente capitalizados, o autor sugere que busquemos a lógica de uma racionalidade produtiva alternativa.

O uso da terra envolvendo consórcios entre espécies arbóreas, culturas agrícolas e animais é uma prática milenar, utilizada por populações rurais em diferentes lugares do mundo. A história mostra que os Sistemas Agroflorestais (SAF’s) não são uma criação meramente científica, mas demonstram o reconhecimento, por parte dos setores acadêmico e político, da importância de uma prática comum entre muitas comunidades tradicionais; o papel inicial da ciência foi classificá-los e sistematizá-los, no que se refere à natureza dos componentes presentes no sistema (Nair, 1993).

No Brasil, como ressalta Arruda (1997), as florestas tropicais abrigam comunidades humanas de grande diversidade sociocultural, que desenvolveram estilos de vida relacionados a ambientes naturais específicos. Com suas visões de mundo particulares, conhecimento extenso e minucioso dos processos naturais e que estabelecem relações com o mundo natural, essas comunidades são distintas das que prevalecem nas sociedades urbano-industriais.

Apesar desse contexto histórico, os sistemas agroflorestais não são adotados em larga escala no Brasil, sendo um dos motivos apontados a dificuldade das comunidades atuais para compreender e validar os complexos mecanismos e benefícios biológicos decorrentes dessa prática da forma como é transmitida pelo conhecimento acadêmico (Sinclair e Walker, 1999). Para esses autores, a tradição florestal parece não fazer parte de algumas culturas humanas modernas, podendo-se apontar uma enorme perda no conhecimento relativo à prática agroflorestal nessas comunidades, o que pode ser mitigado pela união entre diferentes ciências, no contexto da complexidade ambiental discutida por Moram (1994).

Dentro desse contexto, Quinteiro et al. (2009) propõem um modelo em que o Manejo Florestal Comunitário pode representar um caminho de articulação entre a etnobotânica, o diagnóstico ambiental participativo e os Sistemas Agroflorestais, com benefícios para a comunidade estudada, o setor florestal da região e o patrimônio cultural local. 


\section{Os cultivos em roças}

O cultivo de plantas para variados fins é praticado desde tempos remotos, quando o homem passou da sua condição nômade (coletor-caçador) à permanência por mais tempo numa área. O sedentarismo fez com que buscasse recursos mais duradouros para a sua sobrevivência, desenvolvendo, assim, a domesticação de espécies, observada no cultivo de plantas e na criação de animais. Leonel (2000) cita que a dependência da agricultura requer um trabalho mais intenso e, ao mesmo tempo, permite um modo de vida mais sedentário. $\mathrm{O}$ aumento do trabalho envolvido no cultivo se dá porque as roças devem ser plantadas, cuidadas e colhidas. Entretanto, o alimento se torna disponível numa maior concentração e abundância locais, podendo ainda serem escolhidas características do vegetal desejáveis e replicáveis em cruzamentos intencionais.

Nessa nova relação com as plantas, o homem foi desenvolvendo técnicas de cultivo que permitissem obter recursos para otimizar a produção, como o uso do fogo, o pousio, o consórcio e a rotação de culturas nas unidades produtivas itinerantes chamadas de "roça de coivara", "de corte e queima" ou "de toco" (slash and burn). Essa forma de cultivo constitui uma tradição milenar da maioria das populações indígenas, sendo adaptada por outras populações na colonização. Essa "agricultura de pousio" é baseada no corte e queima da vegetação, em que o agricultor ordena a rotação das áreas de roça a fim de permitir o restabelecimento da fertilidade do solo (Altieri, 2000).

Um ponto muito discutido entre os pesquisadores sobre essa forma de agricultura é o uso do fogo para a renovação do solo. Felipim et al. (2004) citam alguns trabalhos feitos no Brasil sobre a importância do uso do fogo como principal agente no aumento imediato da fertilidade do solo, no rebrotamento de algumas espécies vegetais em determinados biomas e no controle da acidez do solo. Ademais, Coutinho (1990) discute que as queimadas em rodízio, em parcelas pequenas e com regimes próprios, reduziriam os riscos de grandes incêndios acidentais, permitiriam às plantas completar seus ciclos biológicos, acelerariam a ciclagem dos nutrientes minerais e aumentariam a produtividade dos ecossistemas, além de suprir os animais com alimentos durante os difíceis meses de seca. 
Os autores ressaltam, entretanto, que a viabilidade do sistema esta relacionada com diversos fatores como, baixa densidade demográfica, abundância de terras e condições de solo e clima.

Em relação aos cultivos de "roça" no Brasil, o milho e o feijão, em diferentes variedades, são as principais culturas em todas as regiões. Para exemplificar sua situação no Brasil, foram sistematizados alguns trabalhos feitos em diferentes regiões do país (tabela 1). De acordo com cada região, observa-se que outros cultivares agrícolas são encontrados em consórcio com essas duas culturas.

Dados da Embrapa (2004) apontam que a agricultura familiar é responsável pela produção de $49 \%$ do milho e $67 \%$ de todo o feijão no Brasil. Com uma tipologia de agricultores familiares diversificados, essa produção é oriunda desde a agricultura de subsistência até a familiar empresarial.

Naves et al. (2004) afirmam que o cultivo do milho tem se destacado entre as atividades de pequenos produtores, uma vez que o grão é utilizado na alimentação animal (aves e suínos, principalmente), representando a maior parte do consumo desse cereal no Brasil e no mundo. Ele constitui um alimento especialmente importante em regiões com maior cultura tradicional, como é o caso do nordeste brasileiro, onde representa uma das principais fontes de energia diária para grande parte da população do semiárido. 


\section{Tabela 1. Principais cultivos de subsistência no Brasil por pequenos agricultores}

\begin{tabular}{|c|c|c|c|c|}
\hline $\begin{array}{l}\text { Local/ } \\
\text { Autor/Ano }\end{array}$ & $\begin{array}{r}\text { Grupo } \\
\text { social }\end{array}$ & Cultivos & $\begin{array}{l}\text { Forma de } \\
\text { cultivo }\end{array}$ & Observação \\
\hline $\begin{array}{l}\text { SP (litoral) } \\
\text { (Felipim, 2001) }\end{array}$ & Indígena & $\begin{array}{l}\text { Milho (nove va- } \\
\text { riedades), abó- } \\
\text { bora, mandioca, } \\
\text { feijão (duas } \\
\text { variedades) }\end{array}$ & Consorciado & $\begin{array}{l}\text { Diminuição de } \\
\text { terra } \\
\text { Aumento do } \\
\text { desmatamento } \\
\text { Ritual agrário }\end{array}$ \\
\hline $\begin{array}{l}\text { AM } \\
\text { (Pinto e } \\
\text { Garavello, } \\
2002 \text { ) }\end{array}$ & Indígena & $\begin{array}{l}\text { Milho e outras } \\
\text { plantas anuais }\end{array}$ & Consorciado & Ritual agrário \\
\hline $\begin{array}{l}\text { AM } \\
\text { (Murrieta e } \\
\text { Dufour, 2004) }\end{array}$ & Ribeirinhos & Milho e feijão & Consorciado & $\begin{array}{l}\text { Alimentação dos } \\
\text { animais e venda }\end{array}$ \\
\hline $\begin{array}{l}\text { AM } \\
\text { (Adams, 2005) }\end{array}$ & Ribeirinhos & $\begin{array}{l}\text { Mandioca, } \\
\text { milho, feijão e } \\
\text { curcubitaceaes }\end{array}$ & $\begin{array}{l}\text { Consorciado } \\
\text { Sabem téc- } \\
\text { nicas, nem } \\
\text { sempre usam }\end{array}$ & $\begin{array}{l}\text { Desafio: es- } \\
\text { coamento dos } \\
\text { produtos. Prefe- } \\
\text { rência por trans- } \\
\text { porte de alimen- } \\
\text { tos "secos" }\end{array}$ \\
\hline $\begin{array}{l}\text { RS } \\
\text { (Perroto, 2007) }\end{array}$ & Rural & $\begin{array}{l}\text { Feijão, aipim, } \\
\text { milho }\end{array}$ & $\begin{array}{l}\text { Não consor- } \\
\text { ciado e con- } \\
\text { sorciado }\end{array}$ & - \\
\hline $\begin{array}{l}\text { Rio } \\
\text { Amazonas } \\
\text { (Maciel e } \\
\text { Souza, 2009) }\end{array}$ & Ribeirinhos & $\begin{array}{l}\text { Mandioca, jeri- } \\
\text { mum, maxixe, } \\
\text { milho, melancia } \\
\text { e pimentas }\end{array}$ & Consorciado & - \\
\hline $\begin{array}{l}\text { MG } \\
\text { (Machado et } \\
\text { al., 2010) }\end{array}$ & Rural & $\begin{array}{l}\text { Milho, feijão, } \\
\text { hortaliças e er- } \\
\text { vas medicinais }\end{array}$ & $\begin{array}{l}\text { Consorciado } \\
\text { (plantas pere- } \\
\text { nes, semi-pe- } \\
\text { renes e anuais) }\end{array}$ & $\begin{array}{l}\text { Recurso de fácil } \\
\text { acesso }\end{array}$ \\
\hline $\begin{array}{l}\text { Serra da Man- } \\
\text { tiqueira } \\
\text { (RJ/MG) } \\
\text { (Quinteiro, } \\
\text { 2012) }\end{array}$ & Sitiantes & $\begin{array}{l}\text { Milho, feijão, } \\
\text { abóbora, batata }\end{array}$ & $\begin{array}{l}\text { Não consor- } \\
\text { ciado e con- } \\
\text { sorciado }\end{array}$ & $\begin{array}{l}\text { Passado: Maior } \\
\text { cultivo, diminuído } \\
\text { por mudanças nas } \\
\text { leis ambientais }\end{array}$ \\
\hline
\end{tabular}




\section{Tempo para colher e tempo para descansar}

O solo também tem um tempo específico para ser utilizado segundo diferentes tradições, devendo depois ser deixado em "pousio" e outras terras serem utilizadas, segundo "rotação" específica. O conceito de "pousio" é definido como uma forma de agricultura marcada pela rotação de pequenas áreas de cultivos ( 3 a 5 hectares), alternando períodos curtos ( 2 a 4 anos) com períodos maiores de descanso (10 a 12 anos) (Silva, 1996).

Durante esse tempo de "descanso", ocorre o desenvolvimento gradual de uma vegetação de capoeira com a incorporação de nutrientes, podendo chegar à formação de uma floresta secundária mais avançada (Bertolino e Bertolino, 2010). A capoeira que se desenvolve na área de pousio tem a capacidade de ampliar a regeneração do solo de forma natural, gradual e espontânea. Há necessidade de a terra ficar parada por um tempo para que ocorram, naturalmente, modificações nas propriedades físicas e químicas do solo, essencial para a sustentabilidade do sistema.

No processo de pousio, geralmente, o agricultor não deixa o solo totalmente exposto. Deixa-se a palhada (sobras da cultura, como folhas e galhos) da plantação anterior ou há o plantio de algum gênero destinado à adubação verde. Adams (2000), em trabalho com ribeirinhos no Amazonas, cita o plantio do capim-murim (Paspalum fasciculatum) como forma de manejo das roças em pousio, para proteção do solo. Algumas referências ao tempo de pousio são encontradas na tabela 2 :

Tabela 2. Tempo de pousio de roças tradicionais no Brasil

\begin{tabular}{|l|c|}
\hline Estado/Autor/Ano & Tempo de pousio \\
\hline AM- Adams (2000) & 2 a 3 anos \\
\hline AM - Pinto e Garavello (2002) & 2 a 3 anos \\
\hline AM - Maciel e Souza (2009) & Depois do $2 .^{\circ}$ ano de cultivo \\
\hline RJ / MG - Quinteiro (2012) & $\begin{array}{c}\text { Depois do } 2 .^{\circ} \text { ou } 3 .^{\circ} \text { ano } \\
\text { Repouso }-1 \text { a } 5 \text { anos }\end{array}$ \\
\hline
\end{tabular}


Adams et al. (2005) discutem que as formas de cultivo itinerante surgiram de maneira independente em vários pontos das florestas tropicais ao redor do mundo e se mostraram uma forma de agricultura sustentável e muito adaptada às condições tropicais. A área relativamente pequena, desmatada para o cultivo, e o reduzido tempo pelo qual era usada permitiam uma regeneração total em pouco tempo, sem comprometer a paisagem natural e devolvendo a fertilidade do solo naturalmente.

\section{A origem das sementes}

Desde muito tempo, diversas gerações de agricultores têm selecionado e conservado sementes de diferentes cultivares, gerando e mantendo, assim, variedades que possuem uma boa adaptação ao lugar de origem. Recursos esses valiosos por representarem um produto da interação evolutiva entre um vegetal e seu meio, passando pelo conhecimento humano, desde tempos imemoriais. A conservação dessas sementes em seus locais de ocorrência - in situ - é de extrema importância contra a erosão dos recursos genéticos e a perda da biodiversidade, e para a manutenção da soberania alimentar local, contribuindo para a preservação do patrimônio histórico-cultural de grupos locais, em suas dimensões material e imaterial. Entretanto, essas sementes vêm perdendo o uso e espaço, pelo pacote tecnológico de produção trazido pela Revolução Verde, a partir da década de 1960 e, mais atualmente, pelos transgênicos.

Chamadas de sementes "crioulas" ou "locais", são definidas como aquelas melhoradas e adaptadas por agricultores, com seus próprios métodos e sistemas de manejo, desde que a agricultura se iniciou, há mais de 10 mil anos (Correa e Weid, 2006). Garcia (2004) ressalta que, em cada contexto regional, a semente "crioula" assume uma dimensão diferente; enquanto no Sul do país a sua produção representa autonomia e resgate da tradição, no Nordeste ela é, sobretudo, uma questão de sobrevivência. Além disso, o pequeno agricultor tem mais condições de enfrentar uma seca prolongada, se cultiva e seleciona variedades locais e tradicionais melhoradas em sua adaptação ao meio.

Um ponto que chama atenção na conservação e uso das sementes crioulas é que, até agosto de 2003, a legislação em vigor no Brasil criminalizava seu uso. Graças à pressão exercida por grupos de pequenos 
agricultores, movimentos sociais e associações, em 5 de agosto de 2003, foi aprovada a Lei n. $^{\circ} 10.711$ que reconhece a existência desse tipo de semente e deixa a porta aberta para a sua possível comercialização.

$\mathrm{Na}$ legislação atual sobre sementes, entende-se por cultivar "local", "tradicional" ou "crioulo" a variedade desenvolvida, adaptada ou produzida por agricultores familiares, assentados da reforma agrária ou indígenas, com características fenotípicas bem determinadas e reconhecidas pelas respectivas comunidades (Santilli, 2012). A critério do Ministério da Agricultura, Pecuária e Abastecimento (MAPA), são considerados também os descritores socioculturais e ambientais dessas variedades, grupos humanos que a utilizam e a caracterizem como substancialmente diferentes dos cultivares comerciais (Santilli, 2012). Sendo conhecidas ainda como "sementes da paixão" e "sementes da biodiversidade", os critérios reais que as distinguem das comerciais ainda não estão bem definidos, fazendo-se essencial que a discussão dessas diferenças seja validada pelos agricultores que as manejam (Santilli, 2012).

$\mathrm{O}$ uso de variedades locais possui diversas outras vantagens ligadas à sustentabilidade da produção, como resistência a doenças, pragas e desequilíbrios climáticos, podendo as sementes serem armazenadas para as safras seguintes, o que diminui o custo de produção (Carpentiere-Pipolo et al., 2010). Constitui, assim, uma alternativa para a sustentabilidade dos pequenos agricultores, que promovem seu melhoramento através de grande conhecimento acerca desse recurso (Abreu et al., 2007). O ganho ambiental também é superior, uma vez que o uso de variedades crioulas, adaptadas localmente, mantêm a diversidade genética das espécies (Cecarelli, 1994).

De uma maneira geral, o pequeno produtor que cultiva sua roça dentro do sistema tradicional tem por objetivo a subsistência, ou seja, a produção para consumo familiar e a manutenção das sementes para o próximo período de plantio. A venda de algum excedente, quando ocorre, fica quase sempre abaixo dos $30 \%$ do valor bruto da produção (IBGE, 2000). Em função de sua finalidade eminentemente de subsistência, a produção da roça não deveria, a rigor, ser avaliada do ponto de vista estritamente econômico, dado o seu forte conteúdo socioeconômico e até político, sobretudo em termos de ocupação produtiva e segurança alimentar (Varella, 2003). 
A baixa dependência de insumo comercial, juntamente com o uso do conhecimento e da cultura da população local, está inserida dentro da agricultura sustentável, com base agroecológica. Assim, pesquisas sobre a fonte de sementes para plantio podem ser um bom indicativo da perda ou manutenção da atividade agrícola tradicional de determinada comunidade. Pelo exposto, torna-se fundamental o repasse e a conscientização da importância da manutenção local de sementes crioulas e de sua manipulação.

\section{Mapeando as épocas boas para o plantio}

A observação de diferentes trabalhos com comunidades tradicionais tem nos mostrado que a ligação entre estas e os períodos naturais ocorre de forma bem peculiar. A relação de "tempo oportuno" para diversas práticas agrícolas, como plantio, rega, poda, colheita, é verificada como uma ciência precisa, porém específica entre determinados grupos humanos e seu ambiente. Incapaz, portanto, de ser reproduzida fielmente de um lugar para outro, mas preciosa em seu contexto local.

Nesse sentido, são consideradas "épocas do ano", como períodos de seca e chuva, frequentemente referidos como "meses com e sem ' $r$ "', luas específicas, horas do dia e outros tantos "momentos" para que um dado manejo seja feito na plantação ou no solo.
Outro elemento importante na escolha dos períodos de plantio é o conhecimento do céu. Os povos antigos, inclusive os índios brasi- leiros já relacionavam fenômenos celestes com os ciclos naturais, determinando assim épocas de plantio, caça, pesca e seus rituais. Encontramos registros desses conhecimentos em vestígios arque- ológicos (pinturas rupestres) e na tradição oral dos povos indíge- nas contemporâneos (Fonseca et al., 2007).

Afonso (2009) discute que, além da orientação geográfica, um dos principais objetivos práticos da astronomia indígena era sua utilização na agricultura. Muitas etnias indígenas associavam as estações do ano e as fases da lua com a biodiversidade local, para determinarem a época de plantio e da colheita, bem como para a melhoria da produção e o controle natural das pragas. Eles consideram que a melhor época para certas ati- 
vidades, tais como a caça, o plantio e o corte de madeira, é perto da lua nova, pois perto da lua cheia os animais se tornam mais agitados, devido ao aumento de luminosidade, e as plantas possuem mais seiva (Afonso, 2009). O autor cita, como exemplo, a incidência dos percevejos que atacam a lavoura na lua cheia e o plantio principal do milho que ocorre, geralmente, na primeira lua minguante de agosto.

De acordo com Jafelice (2002), a psicogênese filogenética de concepções que atualmente associamos à astronomia - como perceber regularidades espaciais e temporais ou relações entre fenômenos terrestres e celestes foi sendo realizada enquanto mudanças evolutivas iam transformando nossos ancestrais em membros de nossa espécie. Heranças dessas origens exercitam o imaginário inconsciente e ativam nas pessoas inúmeros simbolismos relacionados ao céu. Essa pode ser uma via interessante para exemplificar diante da população outra forma de construção que não a puramente científica. Nesse sentido, Fonseca et al. (2007) acreditam que a etnoastronomia e a mitologia que a envolve podem conduzir a descobertas importantes sobre diferentes formas de estar no mundo, diferentes identidades, concepções e práticas diversas, apesar de membros de uma única e mesma humanidade, regidos por fenômenos naturais comuns.

Em 2005, a United Nations Education, Scientific and Cultural Organization - UNESCO - aprovou uma iniciativa temática para "identificar, salvaguardar e promover propriedades culturais conectadas com a Astronomia” (UNESCO, 2010).

Segundo Lima e Figueiroa (2010), os primeiros estudos quantitativos sobre astronomia cultural apareceram nas últimas décadas do século XIX, quando surgiu também o termo "etnoastronomia". Os autores pontuam que, na década de 1970, surgem as primeiras publicações específicas sobre a arqueo e etnoastronomia, já com um caráter interdisciplinar, onde se destacam os trabalhos de Anthony F. Aveni, H. Hartung, Johanna Broda, entre outros; em 1982, é publicado um livro importante: Ethnoastronomy and Archaeoastronomy in the American Tropics, uma coletânea de trabalhos de pesquisadores internacionais apresentados em um congresso na New York Academy of Sciences. No Brasil, um trabalho pioneiro sobre etnoastronomia brasileira foi o artigo "Chuvas e Constelações - Calendário econômico dos Índios Desâna” (Ribeiro e Kenhíri, 1987), que traz um índio desana como coautor. 
Alguns trabalhos que relacionam épocas ideais ou restritas para a plantação em relação às luas ou a determinadas épocas do ano, em diferentes partes do Brasil, são aqui referenciados:

1. Felipim (2001) comenta que a produção do milho e do feijão entre os Guarani Mbyá era baseada na roça de coivara, próximas às casas, as quais são iniciadas no mês de abril, para depois serem realizados os plantios em junho/julho e a colheita no fim do verão, em fevereiro/março. A autora comenta ainda que, após o plantio de uma variedade, a próxima só podia ser semeada na lua minguante, pois, para eles, plantar diferentes cultivares em uma mesma área de roça ajuda a "segurar o casamento". O período de maior concentração de trabalhos envolvendo os recursos vegetais foi reportado como sendo a época de lua minguante, quando se realizam coletas de materiais para construção, artesanato e agricultura, principalmente a colheita de sementes destinadas a serem plantadas no próximo ano. Além disso, desaconselham a lua nova para o plantio de raízes e grãos.

2. Perotto (2007) observou, em uma comunidade de sitiantes tradicionais no Rio Grande do Sul que, na conformação dos espaços das propriedades rurais na roça, o feijão, o aipim e o milho são gêneros indispensáveis, plantados preferencialmente na época do cedo (minguante de primavera).

3. Machado et al. (2010) observaram que as fases da lua são seguidas pela maior parte dos sitiantes, em uma região de Minas Gerais, no plantio de suas roças e hortas, afirmando existir relação clara entre os tipos de plantas, a produção, o ataque de pragas e a época de plantio seguindo o calendário lunar. Os autores comentam que houve um relato de que quando se planta depois da lua cheia, não dá raiz ou "cabeça"; se plantar cenoura e alho na lua nova a raiz "não sai direito"; que a alface e o quiabo têm que ser plantados na lua nova, e abóbora tem que ser depois da cheia. Afirmam que, para essa comunidade, a orientação fundamental deve se dar não na hora de colher, mas na época de plantar. 
4. Quinteiro (2012), em estudo a sitiantes tradicionais na Serra da Mantiqueira (RJ/MG), cita que as "verduras", também denominadas de "hortaliças", "plantas de horta" e "folhagens", receberam indicações para serem plantadas nos meses com pouca ou sem chuva. Já os "vegetais que crescem para debaixo da terra", chamados localmente de "tubérculos", "plantas de chão" e "plantas de terra", foram descritos como sendo ideal de serem plantados na época das chuvas, especialmente no início, nos meses de setembro e outubro, sendo a colheita realizada na época das secas. Grande destaque foi dado para a época de plantação do milho e do feijão, gêneros mais representativos das roças nessa comunidade, os quais foram indicados para serem semeados nos meses de setembro, outubro e novembro.

\section{A atividade agrícola tradicional e a conservaçăo da biodiversidade local}

O modelo de conservação ambiental no Brasil se confronta, de inúmeras formas, com as práticas agrícolas tradicionais, o que vem causando grande ameaça aos saberes agroecológicos locais. Ao ignorar o potencial conservacionista dos segmentos culturalmente diferenciados, que historicamente conservaram a qualidade das áreas que ocupam, a política ambiental vigente tem desprezado possivelmente uma das únicas vias adequadas para alcançar os objetivos a que se propõe. Essa via é a da inclusão da perspectiva das populações rurais em nosso conceito de conservação e o investimento no reconhecimento de sua identidade, na valorização de seu saber, na melhoria de suas condições de vida, na garantia de sua participação na construção de uma política de conservação, da qual também sejam beneficiários. Como comenta Pretty (1994), a noção de que profissionais instruídos talvez tenham coisas para aprender dos não-alfabetizados é ainda grande heresia para alguns, o que deve ser superado.

A partir de um diagnóstico preliminar da cultura tradicional da roça, é possível identificar aspectos favoráveis e problemas da comunidade, determinantes, inclusive, da expansão das atividades agrícolas, bem como as suas aptidões e necessidades, demandas reais para cursos de capacitação, atividades de pesquisa, desenvolvimento e para projetos de infraestrutura (Machado et al., 2010). É nesta integração de espaços com lógicas 
bastante distintas que se pode "assegurar a identidade do grupo que experimenta uma consciência de si na relação de alteridade com o de fora" (Carneiro, 1998).

Independentemente do quão sustentáveis sejam as práticas de agricultores locais, o conhecimento deles é uma importante fonte de informações; seus conceitos e pontos de vista são algo que os pesquisadores em agroecologia devem considerar (Gliessman, 2000). Por essa razão - e por considerarmos que a premissa básica é o conhecimento local e o saber dos agricultores como ponto chave inicial de qualquer movimento em direção à sustentabilidade -, é que se mostra fundamental esse diagnóstico etnoecológico.

As incongruências entre a legislação e os valores tradicionais, ou mesmo entre as leis que dizem respeito à conservação do meio ambiente $\mathrm{e}$ às relativas aos direitos humanos, evidenciam a ausência de participação comunitária para elaboração e gestão dos instrumentos da conservação ambiental. No caso das práticas agrícolas, essas incongruências se relacionam, principalmente, às interdições na prática das queimadas, à retirada de algumas espécies, ao uso de áreas especificas para plantio, à abertura de novas áreas na mata e, por vezes, ao plantio de cultivares exóticos. Ficam assim dificultadas ou mesmo impedidas as práticas tradicionais outrora citadas, como a roça de coivara, baseada no corte/queima, o pousio e a rotação das culturas agrícolas.

Posteriormente, a colheita e retirada de algumas espécies por essas comunidades manejadas tornam-se proibidas ou sujeitas a processos morosos de permissão por profissionais da conservação. $O$ resultado, salvo algumas exceções, é a diminuição da autonomia agroecológica das comunidades tradicionais, a diminuição da soberania sobre as sementes crioulas, a mudança de hábitos alimentares e o desinteresse pelo manejo tradicional dos recursos naturais. A maioria das instituições envolvidas com a proteção da biodiversidade desconsidera os aspectos socioambientais, atuando mais sob a forma de multas e repressões do que com educação e envolvimento com a sabedoria das comunidades locais.

Essa atitude, além de inviabilizar o processo produtivo das principais culturas, causa desconforto entre os agricultores, os quais se sentem impotentes na exploração de suas propriedades. Na perspectiva das limitações em acessar os recursos de suas propriedades e em realizar suas atividades habituais de uso do meio biofísico para o auto- 
consumo, configura-se um "preservacionismo territorializante", representado pela noção de comando e planejamento do Estado, que exibe controle de áreas extensas (Little, 2002).

Longe de alcançar seus objetivos, esse modelo de conservação resulta em uma não parceria nada eficiente para a proteção da biodiversidade. De sua implantação, deriva sentimentos de abuso de autoridade do poder público e de perda da autonomia, presente nesses povos há gerações, o que culmina em ações anti-conservacionistas graves, por membros dessas comunidades. Podem ser citados, nesse âmbito: incêndios intencionais; oposição à regeneração das regiões de borda de floresta, o que resultaria em "perda" de áreas produtivas, proibidas de serem usadas futuramente; impedimento do crescimento de espécies vegetais especialmente protegidas, mais difíceis ainda de terem o consentimento para seu manejo; coletas não autorizadas e o que mais julgarem essencial para sua subsistência, fora do horário de fiscalização.

\section{Agroecologia do povo para o povo}

Esse confronto entre diferentes projetos de uso e significação dos recursos naturais resulta na constatação de que a conservação da biodiversidade é atravessada por sentidos socioculturais e interesses bastante diferenciados. Evidencia uma condição assimétrica na valorização desses significados, pois as novas demandas sociais que emergem com a ideia de preservação da natureza e com as éticas ditas "ecológicas", muitas vezes, modificam e desestruturam os modos de vida desses agricultores e as formas como eles se relacionam com o ambiente natural (Gerhardt, 2002).

Dessa forma, apreender em seu aspecto dinâmico o modo como as populações locais produzem, significam e justificam seus saberes e práticas, nas relações cotidianas com seu ambiente, tem nos permitido iniciar algumas reflexões no campo da territorialidade. Esse conceito, segundo Little (2002), diz respeito ao

esforço coletivo de um grupo social para ocupar, usar, controlar e se identificar com uma parcela específica de seu ambiente biofísico, convertendo-a assim em seu 'território' ou 'homeland'; é 
construído historicamente, acoplando novas práticas e sentimentos através do cruzamento com perspectivas que - normativas, proibitivas ou valorativas - podem ser visualizadas como 'ambientalizadoras'.

Todos esses processos remetem a um sistema complexo, entrecortado por relações sociais e carregado de conflitos que se definem a partir de interesses distintos. Será um grande desafio alimentar, vestir, medicar, entre outras atividades, uma população esperada de bilhões de pessoas na Terra. Conservar o conhecimento dos agricultores sobre os métodos de cultivos tradicionais, manejo do solo e sementes crioulas é uma parte desse caminho, fundamental para a conservação da sociobiodiversidade e para a segurança alimentar das gerações atuais e futuras.

\section{Referências}

ABREU, L. et al. "Avaliação do rendimento sócio-econômico de variedades crioulas e híbridos comerciais de milho na microregião de Chapecó”. Revista Brasileira de Agroecologia, v. 2, n. 1, pp. 1230-3, 2007.

ADAMS, C. Caiçaras na Mata Atlântica: pesquisa científica versus planejamento ambiental. São Paulo: Annablume; FAPESP, 2000.

et al. "Agricultura e alimentação em populações ribeirinhas das várzeas do Amazonas: novas perspectivas". Ambiente \& Sociedade, v. 3, n. 1, pp. 1-23, 2005.

AFONSO, G. B. "Astronomia indígena”. Anais da $61{ }^{a}$ Reunião Anual da SBPC, Manaus, jul. 2009.

ALTIERI, M. A. Agroecology: the scientific basis of alternative agriculture. Boulder: Westview Press, 2000.

ARRUDA, R. S. V. “Populações tradicionais' e a proteção dos recursos naturais em Unidades de Conservação”. In DIEGUES, A. C. (org.). Etnoconservação: novos rumos para a conservação da natureza. São Paulo: Hucitec, Nupaub - USP, 1997. 
BERTOLINO, A. V. e BERTOLINO, L. C. "Agricultura Migratório e seus efeitos sobre o uso do solo". In CARNEIRO, M. J. et al. Agricultores e território: prática e saberes. Rio de Janeiro: Trasso Comunicação Ltda., 2010.

CAPORAL, F. R. e COSTABEBER, J. A. Agroecologia e extensão rural: contribuições para a promoção do desenvolvimento rural sustentável. Brasília: MDA/SAF/DATERIICA, 2007.

CARNEIRO, M. J. "Ruralidade: novas identidades em construção". Estudo, Sociedade e Agricultura, n. 11, pp. 53-75, Rio de janeiro, out. 1998.

CARPENTIERE-PIPOLO, V. et al. "Avaliação de cultivares de milho crioulo em sistema de baixo nível tecnológico". Acta Scientiarum: Agronomy, v. 32, n. 2, pp. 229-33, Maringá, 2010.

CECCARELLI, S. "Specific adaptation and breeding for marginal conditions”. Euphytica, v. 77, n. 3, pp. 205-19, 1994.

CORREA, C. e WEID, J. M. "Variedades crioulas na Lei de Sementes: avanços e impasses”. Agriculturas, v. 3, n. 1, pp. 12-4, 2006.

COUTINHO, L. M. "Fire in the ecology of the Brazilian cerrado". In: GOLDAMMER J. G. (ed.). Fire in the tropical biota (ecological studies). Berlim: Springer-Verlag, 1990, v. 84, pp. 82-105.

DIEGUES, A. C. "Etnoconservação da natureza: enfoques alternativos". Etnoconservação: novos rumos para a proteção da natureza dos trópicos. São Paulo: Ed. Hucitec, 2000.

EMBRAPA - Empresa Brasileira de Pesquisa Agropecuária. Pesquisa e desenvolvimento em agricultura familiar na Embrapa arroz e feijão. Santo Antônio de Goiás: Embrapa Arroz e Feijão, 2004.

FELIPIM, A. P. O sistema agrícola guarani mbyá e seus cultivares de milho: um estudo de caso na aldeia guarani da Ilha do Cardoso, município de Cananéia, SP (dissertação). USP, 2001.

et al. "Agricultura de pousio e controle ambiental". In: DIEGUES, A. C. e Vianna, V. M. (orgs.). Comunidades tradicionais e manejo dos recursos naturais na Mata Atlântica. 2 ed. São Paulo: Ed. Hucitec: NUPAUB-USP: CEC, 2004. 
FONSECA, O. M. et al. "Mitos e constelações indígenas, confeccionando um planetário de mão". Anais de X Reunión de la Red de Popularización de La Ciencia y La Tecnología en América Latina y el Caribe (RED POP UNESCO) y IV Taller “Ciencia, Comunicación y Sociedad”, San José, Costa Rica, maio 2007.

GARCÍA, M. C. Experiências brasileiras com sementes crioulas: relato de uma viagem (bio)diversa. Rio de Janeiro: PESAGRO - Empresa de Pesquisa Agropecuária do Estado do Rio de Janeiro, 2004.

GERHARDT, C. Agricultores familiares, mediadores sociais e meio ambiente: a construção da problemática ambiental em agro-eco-sistemas (dissertação). Universidade Federal do Rio Grande do Sul, 2002.

GLIESSMAN, S.R. Field and laboratory investigations in agroecology. Boca Ratón: CRC Press LLC, 2000.

IBGE - Instituto Brasileiro de Geografia e Estatística. Produção Agrícola Municipal no Brasil. 2000. Diretoria de Pesquisas, Departamento de Agropecuária. Acesso em: 24 abr. 2015.

JAFELICE, L. C. "Nós e os céus: um enfoque antropológico para o ensino de Astronomia”. Atas do VIII Encontro de Pesquisa em Ensino de Física VIIIEPEF. São Paulo, 2002.

LEFF, E. Ecologia, capital e cultura: racionalidade ambiental, democracia participativa e desenvolvimento sustentável. Blumenau: Furb, 2000.

LEONEL, M. "O uso do fogo: o manejo indígena e a piromania da monocultura”. Estudos Avançados, v. 14, n. 40, São Paulo, 2000.

LIMA, F. P. e FIGUEIRÔA, S. F. M. "Etnoastronomia no Brasil: a contribuição de Charles Frederick Hartt e José Vieira Couto de Magalhães". Boletim Museus Paraense Emílio Goeldi. Cienc. Hum., v. 5, n. 2, pp. 295313, 2010.

LITTLE, P. E. “Territórios sociais e povos tradicionais no Brasil: por uma antropologia da territorialidade”. Série Antropologia, n. 322, Brasília, 2002.

MACHADO, C. T. T. et al. Capacitação, identificação e implantação de sistemas de produção de base ecológica a partir do planejamento segundo a aptidão agro-ecológica e extrativista das terras para aplicação em comunidades 
de agricultores no Território do Alto Rio Pardo. Minas Gerais: Ministério do Desenvolvimento Agrário (MDA), 2010.

MACIEL, R. J. S. e SOUZA, S. G. A. "Práticas de agricultura sustentável realizadas em comunidades tradicionais sob área de várzea em Parintins-AM”. Revista Brasileira de Agroecologia, v. 4, n. 2, pp. 2509-12, 2009.

MICHON, G. e DE FORESTA, H. "Agroforests: pre-domestication of forest trees or true domestication of forest ecosystems?". Netherlands Journal of Agricultural Science, v. 45, n. 4, pp. 51-462, 1997.

MORAN, E. F. Adaptabilidade humana. São Paulo: Edusp, 1994.

MURRIETA, R. S. S. e DUFOUR, D. "Fishand farinha: protein and energy consumption in amazonian rural communities on Ituqui Island, Brazil”. Ecology of Food and Nutrition, v. 43, pp. 1-25, 2004.

NAIR, P. K. R. An introduction to Agroforestry. Dordrecht, The Netherlands: ICRAF, 1993.

NAVES, M. M. V. et al. "Avaliação química e biológica da proteína dogrão em cultivares de milho de alta qualidade protéica". Pesquisa Agropecuária Tropical, v. 34, n. 1, pp. 1-8, 2004.

PEROTTO, M. A. A influência da legislação ambiental no uso e conservação da bacia hidrográfica do rio Maquine (RS), no período de 1964 a 2004 (dissertação) Universidade Federal de Santa Catarina, 2007.

PINTO, J. G. e GARAVELLO, M. E. P. E. “Transformação (agri)cultural ou etnossustentabilidade: relato de uma aldeia Bororo". Agroecologia e Desenvolvimento Rural Sustentável, v. 3, n. 2, pp. 54-60, 2002.

PRETTY, J. N. "Alternative systems of inquiry for sustainable agriculture”. IDS Bulletin, v. 25, n. 2, pp. 37-48, 1994.

QUINTEIRO, M. M. C. Etnobotânica aplicada à definição de formas tradicionais de uso, manejo e percepção doe recursos vegetais em Visconde de Mauá: ações conjuntas para etnoconservação florestal da Mata Atlântica (tese). Universidade Federal Rural do Rio de Janeiro, 2012.

e MORAES, M. G. "Etnociências aplicadas como ferramenta para educação ambiental: resgatando os saberes complexos”. In: GUIMA- 
RÃES, M. e FONSECA, L. Educação em ciências e educação ambiental - caminhos e confluências. 1 ed. Seropédica: EDUFRRJ, 2012, pp. 59-69.

et al. "Proposta de integração entre a etnobotânica e a agrofloresta em Manejos Florestais Comunitários (MFC) para fins conservacionistas". Revista Brasileira de Agroecologia, v. 4, n. 2, pp. 1016-9, 2009.

et al. "Formas de retorno da pesquisa etnobotânica à comunidade no paradigma da complexidade ambiental e educação ambiental". Revista Brasileira de Educação Ambiental, v. 8, n. 1, pp. 91-9, Rio Grande, 2013.

SANTILLI, J. "A Lei de Sementes brasileira e os seus impactos sobre a agrobiodiversidade e os sistemas agrícolas locais e tradicionais". Boletim Museu Paraense Emílio Goeldi - Cienc. Hum., v. 7, n. 2, pp. 457-75, Belém, maio-ago. 2012.

SILVA, L. F. Solos tropicais: aspectos pedológicos, ecológicos e de manejo. São Paulo: Terra Brasilis Editora Ltda., 1996.

SINCLAIR, F. L. e WALKER, D. H. "A utilitarian approach to the incorporation of local knowledge in agroforestry research and extension". In: BUCK, L. E. et al. (orgs.). Agroforestry in sustainable agricultural systems. Boca Ratón: CRC Press, 1999. Disponível em: http://www. books.google.com/books. Acesso em: 5 jun. 2008.

UNESCO. 2010. Astronomyand World Heritage Initiative. Disponível em: http://www.astronomicalheritage.net/. Acesso em: 17 jul. 2010.

VARELLA, L. B. "Sustentabilidade prospectiva do sistema taungya em comparação com a roça tradicional na zona Bragantina do estado do Pará”. Movendo Idéias, v. 8, n. 14, pp. 73-85, 2003.

VIVAN, J. L. Saber ecológico dos agricultores e sistemas agroflorestais: um estudo de caso na Floresta Atlântica do litoral norte do estado do RS, Brasil (dissertação). Universidade Federal de Santa Catarina, 2000. 
$\frac{1}{2}+2$

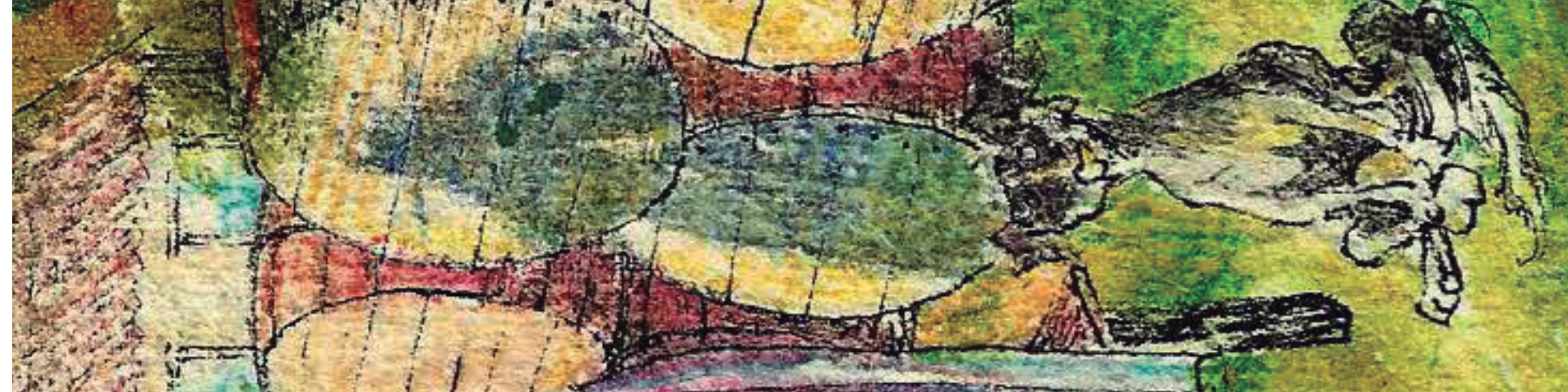

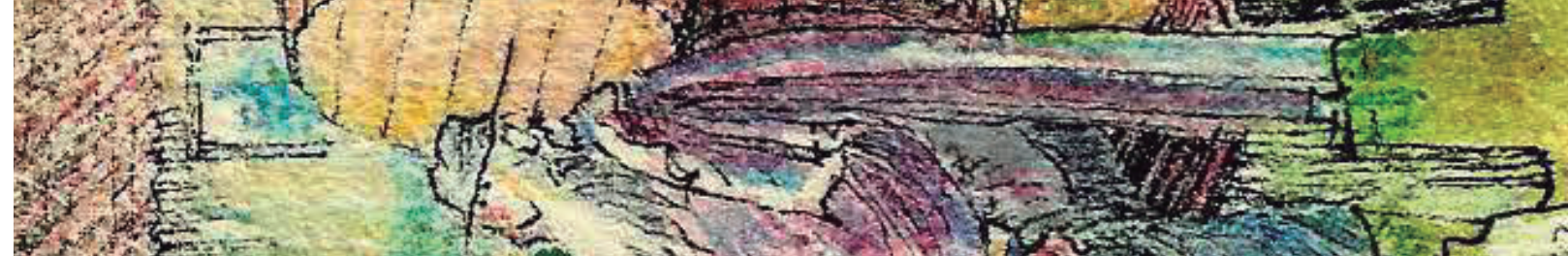

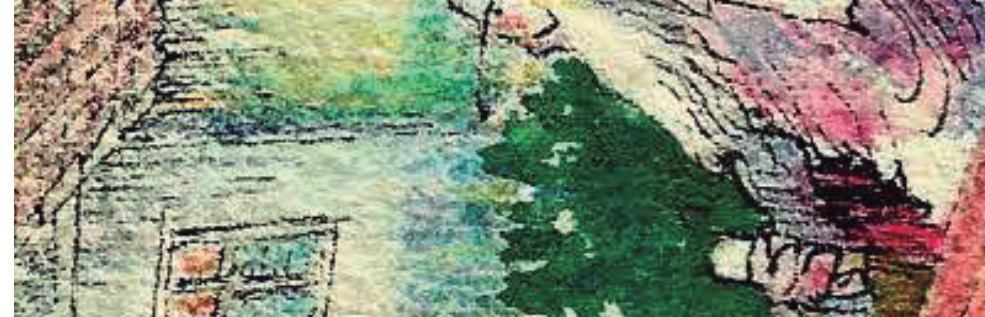

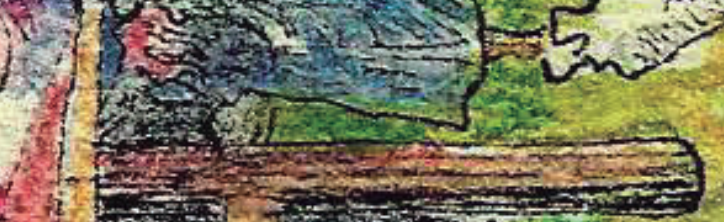

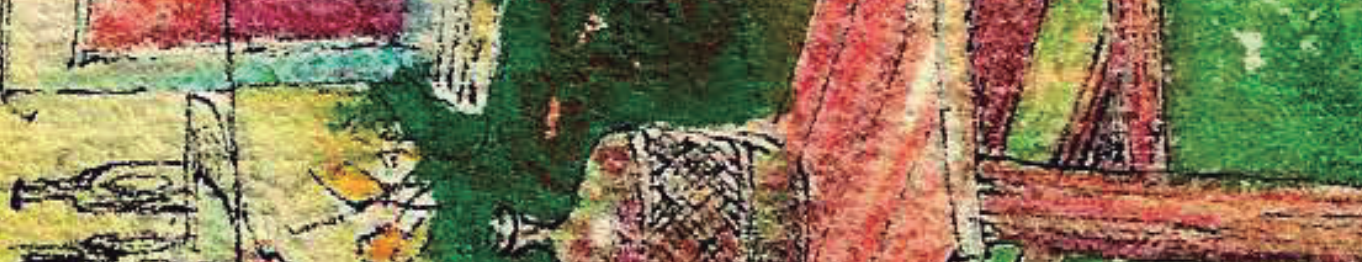

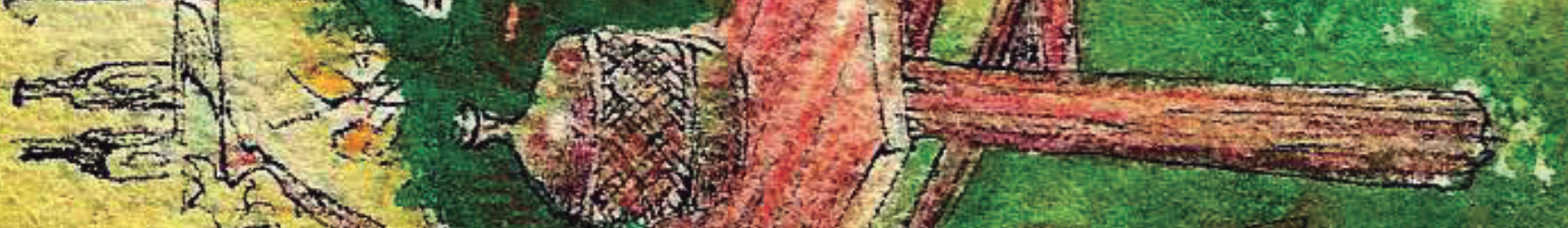

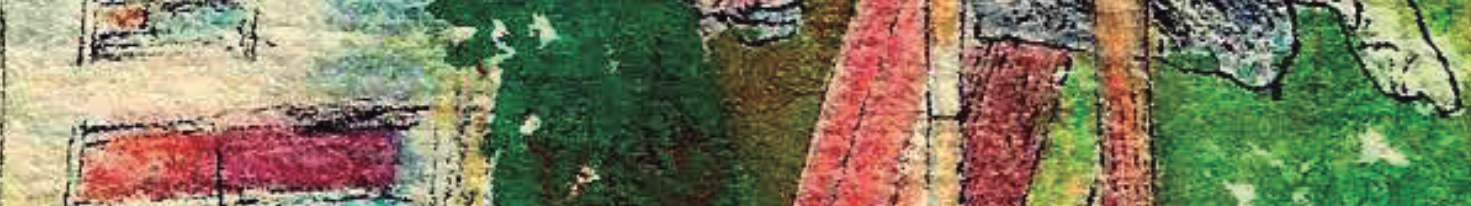

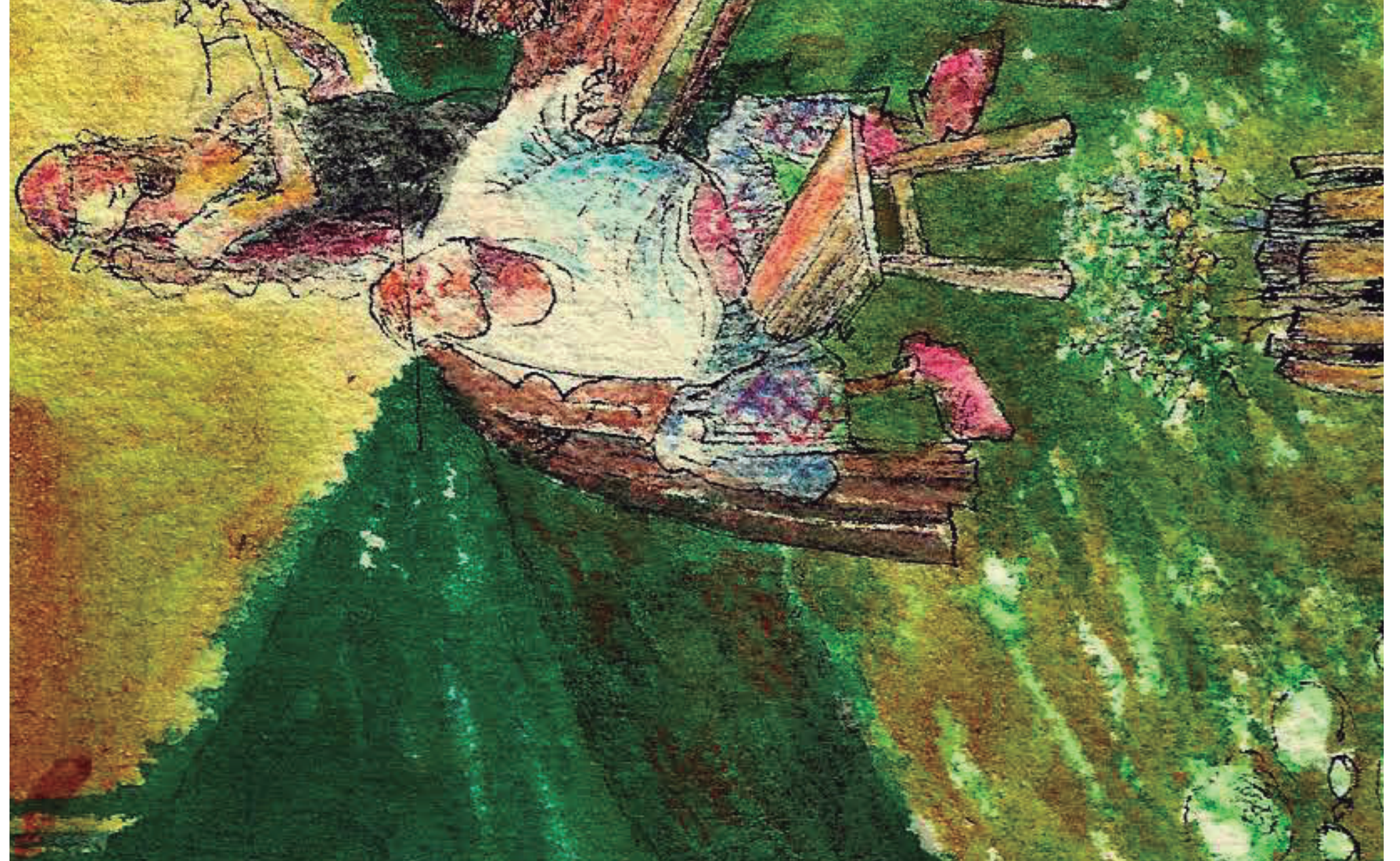




\title{
CAPÍTULO III
}

\section{Saberes tradicionais e a segurança alimentar}

\author{
Odara Horta Boscolo \\ Joyce Alves Rocha
}

\section{Saberes tradicionais: um valor diferencial}

De forma geral, os grupos humanos, dispondo de recursos tanto em ambiente antropogênico como em área natural, tendem a conceber os recursos vegetais segundo uma concepção de utilidade, que pouco tem a ver com a compreensão dos pesquisadores. O significado da utilidade de uma planta varia muito de comunidade para comunidade e de pessoa para pessoa. De certo modo, a utilidade pode não se concretizar na materialidade, mas pode estar muito ligada às práticas imateriais que se estabelecem enquanto patrimônio cognitivo de uma dada comunidade, pois o conhecimento sobre um determinado uso não tem a ver somente com seu uso prático, mas com a capacidade de atender às múltiplas necessidades de uma população.

A utilização de plantas combina uma série de fatores, mostrando a interdependência entre o homem biológico, o social e o cultural. Dessa forma, as relações entre o ser humano e o meio ambiente são estabelecidas. O interesse das pessoas pelo conhecimento sobre as plantas se confunde com a sua própria história (Almeida, 2003). Os primeiros registros encontrados revelam uma forte relação do homem com os vegetais como matéria-prima para suprir suas necessidades básicas. Trata-se do conhecimento humano a respeito dos recursos naturais, que é construído pelo tempo de interação entre estes (a partir de sistemáticas observações), o que gera processos adaptativos garantidores da sobrevivência de sociedades humanas em determinados ambientes. Tal interação constitui-se 
em um saber experimentado nas tarefas e prática diárias e na pluralidade cultural das populações humanas habitantes dos mais diversos ambientes (Guarim-Neto e Carniello, 2007).

Branquinho (2007) pondera que o interesse pelos saberes tradicionais tem assumido novas tendências, a fim de enfrentar os atuais problemas socioambientais, que exigem a emergência de soluções interdisciplinares para lidar, por exemplo, com as questões de manutenção da biodiversidade global e com a segurança alimentar. Desse modo, consolida-se o ponto de vista de que as plantas e o conhecimento sobre elas são fatores indissociáveis, e que, portanto, investigações a esse respeito precisam considerar o contexto sócio-histórico, o ecológico, as tradições em que se baseiam e a cultura mantida no local, constituindo um cenário multifacetado para elaboração desse conhecimento.

É com base no saber sobre a natureza, mantido por um modo de vida peculiar dentro dessas populações, que conhecimentos são gerados, selecionados, mantidos e transmitidos, em sua maioria oralmente, de geração a geração (Pirrelli, 2008; Rezende-Silva, 2012).

Os saberes tradicionais podem ser compreendidos no sentido de experiências e conhecimentos acumulados por um grupo humano sobre seus recursos naturais e transmitidos de forma dinâmica, mutável e transgeracional, podendo passar por transformações e adaptações ao longo do tempo, e de acordo com uma gama de conjecturas e interesses envolvidos (Albuquerque, 2005; Elisabetsky, 2003).

Nos últimos dois séculos, esses saberes, apesar de gerar e orientar as práticas sociais desde sempre, continuam a não ter status de ciência. Durante séculos, os ricos conhecimentos elaborados e mantidos por grupos sociais considerados à margem da sociedade arrastaram consigo $\mathrm{o}$ sentido de desvalor relacionado às expressões "conhecimento popular" e "conhecimento vulgar", o que demarcou o distanciamento entre esses saberes e o mundo das ciências.

Mas, afinal, o que pode ser considerado como saberes tradicionais? Tendo como princípio que o conhecimento empírico das gerações anteriores a nossa está presente em nós e no meio em que vivemos, ele pode ser entendido como conhecimento adquirido através de tentativas e erros, num agrupamento de ideias e ações que pode ser considerado válido, observável, analisável, compreensível, e até replicável, mesmo que seja considerado fora dos padrões cientificistas. Para Bandeira (2001), o que 
permite distinguir os conhecimentos tradicionais dos conhecimentos científicos não é uma questão hierárquica, e sim o fato de não corresponderem às teorias construídas tal qual o modelo ocidental moderno. Trata-se de formas de conhecimento guiadas por critérios de validade locais (materiais e simbólicos), podendo sofrer variações regionais e culturais; e serem fortemente vinculadas aos contextos nos quais vêm sendo produzidas e transmitidas.

Mesmo aceitando seu dinamismo, é preciso considerar que os saberes localmente construídos associados aos recursos naturais têm sofrido ameaças de modificações extremas, muito além de seu potencial de resiliência. A erosão desses saberes está muito associada ao abandono dos esquemas de manejo dos recursos e às alterações no modo de vida das populações (Berkes, 1999). Segundo Amorozo (2007), esse processo de interferência na manutenção dos saberes tradicionais tem limitado a flexibilidade e a capacidade adaptativa do mesmo. De acordo com a autora, razões como a superação do valor de uso pelo valor de mercado, a introdução de tecnologias de exploração mais agressivas, as modificações na densidade populacional, as condições de subsistência no local, o desemprego, dentre outras, têm levado a alterações de difícil reversão, tanto para o meio ambiente quanto para as populações ligadas a ele.

\section{Plantas alimentícias: perda de sua diversidade}

Desde que o homem era estritamente caçador-coletor, já conhecia os recursos da natureza e os usava para diversos fins, incluindo a alimentação. Há cerca de 10 mil anos, o homem torna-se sedentário e passa a domesticar animais e plantas, desenvolvendo a agricultura. E, hoje em dia, esses conhecimentos vêm se transformando, perdendo, e os etnobotânicos, em certa medida, se esforçam para fornecer subsídios para valorizá-los.

Estamos vivendo em um momento de grandes mudanças climáticas globais e de forte pressão para aumentar drasticamente a produção de alimentos, a fim de atender ao crescimento da população mundial. A prática da monocultura - consequentemente, a perda dos saberes tradicionais e da biodiversidade - é uma ameaça real e ocorre de forma rápida, em todos os lugares do planeta. 
Um outro grave problema apontado por economistas da $\mathrm{FAO}^{1}$ é a especulação orquestrada pelos mercados futuros. Segundo a entidade, as manobras especulativas do mercado contribuem para elevar os preços dos alimentos, o que dificulta a aquisição.

Juntos, a especulação e os fenômenos climáticos extremos já somam razões suficientes para desequilibrar toda a oferta de alimentos mundial. Mas ainda tem mais: a má distribuição decorrente de diversos fatores econômicos e políticos. Para se colocar alimento ao alcance das pessoas, não é questão apenas de aumentar a produção global, mas sim de que esses alimentos tenham a garantia de produzir, distribuir até o consumidor final. Estudos feitos pelo órgão das Nações Unidas concluem que há alimentos suficientes para alimentar toda a população do planeta. $\mathrm{O}$ problema é que eles não chegam onde mais se precisa, o que vem sendo agravado, no Brasil, nas últimas cinco décadas.

Nem precisamos ir muito atrás. Pensemos em nossos avós: eles tinham uma dieta muito mais variada que a nossa. Conte nos dedos o que encontramos nos mercados e hortifrútis: umas 25 espécies, no máximo cinquenta, que incluem bananas, maçãs, batata, cebola, ou seja, espécies encontradas em praticamente qualquer mercado do mundo. Segundo a FAO (2014), o comércio mundial se faz com cerca 110 espécies, sendo as mais importantes o trigo, o milho, a batata e o arroz. Em terceiro plano, ficam nossas espécies nativas, que detêm alguma importância local, mas não avolumam o mercado, como a mandioca, abacaxi, caju, cupuaçu, maracujá, castanha, guaraná, jabuticaba, amendoim, açaí, dentre outras (Santilli 2009).

Mesmo com toda essa riqueza de espécies vegetais nativas, a agricultura brasileira está apoiada no cultivo de poucas e exóticas espécies domesticadas. De acordo com Coradin (2006), a agricultura brasileira está baseada em recursos genéticos da cana-de-açúcar proveniente da Nova Guiné, do café da Etiópia, do arroz das Filipinas, da soja e da laranja da China, da batata da região andina, do milho do México, do cacau da América Central e México e do trigo da Ásia menor. Das quatro espécies cultivadas mais importantes para o homem (arroz, batata, milho e trigo),

1 Food and Agriculture Organization - Organização das Nações Unidas para Alimentação e Agricultura. 
nenhuma tem como centro de origem o Brasil. Se considerarmos a produção e o consumo global, dentre os quinze cultivos mais importantes para o homem, apenas a mandioca e o amendoim são nativos do nosso território.

Existem na Terra cerca de 50 mil espécies de plantas, 3.000 já foram usadas para alimentação, mas apenas trinta culturas são responsáveis por fornecer $95 \%$ da energia fornecida pelos alimentos consumidos pelos seres humanos; a maior parte delas (60\%) se resume a arroz, trigo, milho, milheto e sorgo (Alisson, 2013). Estudos etnobotânicos têm registrado, porém, mais de 17 mil espécies comestíveis no mundo todo e suspeita-se ser mais do que $60 \mathrm{mil}$ as que realmente existam. No fim, usamos cerca de 150 espécies, ou seja, menos de $1 \%$ do que a natureza nos oferece (Rapoport, 2009).

Estamos perdendo não somente as espécies em si, mas também as variedades agrícolas. Nos últimos cem anos perdemos entre $90 \%$ e $95 \%$ dessas variedades, e há estimativas de que a taxa de perda da diversidade genética vegetal seja de $2 \%$ ao ano (Coupe e Lewins, 2007).

Esses números começaram a se delinear a partir de 1930, quando a prática milenar da agricultura começou a mudar. Plantas mais produtivas avançaram para o campo, expulsando culturas antigas. Foram desenvolvidas e selecionadas variedades de plantas capazes de absorver e potencializar os efeitos do uso crescente de adubos e fertilizantes químicos. Para a adaptação das plantas, a mecanização e as exigências da indústria agroalimentar, foram selecionadas variedades em função de características mais adequadas a colheita mecânica, variedades mais homogêneas quanto a data de maduração e mais fáceis de debulhar. As melhores espécies eram escolhidas e cruzadas com as nativas, criando os híbridos, com a promessa de encher o planeta com plantas mais produtivas e com mais facilidade para o cultivo mecanizado em larga escala (Pollan, 2008).

A Revolução Verde ${ }^{2}$ trouxe também problemas com as sementes; as submetidas ao melhoramento vegetal tomaram lugar das nativas. Tal

2 Conceitualmente, a Revolução Verde é considerada como a difusão de tecnologias agrícolas que permitiram um aumento considerável na produção, sobretudo em países menos desenvolvidos, que ocorreu principalmente entre 1960 e 1970, a partir da modernização das técnicas utilizadas. Embora tenha surgido com a promessa de acabar com a fome mundial, não se pode negar que essa revolução trouxe inúmeros impactos sociais e ambientais 
substituição não atingiu somente as variedades de sementes, mas também diversas culturas no mundo. As sementes locais passaram a ser conhecidas como inferiores, embora estas safras, que foram consideradas marginais, contenham mais nutrientes e sejam mais produtivas do que as melhoradas (Pollan, 2008).

Essas práticas trouxeram uma acelerada erosão genética. Por exemplo, existia na Índia, até pouco tempo, 3.000 variedades de arroz desenvolvidas por comunidades locais; hoje, está reduzida a apenas treze. Destino parecido tiveram o trigo grego e o milho mexicano. Uma das consequências dessa erosão foi vista em 1970, nos EUA: uma raça mutante de fungo devastou os milharais americanos; cerca de $80 \%$ do milho provinha de uma semente híbrida. Outra decorrência foi após a descoberta das Américas. Os europeus levaram para Europa apenas uma variedade de batata, e, em 1845, uma praga pegou essa espécie. Foi a "fome da batata", que na Irlanda levou à morte, por fome, de um milhão de pessoas (Pollan, 2007).

Estamos pagando caro pelos resultados da Revolução Verde. As plantas estão mais suscetíveis a doenças, pragas, e exigem uma quantidade maior de insumos químicos. Como consequência, temos a contaminação dos alimentos, intoxicação humana e animal, contaminação da água e dos solos, erosão, salinização, desertificação, devastação de florestas, marginalização socioeconômica, perda de autossuficiência alimentar, êxodo rural, imigração para as cidades, desemprego e uma brutal redução da diversidade de espécies e variedades de plantas existentes no planeta (Santilli, 2009).

No Brasil, ao mesmo tempo que há tentativas de livrar-se da dependência das sementes estrangeiras, não há ainda o cuidado de garantir a produção e comercialização, em larga escala, de plantas muito utilizadas pela população, como quiabo, jiló e mandioca. Em muitas cidades brasileiras, as hortaliças consumidas são produzidas em outros estados,

negativos. Além de não ter resolvido os problemas nutricional e da fome, a Revolução Verde também é reconhecida por aumentar a concentração fundiária e a dependência de sementes, alterando a cultura dos pequenos proprietários que encontraram dificuldades para se inserir nos novos moldes. A concentração da posse da terra e o decorrente êxodo rural causaram um inchaço das cidades, levando a uma favelização nunca vista. Houve uma transferência do lucro decorrente da atividade agrícola para a agroindústria, deixando o produtor rural com uma estreita margem, levando ao seu endividamento (Otaviano, 2010). 
tendo como consequências altos preços, baixo consumo e deterioração nutricional.

Para combater essa situação, muitos pesquisadores criam artifícios para produzir espécies de outras regiões - por exemplo, aplicação de insumos químicos, construção de custosas casas de vegetação, fervura e esterilização de solo e sementeiras. Outros pesquisadores procuram coletar, selecionar, conservar e reintroduzir espécies regionais, que até então sua existência no habitat natural foi posta em risco pela expansão das fronteiras agrícolas (Pollan, 2007).

Onde estão o cubiu (Solanum sessiliflorum Dunal), feijão macuco ( $\mathrm{Pa}$ chyrhizus tuberosus [Lam.] Spreg.), marolo (Annona crassiflora Mart.), taiobas (Xanthosoma sp.), ariá (Calathea allouia [Aubl.] Lindl.) e outros então consumidos por nossa população? Há estimativas de que a perda de uma planta pode causar o desaparecimento de quarenta tipos de animais e insetos que dela dependem para sobreviver, além de combinações genéticas e moléculas únicas na natureza (Santilli, 2009). Nesse caso, pode entrar a contribuição do pequeno agricultor local, que não precisa ficar na dependência de variedades de alta produtividade e nem do pesado apoio tecnológico para se manter no mercado. Pode também se dar ao luxo de cultivar espécies e variedades em extinção. A seleção de variedades por meio de processos de inovação conduzidos pelos agricultores, assim como o intercâmbio de saberes agrícolas e sementes, são práticas tão antigas quanto a própria agricultura. A enorme diversidade de plantas cultivadas e ecossistemas agrícolas existentes no mundo deve-se a tais práticas locais e tradicionais.

Outro fator da perda das espécies domesticadas, como também seus parentes silvestres, é a devastação dos ecossistemas. Isso demonstra a necessidade urgente de domesticar espécies de uso reconhecido popular, reflorestar áreas degradadas, racionalizar o uso das florestas. (Ming et al., 2010). A preservação, tanto dos saberes tradicionais quanto da vegetação nativa e exótica introduzidas no passado, que fazem parte do uso por populações, é necessária, pois o resgate das espécies potencialmente úteis é de fundamental importância para a manutenção de processos ecossistêmicos e sociais locais (Santilli, 2009).

Existem muitos desafios para a conservação de espécies com fins alimentícios. Esta questão não é, entretanto, apenas uma questão ambiental. A segurança alimentar e nutricional de toda a população, o desen- 
volvimento rural sustentável, a inclusão social e o combate à fome e à miséria estão, direta ou indiretamente, relacionados à conservação e ao uso dos recursos da biodiversidade. Hoje cerca de $75 \%$ dos mais pobres do mundo - 1,2 bilhão de pessoas - vivem em áreas rurais e dependem da agricultura para sua subsistência (Santilli, 2009).

Os pequenos agricultores, pertencentes a populações tradicionais ou não, são os maiores promotores e detentores da diversidade agrícola mundial e possuem uma forte ligação com seus modos de vida. Suas culturas são baseadas na produção para subsistência, podendo ocorrer a venda de excedentes, na mão-de-obra familiar, na tecnologia simples e principalmente cultivando várias espécies diferentes em uma mesma área. Essas práticas garantem a segurança alimentar e nutricional, ao mesmo tempo que asseguram o plantio contra estresses abióticos e bióticos, como as alterações climáticas e ataques de pragas e doenças (Cultrera, 2008).

Conforme Castro (1995), no Brasil, apesar de parcos estudos relacionados com a avaliação nutricional dos componentes alimentícios produzidos nos quintais, estes, geralmente, representam, para as populações de baixa renda, uma contribuição significativa na dieta alimentar familiar. Praticamente em todas as regiões do país, os quintais assumem um importante papel na subsistência sustentada da população brasileira.

Observamos aqui no Brasil e em muitos países que o modelo da agricultura industrial está mudando o estilo de vida dessas populações rurais (Amorozo, 2006). Agricultores comerciais e pecuaristas pressionam os pequenos agricultores, e estes são coagidos a vender suas terras, ou são desestimulados a continuar plantando. A concorrência torna-se desleal e o preço de mercado do agronegócio fica impraticável para o pequeno produtor. Os programas do governo e outras multinacionais do agronegócio estimulam o uso de sementes melhoradas e o uso de insumos químicos e maquinários modernos, em vez do uso de sementes locais ou crioulas, tornando uma ameaça à economia agrícola familiar. Segundo Amorozo (2006), essas intervenções desestabilizam e desarticulam os sistemas agrícolas voltados para a subsistência, além de terem efeito negativo sobre o conjunto de germoplasma de plantas de cultivo, que estas sociedades mantêm, e sobre os saberes tradicionais.

No âmbito das ações governamentais, em 2011, foi instituído um Programa de Fomento à redução da pobreza, que surgiu a partir do eixo 
de inclusão produtiva do Plano Brasil Sem Miséria. ${ }^{3}$ De acordo com a Lei Federal n. ${ }^{\circ}$ 11.326/2006, existem formas de obter apoio financeiro se inserindo no eixo de inclusão produtiva do governo federal, que subsidia agricultores familiares ${ }^{4}$ e povos e comunidades tradicionais em situação de pobreza. Esses recursos apoiam o desenvolvimento do projeto produtivo de cada família e permitem ampliar ou diversificar a produção de alimentos e as atividades geradoras de renda.

No caso de populações tradicionais, outra verba governamental disponível para fomento à geração de renda que pode ser obtida por comunidades tradicionais advém da Política Nacional de Desenvolvimento Sustentável dos Povos e Comunidades Tradicionais ${ }^{5}$ que apoia projetos específicos, definidos por meio de editais públicos, e que auxiliam as famílias a produzirem alimentos de qualidade, com regularidade e em quantidade suficiente para o autoconsumo. Para buscarem a inserção nessa seara, eles reconhecem necessitar de mecanismos para compreender o processo e consideram ser fundamental motivar alguns de seus membros a se instrumentalizarem para encarar esse desafio, em favor dos demais.

3 Responsabilidade conjunta do Ministério do Desenvolvimento Social (MDS) e do Ministério do Desenvolvimento Agrário (MDA). O objetivo fundamental é possibilitar que os beneficiários possam produzir para o seu consumo e melhorar a alimentação de sua família, bem como obter renda por meio da comercialização da produção, participando de uma rota de inclusão produtiva.

4 Aqui a concepção de agricultura familiar está amparada no que preconiza o artigo $3{ }^{\circ}$ da Lei Federal n. ${ }^{\circ} 11.326$ de 24 de junho de 2006, o qual determina que o estabelecimento para ser classificado como familiar deve apresentar, a qualquer título, área inferior a 4 (quatro) módulos fiscais e utilizar predominantemente mão-de-obra da própria família nas atividades econômicas do seu estabelecimento ou empreendimento.

5 Por meio do Decreto n. ${ }^{\circ}$ 6.040/2007, instituiu-se a Política Nacional de Desenvolvimento Sustentável dos Povos e Comunidades Tradicionais (PCTs) que define esses povos como grupos culturalmente diferenciados e com formas próprias de organização social. Esses grupos ocupam e usam, de forma permanente ou temporária, territórios tradicionais e recursos naturais como condição para sua reprodução cultural, social, religiosa, ancestral e econômica. Para isso, são utilizados conhecimentos, inovações e práticas gerados e transmitidos pela tradição. 


\section{Precisamos sair da mesmice}

O ato de comer, que é um dos alicerces de nossas tradições sociais, familiares e rituais, regrediu a um ato de irritação, pressa e culpa. O próprio significado do alimento e alimentação está sendo transformado; antes era um elemento central para a manutenção da estrutura social e da tradição, e hoje está sendo extorquido pela cultura alimentar globalizada, na qual o custo e a conveniência são dominantes e a refeição social tornou-se obsoleta.

Até pouco tempo atrás acreditava-se que o problema alimentar resumia-se à fome, entretanto foi preciso que o mundo acumulasse excedentes consideráveis de produção, ao mesmo tempo que persistia a fome em diferentes partes do planeta, para que essa limitada tese fosse desmoralizada, ainda que não abandonada por aqueles que também insistem em que meros avanços tecnológicos com seus suspeitos incrementos na produção podem, isoladamente, eliminar a fome.

A constatação de que a produção de alimentos é suficiente para assegurar alimentação adequada para todo o mundo leva Adas (1988) a afirmar que o problema da fome não é crise de alimentos, e sim seu mau uso, desperdício, concentração de riquezas e é a expressão biológica de um problema social.

Outro fato muito importante em que precisamos atentar é que negligenciamos e subutilizamos as espécies nativas com potencial alimentício. Nossa biodiversidade tem uma grande capacidade de uso alimentar a ser pesquisado para que haja maior variação de nosso cardápio, seja fonte de renda familiar e diversifique nossa matriz agrícola.

Outro ponto relevante é a devastação da biodiversidade brasileira em prol do incremento da produção mundial de soja, milho e trigo, que alimentam bois, frangos, porcos e peixes, principalmente de outros países. Ao reduzir à tamanha limitação de variedades, percebemos o empobrecimento alimentar a que estamos submetidos. A liberdade dos cultivos, a diversificação nutricional e espacial não fazem parte desse modelo que transformou em monocultura o rico cerrado brasileiro. Também prejudica a vida de muitos agricultores familiares e outros, que vivem endividados junto às multinacionais produtoras de sementes. 
Kinupp (2007) é um dos maiores entusiastas da introdução de plantas ruderais como fonte complementar de alimentação e exalta seu poder nutricional que muitas vezes é superior às hortaliças a que estamos acostumados a consumir.

Ainda sobre o potencial dessas plantas ruderais, também conhecidas como daninhas, Rapoport et al. (2009) lembra que a aveia era originalmente uma erva daninha de campos de trigo. Tornou-se tão abundante que, finalmente, o homem percebeu que, em vez de excluí-la, era melhor cultivá-la. Muitas espécies cultivadas, em algum momento e lugar, eram ervas daninhas. Exemplos incluem o centeio, chicória, rabanete, nabo, espinafre, beterraba, alho-poró, alface e outros vegetais. Molina-Martínez (2000) conclui que a presença dessas ervas daninhas úteis em uma cultura pode ser uma vantagem para o agricultor, porque o seu uso não requer investimento financeiro e pode, em vez disso, um gerar renda em dinheiro.

Vandana Shiva, famosa ativista ambiental indiana, gosta de afirmar que a primeira violência contra um saber local é não o considerar um saber e a invisibilidade é a primeira razão para qual os sistemas de saber local entram em colapso. Ou seja, muitos saberes tradicionais relacionados ao uso alimentício da vegetação nativa e exótica introduzida no passado também vêm se perdendo. Muito se deve ao preconceito com esses alimentos considerados inferiores e também à resistência à incorporação de novos pratos. Devemos experimentar novos sabores e novas receitas além do feijão com arroz e pão com manteiga.

O empobrecimento da variedade de alimentos foi agravado pela imposição dos mercados e vem gerando uma homogeneização das dietas mundiais. A situação é alarmante se pararmos para pensar na quantidade de comida industrializada a que estamos expostos e que consumimos. Os grãos refinados e os alimentos com eles processados estão nos limites da ciência reducionista quando aplicados a algo tão complexo como os alimentos (Pollan, 2008). É muito comum lermos nas embalagens dos produtos nas prateleiras dos mercados os seguintes constituintes "enriquecido com vitamina X, Y, Z.", "enriquecido com ferro e ácido fólico", "rico em fibras". Alguns experimentos lúdicos realizados com crianças mostraram que elas não conhecem uma berinjela, uma mandioca, uma couve-flor e, por mais incrível e triste que pareça, muitas só reconheceram uma batata quando apresentada em um pacote azul plástico de batatas fritas, ainda fechado. 
Porém, há esperança. Pesquisas mostram que os brasileiros estão procurando se alimentar melhor, e isto significa maior consumo de produtos frescos e orgânicos. Há uma preocupação crescente com o consumo de frutas e verduras e, desde 2008, o crescimento do mercado foi de $10 \%$, segundo um relatório de maio da consultoria Euromonitor (2014).

Os alimentos naturais e frescos são mais benéficos a saúde, são mais baratos, mais equilibrados, com menos gordura e açúcar. Há anos que os nutricionistas sabem que uma dieta rica em grãos integrais reduz o risco de diabetes, doenças do coração e câncer. A fibra, o ácido fólico e outras vitaminas não agem sozinhas, e sim em uma sinergia (Pollan, 2008). O envelhecimento de nossa população, as altas taxas de diabetes, doenças cardíacas e obesidade - mais de $50 \%$ estão acima do peso, segundo o "estudo do Impacto Global de doenças" publicado em maio (Gloyd, 2014) - têm levado nossa população a buscar opções mais saudáveis.

Plantas cultivadas organicamente contêm mais compostos secundários - produzidos para se defenderem de pragas e doenças -, muitos deles com importantes efeitos antioxidantes e anti-inflamatórios. Pesquisadores descobriram que cruzamentos feitos para melhorar as variedades de trigo nos últimos 130 anos reduziram os níveis de ferro em $18 \%$ e os de zinco e selênio, praticamente em um terço. $\mathrm{O}$ avanço da agricultura industrial teve um preço: produzir alimentos com muito mais calorias por hectare e menos valor nutritivo que antes; é a quantidade em detrimento da qualidade (Pollan, 2008).

Ainda sobre os alimentos orgânicos, houve um avanço de $20 \%$, em 2013, na produção destes em comparação com o ano anterior. São 7.000 produtores e mais de 10 mil unidades de produção orgânica em funcionamento no país, segundo o Ministério da Agricultura. O Brasil ainda compra orgânicos de 2.000 unidades de países da América do Sul, do Norte, Europa, Ásia e Oceania (MAPA, 2014). Mesmo com um maior incentivo de políticas públicas do governo na produção orgânica e agroecológica, muitas vezes o produtor não tem condições de escoar sua safra.

É clara a debilidade do apoio governamental ao cultivo das hortaliças e em relação a culturas de soja, milho, cana-de-açúcar, dentre outras. Combater altos preços das hortaliças, aumentar decisivamente seu consumo, usá-las amplamente na luta contra desnutrição dos brasileiros são desafios que os sucessivos governos não enfrentaram para valer. Os produtores 
queixam-se de que o governo ainda não se deu conta de que as hortaliças produzem bem em áreas pequenas e em curto espaço de tempo.

Maior produtividade não significa, necessariamente, desmatar novas áreas, mas sim cuidar melhor da terra e controlar os desperdícios, já que muito do que é produzido é desperdiçado ou acaba sendo usado como alimento para animais. Precisamos de qualidade, e não de quantidade. Não adianta batermos recordes na produção se ela está carregada de agrotóxicos.

Precisamos nos atentar para outra questão. A falta de estudos da nossa biodiversidade no que tange às plantas alimentícias gera um ciclo vicioso. Se as plantas são pouco conhecidas, serão pouco utilizadas; se são pouco utilizadas, serão pouco produzidas; e, dessa forma, não gera renda, não diversifica os cardápios, nem amplia a diversidade de alimentos. É necessário quebrar este ciclo em que a falta de produção impede a criação da demanda.

Mais do que um simples acervo de sementes locais, bancos de germoplasma podem representar a construção da soberania alimentar da comunidade, com vistas também à comercialização dessas espécies, que, por meio da identificação, seleção e multiplicação de variedades tradicionais, amplia as possibilidades e resguarda o etnoconhecimento e a biota local. ${ }^{6}$ Semente local é também denominada semente crioula, na lógica da adaptação a ambientes específicos, práticas de manejo e costumes. Essa lógica se choca frontalmente com as políticas de distribuição de sementes baseadas na disseminação de uma ou poucas variedades comerciais. O tema é de tamanha relevância que a Comissão de Agricultura, Pecuária, Abastecimento e Desenvolvimento Rural aprovou projeto de lei que cria a Política Nacional de Incentivo à Formação de Bancos Comunitários de Sementes e Mudas de Variedades e Cultivares Locais, Tradicionais ou Crioulos

6 O quilombo André Lopes, no Vale do Ribeira (SP), está chamando a atenção de diversos pesquisadores para as suas roças. São mais de 350 anos de cultivo e, há dois anos, a Fundação Instituto de Terras (Itesp), entidade vinculada à Secretaria da Justiça e Defesa da Cidadania do Estado de São Paulo, percebeu a riqueza das plantações de feijão, arroz e milho da comunidade. As roças, que são utilizadas para a subsistência das famílias, possuem alguns tipos de sementes que surgiram lá e não são conhecidas em outros lugares. 
(PL 6176/13), ${ }^{7}$ que visa beneficiar aqueles que multiplicam sementes ou mudas para consumo próprio, distribuição, troca e comercialização. ${ }^{8}$

\section{Segurança alimentar}

A alimentação adequada é um direito de todos e a segurança alimentar está relacionada ao acesso seguro, suficiente e constante de alimentos para a dieta humana (Maxwell e Smith, 1992). Esta segurança não pode comprometer o acesso a outras necessidades essenciais, e deve ser baseada em práticas alimentares que favoreçam a saúde, respeitem a diversidade cultural, ambiental, econômica e sejam socialmente sustentáveis (Brasil, 2006).

Após décadas achando que a Revolução Verde e a industrialização dos alimentos (plantas e animais) iriam resolver os problemas enumerados, no ensaio sobre o princípio da população malthusiano, e que o sistema alimentar, calcado em imensas redes de produção e distribuição que movimentam milhões de toneladas de alimentos para milhões de consumidores, seria definidamente a solução, foi admitida a lacuna crescente entre o sistema alimentar atual e os bilhões de pessoas para os quais ela foi aparentemente criada para servir.

Até o fim do século XX, o sistema alimentar moderno era celebrado como um trunfo da humanidade. Produzíamos mais carne, mais frutas, mais grãos, mais hortaliças do que antes, e mais baratos do que nunca. Mesmo com reclamações do uso indiscriminado de insumos químicos, ou da exploração de imigrantes, ou da falta de sabor desses alimentos, a maioria agradeceu os baixos preços e a abundância que os libertou da fome e tornou o dia a dia mais prático.

No entanto, as mesmas cadeias de abastecimento que disponibilizam hortifrútis e carnes baratas também criaram oportunidades perfeitas para surtos de Escherichia coli e Salmonella e variedades de gripe aviária que podem gerar uma nova pandemia global. E, apesar de toda essa

7 Projeto de Lei que institui a Política Nacional de Incentivo à Formação de Bancos Comunitários de Sementes e Mudas de Variedades e Cultivares Locais, Tradicionais ou Crioulos.

8 A proposta, que cria a Política Nacional de Incentivo à Formação de Bancos Comunitários de Sementes e Mudas de Variedades e Cultivares Locais, Tradicionais ou Crioulos, agora será analisada pelas comissões de Meio Ambiente; e de Constituição e Justiça. 
produtividade milagrosa, quase um bilhão de pessoas continuam com insegurança alimentar, ou seja, falta de disponibilidade e de acesso aos alimentos (Roberts, 2009). Além disso, a degradação do meio ambiente a esse tipo de produção não deixa claro como conseguiremos alimentar as 10 bilhões de pessoas esperadas para meados deste século e como os níveis atuais de produção poderão ser mantidos.

A questão da segurança alimentar tem sido uma discussão recorrente em diversas nações. Em 2000, foram estabelecidos oito Objetivos de Desenvolvimento do Milênio (ODM) a serem alcançados até 2015 pelos países signatários durante a Declaração do Milênio das Nações Unidas. O primeiro desses objetivos foi acabar com a pobreza extrema e a fome (MDG, 2010). O governo federal brasileiro criou, em 2003, o Programa Fome Zero, que visa ampliar o acesso à alimentação adequada para populações de baixa renda e fortalecer a agricultura familiar (CONSEA, 2009). E em 15 de setembro de 2006, nosso governo cria o Sistema Nacional de Segurança Alimentar e Nutricional, Lei 11.346, a fim de assegurar o direito humano à alimentação (Brasil, 2006).

$\mathrm{O}$ ato de comer, que é um dos alicerces de nossas tradições sociais, familiares e rituais, regrediu a um ato de irritação, pressa e culpa. O próprio significado do alimento e alimentação está sendo transformado. Antes era um elemento central para a manutenção da estrutura social e da tradição, e hoje está sendo extorquido pela cultura alimentar globalizada, na qual o custo e a conveniência são dominantes e a refeição social tornou-se obsoleta.

Boa parte do mundo em desenvolvimento ainda está se deparando com grandes desafios em termos de segurança alimentar. Em muitos casos não há estradas e ferrovias, depósitos e infra-estrutura para distribuir alimentos a todos consumidores que deles precisam.

Hoje é mais barato e fácil obter alimentos do que em qualquer época da história da humanidade. Porém, um sétimo da população (900 milhões de pessoas) está desnutrida; mais de um bilhão sofre de deficiências crônicas de micronutrientes; e quase metade da população mundial está obesa. Essa estatística é a prova de que a economia alimentar moderna é, na verdade, um fracasso. A insegurança alimentar só será rompida quando tiverem solucionados os problemas políticos e econômicos dos países (Roberts, 2009). 
Até hoje, somente Cuba fez em esforço sério para remodelar sua economia alimentar de acordo com um modelo sustentável. No início da década de 1990, o petróleo e insumos agrícolas que Moscou fornecia em troca de açúcar e frutas chegaram ao fim. Cuba viu-se tentando alimentar 10 milhões de habitantes, tratores ficaram ociosos, os campos repletos de ervas daninhas, e o gado, que se alimentava de grãos importados, voltou ao pasto. O desespero levou a desindustrializar seu modelo alimentar, tornando-o menos mecanizado, menos dependente de insumos químicos e centrado em alimentos voltados ao consumo local. As fazendas estatais foram divididas em cooperativas e trabalhadores foram realocados de empregos urbanos para trabalhar na agricultura. Nesse ínterim, as universidades e centros de pesquisa descobriam meios de substituir os insumos agrícolas industriais e adaptaram inúmeros métodos de agricultura agroecológica. E, embora ainda careçam de carne e laticínios, o país lidera em desenvolvimento nas categorias relacionadas a nutrição e segurança alimentar (Roberts, 2009).

\section{Consideraçồes finais}

Nos últimos trinta anos, a busca por um novo modelo de desenvolvimento tomou a forma de um intenso debate sobre o potencial de integração dos objetivos de desenvolvimento social, econômico e ecológico, dentro de um contexto geral de planejamento. A abordagem do desenvolvimento local ganhou destaque, nas últimas décadas, frente aos desafios impostos pela nova dinâmica econômica. Ou seja, reestruturação produtiva, em que propostas administradas pelos governos locais e regionais procuram assegurar o desenvolvimento econômico de cidades e regiões. Assim, atualmente é quase unânime entender que tal reducionismo não pode ser aplicado sem que haja reflexão, sem se considerar a melhoria da qualidade de vida das pessoas, a segurança alimentar e a conservação do meio ambiente.

Os recursos genéticos passaram a ser vistos como matéria-prima para o melhoramento genético realizado por instituições de pesquisa. $O$ valor econômico e utilitário desses recursos subestimou o valor cultural e identitário que tem para os agricultores e as comunidades locais. Precisamos reconhecer que o que aconteceu com nosso sistema alimentar e conosco 
não foi um processo aleatório e inevitável. As transformações deste sistema foram intencionais, impulsionadas e moldadas pela a poderosa força de mercado, produto de bilhões de decisões humanas. E, se muitas dessas decisões são tomadas em contextos além de nosso controle, muitas são tomadas bem perto, em nossa região, nossa comunidade, e até em nossa cozinha.

Diante do exposto no texto, é possível reconhecer que as transformações nos modos de vida e nos hábitos alimentares em escala individual e coletiva têm potencial de promover melhorias para o estado nutricional e de saúde, bem como de influenciar a relação econômica entre pequenos produtores e o consumidor final. Com base nesse reconhecimento, fomentar novas formas de favorecimento da aproximação desses dois segmentos sociais tem se mostrado de significativo interesse governamental.

Dentre os instrumentos que se apresentam como possíveis alternativas de ação, a etnobotânica mostra-se capaz de exercer papel fundamental na definição de perfis seletivos de alimentos locais e regionais que fazem parte do sistema de conhecimento tradicional regional. Esses perfis podem promover a visibilidade do etnoconhecimento sobre o acervo vegetal local, permitindo a emergência de novas perspectivas socioambientais aos produtores, em uma reconfiguração do processo produtivo baseado na ampliação do reconhecimento desse etnoconhecimento.

A premissa metodológica da etnobotânica é registrar quais as espécies são consumidas por cada grupo, em um determinado contexto cultural e geográfico, como conservam as plantas em seu próprio local e como averiguam seus sistemas de manejo específico. Estes dados podem auxiliar em programas de conservação de recursos e seu consequente uso sustentável. Também aumentam a diversidade de alimentos que consumimos, lembrando que a base alimentar do mundo usa poucas espécies e há um risco iminente, caso ocorra alguma doença ou catástrofe que pode comprometer a sobrevivência humana.

Com base nesse saber reconhecido, ações para o incentivo e favorecimento de maior diversificação do uso de plantas alimentícias não só despontam como uma alternativa econômica para o produtor rural, mas também ampliam os conhecimentos específicos sobre tais vegetais, surgindo como novos pratos e sabores a serem apresentados e oferecidos em restaurantes e hotéis, dando ainda mais reconhecimento e valorização aos produtos locais. 
A relevância sobre estudos de etnobotânica é visível, pois além de possibilitar a valorização do conhecimento local, busca encontrar estratégias que permitam colocar em diálogo os saberes científicos disciplinares com os saberes locais culturalmente mantidos. A visibilidade de todo esse acervo tem muito a contribuir para o desenvolvimento de alternativas sustentáveis de uso e gerenciamento de recursos naturais. Contudo, para a concretização de tais medidas é preciso estabelecer uma relação de confiança, reciprocidade e respeito mútuo no processo de pesquisa. Há que se valorizar a aproximação, a abordagem ética e a participação como parte fundamental para o surgimento de uma parceria que pode render muitos frutos, tanto para a ciência como para as populações produtoras envolvidas.

A diversidade de plantas, dentre elas as utilizadas para a alimentação, deveria ser protegida para garantir segurança alimentar da humanidade. Dessa forma, a investigação dos modos de vida e os padrões alimentares podem nos ajudar a elucidar riscos, benefícios e tendências para o futuro da segurança alimentar.

\section{Referências}

ADAS, M. A. Fome: crise ou escândalo? São Paulo: Editora Moderna, 1988.

ALBUQUERQUE, U. P. Introdução à Etnobotânica. Rio de Janeiro: Interciência, 2005.

ALISSON, E. Perda da biodiversidade é problema global. Agência FAPESP, 2013. Disponível em: http://agencia.fapesp.br/17544. Acesso em: 10 jun. 2014.

ALMEIDA, M. G. "Cultura ecológica e biodiversidade". Mercator - Revista de Geografia da UFC, n. 3, pp. 71-82, Ceará, 2003.

AMOROZO, M. C. M. Sistemas agrícolas tradicionais e a conservação da agrobiodiversidade. 2002. Disponível em: http//:www.ambiente.sp.gov. br/ea/adm/admmarqs/MariaA.pdf. Acesso em: 03 jun. 2014.

- "Construindo a sustentabilidade: biodiversidade em paisagens agrícolas e a contribuição da etnobiologia”. In: ALBUQUERQUE, U. 
P. et al. (eds.). Povos e paisagens: etnobiologia, etnoecologia e biodiversidade no Brasil. Recife: NUPEEA/UFRPE, 2007.

BANDEIRA, F. S. F. "Construindo uma epistemologia do conhecimento tradicional: problemas e perspectivas". In: COSTA-NETO, E. M. e SOUTO, F. J. B. Anais do I Encontro Baiano de Etnobiologia e Etnoecologia. Feira de Santana: UEFS, 2001, pp. 109-33.

BERKES, F. Sacred Ecology: traditional ecological knowledge and resource management. Philadelphia: Taylor \& Francis, 1999.

BRANQUINHO, F. O poder das ervas na sabedoria popular e no saber científico. Rio de Janeiro: Ed. Mauad, 2007.

BRASIL. "Lei n. ${ }^{\circ}$ 11.346, 15 de setembro de 2006". Cria o Sistema Nacional de Segurança. Alimentar e Nutricional - SISAN com vistas a assegurar o direito humano à alimentação adequada e dá outras providências. Disponível em: http://www.planalto.gov.br/ccivil_03/_ato20042006/2006/lei/111346.htm. Acesso em: 15 jun. 2014.

. "Lei no 11.326, 24 de julho de 2006". Estabelece as diretrizes para a formulação da Política Nacional da Agricultura Familiar e Empreendimentos Familiares Rurais. Disponível em: http://www.planalto.gov.br/ccivil_03/_ato2004-2006/2006/lei/111326.htm. Acesso em: 25 jun. 2014.

CASTRO, C. F. A. Biodiversidade e quintais. Rio de Janeiro: FASE, 1995.

CONSEA. 2009. Construção do Sistema e da Política Nacional de Segurança Alimentar e Nutricional: a experiência brasileira. Disponível em: https:// www.fao.org.br/download/Seguranca_Alimentar_Portugues.pdf. Acesso em: 30 maio 2014.

COUPE, S. e LEWINS, R. Negotiating the seed treaty. Grã-Bretanha: Pratical Action Publishing, 2007.

CORADIN, L. "Parentes silvestres e variedades crioulas das espécies de plantas cultivadas no país". In: (org.). Parentes silvestres de plantas cultivadas. Brasília: Ministério do Meio Ambiente, 2006.

CULTRERA, M. Estudo etnobotânico de plantas alimentares cultivadas por moradores da periferia de Santo Antônio de Leverger, MT (dissertação). UNESP, 2008. 
ELISABETSKY, E. Etnofarmacologia. Campinas: Ciência \& Cultura, 2003.

EUROMONITOR INTERNATIONAL CONSULTING. Strategic business-to-business and consumer research. 2014. Disponível em: http:// www.euromonitor.com/consulting. Acesso em: 19 jun. 2014.

FAO. Organização das Nações Unidas para alimentação e agricultura. Disponível em: https://www.fao.org.br/. Acesso em: 30 maio 2014.

GLOYD, S. Introduction to Global Health: disparities, determinants, policies and outcomes. 2014. Disponível em: http://www.washington.edu/students/crscat/gh.html. Acesso em: 16 jun. 2014.

GUARIM-NETO, G. e CARNIELLO. M. A. "Etnoconhecimento e saber local: um olhar sobre populações humanas e os recursos vegetais”. In: ALBUQUERQUE, U. P. et al. (eds.). Povos e paisagens: etnobiologia, etnoecologia e biodiversidade no Brasil. Recife: NUPEEA/UFRPE, 2007.

KINUPP, V. L. Plantas alimentícias não convencionais da região metropolitana de Porto Alegre, RS (tese). UFRS, 2007.

MAPA. Ministério da Agricultura, Pecuária e Abastecimento. Disponível em: http://www.agricultura.gov.br/. Acesso em: 03 jun. 2014.

MAXWELL, S. e SMITH, M. "Household food security: a conceptual review”. In: e FRANKENBERGER, R. T. (eds.). Household food security: concepts, indicators, measurements: a technical review. Nova Iorque: Unicef ; Roma: IFAD, 1992.

MILLENIUM DEVELOPMENT GOALS (MDG). 2010. Disponível em: http://www.un.org/spanish/millenniumgoals/pdf/MDG_Report_2010_SP.pdf. Acesso em: 05 jun. 2014.

MING, L. C. et al. (orgs.). Agrobiodiversidade no Brasil: experiências e caminhos da pesquisa. Recife: NUPEEA, 2010.

MOLINA-MARTÍNEZ, N. Etnobotánica de quelites en el sistema milpa en Zoatecpan, una comunidad indígena de la Sierra Norte de Puebla. México: UNAM, 2000.

OTAVIANO, C. Muito além da tecnologia: os impactos da Revolução Verde. 2010. Disponível em: http://comciencia.br/comciencia/?section $=8 \&$ edicao $=58 \&$ id $=730$. Acesso em: 04 maio 2014. 
PIRRELLI, M. A. S. Conhecimento tradicional e currículo multicultural: notas com base em uma experiência com estudantes indígenas Kaiowá/Guarani. Bauru: Ciência \& Educação, 2008.

POLLAN, M. O dilema do onívoro. São Paulo: Intrínseca, 2007. . Em defesa da comida: um manifesto. Rio de Janeiro: Intrínseca, 2008.

RAPOPORT, E. H. et al. Malezas comestibles del Cono Sur y otras partes del planeta. Rio Negro: Instituto Nacional de Tecnología Agropecuaria Universidad Nacional del Comahue Consejo Nacional de Investigaciones Científicas y Técnicas Secretaría de Ambiente y Desarrollo Sustentable Fundación Normatil, 2009.

REZENDE-SILVA, S. "Comunidades quilombolas e a política ambiental e territorial na mata atlântica”. Geografia em Questão, v. 5, n. 1, pp. 4765, 2012.

ROBERTS, P. O fim dos alimentos. Rio de Janeiro: Elsevier, 2009.

SANTILLI, J. F. R. Agrobiodiversidade e direitos dos agricultores (tese). Pontifícia Universidade Católica do Paraná, 2009. 


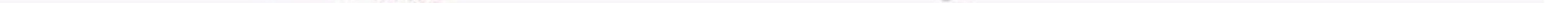




\title{
CAPÍTULO IV \\ Plantas medicinais: \\ saberes tradicionais e o sistema de saúde
}

\author{
Marcelo Guerra Santos \\ Ana Cecília Bezerra Carvalho
}

\section{0 diálogo entre os saberes tradicionais e os saberes científicos}

Há tempos o homem recorre à natureza em busca do alívio de suas dores do corpo e da alma, em especial às plantas. Grande parte desse conhecimento sobre as propriedades medicinais das plantas foi construído de forma empírica. A observação da natureza, do comportamento dos animais que usam as plantas, assim como de plantas enteógenas (que estabelecem comunicações com divindades e espíritos), utilizadas principalmente pelos líderes religiosos de uma comunidade, também foram (e são) importantes nesse processo de acumulação do conhecimento. Esses saberes tradicionais são repassados pela oralidade através das gerações, salvo em publicações de cunho etnográfico e/ou etnobiológico que visam registrá-los (Di Stasi, 1996). Muitos cientistas estão preocupados (e com razão) com as elevadas taxas de extinção de espécies, mas há pouco destaque na extinção dos saberes tradicionais, que também é um dos elementos da biodiversidade. Dentro de diversas comunidades, os mais jovens já não se interessam pelos "segredos da natureza", como faziam os seus antepassados, e muitos deles são seduzidos pela tecnologia dos centros urbanos (Begossi et al., 2006).

Atualmente, há um grande interesse dos etnobotânicos no estudo e publicação dos saberes tradicionais, entre eles o uso das plantas medicinais (Oliveira et al., 2009). Desse modo, cria-se a expectativa de um diálogo entre os saberes tradicionais e os saberes científicos, onde dúvidas da ciência são respondidas pelo conhecimento popular e vice-versa. A 
experiência que determinadas comunidades possuem em utilizar, cultivar, coletar e preparar as plantas medicinais pode ser esclarecedora para a ciência, do mesmo modo que o conhecimento científico adquirido pelos cientistas, advindo do desenvolvimento tecnológico, é um importante retorno na prática cotidiana das populações tradicionais, destacando a detecção de substâncias tóxicas ou a validação do uso de certas plantas medicinais. Acima de tudo, é preciso tolerância e respeito aos diferentes conhecimentos e à maneira como eles foram construídos.

O Brasil possui uma enorme diversidade, não só biológica, mas também cultural. Essa última constituída por diferentes contribuições, predominantemente da matriz africana, europeia e indígena. Como reflexo, tem-se uma miscigenação de interações com os elementos biológicos nativos e exóticos, um cenário fértil para a Etnofarmacologia (Elisabetsky, 2003).

Ainda há dúvidas sobre a importância dos estudos etnodirigidos versus estudos aleatórios na seleção de plantas para a descoberta de novos fármacos. Contudo, para certas doenças, os relatos etnofarmacológicos e etnobotânicos de populações tradicionais têm se mostrado um valioso atalho (Khafagi e Keweder, 2000; Elisabetsky, 2003; Albuquerque et al., 2014).

Albuquerque e Hanazaki (2006) apontam alguns fatores limitantes aos estudos etnodirigidos, tais como: a dificuldade de coletar informações fidedignas dos informantes; o fato do uso de plantas em diferentes culturas encontrar-se sempre associado, em maior ou menor grau, a componentes mágico-religiosos; e a existência de questões éticas que envolvem acesso ao conhecimento tradicional associado ao uso da biodiversidade.

Albuquerque et al. (2014) fazem uma reflexão sobre a abordagem etnofarmacológica na descoberta e no desenvolvimento de novas drogas a partir das plantas medicinais. Os autores alertam para os problemas nos desenhos experimentais e na coleta de dados nos estudos de etnofarmacologia, incluindo a má interpretação da importância que as plantas medicinais possuem no sistema médico de populações tradicionais ou locais. Essas fragilidades metodológicas, segundo os autores, podem comprometer a bioprospecção de novos medicamentos.

Mesmo com os problemas supracitados, a abordagem etnofarmacológica é um caminho importante no desenvolvimento de fitoterápicos, sendo importante que a busca por esses novos produtos esteja sempre atrelada a um melhor desenvolvimento humano, à conservação da natureza e ao uso sustentável dos recursos dos ecossistemas (Moran et al., 2001). 


\section{As plantas medicinais no Sistema Único de Saúde (SUS) e polí- ticas públicas}

Existem políticas e acordos nacionais e internacionais objetivando o uso correto de plantas medicinais e fitoterápicos, com base em preceitos de segurança, eficácia, qualidade e desenvolvimento ambiental sustentável.

A Organização Mundial da Saúde (OMS), na Conferência Internacional sobre Atenção Primária em Saúde, realizada em Alma-Ata (República do Cazaquistão), em 1978, publicou um documento orientando os países-membros a protegerem e promoverem a saúde dos povos do mundo, dentre outras coisas, pela formulação de políticas e regulamentações nacionais, referentes ao uso de remédios populares de eficácia comprovada (OMS, 1979). Desde então, a OMS vem publicando diversos documentos relacionados à qualidade, segurança, eficácia, tradicionalidade e monografias de plantas medicinais e fitoterápicos para orientar os países na regulação desses produtos.

A Convenção sobre Diversidade Biológica (CDB), promovida em 2002 pela Organização das Nações Unidas (ONU), foi o primeiro acordo global com cobertura ampla sobre os aspectos da biodiversidade, reconhecendo-a como preocupação comum da humanidade e parte integrante dos processos de desenvolvimento. Seus principais objetivos são a conservação da diversidade biológica, a utilização sustentável de seus componentes e a divisão justa e equitativa dos benefícios obtidos da utilização dos recursos genéticos, incluindo os vegetais (ONU, 2002).

A Constituição Federal brasileira determina que seja competência da União a elaboração e execução de políticas públicas para o desenvolvimento econômico e social do país (Brasil, 1988). Diversas políticas públicas brasileiras referem-se a ações em plantas medicinais e fitoterápicos. A Política Nacional de Medicamentos, na diretriz "Desenvolvimento científico e tecnológico", prevê a continuidade e expansão do apoio a pesquisas para o aproveitamento do potencial terapêutico da flora nacional com certificação de sua segurança e eficácia (Brasil, 1998).

A Política Nacional de Assistência Farmacêutica envolve um conjunto de ações voltadas à promoção, proteção e recuperação da saúde, além da garantia dos princípios da equidade, universalidade e integralidade no acesso. Traz, em seus eixos estratégicos, a necessidade de definição e 
pactuação de ações intersetoriais para utilização de plantas medicinais e fitoterápicos no processo de atenção à saúde, com respeito aos conhecimentos tradicionais incorporados, embasamento científico, com adoção de políticas de geração de emprego e renda, qualificação e fixação de produtores, envolvimento dos trabalhadores em saúde no processo de incorporação da fitoterapia e incentivo à produção nacional, com a utilização da biodiversidade existente no país (Brasil, 2004).

Em 2006, duas políticas foram publicadas, uma por decreto e outra por portaria, pelo Ministério da Saúde, ressaltando a utilização de plantas medicinais e fitoterápicos. A primeira foi a Política Nacional de Práticas Integrativas e Complementares (PNPIC), no Sistema Único de Saúde (SUS). Elaborada com o objetivo de oferecer à população serviços e produtos relacionados à fitoterapia, acupuntura, homeopatia e termalismo social no SUS, a PNPIC garante a integralidade na atenção à saúde por serviços que antes só eram acessíveis em práticas de cunho privado, abrangendo ações a serem implementadas no SUS e nos diversos órgãos da saúde relacionados, tais como Ministério da Saúde, secretarias de saúde municipais e estaduais, Anvisa (Agência Nacional de Vigilância Sanitária) e Fundação Oswaldo Cruz (Fiocruz) (Brasil, 2006a).

Os objetivos da PNPIC são: 1) incorporar e implementar as práticas integrativas no SUS, com ênfase na prevenção de agravos e da promoção e recuperação da saúde; 2) contribuir para o aumento da resolubilidade do Sistema e ampliação do acesso às Práticas Integrativas e Complementares (PIC), garantindo segurança, eficácia e qualidade no uso; 3) promover a racionalização das ações de saúde, estimulando alternativas inovadoras e socialmente contributivas ao desenvolvimento sustentável da comunidade; 4) estimular ações referentes ao controle/participação social (Brasil, 2006b). ${ }^{1}$ A PNPIC-SUS deverá atuar como um estímulo na busca de novas plantas medicinais a serem disponibilizadas no SUS. Nesse sentido, tornam-se imperativas ações que incentivem a pesquisa e o desenvolvimento de plantas medicinais no Brasil, sendo louvável o diálogo entre os cientistas e os conhecimentos etnofarmacológicos das populações tradicionais, principalmente das plantas nativas (Elisabetsky, 2003).

1 Ver Brasil, 2006a. 
Dentre as diretrizes estabelecidas na PNPIC estão: a estruturação e o fortalecimento da atenção em PIC, no SUS, mediante incentivos à inserção em todos os níveis de atenção com ênfase na atenção básica; provimento do acesso a medicamentos homeopáticos e fitoterápicos na perspectiva da ampliação da produção pública, assegurando as especificidades da assistência farmacêutica nestes âmbitos na regulamentação sanitária; incentivo à pesquisa em PIC, avaliando eficácia, efetividade e segurança dos cuidados prestados; e a garantia do monitoramento da qualidade dos fitoterápicos pelo Sistema Nacional de Vigilância Sanitária (SNVS).

Além da fitoterapia, fazem parte da PNPIC, atualmente, outras 28 práticas, desde quando foram incluídas, em março de 2018: a apiterapia, aromaterapia, bioenergética, constelação familiar, cromoterapia, geoterapia, hipnoterapia, imposição de mãos, ozonioterapia e terapia de florais. Estas se juntaram às outras práticas integrativas já presentes no SUS: ayurveda, homeopatia, medicina tradicional chinesa, medicina antroposófica, arteterapia, biodança, dança circular, meditação, musicoterapia, naturopatia, osteopatia, quiropraxia, reflexoterapia, reiki, shantala, terapia comunitária integrativa, termalismo social/crenoterapia e ioga. Mais informações podem ser obtidas por meio do Glossário Temático Práticas Integrativas e Complementares em Saúde (Brasil, 2018).

A outra política publicada no mesmo ano da PNPIC, porém envolvendo uma escala maior de atores, foi a Política Nacional de Plantas Medicinais e Fitoterápicos (PNPMF), em 23 de junho 2006, por meio do Decreto Presidencial n. ${ }^{\circ}$ 5.813. Essa política, de caráter interministerial, envolve, além do Ministério da Saúde, Anvisa, Fiocruz, Casa Civil da Presidência da República, oito Ministérios: Ministério do Meio Ambiente (MMA); Ministério da Agricultura, Pecuária e Abastecimento (MAPA); Ministério do Desenvolvimento Agrário (MDA); Ministério do Desenvolvimento, Indústria e Comércio Exterior (MDIC); Ministério da Integração Nacional (MI); Ministério da Ciência e Tecnologia (MCT); Ministério do Desenvolvimento Social e Combate à Fome (MDS); e Ministério da Cultura (MinC) (Brasil, 2006c).

A PNPMF estabeleceu as linhas de ação prioritárias para o uso racional de plantas medicinais e fitoterápicos, com o objetivo de consolidar as iniciativas relevantes no país e as recomendações nacionais e internacionais sobre o tema. A expectativa é minimizar a dependência tecnológica 
do Brasil no setor e estabelecer uma posição de destaque do país no cenário internacional (Brasil, 2006c).

A PNPMF é parte essencial das políticas públicas de saúde, meio ambiente, desenvolvimento econômico e social, objetivando implantar ações transversais capazes de promover melhorias na qualidade de vida da população brasileira. Seu objetivo geral é garantir ao povo o acesso seguro e o uso racional de plantas medicinais e fitoterápicos, promovendo o uso sustentável da biodiversidade e o desenvolvimento da cadeia produtiva e da indústria nacional (Brasil, 2006c).

Seguindo-se à publicação da PNPIC e PNPMF, como uma das primeiras ações decorrentes delas, ocorreu a oficialização do uso de medicamentos fitoterápicos obtidos de Mikania glomerata e Maytenus officinalis (tabela 1), no SUS, pela sua inserção no elenco de referência de medicamentos e insumos complementares para a assistência farmacêutica na atenção básica em Saúde, por meio da Portaria 3237/2007 (Brasil, 2007). Essa Portaria já foi republicada algumas vezes, sendo inseridos dez novos fitoterápicos em 2012, por meio da Portaria 533 GM/MS: Cynara scolymus, Schinus terebenthifolius, Frangula purshiana, Harpagophytum procumbens, Glycine max, Uncaria tomentosa, Salix alba, Aloe vera, Mentha x piperita, Plantago ovata e diversas formas farmacêuticas definidas no documento (Brasil, 2014b). ${ }^{2}$

Em 2008, foi publicado o Programa e instituído o Comitê Nacional da PNPMF, com objetivo de monitoramento e avaliação das ações a serem realizadas. Fazem parte do Comitê representantes do governo - Casa Civil, Ministério da Agricultura, Pecuária e Abastecimento (MAPA), Ministério da Ciência e Tecnologia (MCT), Ministério do Desenvolvimento Agrário (MDA), Ministério do Desenvolvimento, Indústria e Comércio Exterior (MDIC), Ministério do Desenvolvimento Social e Combate à Fome (MDS), Ministério da Educação (MEC), Ministério da Integração Nacional (MI), Ministério da Cultura (MinC), Ministério do Meio Ambiente (MMA), Ministério da Saúde (MS), Anvisa e Fundação Oswaldo Cruz (Fiocruz); e da sociedade civil - representantes da agricultura familiar, da Agricultura, dos biomas Amazônia, Caatinga, Cerrado, Mata Atlântica, Ecossistemas Costeiros e Marinhos, Pampa e Pantanal, representantes da indústria, de farmácias de manipulação, da pesquisa, repre-

\footnotetext{
${ }^{2}$ Ver tabela 1.
} 
sentantes de povos e comunidades tradicionais e representantes dos serviços públicos de saúde em nível municipal e estadual (Brasil, 2008).

O PNPMF tem o objetivo de fomentar pesquisa, desenvolvimento tecnológico e inovação com base na biodiversidade brasileira, abrangendo espécies vegetais nativas e exóticas adaptadas (naturalizadas), priorizando as necessidades epidemiológicas da população.

Dentre as diretrizes da PNPMF no âmbito das comunidades tradicionais, destacam-se: 1) Promoção e reconhecimento das práticas populares de uso de plantas medicinais e remédios caseiros; 2) Promoção do uso sustentável da biodiversidade e a repartição dos benefícios derivados do uso dos conhecimentos tradicionais associados e do patrimônio genético; 3) Promoção da inclusão da agricultura familiar nas cadeias e nos arranjos produtivos das plantas medicinais, insumos e fitoterápicos.

Em 2009, o MS publicou a Relação Nacional de Plantas Medicinais de interesse ao SUS (RENISUS), como uma lista de espécies vegetais com potencial de avançar nas etapas da cadeia produtiva e de gerar produtos de interesse ao SUS (Brasil, 2009). Ou seja, o Ministério da Saúde não afirma que o uso dessas plantas é seguro e eficaz, mas que são de interesse para estudos e desenvolvimento de produtos para o SUS. Assim, a finalidade da RENISUS é subsidiar o desenvolvimento de toda cadeia produtiva, inclusive as ações que serão desenvolvidas também pelos outros ministérios participantes da PNPMF, relacionadas à regulamentação, cultivo/ manejo, produção, comercialização e dispensação de plantas medicinais e fitoterápicos. Essa lista tem ainda a função de orientar estudos e pesquisas que possam subsidiar a elaboração da Relação Nacional de Plantas Medicinais e Fitoterápicos (RENAFITO), bem como o desenvolvimento e a inovação na área de plantas medicinais e fitoterápicos (Brasil, 2009, Nascimento Junior et al., 2010).

A RENISUS apresenta 84 espécies vegetais (tabela 2). Essa lista foi construída a partir de plantas já utilizadas nos serviços de saúde estaduais e municipais, oriundas do conhecimento tradicional e popular e com alguns estudos químicos, toxicológicos e farmacológicos disponíveis. Esses estudos, porém, não são completos para a maioria das plantas, conforme as exigências sanitárias, precisando ser complementados. Dessa lista, 42 espécies são nativas do Brasil, 26 são exóticas, treze naturalizadas e três cultivadas (tabela 2). Considerando que a flora do Brasil possui mais de 46 mil espécies - incluindo algas, fungos, briófitas, pteridófitas, gimnos- 
permas e angiospermas (Flora do Brasil 2020) -, o conjunto de espécies nativas da lista da RENISUS representa apenas 0,09\% desse total. Apesar do crescimento dos estudos etnobotânicos no Brasil, ${ }^{3}$ ainda são muito tímidos os estudos etnodirigidos para o conhecimento medicinal de nossa flora. Além disso, em diversos estudos etnofarmacológicos conduzidos, há problemas metodológicos que dificultam a descoberta e o desenvolvimento de novos medicamentos. ${ }^{4}$ De outro lado, faltam estudos de padronização química, como também estudos clínicos, a maioria concentrando-se em estudos de farmacologia ou toxicologia não clínica.

Outras políticas públicas lançadas posteriormente, como o Programa Nacional de Fomento à Produção Pública e Inovação no Complexo Industrial da Saúde no âmbito do SUS, publicado pela Portaria 374/2008, também trouxeram linhas de incentivo à PNPMF.

\section{Plantas medicinais e fitoterápicos}

As plantas medicinais podem ser utilizadas frescas ("in natura"), secas (droga vegetal) ou para a preparação de fitoterápicos manipulados ou industrializados. As plantas medicinais frescas ou secas, apesar de serem utilizadas como terapêuticas, não são medicamentos como muitos podem pensar, pois os medicamentos precisam ser tecnicamente elaborados, devendo estar disponíveis em preparações farmacêuticas, como rasuras, comprimidos, cápsulas ou xaropes. Os medicamentos feitos com plantas, os chamados fitoterápicos, devem passar por um rigoroso processo de produção e controle de qualidade determinados pela Anvisa.

Após a publicação da PNPMF e da PNPIC, a Anvisa republicou todos os seus regulamentos relacionados a fitoterápicos, de modo a atender os objetivos propostos nessas duas políticas. Assim, recentemente foi republicada a norma de registro de fitoterápicos, como Resolução da Diretoria Colegiada (RDC) n. ${ }^{\circ} 26$ de 13 de maio de 2014. Essa norma divide os fitoterápicos em duas categorias: Medicamentos Fitoterápicos (MF) e Produtos Tradicionais Fitoterápicos (PTF), de forma semelhante aos princi-

\footnotetext{
3 Ver Oliveira et al., 2009.

${ }^{4}$ Ver Albuquerque et al., 2014.
} 
pais países do mundo que regulam fitoterápicos, como os da comunidade europeia. Para os primeiros, MF, a comprovação da segurança e eficácia se dá por meio de estudos clínicos padronizados, da mesma forma para qualquer medicamento sintético novo a ser registrado no país. Já os PTF são registrados por meio da apresentação de dados que comprovem o uso seguro e efetivo no ser humano, por um período mínimo de trinta anos. A norma que regulamenta o registro foi publicada acompanhada por um guia (IN 04/2014) que orienta toda a produção e registro de fitoterápicos (Brasil, 2014a).

Internacionalmente, essas duas formas são permitidas para regulamentar fitoterápicos, havendo situações em que cada uma é mais apropriada. Para um extrato padronizado, ou seja, sempre produzido nas mesmas condições, com matéria-prima padronizada e perfil de constituintes químicos semelhantes, o estudo clínico é muito apropriado, considerando que avalia se naquelas condições o extrato possui segurança e eficácia. Porém, um estudo clínico de extrato de guaco (Mikania laevigata) padronizado, coletado sob determinadas condições (de luz, umidade, altitude, pressão, hora da coleta) no Sudoeste do Brasil e processado de forma diferente de outro coletado no Nordeste, não prova que este último é seguro e eficaz, considerando que o seu perfil químico pode ser completamente diferente, e assim, suas propriedades farmacológicas. O estudo clínico sempre prova condições daquele produto testado. Por outro lado, se existem diversas citações na literatura que determinada planta, em certas condições, coletada em diferentes regiões, não apresenta efeitos graves conhecidos e é efetiva para curar determinadas doenças, consegue-se extrapolar essas informações para os extratos semelhantes. Assim, comprova-se a utilização tradicional para registro de fitoterápicos. Deve-se observar que o registro por tradicionalidade é indicado para doenças de baixa gravidade, que sejam pensadas para utilização sem necessidade de acompanhamento médico, conforme a tradição.

Essas normas também criaram a notificação de PTF para aquelas formulações que se encontrem dispostas no Formulário de Fitoterápicos da Farmacopeia Brasileira e que possuam monografias de controle de qualidade em farmacopeia oficial, que são as dispostas na RDC 37/09. A notificação é uma forma de liberação mais rápida do fitoterápico, sendo necessário, para isso, que a empresa comprove que possui as boas práticas de fabricação e que siga todos os requisitos estabelecidos pela Anvisa 
quanto à qualidade e informações a serem disponibilizadas sobre o produto (Brasil, 2014).

Com essas normas, a Anvisa pretendeu atualizar o marco regulatório em consonância com as normas internacionais mais modernas, que reconhecem a utilização tradicional de fitoterápicos como uma forma segura e eficaz de liberação do seu uso. Também foi publicado recentemente o regulamento para pós-registro de fitoterápicos, ou seja, as regras que devem ser seguidas quando é necessário fazer uma alteração em um fitoterápico registrado, por meio da RDC 38/2014 e da IN 05/2014. Concluindo a republicação do arcabouço legislativo, também foi republicado o registro simplificado de fitoterápicos, que é uma lista de informações que, desde que seguidas integralmente pela empresa, não precisa apresentar dados adicionais de segurança e eficácia, já que eles são previamente estabelecidos pela Anvisa; essa norma é a IN 02/2014 (Brasil, 2014).

Só podem produzir fitoterápicos industrializados empresas que sejam autorizadas pela vigilância sanitária. As regras para o estabelecimento que produzir MF, seguindo o que se chama Boas Práticas de Fabricação, estão estabelecidas pela RDC 17/2010; já para produzir PTF, a Anvisa publicou uma norma específica, a RDC 13/2013, que é mais simples e dedicada exclusivamente para a produção de fitoterápicos. A Anvisa também publicou uma norma específica orientando as empresas produtoras de matérias-primas que queiram trabalhar como fornecedoras de plantas para a indústria farmacêutica ou para farmácias de manipulação, a RDC 69/2014 (Brasil, 2014).

O Ministério da Saúde, por meio da Portaria 886, de 20 de abril de 2010, instituiu a "Farmácia Viva" no SUS, que deverá realizar todas as etapas, desde o cultivo, a coleta, o processamento, o armazenamento de plantas medicinais, a manipulação e a dispensação de preparações magistrais e oficinais de plantas medicinais e fitoterápicos (Brasil, 2010).

A produção de fitoterápicos em Farmácias Vivas foi regulamentada pela RDC 18/2013, que explicita como devem ser as Boas Práticas de Manipulação em Farmácias Vivas, farmácias públicas destinadas a distribuir fitoterápicos no SUS. Com a revisão e publicação de todos esses regulamentos, espera-se ter um arcabouço regulatório atualizado, harmonizado internacionalmente, de modo que se tenha, no mercado brasileiro, fitoterápicos seguros, eficazes e de qualidade a serem oferecidos à população (Brasil, 2013a). 
As regras publicadas para fabricação de fitoterápicos pela Anvisa ainda são muito rígidas, necessitando da implementação de um bom laboratório de controle de qualidade, que inclui, por exemplo, o controle microbiológico - obrigatoriedade de ter responsável técnico farmacêutico e a necessidade de equipe técnica especializada para produção de fitoterápicos. A Anvisa precisa agir dessa forma, pois, no Brasil, fitoterápicos são considerados medicamentos, os quais possuem todos os requisitos de produção estabelecidos em Lei, publicada pelo Congresso Nacional. Alterações maiores nas normas de fitoterápicos dependem de mudanças nas leis hoje instituídas, como a Lei 6.360 publicada em 1976 (Brasil, 2014).

Enquanto essas mudanças na legislação não são implementadas, a nova norma de registro da Anvisa, RDC 26/14, previu: "Não são objeto de registro ou notificação as preparações elaboradas pelos povos e comunidades tradicionais do país sem fins lucrativos e não industrializadas". Ou seja, as normas de registro de medicamentos industrializados da Anvisa são feitas para indústrias farmacêuticas e não para comunidades tradicionais, desde que estas não façam produção em grande escala e não comercializem os fitoterápicos produzidos.

Conforme essa orientação, as comunidades podem produzir fitoterápicos para uso próprio, em sua região, de forma não industrializada. A Anvisa pode fornecer essa orientação, conforme previsto no Art. 273 do Código Penal brasileiro. Contudo, até essa legislação precisaria ser modificada, pois, segundo ela, todos os produtores de fitoterápicos no Brasil teriam que ter autorização de funcionamento concedido pela Vigilância Sanitária.

\section{Cuidados no uso de plantas medicinais}

Um alerta importante no uso de plantas medicinais é a falsa ideia de que as plantas são remédios naturais e por isso não fazem mal à saúde. Isso não é verdadeiro! Algumas plantas são tóxicas ou possuem substâncias que, quando ingeridas em grande quantidade, podem provocar prejuízos à saúde, inclusive levando à morte.

Por isso, ao utilizar as plantas com finalidade terapêutica, deve-se estar atento a diferentes fatores, tais como: a indicação de seu uso; sua correta identificação; as condições de cultivo, coleta e armazenamento; forma 
de preparo, incluindo a parte da planta que deve ser utilizada; modo de administração; e se não há relato de efeitos adversos graves com o uso da planta (Paiva et al., 2009).

\section{Indicaçăo de uso}

Grande parte do conhecimento tradicional é repassado de forma oral e, nessa transferência, as informações podem ser perdidas ou mal interpretadas. Na maioria das vezes, são atribuídos a uma mesma planta diferentes usos medicinais, muitos deles para doenças completamente diferentes. É necessário sempre recorrer a um especialista local, aos $\operatorname{livros}^{5}$ ou ao sistema de saúde (caso a cidade tenha disponível práticas integrativas e complementares do SUS) para obter as informações corretas de uso.

\section{Correta identificaçăo}

Reconhecer de forma precisa uma determinada planta utilizada como medicinal é fundamental e muitas das vezes vital. Há muitas plantas tóxicas que parecem (ou podem parecer semelhantes a um leigo) com certas plantas medicinais. O reconhecimento tradicional das plantas é baseado em nomes populares, o que pode causar confusão. Uma determinada espécie pode receber diversos nomes, principalmente em diferentes regiões, ou várias espécies receberem um mesmo nome popular. Novamente ressalta-se a importância de um especialista local no reconhecimento e/ou na transmissão desse saber. Já os cientistas identificam as espécies através dos nomes científicos. Essa maneira de dar nomes às plantas é interessante, pois cada planta possui apenas um nome aceito pela comunidade científica internacional, que é escrito em latim ou latinizado. Dessa maneira, uma planta pode ser reconhecida em qualquer parte do mundo, independente do país onde esteja. Por exemplo, a espécie com o nome científico Cymbopogon citratus (DC.) Stapf. (Poaceae) pode ser conhecida popularmente no Brasil como capim-limão, erva-cidreira, capim-cidreira, capim-cheiroso,

5 Ver Lorenzi e Mattos, 2002 e Santos et al., 1988. 
capim-de-cheiro, grama-cidreira ou capim-santo, dependendo da região. É interessante perceber que, em certas comunidades que foram alvos de estudos etnobotânicos, pode ocorrer um sincretismo na nomenclatura das plantas, onde passam a ser utilizados pela população local tanto os nomes populares quanto parte dos científicos.

Aplicar um nome correto a uma planta, principalmente o científico, significa o acesso a muitas informações sobre ela, incluindo suas propriedades medicinais, tóxicas, distribuição geográfica, importância econômica, entre outras. Os passos para essa tarefa são: 1) coleta, herborização e depósito da exsicata em um herbário; 2) identificação do material botânico por um especialista. ${ }^{6}$

Atenção especial deve ser dada aos sinônimos, ou seja, nomes aplicados a uma espécie e que foram rejeitados devido à má aplicação ou diferença no julgamento taxonômico. Em muitos casos, uma espécie pode ter vários sinônimos, o que pode dificultar o entendimento do não taxonomista. Para citar um exemplo, em termos práticos, quando se realiza um levantamento bibliográfico sobre as propriedades medicinais de uma determinada espécie de planta, deve-se pesquisar não somente com o nome aceito na atualidade, mas também com os principais sinônimos (quando houver) daquela espécie. Deve-se lembrar que alguns dos sinônimos podem ter sido utilizados em publicações anteriores.

Para auxiliar nessa tarefa, há diversas bases de dados que oferecem a informação do nome aceito e dos sinônimos (quando for o caso), entre eles: The Plant List: a working list of all plant species (http://www.theplantlist.org), Tropicos (http://www.tropicos.org), The International Plant Names Index (http://www.ipni.org) e Flora do Brasil 2020 (http://floradobrasil.jbrj.gov.br).

\section{As condiçôes de cultivo, coleta e armazenamento}

As condições de cultivo das plantas medicinais podem interferir na quantidade e na qualidade das substâncias produzidas pelas plantas. Em algumas situações de cultivo, a substância com ação terapêutica pode não

\footnotetext{
6 Sobre processos de herborização de plantas medicinais, ver Di Stasi (1996).
} 
estar sendo produzida pela planta. Desse modo, ainda há muitas dúvidas dos produtores sobre a melhor forma de propagação, tipo de solo, clima e época de colheita (Furlan, 1996). Nesse sentido, a etnoagricultura - parte da etnobiologia que estuda a agricultura tradicional - pode ser uma importante aliada.

Alguns cuidados, porém, devem ser tomados ao se cultivar plantas medicinais. O primeiro deles é a escolha do local. Ele não deve estar exposto a poluentes, tais como fuligem de indústrias ou de carros, águas poluídas por agrotóxicos ou esgoto doméstico e industrial. Esses poluentes podem ser absorvidos ou estar aderidos nas plantas. Algumas plantas medicinais exigem técnicas de coleta adequadas, tais como época de maturação correta, hora do dia ideal (principalmente aquelas que são aromáticas), época do ano e até mesmo o modo de colheita. Deve-se consultar sempre os especialistas locais ou os manuais de cultivo de plantas medicinais para maiores esclarecimentos quanto ao correto procedimento. Boas referências são os trabalhos de Correa Júnior (1991), Furlan (1996) e Reis e Mariot (1999).

Outra etapa crucial é o armazenamento das plantas. Para isso, é importante uma completa e correta secagem do material vegetal. Esse procedimento evita reações químicas e ataque de microorganismos (bactérias e fungos). Posteriormente o material vegetal deve ser embalado e acondicionado em lugar arejado e de temperaturas amenas. Deve-se sempre conhecer a procedência das plantas medicinais que utilizamos no dia a dia.

No Brasil, a utilização de agrotóxicos em plantas medicinais é proibida, não existindo agrotóxicos aprovados para esse fim. Agrotóxicos utilizados em plantas podem ser extraídos e concentrados nos fitoterápicos, podendo causar reações adversas nos usuários.

\section{Forma de preparo e administraçăo}

Não adianta uma correta identificação, coleta e armazenamento da planta medicinal se a forma de preparo não for a recomendada. Existem diversas formas de preparo, desde um simples chá (feito por infusão ou decocção) até formulações mais elaboradas (Di Stasi, 1996; Lorenzi e Mattos, 2002; Santos et al., 1988). Nesse campo, há um terreno fértil a ser compartilhado entre os especialistas locais e os etnofarmacólogos. 
Deve-se estar atento à forma de uso, pois determinadas plantas ou partes dela não devem ser ingeridas. Deve-se ter cuidado com as plantas que são tóxicas! Algumas plantas tóxicas podem até ser utilizadas como medicinais, mas a diferença entre a dose letal e a curativa pode ser bem tênue (Paiva et al., 2007). Por isso, não se deve arriscar sem a supervisão de um especialista. Informações sobre as principais plantas tóxicas podem ser encontradas no Sistema Nacional de Informações Tóxico-Farmacológicas (Sinitox) (http://www.fiocruz.br/sinitox) ou no Centro de Assistência Toxicológica (CEATOX) (http://www.ceatox.org.br).

\section{Efeito tóxico}

Quando pensamos em planta tóxica, associamos logo à ideia de um efeito imediato, ou seja, pronta intoxicação e, em determinados casos, o óbito. Mas existem plantas tóxicas que agem silenciosamente e o seu efeito tóxico é acumulativo. A intoxicação só é percebida muitos anos depois, através do desenvolvimento de tumores e/ou falência de algum órgão. E muitas das vezes nem se associa a presença dessas doenças com a ingestão das plantas (Matos et al., 2011; Paiva et al., 2007).

Nesse sentido, é importantíssimo o diálogo entre os saberes tradicionais e os científicos, pois sabe-se, hoje, que diversas plantas utilizadas tradicionalmente possuem substâncias tóxicas de efeito acumulativo. Assim, mais uma vez, deve-se conhecer bem a planta antes de usá-la.

\section{Interaçôes com outras plantas ou outros medicamentos}

Os fitoterápicos são compostos por cerca de 2.000 a 4.000 substâncias químicas ativas, sem contar as inativas, que, quando ingeridas, podem interferir com outros medicamentos que a pessoa possa estar usando. Assim, deve-se sempre informar ao profissional de saúde as plantas medicinais ou fitoterápicos que estão sendo utilizados, como o alho (Alium sativum), que não deve ser utilizado antes de cirurgias, por favorecer o risco de sangramentos, ou o guaco (Mikania spp.), que não deve ser utilizado juntamente a medicamentos anticoagulantes, como a varfarina, pelo mesmo motivo. Algumas plantas medicinais interferem com diversos medica- 
mentos, como é o caso do Hypericum perforatum L. (Hypericaceae), assim, sua utilização, juntamente a outros medicamentos, como antiretrovirais e anticoncepcionais, deve ser feita muito cuidadosamente.

\section{Consideraçōes finais}

As plantas medicinais e fitoterápicos são um excelente recurso terapêutico, recomendado pela OMS e por políticas públicas nacionais. Assim, sabendo-se utilizá-las, pode-se ter alternativas aos medicamentos convencionais.

O país possui políticas públicas para fitoterápicos, como também um arcabouço legislativo avançado internacionalmente. Com isso, espera-se que as interações entre conhecimentos tradicionais e científicos sejam intensificadas, de modo que novos conhecimentos sejam gerados ou registrados para obtenção de novos fitoterápicos.

\section{Referências}

ALBUQUERQUE U. P. e HANAZAKI, N. "As pesquisas etnodirigidas na descoberta de novos fármacos de interesse médico e farmacêutico: fragilidades e pespectivas". Revista Brasileira de Farmacognosia, v. 16, pp. 678-89, 2006.

et al. "Are ethnopharmacological surveys useful for the Discovery and development of drugs from medicinal plants?" Revista Brasileira de Farmacognosia/Brazilian Journal of Pharmacognosy, v. 24, pp. 110-5, 2014.

BEGOSSI, A. et al. "Estudos de Ecologia Humana e Etnobiologia: uma revisão sobre usos e conservação". In: ROCHA, C. F. D. et al. (orgs.). Biologia da Conservação: essências. São Carlos: RiMa, 2006, pp. 537-62.

BRASIL. Constituição da República Federativa do Brasil. Brasília: Congresso Nacional, 1988.

. Ministério da Saúde. "Portaria 3.916, de 30 de outubro de 1998". Aprova a Política Nacional de Medicamentos. Brasília, 1998. 
- Ministério da Saúde. Conselho Nacional de Saúde. "Resolução 338, de 06 de maio de 2004”. Brasília, 2004.

. Ministério da Saúde. "Portaria 971, de 03 de maio de 2006". Aprova a Politica Nacional de Práticas Integrativas e Complementares (PNPIC) no Sistema Único de Saúde. Brasília, 2006a.

. Ministério da Saúde. Política nacional de práticas integrativas e complementares no SUS: atitude de ampliação de acesso. Brasília, 2006b.

. Presidência da República. "Decreto n. ${ }^{\circ}$ 5.813, de 22 de junho de 2006”. Brasília, 2006c.

Ministério da Saúde. "Portaria GM/MS 3.237, de 24 de dezembro de 2007". Define o elenco de referência de medicamentos e insumos complementares para a assistência farmacêutica na atenção básica em saúde. Brasília, 2007.

. Ministério da Saúde. "Portaria Interministerial 2.960, de 9 de dezembro de 2008". Aprova o Programa Nacional de Plantas Medicinais e Fitoterápicos e cria o Comitê Nacional de Plantas Medicinais e Fitoterápicos. Brasília, 2008.

. Ministério da Saúde. "Relação de plantas medicinais de interesse ao SUS”. Disponível em: http://portal.saude.gov.br/portal/arquivos/ pdf/RENISUS.pdf. Acesso em: 22 jan. 2009.

Ministério da Saúde. "Portaria 886, de 20 de abril 2010". Institui a Farmácia Viva no âmbito do Sistema Único de Saúde (SUS). Brasília, 2010.

- Ministério da Saúde. Agência Nacional de Vigilância Sanitária. "RDC 18, de 3 de abril de 2013". Dispõe sobre as boas práticas de processamento e armazenamento de plantas medicinais, preparação e dispensação de produtos magistrais e oficinais de plantas medicinais e fitoterápicos em farmácias vivas no âmbito do Sistema Único de Saúde (SUS). Brasília, 2013a.

. Ministério da Saúde. Secretaria de Ciência, Tecnologia e Insumos Estratégicos, Departamento de Assistência Farmacêutica e Insumos Estratégicos. Relação Nacional de Medicamentos Essenciais: Rename 2013. Brasília, 2013b.

Ministério da Saúde. Agência Nacional de Vigilância Sanitária. "Instrução Normativa 04, de 18 de junho de 2014". Determina a 
publicação do guia de orientação para registro de Medicamento Fitoterápico e registro e notificação de Produto Tradicional Fitoterápico. Brasília, 2014.

Ministério da Saúde. Secretaria-Executiva. Secretaria de Atenção à Saúde. Glossário temático: práticas integrativas e complementares em saúde. Brasília, 2018. Disponível em: http://portalarquivos2.saude.gov.br/images/pdf/2018/marco/12/glossario-tematico.pdf. Acesso em: 01 jun. 2018.

CORREA JÚNIOR, C. et al. Cultivo de plantas medicinais, condimentares e aromáticas. Paraná: EMATER, 1991.

DI STASI, L. C. Plantas medicinais: arte e ciência - um guia de estudo interdisciplinar. São Paulo: Editora Unesp, 1996.

ELISABETSKY, E. "Etnofarmacologia". Ciência e Cultura, v. 55, n. 3, pp. 35-6, 2003.

FURLAN, M. R. "Aspectos agronômicos em plantas medicinais". In: DI STASI, L.C. (org.). Plantas medicinais: arte e ciência - Um guia de estudo interdisciplinar. São Paulo: Editora Unesp, 1996, pp. 157-68.

KHAFAGI, I. K. e DEWEDAR, A. "The efficiency of random versus ethno-directed research in the evaluation of Sinai medicinal plants for bioactive compounds". Journal of Ethnopharmacology, v. 71, pp. 365-76, 2000.

LORENZI, H. e MATOS, F. J. A. Plantas medicinais no Brasil: nativas e exóticas cultivadas. Nova Odessa: Instituto Plantarum, 2002.

MATOS, F. J. A. et al. Plantas tóxicas: estudos de fitotoxicologia química de plantas brasileiras. São Paulo: Instituto Plantarum de Estudos da Flora, 2011.

MORAN, K. et al. "Biodiversity prospecting: lessons and prospects". Annual Review of Anthropology, v. 30, pp. 505-26, 2001.

NASCIMENTO JÚNIOR, J. M. et al. "Política Nacional de Medicamentos Fitoterápicos". Revista de Administração Hospitalar e Inovação em Saúde, v. 5, n. 4, pp. 42-9, 2010.

OLIVEIRA, F. C. et al. "Avanços nas pesquisas etnobotânicas no Brasil". Acta Botânica Brasilica, v. 23, n. 2, pp. 590-605, 2009.

OMS. "Cuidados Primários de Saúde”. Relatório da Conferência Internacional sobre Cuidados Primários de Saúde. Brasília: Ministério da Saúde, 1979. 
ONU. "Convenção sobre Diversidade Biológica". Rio de janeiro, 2002. Disponível em: http://www.onu-brasil.org.br/doc_cdb.php. Acesso em: 20 fev. 2011.

PAIVA, S. R. et al. "O uso de plantas medicinais pode trazer riscos à saúde humana?”. Interagir: pensando a extensão, n. 11, pp. 121-6, 2007. et al. Plantas medicinais: manual de identificação, propriedades e cultivo. Rio de Janeiro: Populis/UFF/UERJ/FAPERJ, 2009.

PROGRAMA REFLORA/CNPq. Flora do Brasil 2020. Disponível em: http://floradobrasil.jbrj.gov.br/. Acesso em: 20 jun. 2018.

REIS, M. S. e MARIOT, A. "Diversidade natural e aspectos agronômicos de plantas medicinais." In: SIMÕES, C. M. O. et al. (orgs.). Farmacognosia: da planta ao medicamento. Porto Alegre: Ed. UFRGS; Florianópolis: Ed. da UFSC, 1999, pp. 39-60.

SANTOS, C. A. M. et al. Plantas medicinais: Herbarium flora et scientia. São Paulo: Ícone; Curitiba: Scientia et Labor, 1988.

THE ANGIOSPERM PHYLOGENY GROUP. "An update of the Angiosperm Phylogeny Group classification for the orders and families of flowering plants: APG IV". Botanical Journal of the Linnean Society, v. 181, pp. 1-20, 2016.

THE PLANT LIST. A working list of all plant species. Disponível em: http:// www.theplantlist.org. Acesso em: 20 jun. 2018. 
Tabela 1. Relaçăo Nacional de medicamentos fitoterápicos industrializados ofertados no Sistema Único de Saúde (SUS), segundo a Relaçầo Nacional de Medicamentos Essenciais (Brasil, 2013b). A nomenclatura original das espécies foi atualizada através das bases de dados do The Plant List e Flora do Brasil 2020. 0 sistema de classificaçăo adotado foi o APG IV (The Angiosperm Phylogeny Group, 2016).

\begin{tabular}{|c|c|c|c|}
\hline $\begin{array}{l}\text { Nome } \\
\text { popular }\end{array}$ & $\begin{array}{l}\text { Nome } \\
\text { científico }\end{array}$ & $\begin{array}{c}\text { Atualização } \\
\text { nomenclatural }\end{array}$ & Indicação(ões) \\
\hline $\begin{array}{l}\text { Espinheira- } \\
\text {-santa }\end{array}$ & $\begin{array}{l}\text { Maytenus } \\
\text { officinalis }\end{array}$ & $\begin{array}{l}\text { Maytenus ilicifolia } \\
\text { Mart. ex Reissek } \\
\text { (Celastraceae) }\end{array}$ & $\begin{array}{l}\text { Coadjuvante no trata- } \\
\text { mento de gastrite e úlcera } \\
\text { gastroduodenal e sinto- } \\
\text { mas de dispepsia. }\end{array}$ \\
\hline Guaco & $\begin{array}{l}\text { Mikania } \\
\text { glomerata }\end{array}$ & $\begin{array}{l}\text { Mikania glomerata } \\
\text { Spreng. (Astera- } \\
\text { ceae) }\end{array}$ & $\begin{array}{l}\text { Expectorante e broncodi- } \\
\text { latador. }\end{array}$ \\
\hline Alcachofra & $\begin{array}{c}\text { Cynara scoly- } \\
\text { mus }\end{array}$ & $\begin{array}{l}\text { Cynara scolymus L. } \\
\text { (Asteraceae) }\end{array}$ & $\begin{array}{l}\text { Tratamento dos sintomas } \\
\text { de dispepsia funcional } \\
\text { (síndrome do descon- } \\
\text { forto pós-prandial) e de } \\
\text { hipercolesterolemia leve a } \\
\text { moderada. } \\
\text { Apresenta ação colagoga } \\
\text { e colerética. }\end{array}$ \\
\hline Aroeira & $\begin{array}{l}\text { Schinus } \\
\text { terebenthi- } \\
\text { folius }\end{array}$ & $\begin{array}{l}\text { Schinus terebinthifo- } \\
\text { lia Raddi (Anacar- } \\
\text { diaceae) }\end{array}$ & $\begin{array}{l}\text { Apresenta ação cicatri- } \\
\text { zante, anti-inflamatória e } \\
\text { anti-séptica tópica, para } \\
\text { uso ginecológico. }\end{array}$ \\
\hline $\begin{array}{l}\text { Cáscara sa- } \\
\text { grada }\end{array}$ & $\begin{array}{l}\text { Rhamnus } \\
\text { purshiana }\end{array}$ & $\begin{array}{l}\text { Frangula purshia- } \\
\text { na Cooper (Rham- } \\
\text { naceae) }\end{array}$ & $\begin{array}{l}\text { Coadjuvante nos casos de } \\
\text { obstipação eventual. }\end{array}$ \\
\hline
\end{tabular}




\begin{tabular}{|c|c|c|c|}
\hline $\begin{array}{l}\text { Nome } \\
\text { popular }\end{array}$ & $\begin{array}{l}\text { Nome } \\
\text { científico }\end{array}$ & $\begin{array}{c}\text { Atualização } \\
\text { nomenclatural }\end{array}$ & Indicação(ões) \\
\hline $\begin{array}{l}\text { Garra-do- } \\
\text {-diabo }\end{array}$ & $\begin{array}{l}\text { Harpagophy- } \\
\text { tum procum- } \\
\text { bens }\end{array}$ & $\begin{array}{l}\text { Harpagophytum pro- } \\
\text { cumbens (Burch.) } \\
\text { DC. ex Meisn. } \\
\text { (Pedaliaceae) }\end{array}$ & $\begin{array}{l}\text { Tratamento da dor lom- } \\
\text { bar baixa aguda e como } \\
\text { coadjuvante nos casos de } \\
\text { osteoartrite. } \\
\text { Apresenta ação anti-infla- } \\
\text { matória. }\end{array}$ \\
\hline $\begin{array}{c}\text { Isoflavonas de } \\
\text { soja }\end{array}$ & Glycine max & $\begin{array}{l}\text { Glycine max (L.) } \\
\text { Merr. } \\
\text { (Fabaceae) }\end{array}$ & $\begin{array}{l}\text { Climatério (coadjuvante } \\
\text { no alívio dos sintomas). }\end{array}$ \\
\hline Unha-de-gato & $\begin{array}{l}\text { Uncaria } \\
\text { tomentosa }\end{array}$ & $\begin{array}{l}\text { Uncaria tomento- } \\
\text { sa (Willd. ex Roem. } \\
\& \text { Schult.) DC. } \\
\text { (Rubiaceae) }\end{array}$ & $\begin{array}{l}\text { Coadjuvante nos casos } \\
\text { de artrites e osteoartrite. } \\
\text { Apresenta ação anti-infla- } \\
\text { matória e imunomodu- } \\
\text { ladora. }\end{array}$ \\
\hline Hortelã & $\begin{array}{l}\text { Menthax } \\
\text { piperita }\end{array}$ & $\begin{array}{l}\text { Mentha } \times \text { piperi- } \\
\text { ta } \mathrm{L} . \\
(\text { Lamiaceae })\end{array}$ & $\begin{array}{l}\text { Tratamento da síndrome } \\
\text { do cólon irritável. } \\
\text { Apresenta ação antiflatu- } \\
\text { lenta e antiespasmódica. }\end{array}$ \\
\hline Babosa & Aloe vera & $\begin{array}{l}\text { Aloe vera (L.) } \\
\text { Burm.f. (Xanthor- } \\
\text { rhoeaceae) }\end{array}$ & $\begin{array}{l}\text { Tratamento tópico de } \\
\text { queimaduras de } 1 .^{\circ} \text { e } 2 .^{\circ} \\
\text { graus e como coadjuvan- } \\
\text { te nos casos de Psoriasis } \\
\text { vulgaris. }\end{array}$ \\
\hline Plantago & $\begin{array}{l}\text { Plantago } \\
\text { ovata }\end{array}$ & $\begin{array}{l}\text { Plantago ovata } \\
\text { Forssk. (Plantagi- } \\
\text { naceae) }\end{array}$ & $\begin{array}{l}\text { Coadjuvante nos casos de } \\
\text { obstipação habitual. } \\
\text { Tratamento da síndrome } \\
\text { do cólon irritável. }\end{array}$ \\
\hline Salgueiro & Salix alba & $\begin{array}{l}\text { Salix alba L. (Sali- } \\
\text { caceae) }\end{array}$ & $\begin{array}{l}\text { Tratamento de dor lom- } \\
\text { bar baixa aguda. } \\
\text { Apresenta ação anti-infla- } \\
\text { matória. }\end{array}$ \\
\hline
\end{tabular}




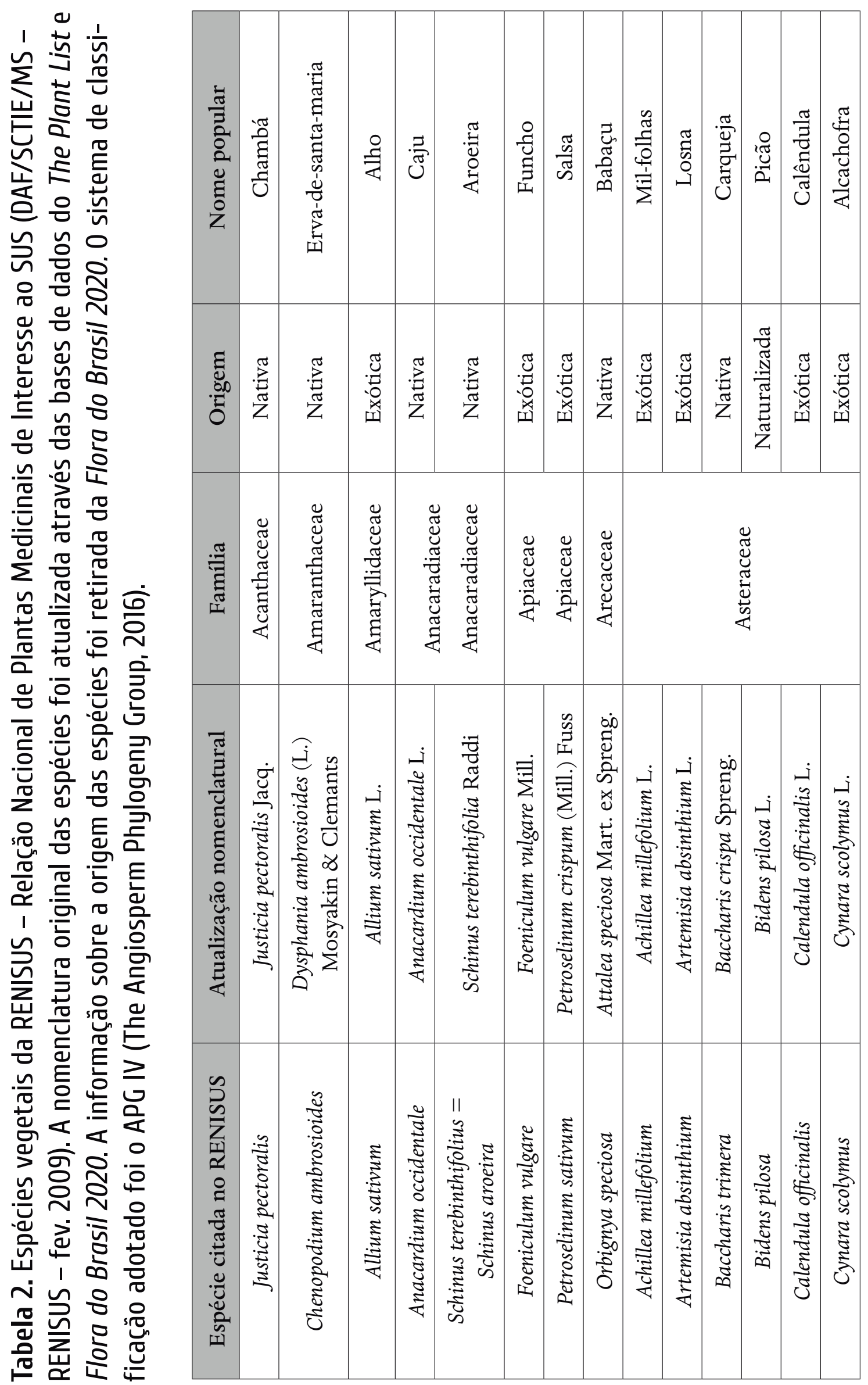




\begin{tabular}{|c|c|c|c|c|c|c|c|c|c|c|c|c|}
\hline 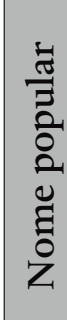 & $\begin{array}{l}\frac{0}{0} \\
\frac{0}{0} \\
0\end{array}$ & 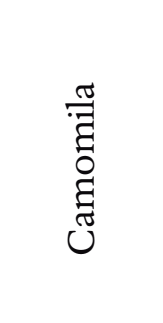 & 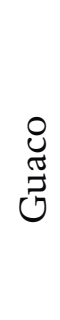 & 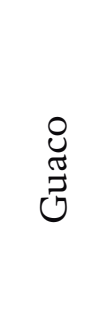 & 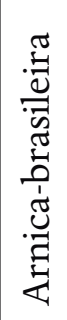 & 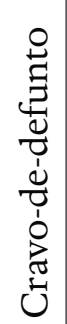 & 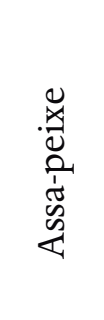 & 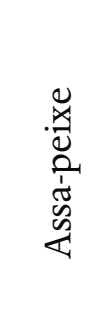 & 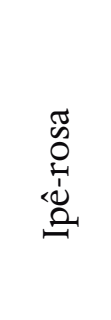 & 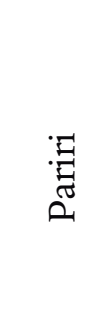 & 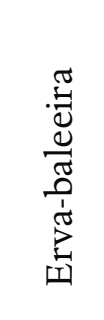 & $\begin{array}{l}\mathbb{x} \\
\widetilde{U} \\
\tilde{\mathbb{Z}} \\
\mathcal{Z}\end{array}$ \\
\hline בే: & 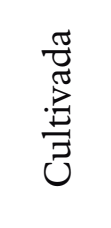 & 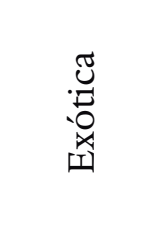 & $\stackrel{\text { 己 }}{\stackrel{\widetilde{D}}{Z}}$ & $\begin{array}{l}\stackrel{\vec{D}}{\vec{\pi}} \\
\text { Z }\end{array}$ & 胥 & 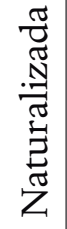 & 胥 & 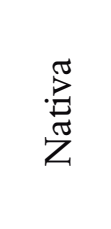 & 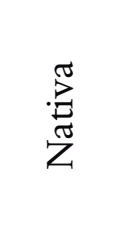 & $\begin{array}{l}\stackrel{\sim}{\mathbb{Z}} \\
\text { Z }\end{array}$ & $\begin{array}{l}\stackrel{\text { D }}{\text { Z }} \\
\text { Z }\end{array}$ & $\begin{array}{l}\stackrel{\tilde{D}}{\tilde{Z}} \\
Z\end{array}$ \\
\hline 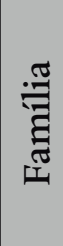 & & & & 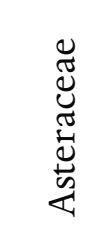 & & & & & & : & 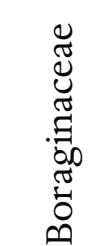 & 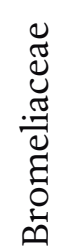 \\
\hline 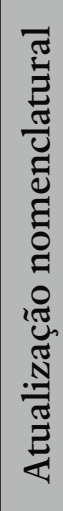 & 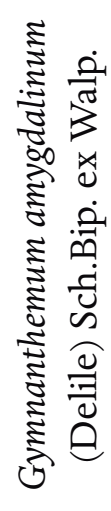 & 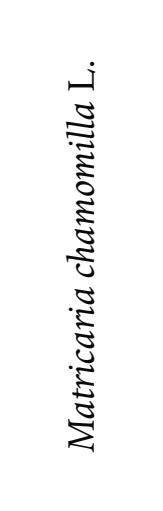 & 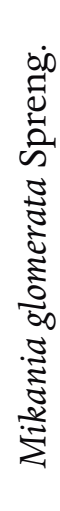 & 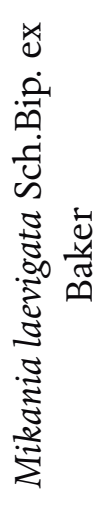 & 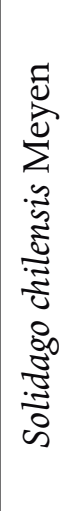 & 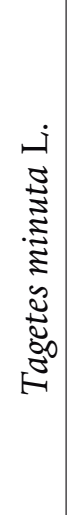 & 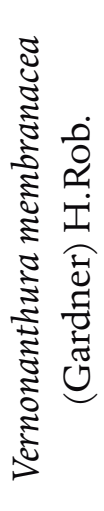 & 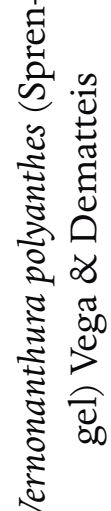 & 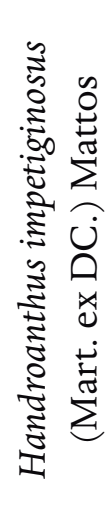 & 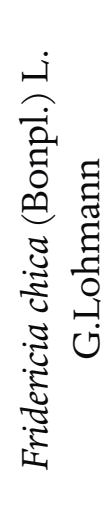 & 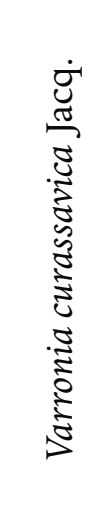 & 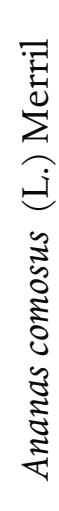 \\
\hline 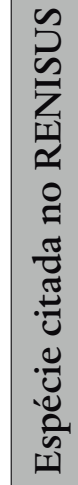 & 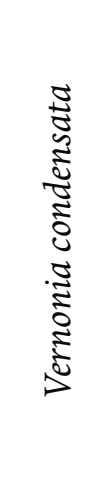 & 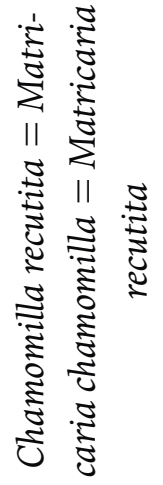 & 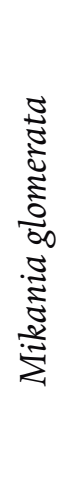 & 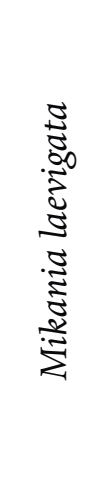 & 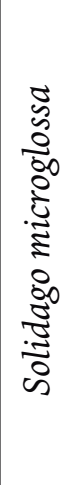 & 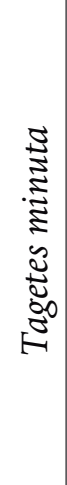 & 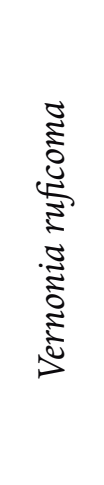 & 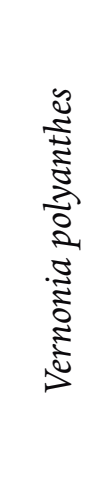 & 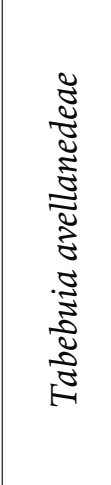 & 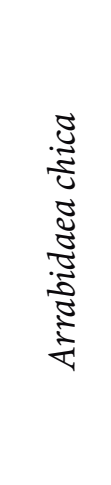 & 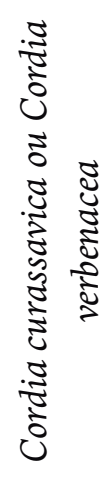 & 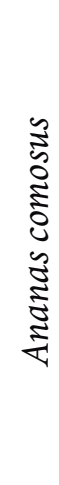 \\
\hline
\end{tabular}




\begin{tabular}{|c|c|c|c|c|c|c|c|c|c|c|c|c|c|c|c|c|}
\hline 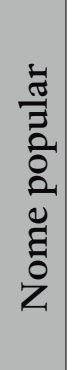 & 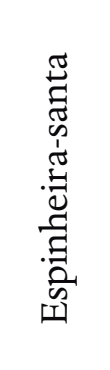 & 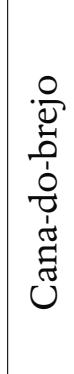 & 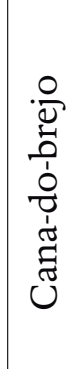 & 券 & 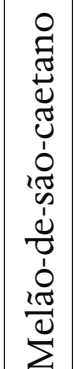 & 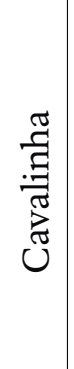 & 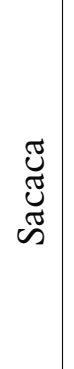 & 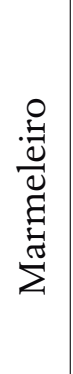 & 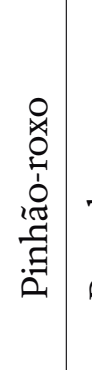 & 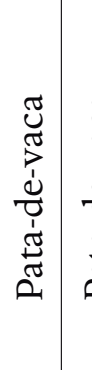 & 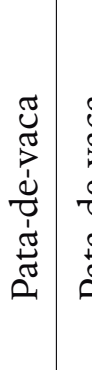 & 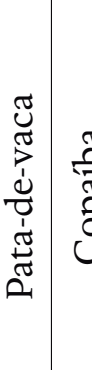 & 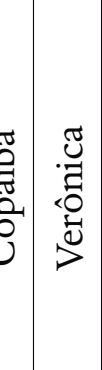 & 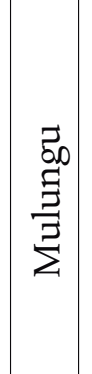 & $\frac{\pi}{2}$ & 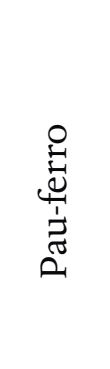 \\
\hline 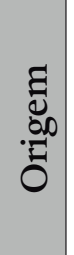 & 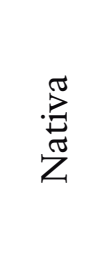 & 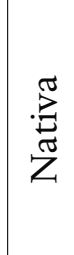 & 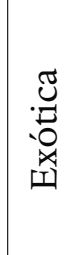 & 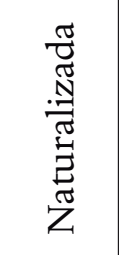 & 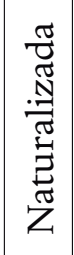 & 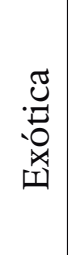 & 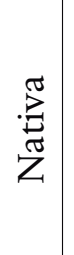 & 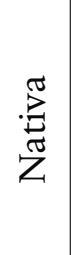 & 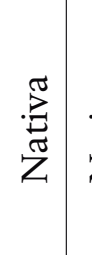 & 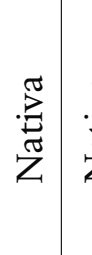 & 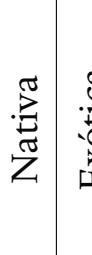 & 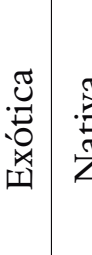 & 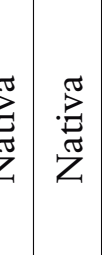 & 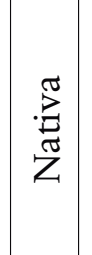 & 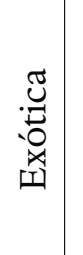 & 胥 \\
\hline 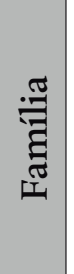 & 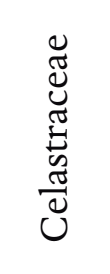 & & 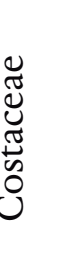 & 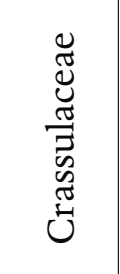 & 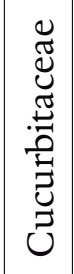 & 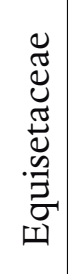 & & 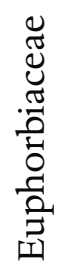 & & & & & 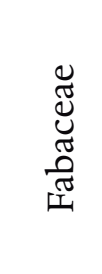 & & & \\
\hline 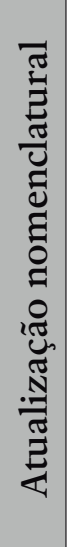 & 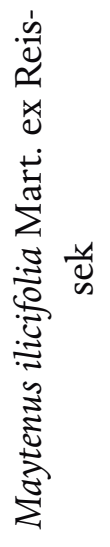 & 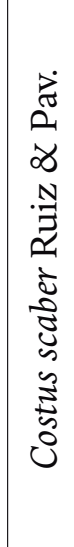 & 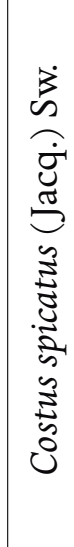 & 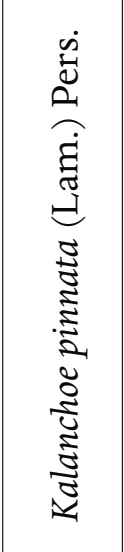 & 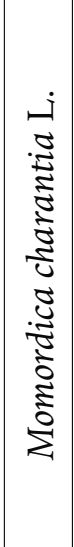 & 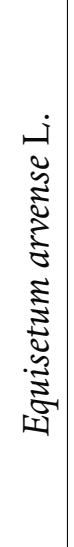 & 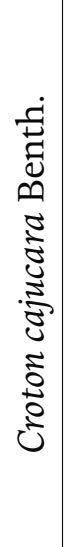 & 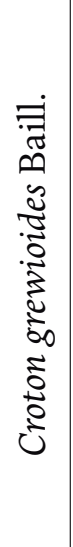 & 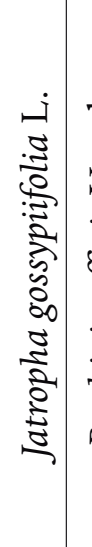 & 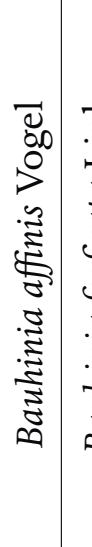 & 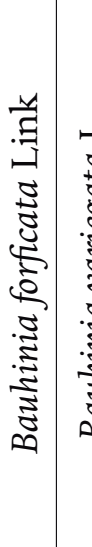 & 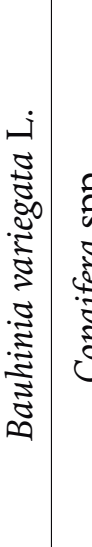 & 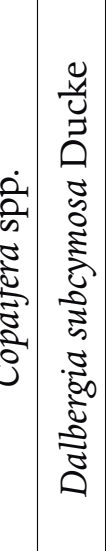 & 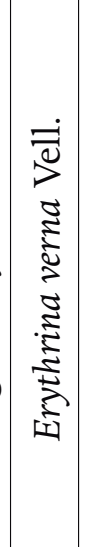 & 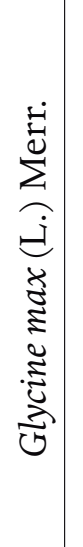 & 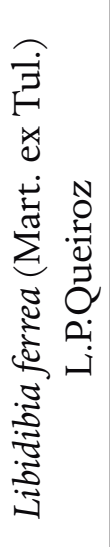 \\
\hline 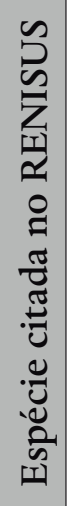 & 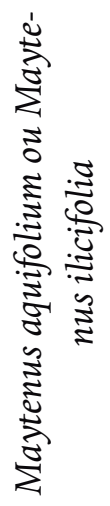 & 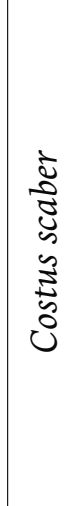 & 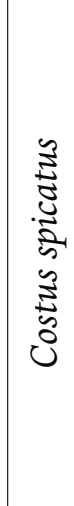 & 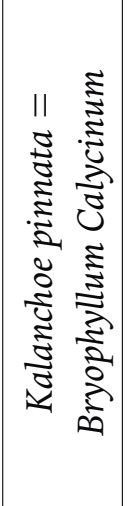 & 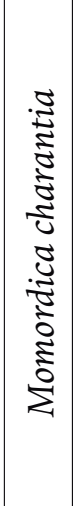 & 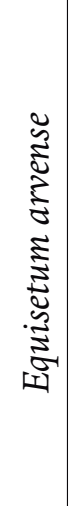 & 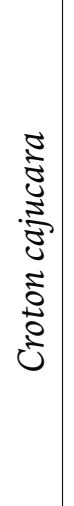 & 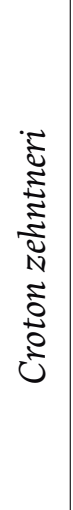 & 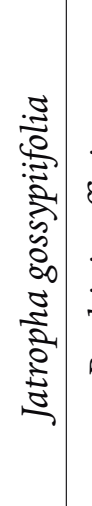 & 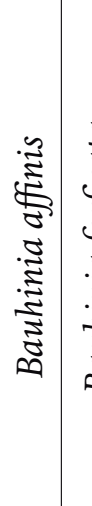 & 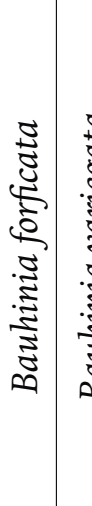 & 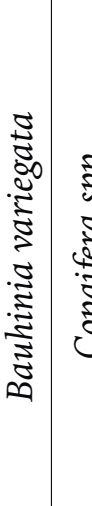 & 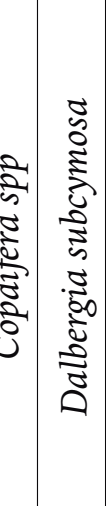 & 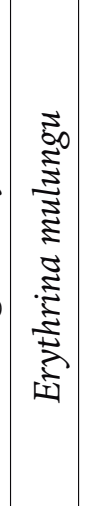 & 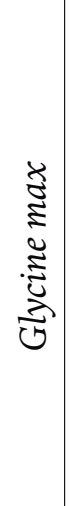 & 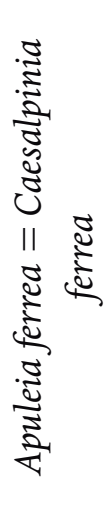 \\
\hline
\end{tabular}




\begin{tabular}{|c|c|c|c|c|c|c|c|c|c|c|c|c|c|c|c|c|c|}
\hline 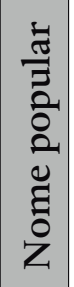 & 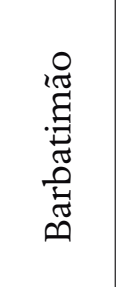 & 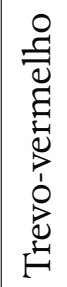 & 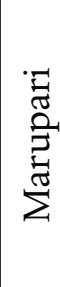 & 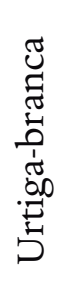 & 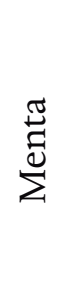 & $\begin{array}{l}\stackrel{0}{\mathbb{d}} \\
\stackrel{0}{\circ} \\
\end{array}$ & 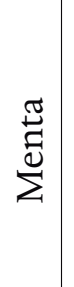 & 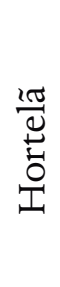 & 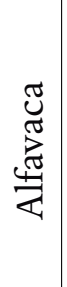 & $\begin{array}{l}0 \\
\frac{7}{0} \\
0 \\
0 \\
0 \\
0 \\
\frac{0}{\pi} \\
\text { T. }\end{array}$ & 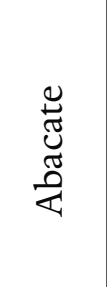 & 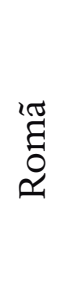 & $\frac{\tilde{s}}{\sum^{\pi}}$ & 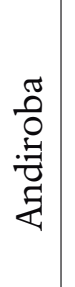 & 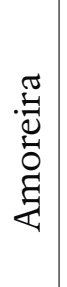 & 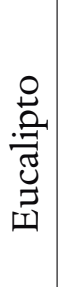 & 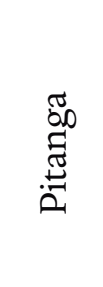 \\
\hline 嫣 & 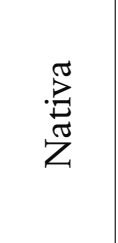 & 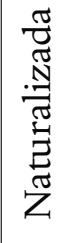 & 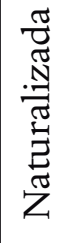 & 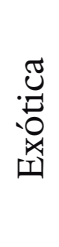 & 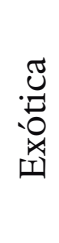 & 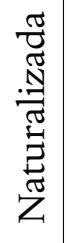 & 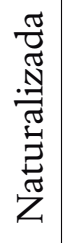 & 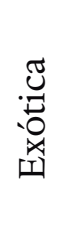 & 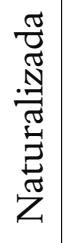 & 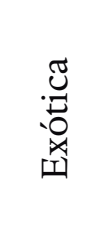 & 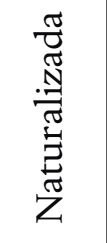 & 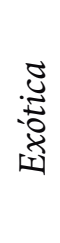 & 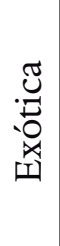 & 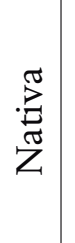 & 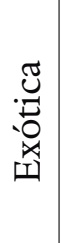 & 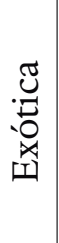 & 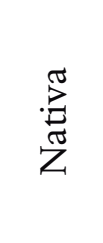 \\
\hline 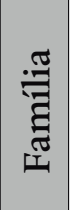 & 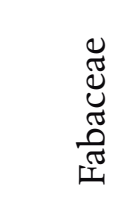 & & 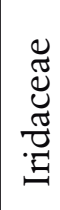 & & & & 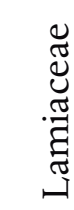 & & & & 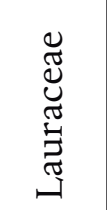 & 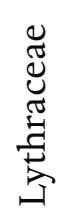 & 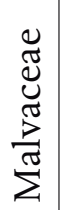 & 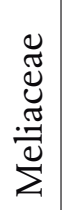 & 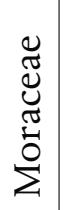 & & 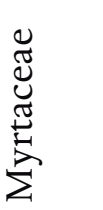 \\
\hline 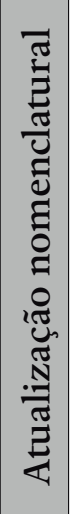 & 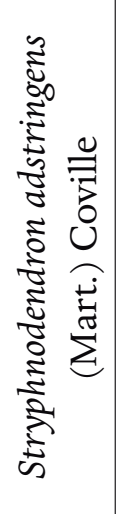 & 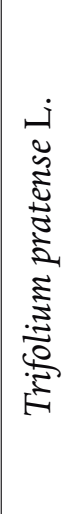 & 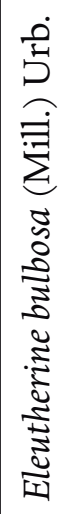 & 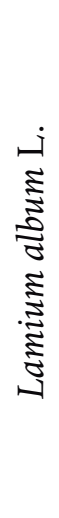 & 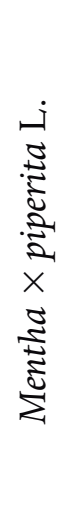 & 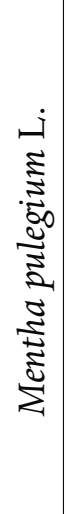 & 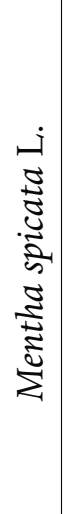 & 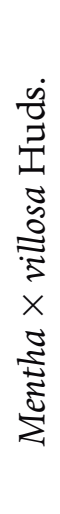 & 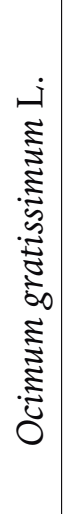 & 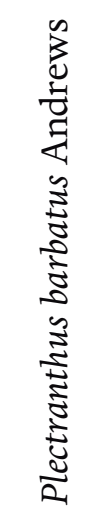 & 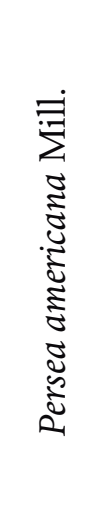 & 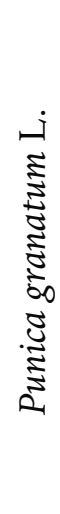 & 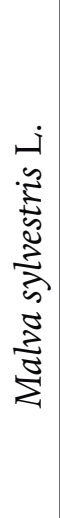 & 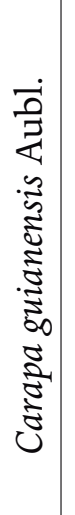 & 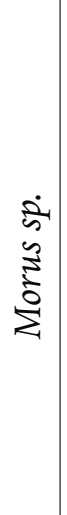 & 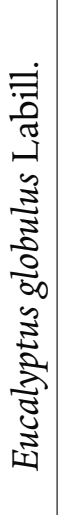 & 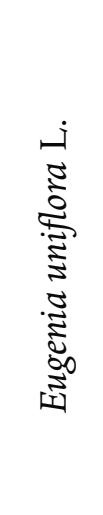 \\
\hline 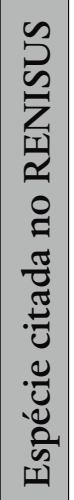 & 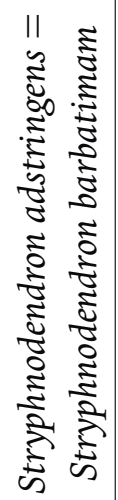 & 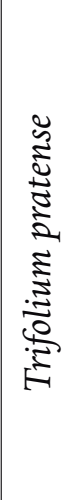 & 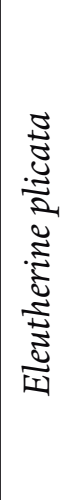 & 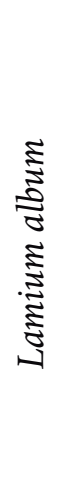 & 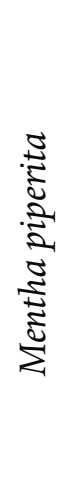 & 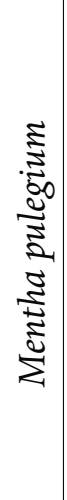 & 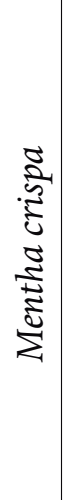 & 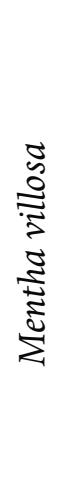 & 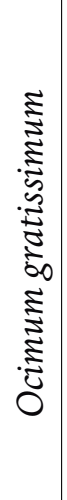 & 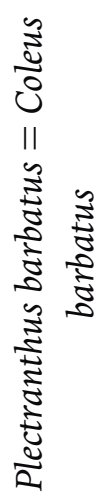 & 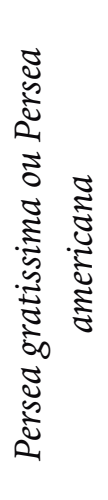 & 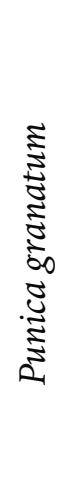 & 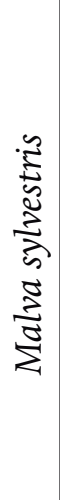 & 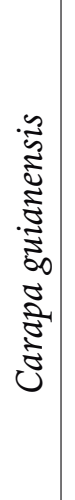 & 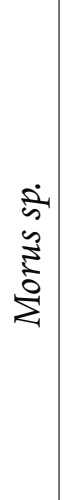 & 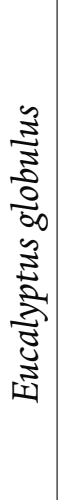 & 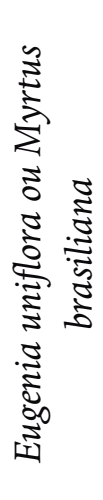 \\
\hline
\end{tabular}




\begin{tabular}{|c|c|c|c|c|c|c|c|c|c|c|c|c|c|c|c|c|}
\hline 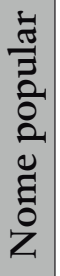 & 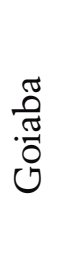 & 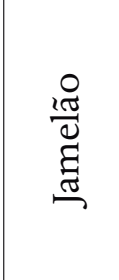 & \begin{tabular}{l}
$: \frac{\pi}{\vec{Z}}$ \\
$\tilde{\pi}$ \\
\multirow{\pi}{*}{} \\
$\sum$
\end{tabular} & $\begin{array}{l}: \frac{\pi}{Z} \\
\stackrel{\tilde{U}}{\pi} \\
\stackrel{\pi}{\pi} \\
\sum\end{array}$ & 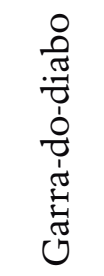 & 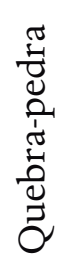 & 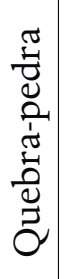 & 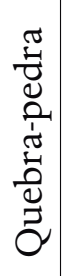 & 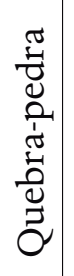 & 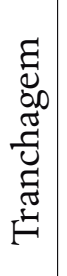 & 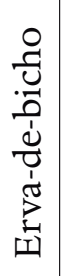 & 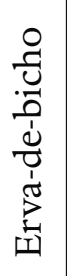 & 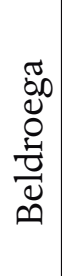 & 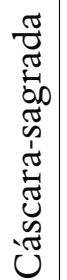 & 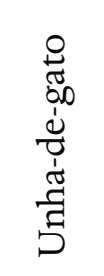 & 焉 \\
\hline 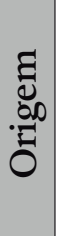 & 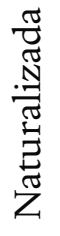 & 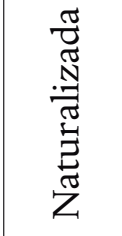 & 疍 & $\begin{array}{l}\stackrel{\pi}{\widetilde{\pi}} \\
\text { Z }\end{array}$ & 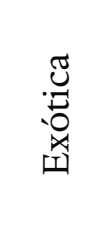 & 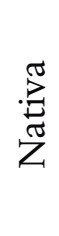 & $\begin{array}{l}\stackrel{\widetilde{\pi}}{\vec{\pi}} \\
\text { Z }\end{array}$ & 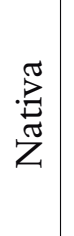 & $\begin{array}{l}\stackrel{\Xi}{\tilde{\pi}} \\
Z^{\pi}\end{array}$ & 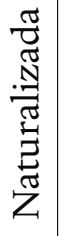 & $\begin{array}{l}\stackrel{\pi}{\tilde{\pi}} \\
Z\end{array}$ & 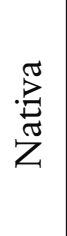 & 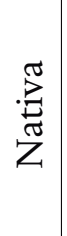 & 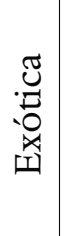 & $\begin{array}{l}\stackrel{\pi}{\tilde{Z}} \\
\text { Z }\end{array}$ & 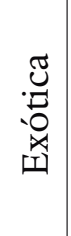 \\
\hline 丞 & & 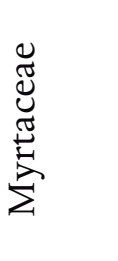 & & 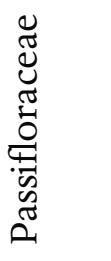 & 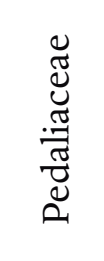 & & 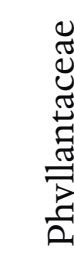 & & & 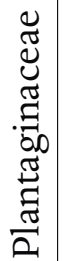 & 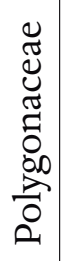 & 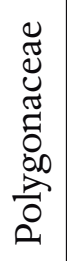 & 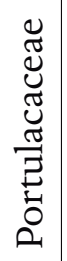 & 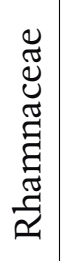 & 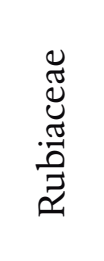 & 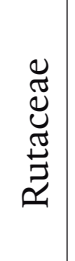 \\
\hline 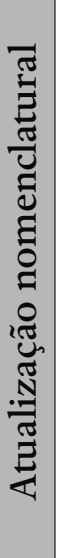 & 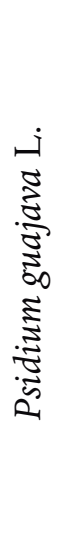 & 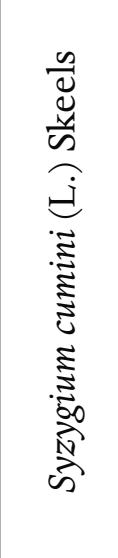 & 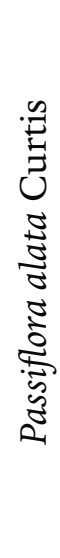 & 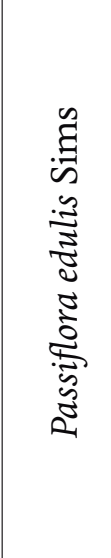 & 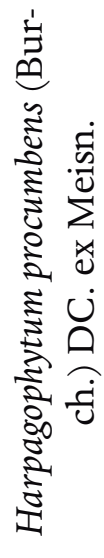 & 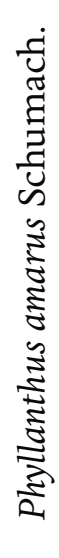 & 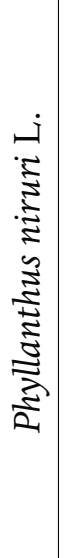 & 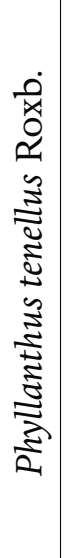 & 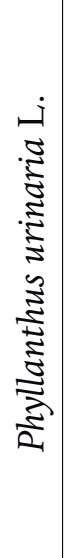 & 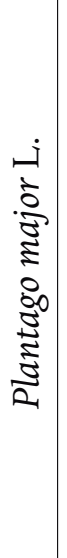 & 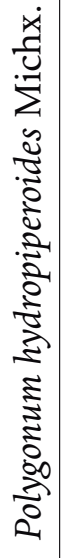 & 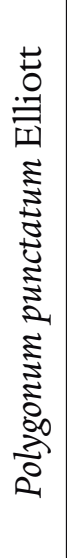 & 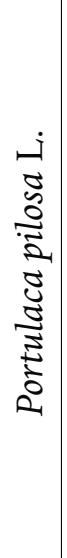 & 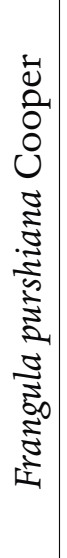 & 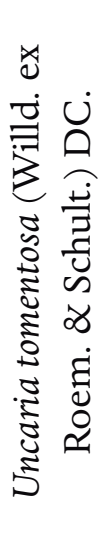 & 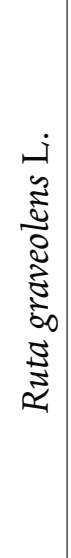 \\
\hline 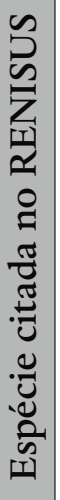 & 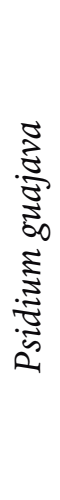 & 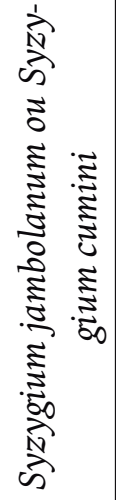 & 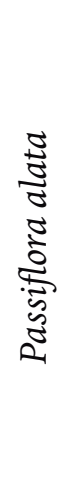 & 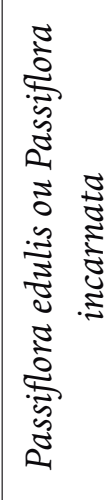 & 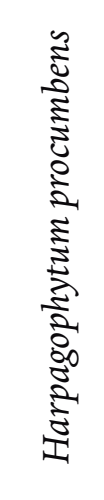 & 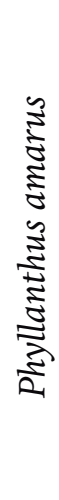 & 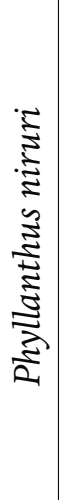 & 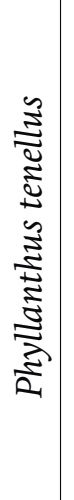 & 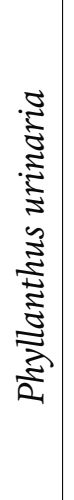 & 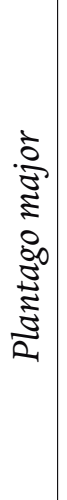 & 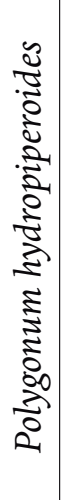 & 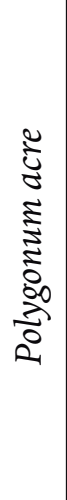 & 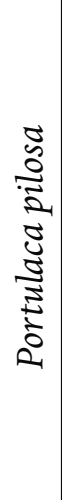 & 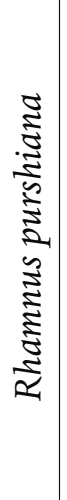 & 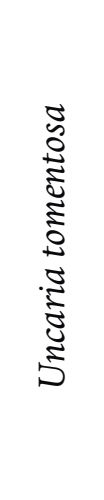 & 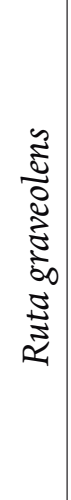 \\
\hline
\end{tabular}




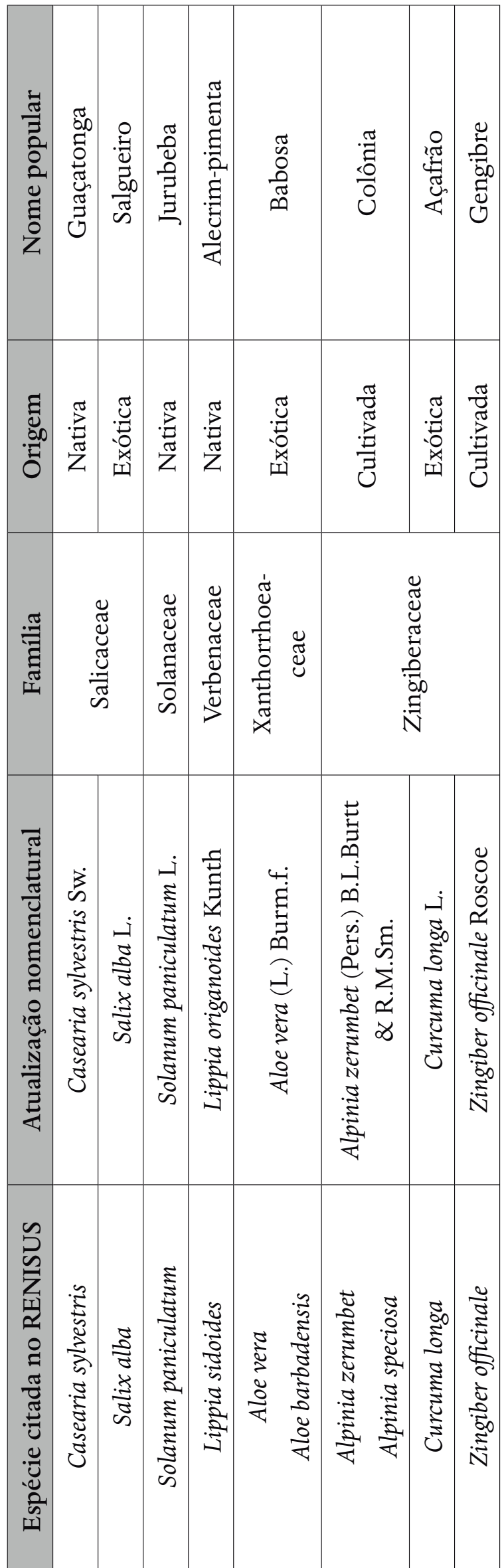




\title{
CAPITULO V
}

\section{Pesquisas etnobotânicas em unidades de conservaçăo no estado do Rio de Janeiro, Brasil}

\author{
Viviane Stern da Fonseca Kruel \\ Juan Gomes Bastos \\ Cyl Farney Catarino de Sá
}

Ao longo da história das civilizações, as diferentes sociedades humanas têm buscado na natureza os recursos para a sua existência, o que tem resultado em maiores oportunidades de sobrevivência, sobretudo a partir da seleção de plantas para as mais diversas finalidades (alimentação, medicamentos, construção de moradias e embarcações etc). Da interação entre populações humanas e o uso diferenciado dos recursos vegetais, emerge a importância da disciplina etnobotânica em meio a um cenário economicamente globalizado e com tendência à perda da diversidade biológica e cultural em diversas escalas.

A etnobotânica é uma disciplina científica que estuda e interpreta a história das plantas nas sociedades antigas e atuais. ${ }^{1}$ Apresenta caráter interdisciplinar, demonstrado na diversidade de tópicos, podendo englobar tanto os fatores culturais, sociais, políticos e econômicos quanto os biológicos e ecológicos. ${ }^{2}$ Essa disciplina tem auxiliado na compreensão da interação das populações humanas com as áreas geográficas que ainda apresentam vegetação e flora nativas, assim como no fortalecimento de informações para o planejamento participativo e gestão de unidades de conservação, na troca de experiências práticas de compartilhamento nos ambientes naturais e, por conseguinte, pode ainda responder a mudanças nestes ecossistemas. ${ }^{3}$

\footnotetext{
1 Alexiades e Sheldon, 1996.

Alcorn, 1995; Cunningham, 2000; Albuquerque, 2005.

3 Berkes et al., 1995; Hanazaki, 2002.
} 
As Unidades de Conservação (UCs) - espaços criados para a conservação da biodiversidade e de processos ecológicos, no Brasil - são regulamentadas pela lei que criou o Sistema Nacional de Unidades de Conservação - SNUC, ${ }^{4}$ que "estabelece critérios e normas para a criação, implantação e gestão das unidades de conservação" (Brasil, 2000). Através dessa lei, as UCs existentes, até então, foram distribuídas em doze categorias, sendo cinco delas de proteção integral (Parque Nacional, Reserva Biológica, Estação Ecológica, Monumento Natural e Refúgio de Vida Silvestre) e sete de uso sustentável (Floresta Nacional, Área de Proteção Ambiental, Área de Relevante Interesse Ecológico, Reserva Extrativista, Reserva de Fauna, Reserva de Desenvolvimento Sustentável, Reserva Particular do Patrimônio Natural). Apesar dessa organização, Dourojeanni e Pádua (2013) tecem algumas interessantes críticas e reflexões sobre o excesso de categorias de UCs no Brasil, além do fato de que poderiam ser reduzidas pela metade, dado o nível de confusão gerado por diferenças muito sutis entre categorias.

A “Lei do SNUC", segundo Santilli (2014), além de definir as doze categorias de UCs, ressalta, dentre os principais objetivos: "proteger os recursos naturais à subsistência de populações tradicionais, respeitando e valorizando seu conhecimento e sua cultura e promovendo-as social e economicamente". A autora destaca ainda que "o conjunto de políticas públicas reforça a necessidade de uma interpretação sistêmica e integrada dos instrumentos legais de proteção ao meio ambiente e cultura”.

As primeiras UCs criadas no Brasil foram os Parques Nacionais, cujos fundamentos para a criação, de acordo com Barros (1952), seriam "a topografia, a geologia, os ambientes floro-faunianos, os acidentes criados pela natureza no seu longo processo evolutivo". Rylands $\&$ Brandon (2005), ao analisarem as UCs brasileiras criadas até aquele momento, relatam que, além dos critérios biogeográficos aplicados entre 1980-90, outros três critérios mais recentes: os corredores de biodiversidade, os workshops para a definição de áreas prioritárias e o programa de áreas protegidas para a Amazônia (ARPA). A primeira UC brasileira (um parque nacional) foi criada no estado do Rio de Janeiro, em 1937, a partir da Estação Biológica do Jardim Botânico do Rio de Janeiro - o Parque Nacional do Itatiaia. Esse parque, situado numa das montanhas mais altas do país, está entre

${ }^{4}$ Lei no 9.985 de 18 de julho de 2000. 
os principais parques nacionais do Brasil ${ }^{5}$ e é detentor de uma significativa riqueza de espécies de Angiospermas, estimada atualmente em 1.206 táxons e com muitas espécies endêmicas. ${ }^{6}$ Ele continua a ser ativamente estudado e, de acordo com Bittencourt e Paula (2012), guardadas as limitações metodológicas, foi dentre os parques nacionais brasileiros o que registrou o maior número de publicações científicas até 2012. Merecem também destaque as mais de 9.000 amostras de plantas depositadas no Herbário do Jardim Botânico do Rio de Janeiro (RB) e que espelham também a atividade científica em botânica nesse parque nacional.

O exemplo acima demonstra que a riqueza de espécies desta e de muitas outras UCs também necessita ser documentada e relacionada à história de uso da flora e da vegetação nativa por comunidades tradicionais que habitam o seu entorno e que ainda detém o conhecimento sobre espécies, usos e suas áreas de ocorrência. Dessa forma, o presente estudo visou traçar um panorama das pesquisas etnobotânicas realizadas nas UCs e seus entornos situadas no estado do Rio de Janeiro, a partir de consultas à artigos e bases de dados de teses e dissertações nos portais: CAPES, Domínio Público, Scielo e Web of Science. Foram considerados os estudos com ênfase em indicações de plantas úteis relacionadas à vegetação das UCs ou em suas proximidades, entretanto os estudos de mercado, feiras livres, comercialização de plantas não foram aqui analisados. De maneira complementar, foi consultado o Cadastro Nacional de Unidades de Conservação - Ministério do Meio Ambiente (MMA) ${ }^{7}$ e as Unidades de Conservação do Instituto Estadual do Ambiente (INEA). ${ }^{8}$

\section{As unidades de conservaçăo fluminenses}

O papel estratégico no estabelecimento e manejo de áreas protegidas e de UCs vem se tornando cada vez mais evidente e urgente no Brasil, em função do crescimento e expansão da população sobre áreas que não deveriam ser ocupadas como estão hoje às margens de rios e lagoas, estu-

\footnotetext{
ICMBio, 2018.

Baumgratz et al., 2014.

MMA, 2018.

INEA, 2018a.
} 
ários, encostas íngremes e áreas de restingas. Invariavelmente, as tragédias ocorridas no passado recente do país (região serrana fluminense, em 2011, inundações no norte do país e escassez de água para abastecimento no sudeste) têm sido atribuídas unicamente à natureza, o que de certa forma minimiza o papel das ações humanas.

O "Cadastro Nacional de Unidades de Conservação"9 contém 684 UCs de Proteção Integral, sendo 367 estaduais (159.190ha), e 1.462 UCs de Uso Sustentável (538 estaduais em 607.626ha). De acordo com esse cadastro, só no estado do Rio de Janeiro foram contabilizadas 295 UCs (112 estaduais, 84 federais e 99 municipais), sendo 79 de proteção integral (tabela 1), com destaque para os parques naturais municipais $(48,1 \%)$ e os parques estaduais (13,9\%). Dentre as 216 UCs de Uso Sustentável fluminense (tabela 2), destacam-se as Reservas Particulares do Patrimônio Natural, estaduais e federais (68,5\%), e as Áreas de Proteção Ambiental - APAs (28,7\%).

Tabela 1. As Unidades de Conservaçăo de Proteçầo Integral no estado do Rio de Janeiro

\begin{tabular}{|l|c|c|c|c|}
\hline Categorias & Federal & Estadual & Municipal & Total \\
\hline Estação Ecológica & 2 & 1 & 0 & 3 \\
\hline Reserva Biológica & 3 & 3 & 1 & 7 \\
\hline Parque & 5 & 11 & 38 & 54 \\
\hline Monumento Natural & 1 & 0 & 8 & 9 \\
\hline Refúgio da Vida Silvestre & 0 & 0 & 6 & 6 \\
\hline Total & 11 & 15 & 53 & 79 \\
\hline
\end{tabular}

Fonte: MMA 2018 - Cadastro Nacional de Unidades de Conservaçăo.

As categorias de UC de Proteção Integral são responsáveis por cerca de $46,7 \%$ do total da superfície de áreas protegidas no Brasil, principalmente pelos parques que representam $61,4 \%$ desse total. ${ }^{10}$ No estado do Rio de Janeiro (tabela 1), não é muito diferente. Os parques representam

\footnotetext{
${ }^{9}$ MMA, 2018.

${ }^{10} \mathrm{MMA}, 2018$.
} 
68,3\% das UCs de Proteção Integral e os cinco parques nacionais, situados no estado, detêm $170.806,98$ ha de áreas protegidas, enquanto outros 184.226ha são protegidos em onze parques estaduais (41\% das áreas protegidas estaduais). As categorias de proteção integral são aquelas onde a proteção da biodiversidade se dá de forma mais efetiva devido as limitações de uso descritas na Lei do SNUC.

Tabela 2. As Unidades de Conservaçăo de Uso Sustentável no estado do Rio de Janeiro

\begin{tabular}{|l|c|c|c|c|}
\hline Categorias & Federal & Estadual & Municipal & Total \\
\hline $\begin{array}{l}\text { Área de Proteção Ambiental } \\
\text { (APA) }\end{array}$ & 5 & 13 & 44 & 62 \\
\hline $\begin{array}{l}\text { Área de Relevante Interesse } \\
\text { Ecológico (ARIE) }\end{array}$ & 1 & 0 & 2 & 3 \\
\hline Floresta Nacional (FLONA) & 1 & 0 & 0 & 1 \\
\hline Reserva Extrativista (RESEX) & 1 & 0 & 0 & 1 \\
\hline Reserva de Fauna & 0 & 0 & 0 & 0 \\
\hline $\begin{array}{l}\text { Reserva de Desenvolvimento } \\
\text { Sustentável (RDS) }\end{array}$ & 0 & 1 & 0 & 1 \\
\hline $\begin{array}{l}\text { Reserva Particular do Patri- } \\
\text { mônio Natural (RPPN) }\end{array}$ & 65 & 83 & 0 & 148 \\
\hline Total & 73 & 97 & 46 & 216 \\
\hline
\end{tabular}

Fonte: MMA 2018 - Cadastro Nacional de Unidades de Conservaçăo.

Dentre as UCs de Uso Sustentável, as RPPNs merecem um destaque especial em termos de análise, já que, de acordo com o SNUC, as RPPNs têm como objetivo a conservação da diversidade biológica, sendo somente admitidas a pesquisa científica e a visitação com objetivos turísticos, recreativos e educacionais. Nesse aspecto, Dourejanni e Pádua (2013), no texto Para melhor desmantelar o paraiso, esclarecem que na verdade essa categoria de UC é de fato e de direito uma UC de Proteção Integral. Assim sendo, o Estado de Santa Catarina, através da Lei n. 11.986 de 12 de novembro de 
2001, já havia enquadrado as RPPNs como UC de Proteção Integral. Atualmente, existem 859 RPPNs cadastradas no Brasil (MMA, 2018). Embora em escalas reduzidas, essas áreas representam 561.900 ha de áreas protegidas, ou seja, menos de $1 \%$ do total de UCs de Uso Sustentável cadastradas.

O "sucesso" inicial da RPPN pode ser atribuído ao fato de ela poder ser criada voluntariamente pelo proprietário das terras, através da submissão de reconhecimento por ato do poder público. Entretanto, Dourejanni e Pádua (2013), baseados em dados do Ibama entre 1990 e 2002, indicaram, no texto Vitimando as reservas particulares, que 440.000 ha de RPPNs já haviam sido criadas. Segundo os autores, esse número recrudesceu desde então devido ao excesso de burocracia no Decreto n. ${ }^{\circ} 4.340$ de 2002, à necessidade de apresentar um plano de manejo e, de acordo com a Instrução Normativa n. 24 de 2004, a um roteiro metodológico exaustivo e extremamente técnico e bastante oneroso para quem decida criar uma RPPN.

As RPPNs vêm sendo uma das categorias de UCs mais peculiares no ordenamento jurídico brasileiro, devido às suas características de domínio e gestão privada da unidade e a participação direta do particular na criação da UC, dando efetividade ao princípio da participação da sociedade na tutela do meio ambiente. No Estado do Rio de Janeiro, existem 148 RPPNs, sendo 83 de âmbito estadual e reconhecidas pelo INEA, e somam 7.154,01ha. ${ }^{11}$ Os municípios de Nova Friburgo, Silva Jardim e Varre-Sai possuem a maior representatividade em relação ao número de RPPNs estaduais por município (figura 1). No âmbito federal, há 65 RPPNs, totalizando 5.925,93ha de área, ${ }^{12}$ sendo os municípios de Silva Jardim, Nova Friburgo e Varre-sai aqueles com maior número de RPPNs por município (figura 1). Até o momento, a maior RPPN no estado do RJ é a Fazenda Caruara, de âmbito estadual (INEA/RJ/PRES n. 357 de 19 de julho de 2012), localizada em São João da Barra (3.844,73ha), seguida por: Fazenda Cachoeirinha - âmbito federal, em Mangaratiba (650ha); Santo Antônio - âmbito estadual, em Resende (538,59ha); Fazenda Santa Izabel - âmbito federal, em Mangaratiba (525ha); Três Morros - âmbito federal, em Casimiro de Abreu (508,78ha). No município de Silva Jardim, encontram-se grandes áreas de RPPN, de âmbito federal, como: a Fazenda Bom Retiro (472ha), Floresta Alta (380,9ha) e União (343,1ha). ${ }^{13}$

\footnotetext{
${ }^{11}$ INEA, 2018b.

${ }^{12}$ MMA - Cadastro Nacional de Unidades de Conservação, 2018.

${ }^{13}$ MMA - Cadastro Nacional de Unidades de Conservação, 2018.
} 
Figura 1. 0s municípios do estado do Rio de Janeiro com até cinco RPPNs reconhecidas pelo ICMBio e INEA

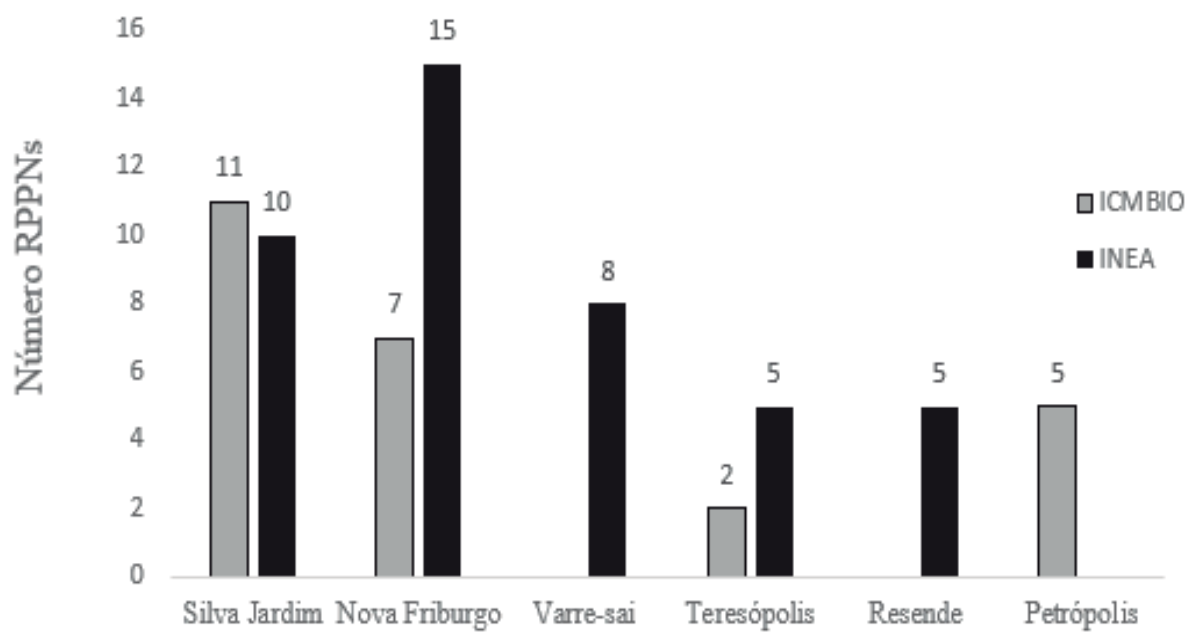

Municípios

Fonte: MMA, 2018 e INEA, 2018.

As APAs estaduais e federais (tabela 2) constituem a segunda categoria de UC de Uso Sustentável mais abundante no estado do Rio de Janeiro. Essas APAs têm uma abrangência diversificada em relação aos municípios e tipos de ambientes (costeiros, como as restingas, quanto para o bioma mata atlântica strictu sensu). Dentre todas as categorias de UCs, as APAs são as de pior reputação, ${ }^{14}$ já que muitas delas não cumprem seu papel para o qual foi criado, muito pelo fato de terem sido criadas sobre terras privadas, ou pretensamente privadas, e que estão a todo tempo ao sabor de pressões políticas e de zoneamentos viciados e de planos de manejo fantasiosos. Nesse aspecto, as APAs estaduais da Região dos Lagos (Maricá, Pau-Brasil, Serra da Sapiatiba e Massambaba) são exemplos claros de áreas que servem muito mais à especulação imobiliária do que à conservação da biodiversidade.

${ }^{14}$ Dourejanni e Pádua, 2013. 


\section{Panorama das pesquisas etnobotânicas}

Nesta análise, consideramos 41 estudos etnobotânicos realizados em UCs e em suas proximidades (tabelas 3 e 4). Desse total, $78 \%$ foram referentes a estudos publicados em periódicos e livros e $22 \%$ a dissertações e teses não publicadas (figura 3). Nas UCs de Proteção Integral encontramos 47\% dos trabalhos realizados em parques estaduais e proximidades (figura 3), seguido pelos parques nacionais (23,5\%) e reservas biológicas (17,6\%). Para as UCs de Uso Sustentável, nove estudos foram relacionados, ${ }^{15}$ sendo seis destes em Área de Proteção Ambiental (tabelas 3 e 4).

A maior parte dos estudos foi realizada em áreas de Floresta Atlântica s.l. (principalmente Floresta Ombrófila Densa Montana e Submontana), seguidos por áreas de restinga, embora existam outras formações associadas, como os campos de altitude, que estão exclusivamente em UCS de Proteção Integral.

Dentre os grupos humanos, residentes no entorno das UCs, relacionados nos artigos desta análise, identificamos principalmente: os sitiantes e comunidades rurais (56\%), os pescadores artesanais e caiçaras $(26,8 \%)$, e as comunidades quilombolas $(4,8 \%)$. Vale destacar que $17 \%$ dos artigos não indicaram os grupos humanos abordados (tabelas 3 e 4). Ressalta-se ainda que o esforço amostral, bem como o enfoque e o número de espécies relacionadas como úteis foram diferentes entre os trabalhos, tendo predominado a categoria de uso medicinal, com $30 \%$ das publicações (tabelas 3 e 4).

Em relação à riqueza de espécies identificadas nos trabalhos, salienta-se que treze deles indicaram mais de cem espécies como úteis para as proximidades das UCs de Proteção Integral (tabela 3), enquanto que, para as UCs de Uso Sustentável (tabela 4), a riqueza de espécies só ultrapassou oitenta citadas como úteis, quando o trabalho também se relacionava com UCs de Proteção Integral (ver nas tabelas 3 e 4).

15 Figueiredo et al., 1997; Fonseca-Kruel e Peixoto, 2004; Borges e Peixoto, 2009; Patzlaff et al., 2011; Boscolo e Fernandes, 2014; Baldini, 2015; Quintero et al., 2015; Mourão et al., 2017; Valverde et al., 2018. 
Figura 2. Análise das UCs de Proteçăo Integral e de Uso Sustentável em relaçăo ao desenvolvimento de pesquisas etnobotânicas no estado do Rio de Janeiro

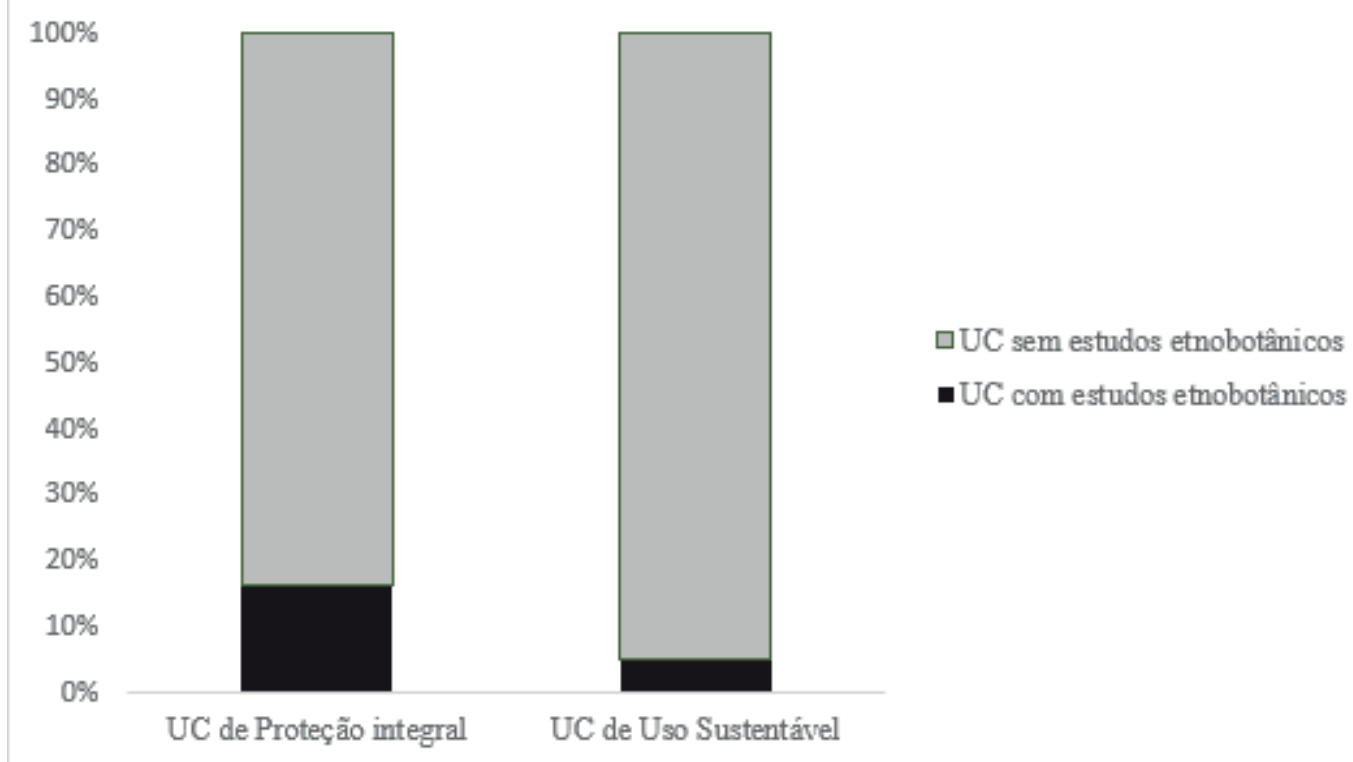

Figura 3. Análise das UCs em relaçầo à presença de dissertaçồes/teses de pós-graduaçăo ou artigos publicados

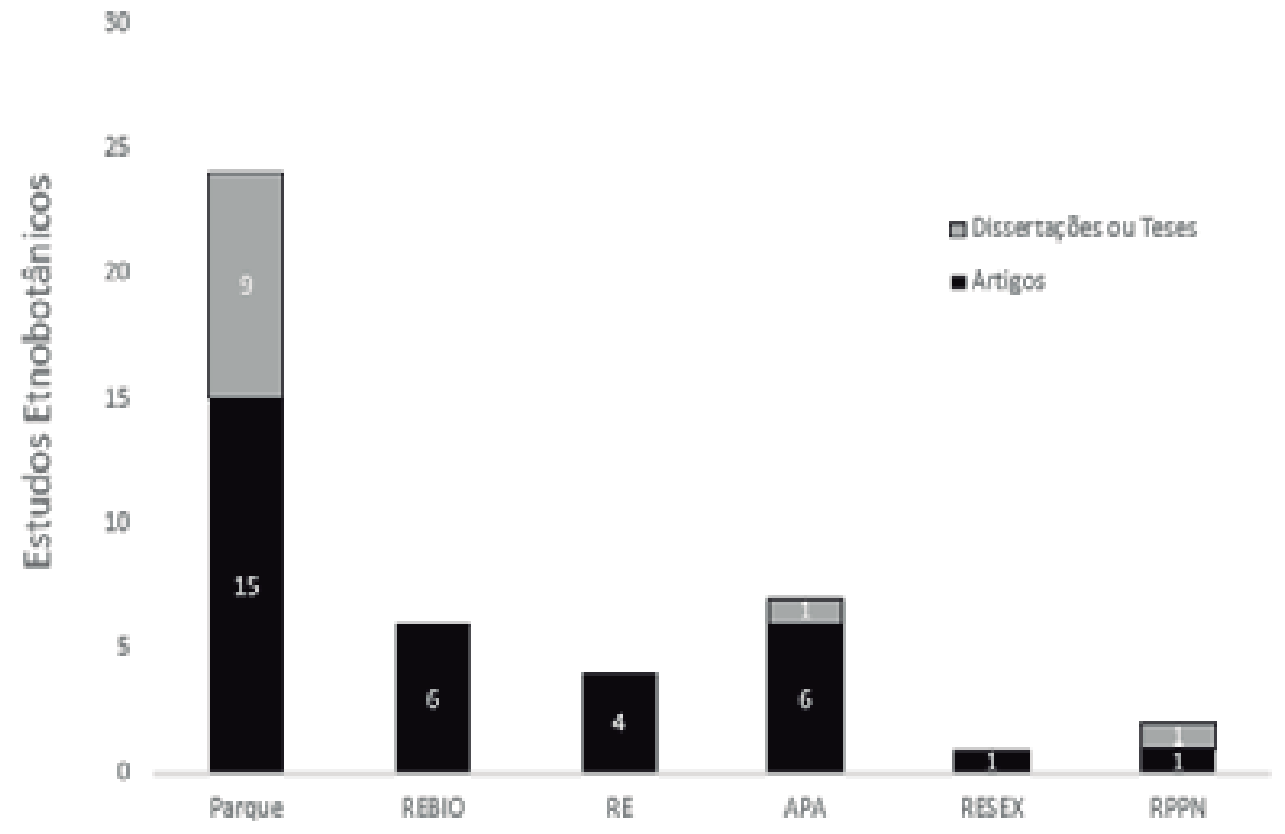




\section{Áreas prioritárias para pesquisas etnobotânicas}

A partir das análises das UCs situadas no estado do Rio de Janeiro (tabelas 1 e 2) e dos trabalhos ali desenvolvidos, na linha de etnobotânica (tabela 3 e 4; figura 3), verificamos que existe um potencial para pesquisas nas UCs de Uso Sustentável (tabela 4; figura 2 e 3). Isto se dá pelo fato de que $73,2 \%$ das UCs fluminenses estão na categoria de uso sustentável, e apenas $3 \%$ dos trabalhos analisados foram ali realizados. Assim, as categorias APA e RPPN possibilitam maiores oportunidades e potencialidades para o desenvolvimento das comunidades humanas locais, tanto pelo número de UCs dessas categorias quanto pelas extensões de áreas protegidas e ambientes diferentes.

Outro fato a salientar é que de acordo com o SNUC, as RPPNs permitem visitação com objetivos turísticos, recreativos e educacionais, enquanto que as APAs, além da permissão de visitação, admitem o uso dos recursos naturais de maneira sustentável. A realização dessas atividades pela população local pode gerar oportunidades de desenvolvimento local para a complementação da geração de renda e emprego, resultando no aumento da qualidade de vida sem prejuízo à conservação ambiental.

Dos nove trabalhos realizados nas UCs de Uso Sustentável (tabela 4), três foram realizados no litoral e com enfoque no saber sobre o uso de plantas por pescadores artesanais e/ou caiçaras. Pelo menos em duas dessas áreas já existiam estudos sobre a vegetação e a flora local, como a APA Cairuçu e a RESEX de Arraial do Cabo (área limítrofe ao Parque Estadual da Costa do Sol), o que respalda a pesquisa sobre a flora útil local. Além dos artigos publicados, outras ferramentas que não devem ser negligenciadas na escolha de áreas para desenvolvimento de novos projetos são as consultas aos herbários virtuais e a Lista de Espécies da Flora do Brasil. No caso do estado do Rio de Janeiro, essa ferramenta é fundamental, pois, das 216 UCs de Uso Sustentável distribuídas pelo estado, 24\% são RPPNs concentradas em três municípios da Região Serrana (figura 1). Essa região é também uma das mais bem conhecidas em relação à sua riqueza florística (citada em diversos artigos científicos) e à densidade de coletas botânicas, de acordo com a consulta ao Banco de Dados JABOT do Jardim Botânico do Rio de Janeiro. 
Muito embora as UCs de Proteção Integral tenham o objetivo básico, de acordo com o SNUC, de "[...] preservar a natureza, sendo admitida apenas o uso indireto dos seus recursos naturais [...]", constatamos que em $16,4 \%$ delas (tabelas 1, 3 e 4) foram desenvolvidas $82,9 \%$ das pesquisas etnobotânicas. Esse dado revela ainda (tabela 3) que trinta dos trabalhos foram realizados após o ano 2000, ou seja, são estudos recentes em UCs criadas recentemente, enquanto no Parque Nacional de Itatiaia e na Rebio Poço das Antas, as mais antigas dentre as UCs estudadas (tabela 3), foram realizadas $20,5 \%$ das pesquisas. Tal fato demonstra que nas UCs de Proteção Integral há possibilidades de desenvolvimento de pesquisas, mas com limitação de ações e aplicações, já que não podem estar em conflito com as premissas desta categoria conforme o SNUC. Outro fato importante a destacar, no que concordamos com a observação de Luz e Elias (2014), é a necessidade de consulta ao Plano de Manejo (se existir!) da UC a ser pesquisada, de forma que seja verificada ali as prioridades de pesquisa da UC. Essa forma de agir torna o pesquisador um parceiro e não um simples usuário da UC, na medida em que sua pesquisa, quando possível, auxilia na gestão, proteção e conservação da área.

As questões socioeconômicas estão diretamente relacionadas às UCs, sendo os principais tópicos: a pressão demográfica no entorno dos limites do parque; as atitudes da população local, no entorno e dentro da UC; a economia local e a dependência de atividades extrativas. Nesse aspecto, a etnobotânica tem um papel fundamental para promover a conciliação do desenvolvimento humano, sobrevivência cultural e a conservação dos recursos vegetais em vários níveis - variedades, espécies, populações (Minnis, 2000; Tuxill e Nabhan, 2001). 


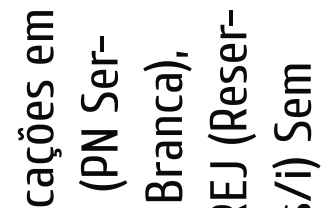
응묘

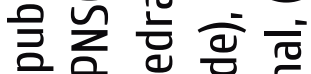

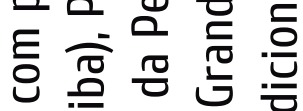

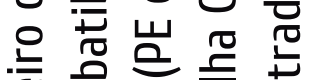

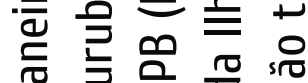
콕 岩 응 음 菂 음 可 는 응 은 뜸흥 응 䒕 范 范 凹之 을은 는을

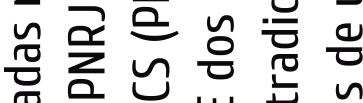

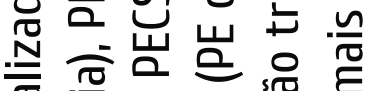

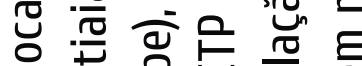
垔岩岩 응 흥 흔 즌

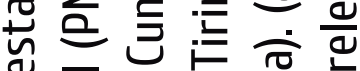
츰 응 응 든 늠 1 뜬 응 产

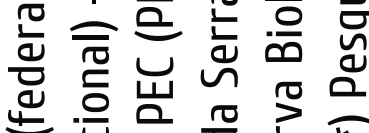

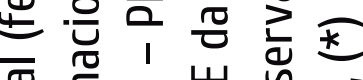

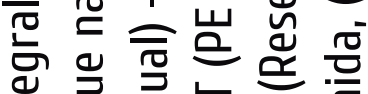

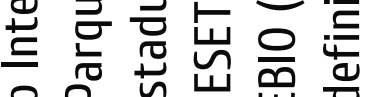

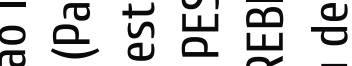
㟧 은

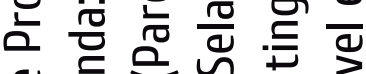

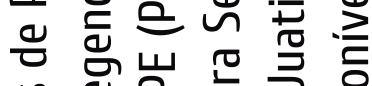

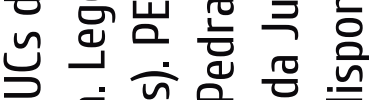

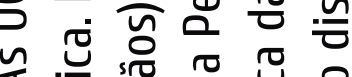

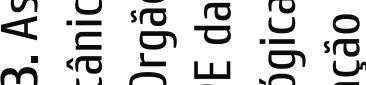

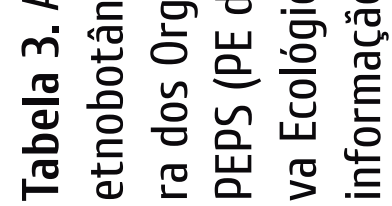

\begin{tabular}{|c|c|c|c|c|c|}
\hline 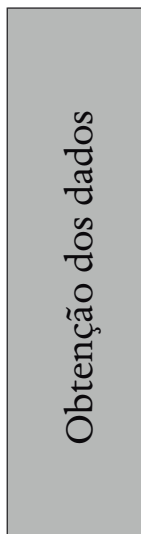 & 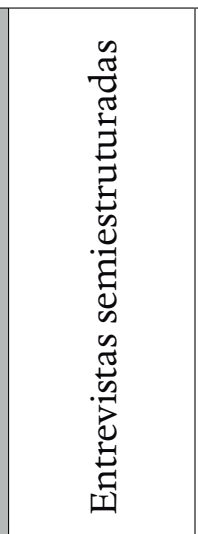 & 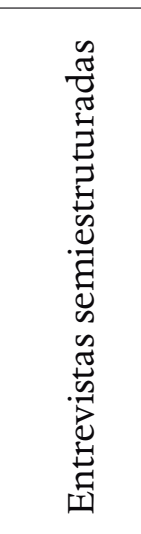 & 5 & 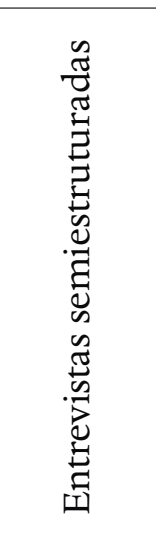 & 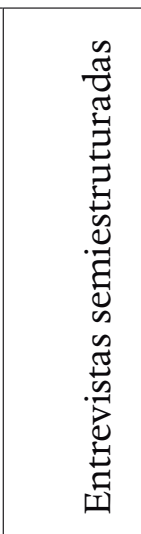 \\
\hline 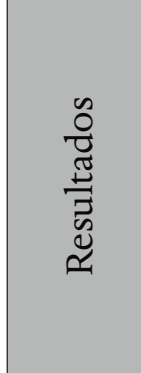 & 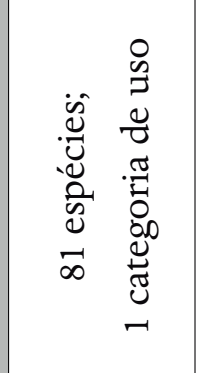 & 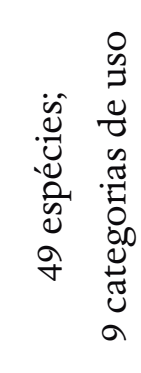 & 5 & 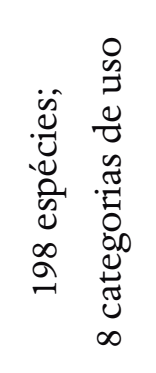 & 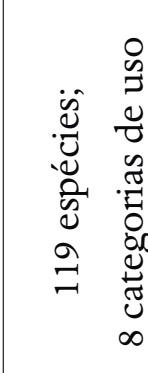 \\
\hline 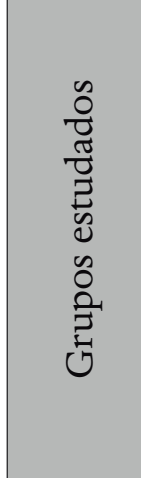 & 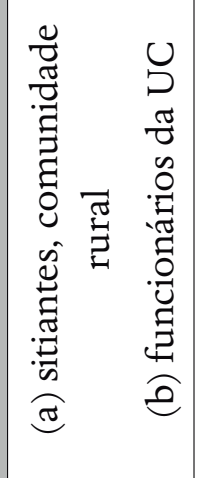 & 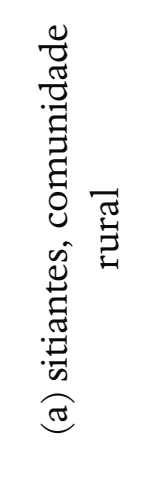 & 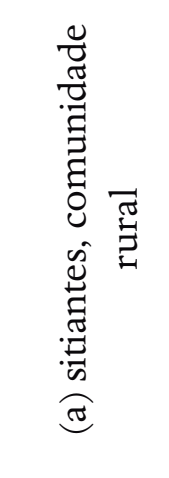 & 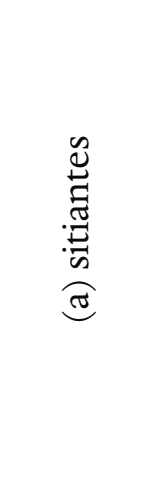 & 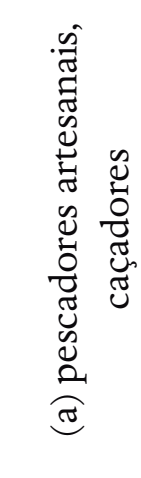 \\
\hline 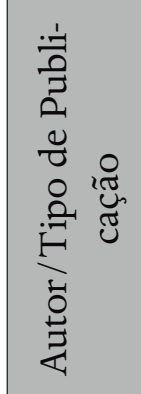 & 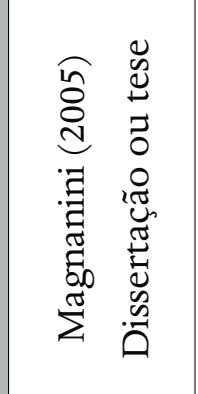 & 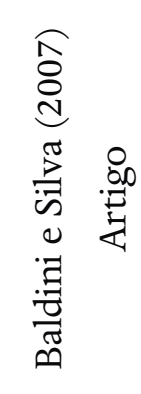 & 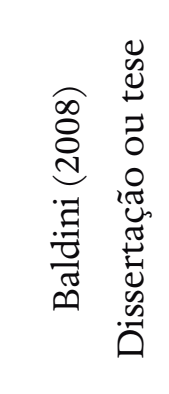 & 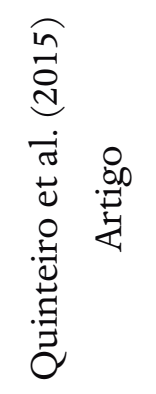 & 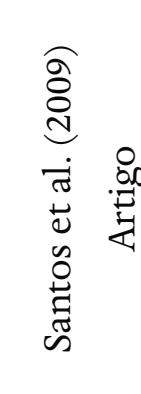 \\
\hline 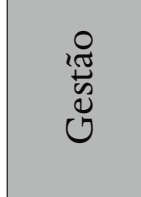 & & & & & 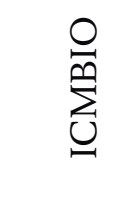 \\
\hline$\stackrel{\square}{:}$ & & & & & \\
\hline
\end{tabular}




\begin{tabular}{|c|c|c|c|c|c|c|c|}
\hline $\begin{array}{l}0 \\
0 \\
0 \\
\pi \\
0 \\
0 \\
0 \\
0 \\
0 \\
0 \\
0 \\
0 \\
0 \\
0 \\
0 \\
0\end{array}$ & 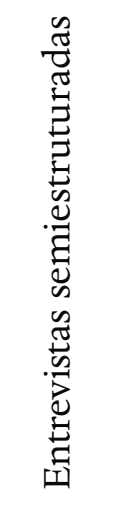 & 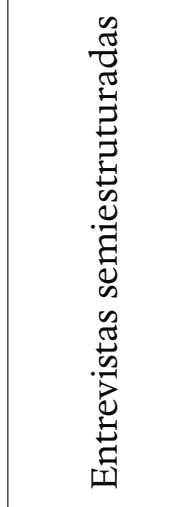 & 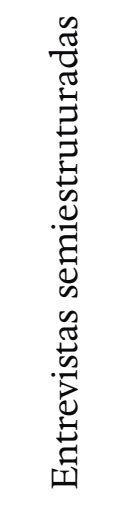 & 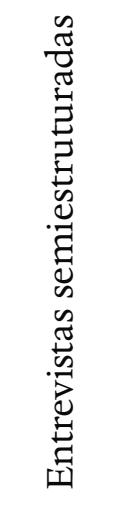 & 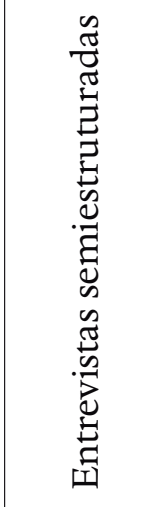 & 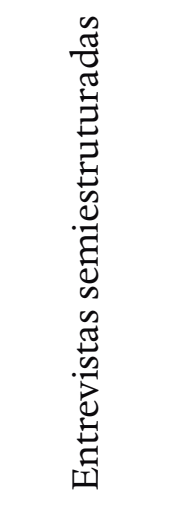 & 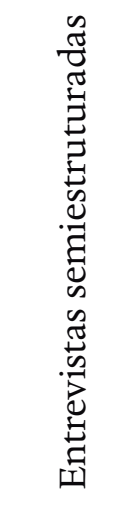 \\
\hline 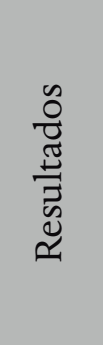 & 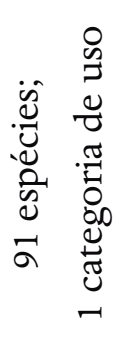 & 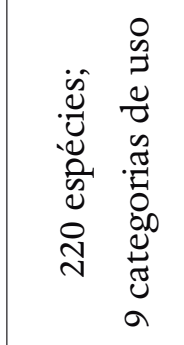 & 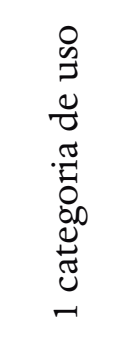 & 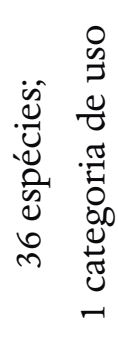 & 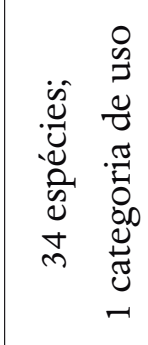 & 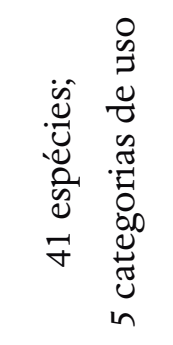 & 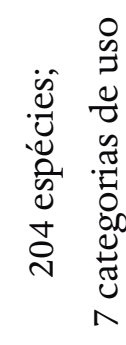 \\
\hline $\begin{array}{l}0 \\
0 \\
\frac{0}{0} \\
\frac{0}{0} \\
己 \\
0 \\
0 \\
0 \\
0 \\
0 \\
\vdots \\
0 \\
0\end{array}$ & $\frac{-r}{n}$ & 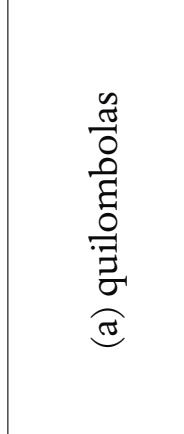 & 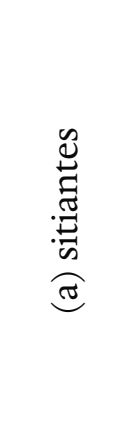 & 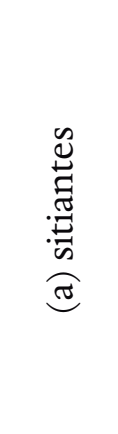 & 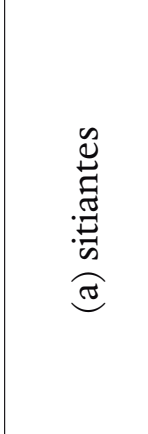 & 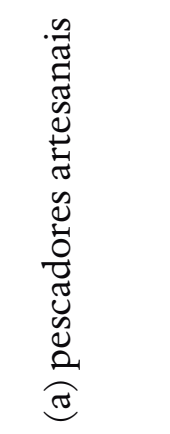 & 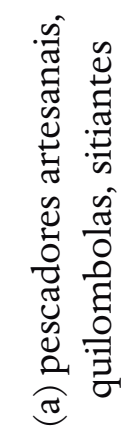 \\
\hline 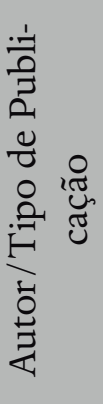 & 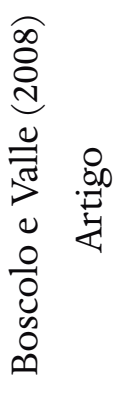 & 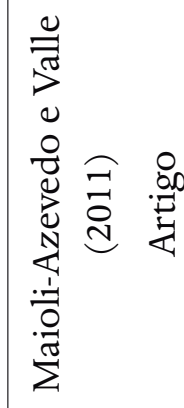 & 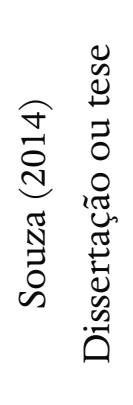 & 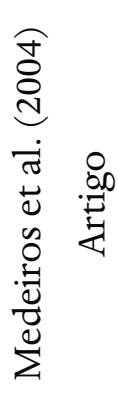 & 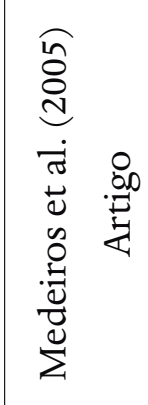 & 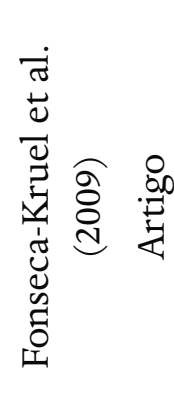 & 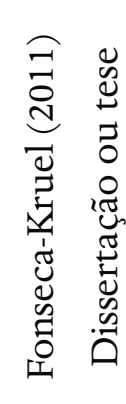 \\
\hline 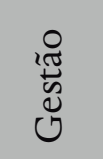 & & $\frac{0}{\sum_{i}}$ & $\stackrel{0}{\sum_{0}^{0}}$ & & 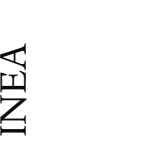 & & \\
\hline טִ & & $\underset{z}{z}$ & $\begin{array}{l}0 \\
\mathscr{Z} \\
\tilde{L}_{1}\end{array}$ & & 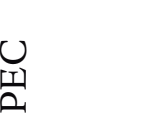 & & \\
\hline
\end{tabular}




\begin{tabular}{|c|c|c|c|c|c|c|c|}
\hline 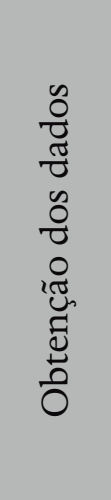 & 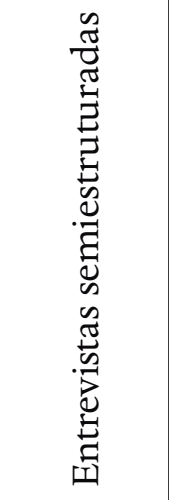 & 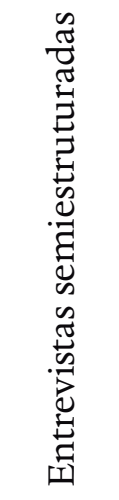 & 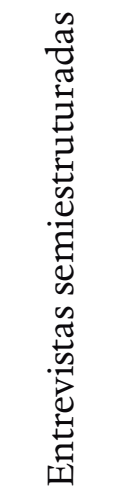 & $\vec{\omega}$ & $\frac{-1}{\infty}$ & $\frac{\vec{r}}{\infty}$ & $\vec{r}$ \\
\hline 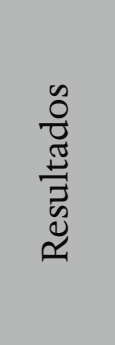 & 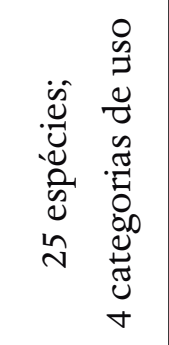 & 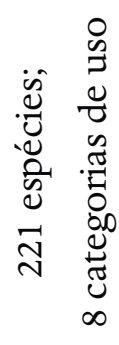 & 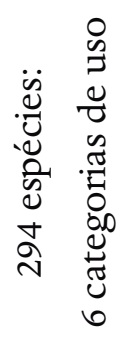 & 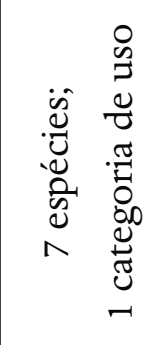 & 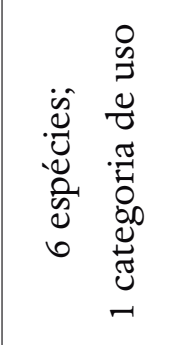 & 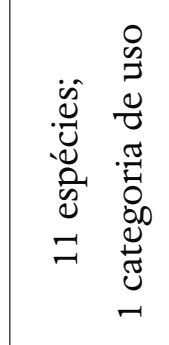 & 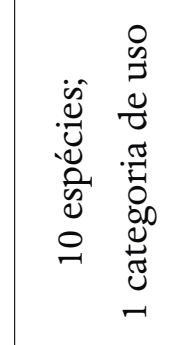 \\
\hline 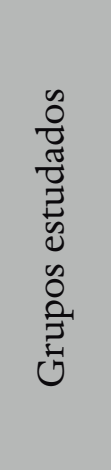 & 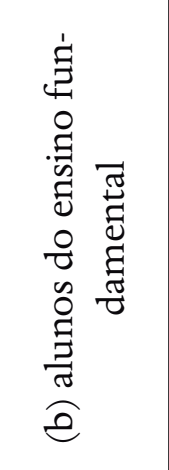 & 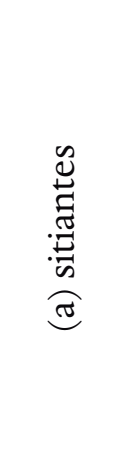 & 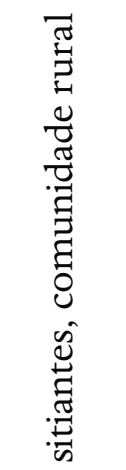 & $\overrightarrow{-m}$ & $\frac{-1}{\infty}$ & $\frac{\vec{n}}{\infty}$ & $\frac{\vec{m}}{\omega}$ \\
\hline 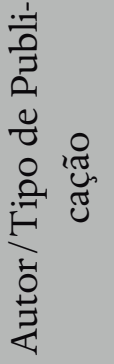 & 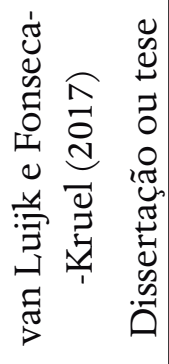 & 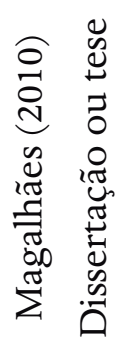 & 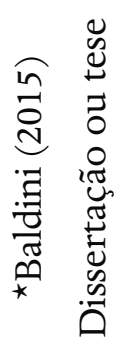 & 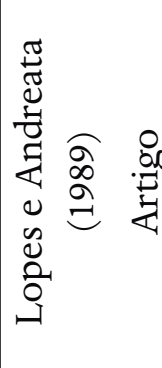 & 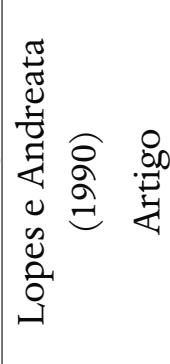 & 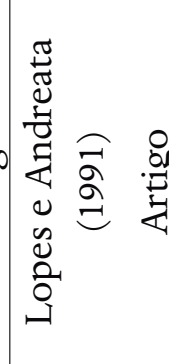 & 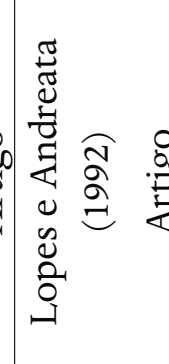 \\
\hline 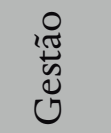 & 嵒 & $\begin{array}{l}\text { 崩 } \\
\text { 号 }\end{array}$ & $\begin{array}{l}\text { 㭊 } \\
\text { 乙 }\end{array}$ & \multicolumn{4}{|c|}{ 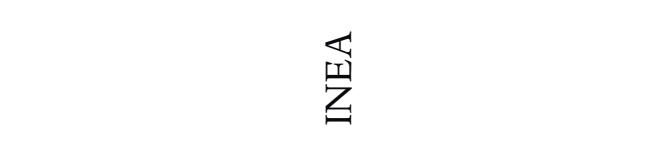 } \\
\hline$\stackrel{\cup}{\cup}$ & 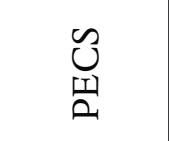 & $\begin{array}{l}\stackrel{0}{2} \\
\frac{1}{2}\end{array}$ & $\frac{n}{\tilde{0}}$ & \multicolumn{4}{|c|}{ 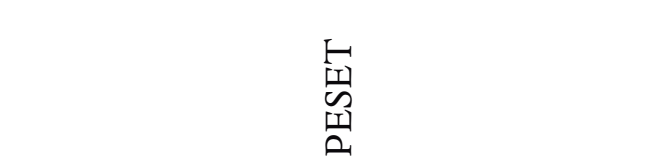 } \\
\hline
\end{tabular}




\begin{tabular}{|c|c|c|c|c|c|c|c|c|}
\hline 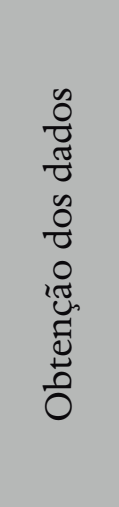 & $\stackrel{-r}{\infty}$ & 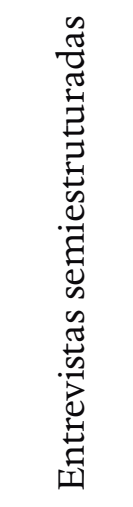 & 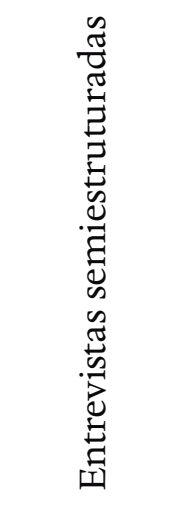 & 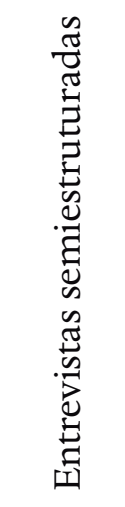 & 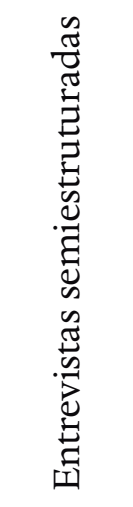 & 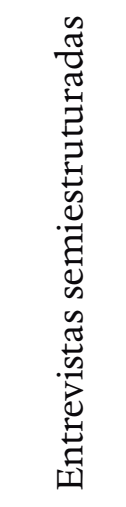 & 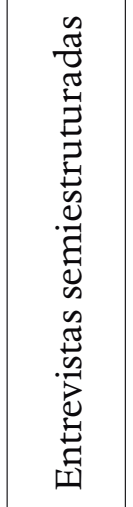 & 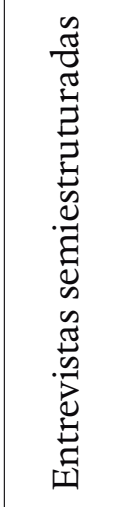 \\
\hline 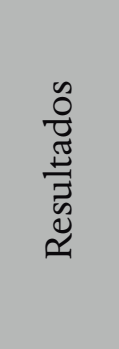 & 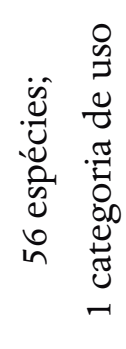 & 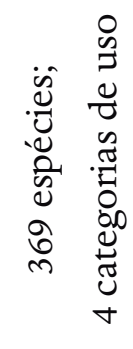 & 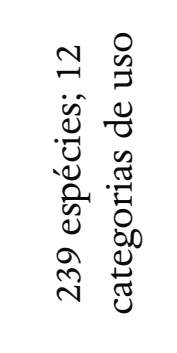 & 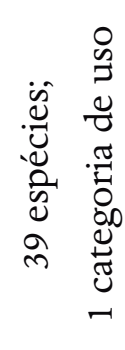 & 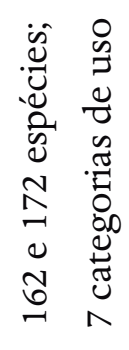 & 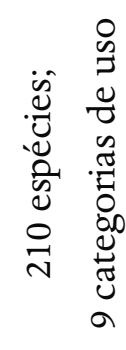 & 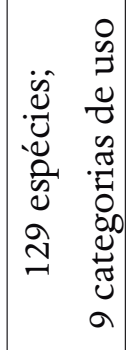 & 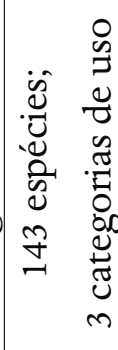 \\
\hline 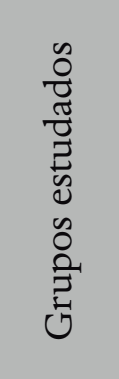 & $\frac{\vec{n}}{\infty}$ & 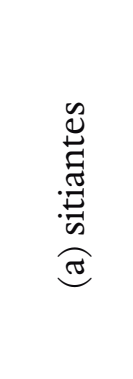 & 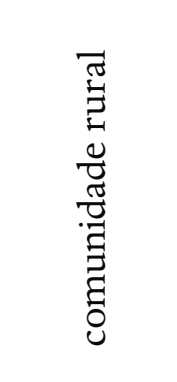 & 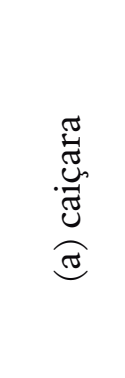 & $\frac{-r}{\infty}$ & 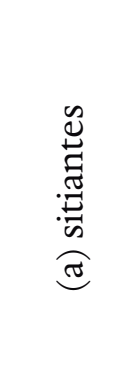 & 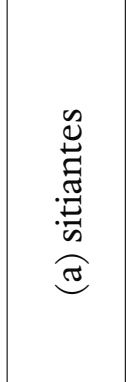 & 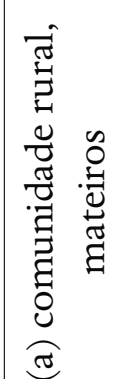 \\
\hline 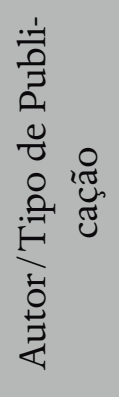 & 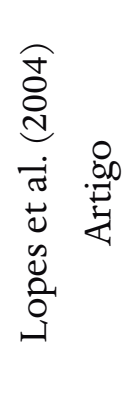 & 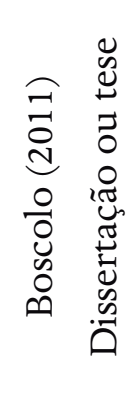 & 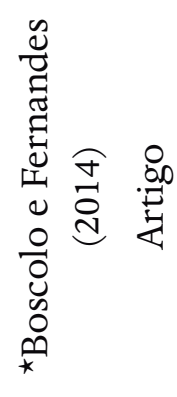 & 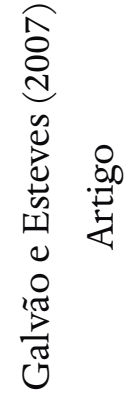 & 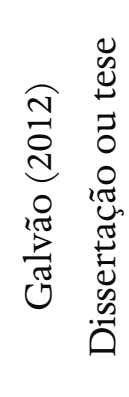 & 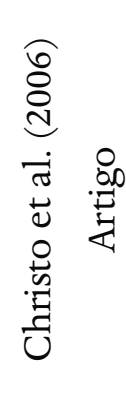 & 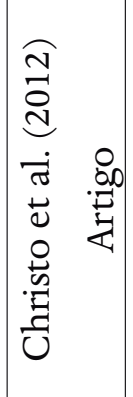 & 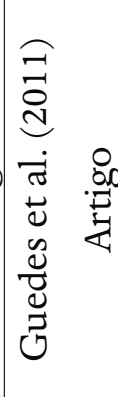 \\
\hline 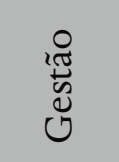 & $\begin{array}{l}\mathbb{I} \\
\text { 兊 }\end{array}$ & $\begin{array}{l}\mathbb{I} \\
\text { 岌 }\end{array}$ & 壳 & & & & $\sum_{0}^{0}$ & \\
\hline ט & 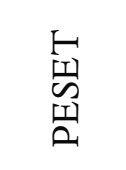 & 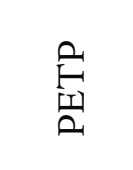 & 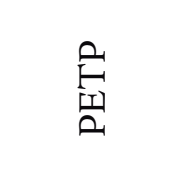 & & & & 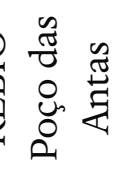 & \\
\hline
\end{tabular}




\begin{tabular}{|c|c|c|c|c|c|c|c|}
\hline 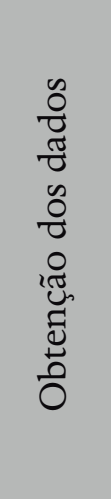 & 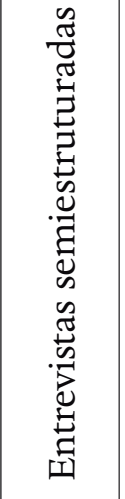 & 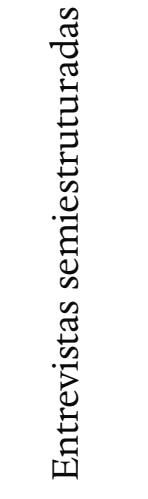 & 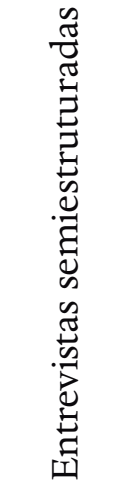 & 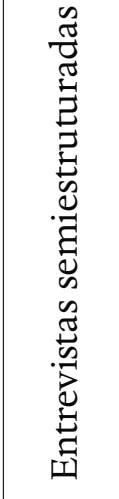 & 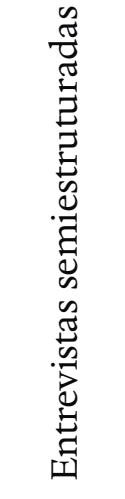 & 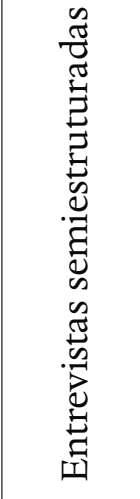 & 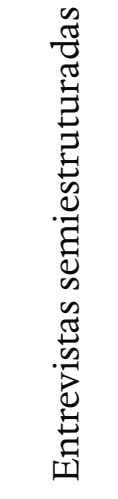 \\
\hline 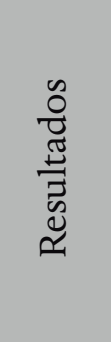 & 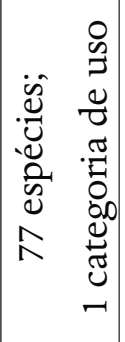 & 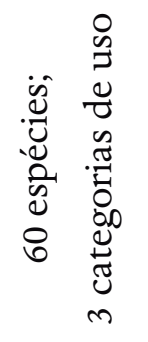 & 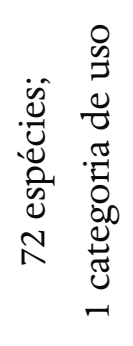 & 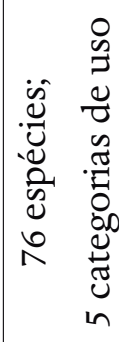 & 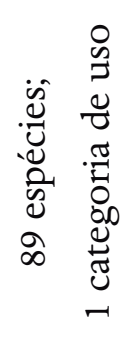 & 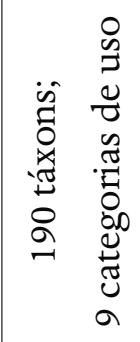 & $\frac{-1}{\infty}$ \\
\hline 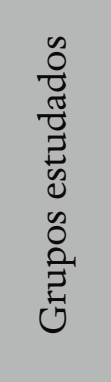 & 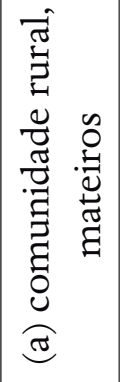 & 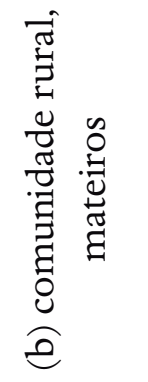 & 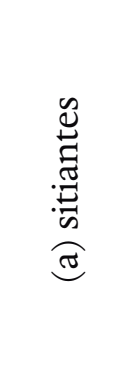 & 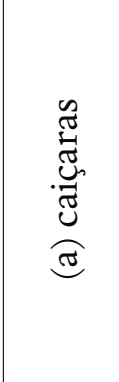 & 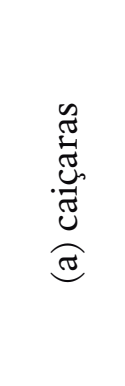 & 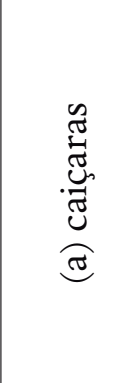 & 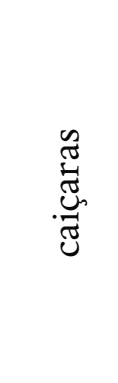 \\
\hline 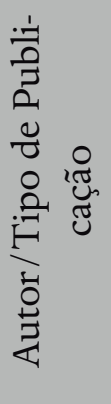 & 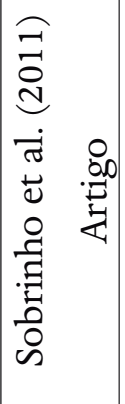 & 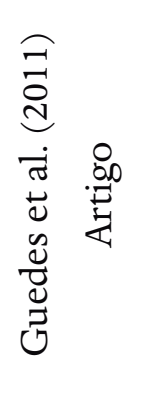 & 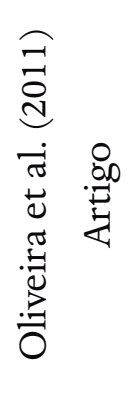 & 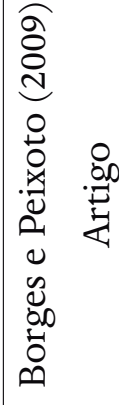 & 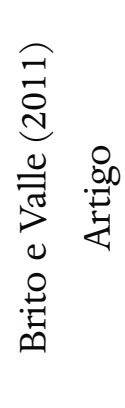 & 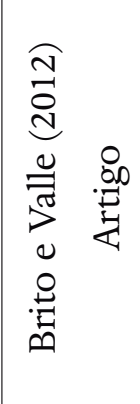 & 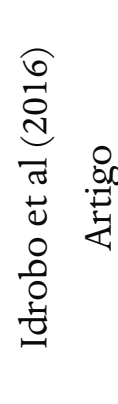 \\
\hline 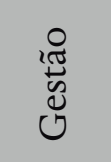 & & $\stackrel{0}{\sum_{0}^{0}}$ & & & & 这 & \\
\hline$\stackrel{\cup}{\square}$ & & 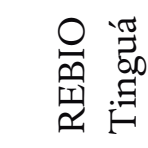 & & & & 四 & \\
\hline
\end{tabular}




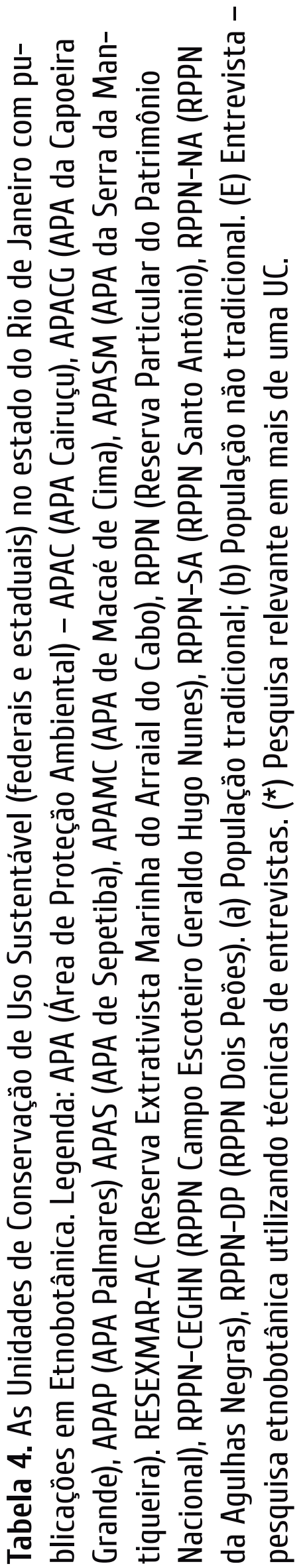

\begin{tabular}{|c|c|c|c|c|c|}
\hline 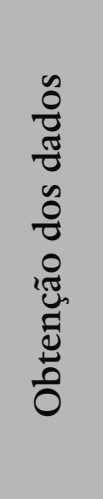 & 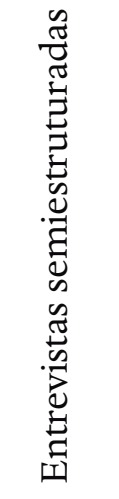 & 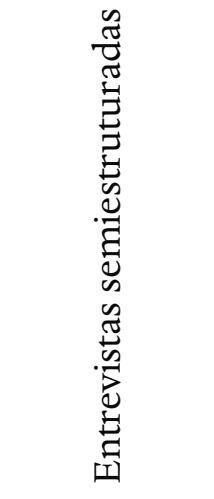 & 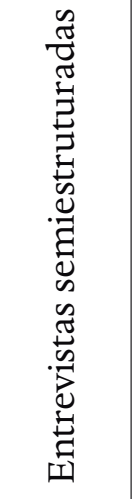 & 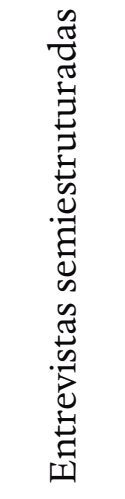 & 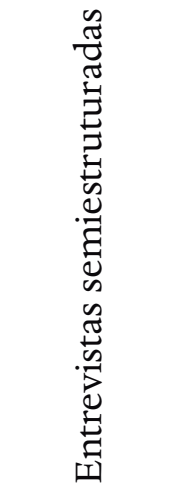 \\
\hline 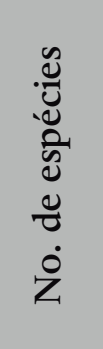 & 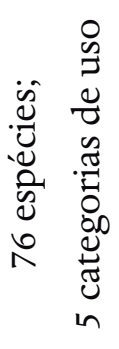 & 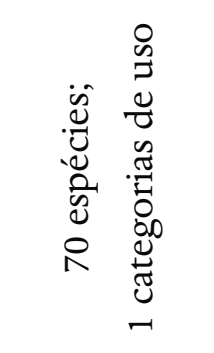 & 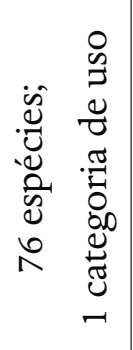 & 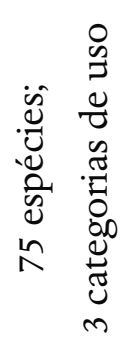 & 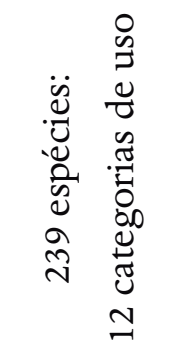 \\
\hline 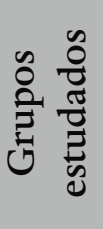 & 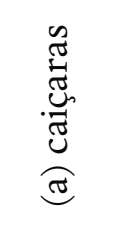 & 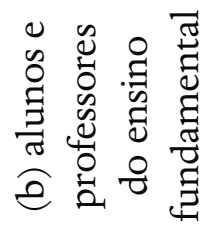 & 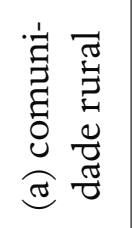 & 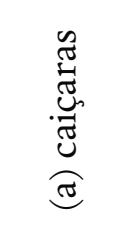 & 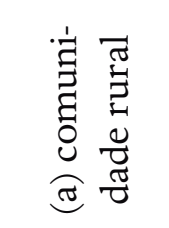 \\
\hline$\stackrel{0}{0}$ & 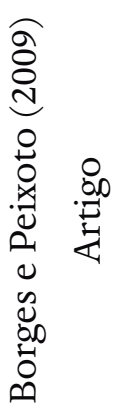 & 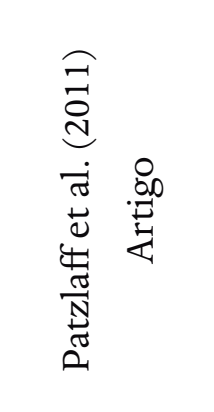 & 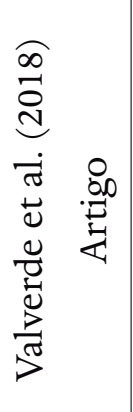 & 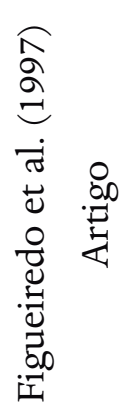 & 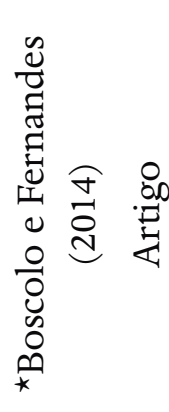 \\
\hline $\begin{array}{l}\stackrel{\mathscr{J}}{\mathscr{J}} \\
\text { }\end{array}$ & $\sum_{0}^{0}$ & 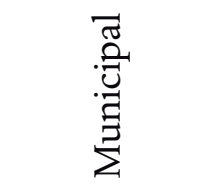 & 兄 & $\begin{array}{l}\text { 至 } \\
\text { Z }\end{array}$ & $\begin{array}{l}\text { 崩 } \\
\text { Z }\end{array}$ \\
\hline ט & 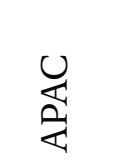 & $\begin{array}{l}\text { U } \\
\text { 岁 }\end{array}$ & 竞 & 这 & 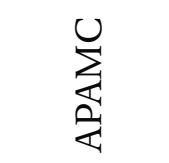 \\
\hline
\end{tabular}




\begin{tabular}{|c|c|c|c|c|c|c|c|}
\hline 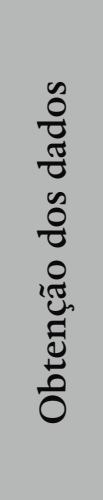 & 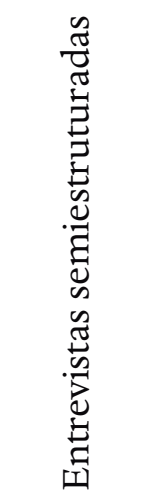 & 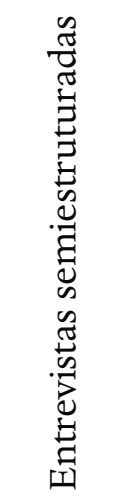 & 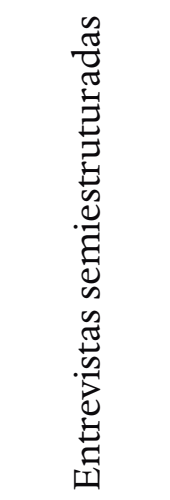 & 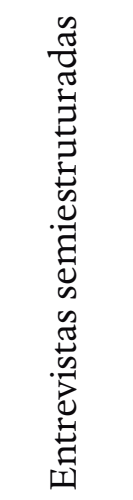 & \multicolumn{3}{|c|}{ 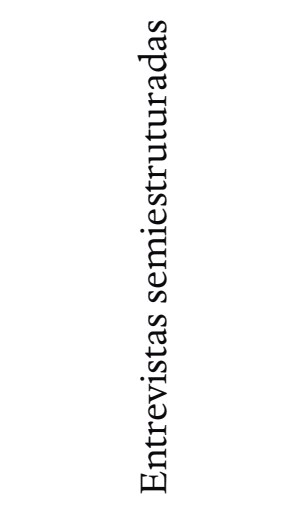 } \\
\hline 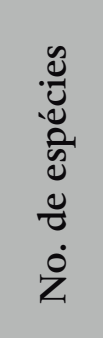 & 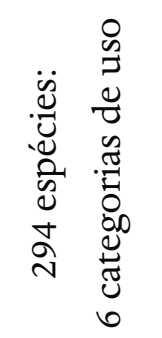 & 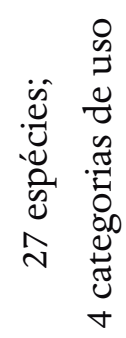 & 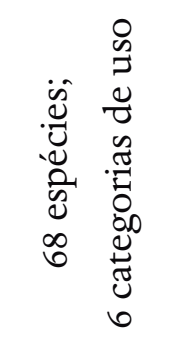 & 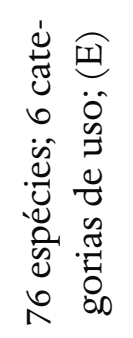 & & 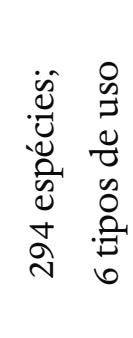 & \\
\hline 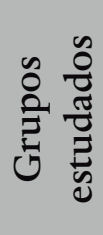 & 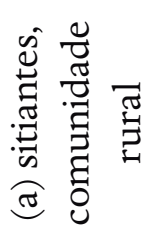 & 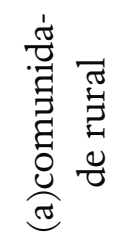 & 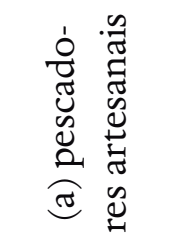 & 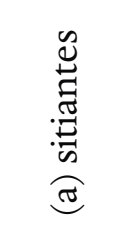 & & 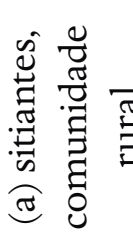 & \\
\hline$\stackrel{5}{\stackrel{0}{Z}}$ & 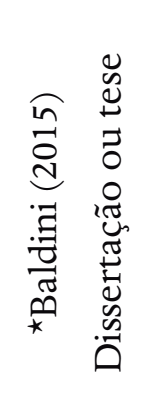 & 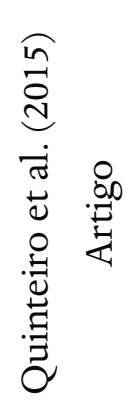 & 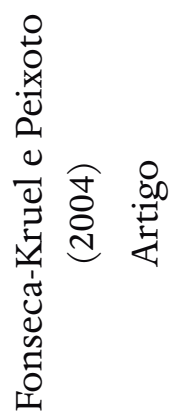 & 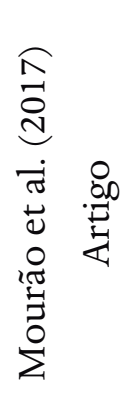 & & 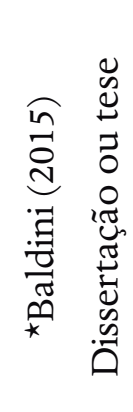 & \\
\hline 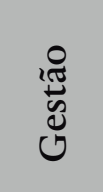 & $\stackrel{0}{\sum_{0}^{0}}$ & & $\stackrel{0}{\sum_{0}^{0}}$ & 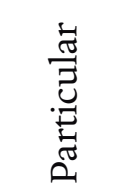 & & 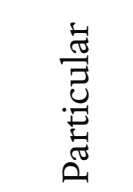 & \\
\hline טיל & 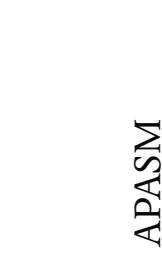 & & 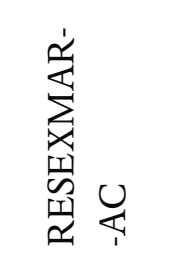 & 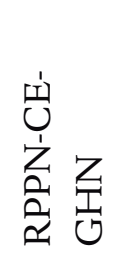 & 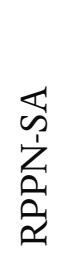 & 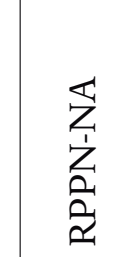 & $\begin{array}{l}\text { Oि } \\
\text { خे } \\
\text { خे }\end{array}$ \\
\hline
\end{tabular}




\section{Consideraçôes finais}

Cresce, no Brasil, o número de áreas protegidas e das pesquisas científicas nessas áreas, mas, dado o tamanho do país, da diversidade de biomas e da biodiversidade embutida, é preciso mudar o paradigma das atividades científicas nesses espaços tão necessários nos dias atuais. As comparações e análises aqui realizadas permitiram identificar lacunas tanto nos conhecimentos acadêmicos como em ações para conservação da biodiversidade no estado do Rio de Janeiro. Há demanda de estudos sobre o conhecimento tradicional e local associado à biodiversidade fluminense para que estes integrem o processo de gestão das UCs. Com isso, o conhecimento tradicional pode auxiliar na elaboração de regras (identificando zonas de recursos vegetais) e no plano de manejo das UCs, em ações de educação ambiental e intensificação de medidades de proteção ambiental.

As pesquisas etnobotânicas em unidades de conservação fluminenses poderiam ser prioritariamente dirigidas para as UCs, onde as finalidades sejam mais afeitas ao uso dos recursos, como as UCs de Uso Sustentável. Entretanto, isso não significa que as UCs de Proteção Integral não sejam estudadas sob esse aspecto, já que tanto as UCs de Proteção Integral quanto as de desenvolvimento sustentável do território fluminense apresentam em seu histórico algum uso pretérito de recursos pelas populações tradicionais. Além disso, a ocupação desses territórios precede em muito o estabelecimento de unidades de conservação no Brasil. Independente da categoria de UC a ser investigada, é recomendável que o pesquisador não se comporte como simples usuário, ${ }^{16}$ mas que, na medida do possível, sua pesquisa se traduza em ações para a proteção, gestão e conservação da UC. Para tanto, o plano de manejo da UC (quando houver) é leitura fundamental na formulação da pesquisa.

${ }^{16}$ Luz e Elias, 2014. 


\section{Referências}

ALBUQUERQUE, U. P. Introdução à etnobotânica. 2 ed. Rio de Janeiro: Interciência, 2005.

ALCORN, J. B. "The scope and aims of ethnobotany in a developing world”. In SCHULTES, R. E. e REIS S. V. (eds.). Ethnobotany: evolution of a discipline. Cambridge: Timber Press, 1995, pp. 23-39.

ALEXIADES, M. N. e SHELDON, J. W. (eds.). Ethnobotanical research: a field manual. Nova Iorque: The New York Botanical Garden, 1996.

ALVES, R. P. e HANAZAKI, N. "Áreas protegidas marinho-costeiras de Santa Catarina sob a perspectiva das populações locais: contribuições da literatura”. Ambiente \& Sociedade, v. 18, n. 4, pp. 97-118, 2015.

BALDINI, K. B. L. Relação homem-natureza em grupos rurais (caipiras, sitiantes e pequenos agricultores) na Mata Atlântica e conservação da biodiversidade em um município do Sul Fluminense, $R J$ (tese). Universidade Federal Rural do Rio de Janeiro, 2015.

e SILVA, J. G. "Madeiras do Parque Nacional do Itatiaia: etnobotânica e conservação dos recursos naturais". Floresta e Ambiente, v. 14, n. 2, pp. 35-48, 2007.

BARROS, W. D. Parques Nacionais do Brasil, Série Documentária n. 1, Rio de Janeiro, Ministério da Agricultura, 1952.

BAUMGRATZ, J. F. A et al. Catálogo das espécies de plantas vasculares e briófitas do estado do Rio de Janeiro. Instituto de Pesquisas Jardim Botânico do Rio de Janeiro, 2014. Disponível em: http://florariojaneiro.jbrj.gov. br/. Acesso em: 20 fev. 2015.

BERKES, F. et al. "Traditional ecological knowledge, biodiversity, resilience and sustainability”. In PERRINGS C. S. et al. (eds.). Biodiversity conservation: problems and policies. Dordrecht: Kluwer Academic Press, 1995, pp. 281-300.

BITTENCOURT, L. A. F. e PAULA, A. "Análise cienciométrica de produção científica em unidades de conservação federais no Brasil”. Enciclopédia Biosfera, v. 8, n. 14, pp. 2044-54, Goiânia, 2012. 
BORGES, R. e PEIXOTO, A. L. "Conhecimento e uso de plantas em uma comunidade caiçara do litoral sul do estado do Rio de Janeiro, Brasil". Acta Botanica Brasílica, v. 23, n. 3, pp. 769-79, 2009.

BOSCOLO, O. H. Estudos etnobotânicos nas comunidades de Galdinópolis e Rio Bonito, Nova Friburgo, RJ (tese). UFRJ, 2011.

e FERNANDES, L. "Appropriation of biodiversity and traditional knowledge: a case study of two rural communities in Rio de Janeiro state, Brazil”. Scientia Plena, v. 10, n. 11, nov. 2014.

e SENNA-VALLE, L. "Plantas de uso medicinal em Quissamã, Rio de Janeiro, Brasil”. Iheringia, Série Botânica, v. 63, pp. 263-77, 2008.

BRASIL. "Lei n. ${ }^{\circ}$ 9.985, de 18 de julho de 2000". Regulamenta o artigo 225, $\S 1^{\circ}$,incisos I, II, III e VII da Constituição Federal, institui o Sistema Nacional de Unidades de Conservação da Natureza e dá outras providências. Ministério do Meio Ambiente. Brasília, 2000. Disponível em: http://www.planalto.gov.br/ccivil_03/Leis/L9985.htm. Acesso em: 27 maio 2018.

BRITO, M. R. de e SENNA-VALLE, L. "Plantas medicinais utilizadas na comunidade caiçara da Praia do Sono, Paraty, Rio de Janeiro, Brasil”. Acta Botanica Brasílica, v. 25, n. 2, pp. 363-72, 2011.

e __ . "Diversity of plant knowledge in a caiçara community from the Brazilian Atlantic Forest coast". Acta Botanica Brasílica, v. 26, n. 4, pp. 375-747, Feira de Santana, out.-dez. 2012.

CHRISTO, A. G. et al. "Uso de recursos vegetais em comunidades rurais limítrofes à reserva biológica de Poço das Antas, Silva Jardim, Rio de Janeiro: estudo de caso na gleba Aldeia Velha”. Rodriguésia, v. 57, pp. 519-42, Rio de Janeiro, 2006.

et al. "Evidence for conservation and sustainable use in a fragment of the Atlantic Forest in southeastern Brazil by a traditional human group". SpringerPlus, v. 1, pp. 1-21, 2012.

CUNNINGHAM, A. Applied ethnobotany: people, wild plant use and conservation. London: Earthscan, 2000. 
FIGUEIREDO, G. M. et al. "Ethnobotany of Atlantic Forest coastal communities: II. Diversity of plant uses at Sepetiba bay (SE Brazil)". Human Ecology, v. 25, pp. 353-60, 1997.

FONSECA-KRUEL, V. S. Etnobotânica nas restingas no Centro de Diversidade Vegetal de Cabo Frio, Rio de Janeiro, Brasil (tese). Escola Nacional de Botânica Tropical, 2011.

e PEIXOTO, A. L. "Etnobotânica na Reserva Extrativista Marinha de Arraial do Cabo, RJ, Brasil”. Acta Botanica Brasílica, v. 18, pp. 177-90, 2004.

et al. "Quantitative ethnobotany of a restinga forest fragment in Rio de Janeiro, Brasil”. Rodriguésia, v. 60, pp. 137-41, 2009.

FORD, R. I. "Ethnobotany: historical diversity and synthesis". In et

al. (eds.). The nature and status of ethnobotany: Annals of Arnold Arboretum - Anthropological Papers, v. 67, pp. 33-49, Michigan, 1978.

GALVÃO, M. N. e ESTEVES, R. L. "Plantas medicinais utilizadas pela comunidade de Vila Dois Rios, Ilha Grande, Rio de Janeiro, Brasil”. Bradea, v. 12, p. 10, 2007.

Etnobotânica na Ilha Grande, Angra dos Reis, Rio de Janeiro: uso de recursos vegetais na Vila do Abraão e Praia Longa (tese). UFRJ, 2012.

GUEDES-BRUNI, R. R. et al. "Mateiros, matas e reservas: saber local e conservação”. In PEIXOTO, A. L. e SILVA, I. M. (orgs.). Saberes e usos de plantas: legados de atividades humanas no Rio de Janeiro. 1 ed. Rio de Janeiro: Editora PUC-Rio, 2011, pp. 93-128.

HANAZAKI, N. et al. "Diversity of plant uses in two caiçara communities from the Atlantic Forest coast, Brazil". Biodiversity and Conservation, v. 9, pp. 597-615, 2000.

ICMBIO - Instituto Chico Mendes de Conservação da Biodiversidade. Disponível em: http://www.brasil.gov.br/editoria/turismo/2018/02/ parques-nacionais-tem-recorde-de-visitacao-conheca-algumas-das-atracoes. Acessado em: 22 maio 2018.

IDROBO, C. J. et al. "Produced natures through the lens of biodiversity conservation and tourism: the Ponta Negra caiçara in the Atlantic Forest coast of Brazil”. Local Environment, v. 21, n. 9, pp. 1132-50, 2016. 
INEA - Instituto Estadual do Ambiente. Disponível em: http://www. inea.rj.gov.br/Portal/Agendas/BIODIVERSIDADEEAREASPROTEGIDAS/UnidadesdeConservacao/index.htm. Acesso em: 22 maio 2018.

Secretaria do ambiente. RPPN reconhecidas pelo Instituto Estadual do Ambiente. Disponível em: http://www.inea.rj.gov.br/cs/groups/ public/documents/document/zwew/mtuz/ edisp/inea0153384.pdf. Acesso em: 22 maio 2018.

LOPES. R. C. e ANDREATA, R. H. P. "Plantas medicinais do Pico Alto Mourão I”. Eugeniana, v. 16, pp. 1-9, Rio de Janeiro, 1989.

. "Plantas medicinais do Pico Alto Mourão II". Eugeniana, v. 17, pp. 15-21, Rio de Janeiro, 1990.

. "Plantas Medicinais do Pico Alto Mourão III". Eugeniana, v. 18, pp. 21-30, Rio de Janeiro, 1991.

. "Plantas Medicinais do Pico Alto Mourão IV". Eugeniana, v. 19, pp. 1-10, Rio de Janeiro, 1992.

et al. "Plantas ornamentais ocorrentes na Mata Atlântica do morro Alto Mourão, Niterói/Maricá, Rio de Janeiro”, Publicações Avulsas do Museu Nacional, v. 102, pp. 3-14, Rio de Janeiro, 2004.

LUIJK N. V. e FONSECA-KRUEL, V.S. Transmissão do conhecimento etnobotânico sobre as plantas úteis da restinga de Arraial do Cabo, RJ (monografia). Instituto Federal Fluminense, 2017.

LUZ, A. P. e ELIAS, H. T. "Pesquisa científica em unidades de conservação”. Revista Agropecuária Catarinense, v. 27, n. 1, pp. 21-4, 2014.

MAGALHÃES, A. C. Etnobotânica, saberes locais e agricultura no contexto de uma floresta urbana: Maciço da Pedra Branca, RJ (dissertação). Pontifícia Universidade Católica do Rio de Janeiro, 2010.

MAGNANINI, C. Etnobotânica em Itatiaia, Rio de Janeiro: plantas medicinais do Parque Nacional do Itatiaia e áreas do entorno (dissertação). Universidade Federal Fluminense, 2005.

MAIOLI-AZEVEDO, V. e SENNA-VALLE, L. "Quilombolas da Fazenda Machadinha: tradição e uso dos recursos vegetais”. In PEIXOTO, A. 
L. e SILVA, I. M. (orgs.). Saberes e usos de plantas: legados de atividades humanas no Rio de Janeiro, v. 1, pp. 129-72, Rio de Janeiro, 2011.

MEDEIROS, M. F. T. et al. "Plantas medicinais e seus usos pelos sitiantes da Reserva Rio das Pedras, Mangaratiba, RJ, Brasil". Acta Botanica Brasílica, v. 18, n. 2, pp. 391-9, 2004.

.et al. Flora medicinal dos sitiantes da Reserva Particular do Patrimônio Natural do Rio das Pedras, Mangaratiba, Rio de Janeiro, Brasil: taxonomia e aspectos etnobotânicos",. Publicações Avulsas do Museu Nacional, v. 106, pp. 1-24, Rio de Janeiro, 2005.

MMA - Ministério do Meio Ambiente. Cadastro Nacional de Unidades de Conservação. Disponível em: http://www.mma.gov.br/areas-protegidas/cadastro-nacional-de-ucs. Acesso em: 22 maio 2018.

MOURÃO, M. D. S. et al. "Conhecimento local e uso dos recursos vegetais na comunidade Sertão, Magé, Rio de Janeiro”. Revista Fitos Eletrônica, pp. 1-126, 2017.

OLIVEIRA, L. S. et al. "Plantas medicinais como recurso terapêutico em comunidade do entorno da Reserva Biológica do Tinguá, RJ, Brasil: metabólitos secundários e aspectos farmacológicos". InterSciencePlace, v. 1, n. 17, 2015.

PATZLAFF, R. G. et al. "O saber local sobre plantas de uso medicinal em uma escola pública no entorno de um fragmento de floresta atlântica, em Guaratiba, Rio de Janeiro, RJ”. In PEIXOTO, A. L. e SILVA, I. M. (orgs.). Saberes e usos de plantas: legados de atividades humanas no Rio de Janeiro. 1 ed. Rio de Janeiro: Editora PUC-Rio, 2011, pp. 173-224.

QUINTEIRO, M. M. C. et al. "Inventory and implications of plant use for environmental conservation in Visconde de Maua, Serra da Mantiqueira, Brazil”. Ethnobotany Research and Applications, v. 14, pp. 27-47, 2015.

ROCHA, J. A. et al. "Etnobotânica: um instrumento para valorização e identificação de potenciais de proteção do conhecimento tradicional”. Interações, v. 16, n. 1, pp. 67-74, 2015.

RYLANDS, A. B. e BRANDON, K. "Unidades de conservação brasileiras". Megadiversidade, v. 1, n. 1, pp. 27-35, 2005. 
SANTA CATARINA. "Lei n. ${ }^{\circ} 11.986$, de 12 de novembro de 2001". Institui o Sistema Estadual de Unidades de Conservação da Natureza e adota outras providências. Florianópolis, 2001.

SANTILLI, J. "Áreas protegidas e direitos de povos e comunidades tradicionais". In BENSUSAN N. e PRATES A. (orgs.). A diversidade cabe na unidade?. Brasília: IEB, 2014, pp. 470-507.

SANTOS, M. G. et al. "Recursos vegetais da Restinga de Carapebus, Rio de Janeiro, Brasil”. Revista de Biologia Neotropical, v. 6, n. 1, pp. 35-54, 2009.

SCHULTES, R. E. e REIS, S. V. (eds.). Ethnobotany: evolution of a discipline. Cambridge: Timber Press, 1995.

SOBRINHO, F. D. A. P. et al. "Uso de plantas medicinais no entorno da Reserva Biológica de Tinguá, Nova Iguaçu, RJ”. Revista Acadêmica: Ciência Animal, v. 9, n. 2, pp. 195-206, 2011.

VALVERDE, A. V. et al. "Introdução da Fitoterapia no SUS: contribuindo com a Estratégia de Saúde da Família na comunidade rural de Palmares, Paty do Alferes, Rio de Janeiro". Revista Fitos Eletrônica, v. 12, n. 1, pp. 27-40, 2018. 


\title{
CAPÍTULO VI \\ Os saberes tradicionais e locais e as indicaçôes geográficas: 0 caso das plantas medicinais do Brasil
}

\author{
Lucia Regina Rangel de Moraes Valente Fernandes \\ Sandra Aparecida Padilha Magalhầes Fraga \\ Vanise Baptista da Costa
}

\section{Apresentaçăo}

No Brasil, o conhecimento tradicional sobre plantas medicinais ${ }^{1}$ tem origem na herança gerada por diversas etnias (indígena, negra e europeia) e gradativamente vem contribuindo para o estabelecimento da medicina tradicional brasileira - MTB. Esta construção cultural aliada a uma megabiodiversidade possibilita ao país ser um celeiro de conhecimentos sobre o uso sustentável e a conservação das espécies vegetais.

Esse conhecimento utilizado por diversas etnias indígenas e populações tradicionais está sendo alvo de estudos científicos que vêm apontando os efeitos benéficos do uso terapêutico de diversas espécies de plantas, além de gerar grande interesse das indústrias nacionais e, principalmente, das internacionais.

Por esta razão, nas últimas décadas, países detentores da biodiversidade, como o Brasil, sofrem intensamente com a apropriação dos seus recursos naturais e saberes locais e tradicionais. Verifica-se que as populações indígenas e comunidades tradicionais não vêm recebendo qualquer tipo de benefício pelos que fazem uso destes recursos para obter ganhos econômicos com produtos comerciais (MMA, 2013). Observa-se que ain-

1 De acordo com a RDC n. 14, publicada em 05 de abril de 2010, da Agência Nacional de Vigilância Sanitária (ANVISA), planta medicinal é "espécie vegetal, cultivada ou não, utilizada com propósitos terapêuticos". 
da são insuficientes os mecanismos legais de proteção ao uso e conservação da biodiversidade brasileira.

Outro aspecto importante a considerar é a criação de unidades de conservação (UC) em terras antes habitadas por várias gerações de grupos locais ou tradicionais, muitas vezes impactando na perda dos seus territórios, da sua identidade cultural e ameaçando a sua subsistência, bem como a transmissão dos seus saberes para as próximas gerações.

No Brasil, um marco importante aconteceu em 1988 com a promulgação da Constituição Federal (CF), na qual foram reconhecidos os direitos inerentes às populações indígenas e aos descendentes de escravos, os quilombolas. Não obstante abrindo um precedente de reconhecimento das populações tradicionais do país.

No contexto internacional, um grande marco ocorreu em 1992 na Conferência das Nações Unidas sobre o Meio Ambiente e o Desenvolvimento (ECO-92), realizada no Rio de Janeiro, com a assinatura da Convenção da Diversidade Biológica (CDB). Nela, foram previstas normas e princípios para reger o uso e a proteção da diversidade biológica em cada país signatário, tornando-se o principal instrumento jurídico para a proteção da biodiversidade no contexto internacional. Além disso, enfatiza a proteção aos conhecimentos associados à biodiversidade, visando garantir aos seus detentores a repartição justa e equitativa dos benefícios oriundos da utilização desses conhecimentos (MMA, 2013).

A Convenção foi assinada por 175 países durante a ECO-92 e mais tarde ratificada por 168 países, incluindo o Brasil, por meio do Decreto n. ${ }^{\circ}$ 2.519 de 16 de março de 1998 .

Em nosso país, a matéria foi regulada pela Medida Provisória n. ${ }^{\circ}$ 2.18616 de 23 de agosto de 2001, gerando um Marco Regulatório sobre o acesso à amostra de patrimônio genético nativo e acesso ao conhecimento tradicional associado. A Medida Provisória também estabeleceu o Conselho de Gestão do Patrimônio Genético - CGen, como a autoridade nacional com função normativa e deliberativa sobre as autorizações de acesso e remessa.

Em 2006, o governo federal estabeleceu diretrizes para atuar na área de plantas medicinais e fitoterápicos, aprovando a Política Nacional de Práticas Integrativas e Complementares (PNPIC, 2006) no Sistema Único de Saúde (SUS) e a Política Nacional de Plantas Medicinais e Fitoterápicos (PNPMF, 2006). Estas iniciativas governamentais visaram ao desenvolvimento de ações para assegurar o acesso seguro e o uso racional de plantas 
medicinais e fitoterápicos em nosso país, ao desenvolvimento de tecnologias e inovações, ao fortalecimento das cadeias e dos arranjos produtivos, ao uso sustentável da biodiversidade brasileira e ao desenvolvimento do Complexo Produtivo da Saúde (Decreto n. ${ }^{\circ}$ 5.813, de 22 de junho de 2006).

Apesar dos avanços, a implementação destas políticas ainda requer um longo caminho pela frente, e, para tal fim, foi desenvolvido o Programa Nacional de Plantas Medicinais e Fitoterápicos (PNPMF), objetivando colocar em prática as diretrizes priorizadas na Política Nacional de Plantas Medicinais e Fitoterápicos (PNPMF).

Paralelamente, como instituição que desempenha papel essencial na interface dos sistemas de Ciência e Tecnologia e Saúde, a Fundação Oswaldo Cruz (Fiocruz) vem participando da gestão da Política e do Programa Nacional de Plantas Medicinais e Fitoterápicos, em cooperação com a Secretaria de Ciência, Tecnologia e Insumos Estratégicos do Ministério da Saúde, contribuindo para a exploração sustentável da biodiversidade, por meio de ações implementadas por vários ministérios, em parceria com instituições da sociedade civil, estados e municípios (Relatório Fiocruz, 2012). Todavia, neste trabalho de pesquisa, enfocaremos o papel estratégico da Fiocruz na implementação da décima segunda diretriz da PNPMF (s. p.), que estabelece a necessidade de "fortalecer e aperfeiçoar os mecanismos governamentais de proteção da propriedade intelectual na área de plantas medicinais e fitoterápicos", desde o uso caseiro e comunitário ao desenvolvimento da pesquisa científica e fabricação de medicamentos industrializados.

No Brasil, no âmbito da propriedade intelectual, a Lei n. ${ }^{\circ} 9.279$ de 14 de maio de 1996, Lei da Propriedade Industrial (LPI), prevê a figura jurídica da Indicação Geográfica (IG), instrumento que apresenta potencial para proteger os aspectos como a qualidade de produtos gerados em determinadas regiões, incluindo o saber fazer tradicional, a forma de produção, a qualidade do clima e do solo. Portanto, apresenta um diferencial importante sobre os demais produtos pelo valor agregado, seja pelas condições do meio ambiente, seja pela reputação da produção.

Nessa perspectiva, observa-se que, no contexto brasileiro, a forma de plantio e de manejo das espécies vegetais comumente desenvolvidas pelas populações locais ou tradicionais aliadas às condições ambientais influenciam diretamente nas características do princípio ativo das plantas. 
Por essa razão, é sugerida a possibilidade de utilizar a figura jurídica da Indicação Geográfica (IG) como ferramenta coletiva de valorização de território e proteção de comunidades locais, tendo como fator estratégico a promoção da forma tradicional e local de desenvolvimento da produção, valorização dos produtos, preservação da biodiversidade e do conhecimento, e possibilita, assim, a sustentabilidade social e econômica dos produtores locais.

\section{A Indicaçăo Geográfica}

A propriedade intelectual no mundo obteve extraordinária importância a partir de meados do final do século XX, principalmente com a criação da Organização Mundial da Propriedade Intelectual (OMPI), em 1967, com o surgimento da Organização Mundial do Comércio (OMC), em 1995, em substituição ao Acordo Geral de Tarifas e Comércio (GATT), e pela celebração de Acordos Internacionais de grande relevância. Abrangem os direitos vinculados à capacidade criativa humana e as criações intelectuais, além de serem imprescindíveis ao crescimento econômico das nações.

A Convenção da Organização Mundial da Propriedade Intelectual (OMPI, 1967, artigo 2..$^{\circ}$ ) define a Propriedade Intelectual como:

A soma dos direitos relativos às obras literárias, artísticas e científicas, às interpretações dos artistas intérpretes e às execuções dos artistas executantes, aos fonogramas e às emissões de radiodifusão, às invenções em todos os domínios da atividade humana, às descobertas científicas, aos desenhos e modelos industriais, às marcas industriais, comerciais e de serviço, bem como às firmas comerciais e denominações comerciais, à proteção contra a concorrência desleal e todos os outros direitos inerentes à atividade intelectual nos domínios industrial, científico, literário e artístico.

No Brasil, a Constituição Federal de 1988 (Brasil, 1988) inovou ao assegurar garantia constitucional aos direitos de propriedade intelectual e vinculá-los à categoria de direitos fundamentais, como prevê o artigo 5. ${ }^{\circ}$ e incisos XXVII e XXIX: 
Artigo 5.: Todos são iguais perante a lei, sem distinção de qualquer natureza, garantindo-se aos brasileiros e aos estrangeiros residentes no País a inviolabilidade do direito à vida, à liberdade, à igualdade, à segurança e à propriedade, nos termos seguintes: Inciso XXVII - Aos autores pertence o direito exclusivo de utilização, publicação ou reprodução de suas obras, transmissível aos herdeiros pelo tempo que a lei deixar.

Inciso XXIX - A lei assegurará aos autores de inventos industriais privilégio temporário para sua utilização, bem como proteção às criações industriais, à propriedade das marcas, aos nomes de empresas e outros signos distintivos, tendo em vista o interesse social e o desenvolvimento tecnológico e econômico do país.

A propriedade intelectual no Brasil é regida pela seguinte legislação: Lei n. ${ }^{\circ}$ 9.279/1996 - Lei da Propriedade Industrial (LPI); Lei n. ${ }^{\circ}$ 9.610/1998 - Lei de Direitos do Autor; Lei n. ${ }^{\circ}$ 9.456/1997 - Lei da Proteção de Cultivares; e Lei n. ${ }^{\circ}$ 9.609/1998 - Lei da Proteção da Propriedade Intelectual de Programas de Computador (Lei de Software).

Destaca-se a Propriedade Industrial como um ramo da Propriedade Intelectual, que trata das criações intelectuais voltadas para as atividades da indústria, comércio e prestação de serviços, e engloba a proteção das invenções (patente de invenção e modelo de utilidade), desenhos industriais, marcas, indicações geográficas, além da repressão da concorrência desleal.

No âmbito nacional, o Sistema de Propriedade Industrial é constituído pela Lei da Propriedade Industrial, pela Convenção da União de Paris (CUP) e por alguns Tratados Internacionais - Acordo sobre os Aspectos dos Direitos de Propriedade Intelectual Relacionados ao Comércio (TRIPS), Tratado de Cooperação em Matéria de Patentes (PCT) -, assim como pelos Atos Normativos e Resoluções do Instituto da Propriedade Industrial (INPI).

O INPI é o órgão responsável pela aplicação da legislação referente à Propriedade Industrial e tem como principal função: analisar e julgar os pedidos de patentes de invenção, modelos de utilidade, desenhos industriais, marcas, aprovar e averbar os contratos de transferência a de tecnologia e pelo reconhecimento das Indicações Geográficas.

A Indicação Geográfica (IG) é considerada um ativo intangível no âmbito da propriedade industrial e se constitui como uma ferramenta coleti- 
va de proteção e valorização de produtos tradicionais associados a determinados territórios. Não obstante visa promover e garantir a qualidade de produtos de origem geográfica de renome comprovado, ressaltando o saber fazer tradicional, a forma de produção e costumes, além de fatores ambientais como a qualidade do clima e do solo etc.

Observa-se que os produtos desenvolvidos nas regiões protegidas por Indicações Geográficas (IG) potencialmente adquirem um diferencial importante sobre os demais pelo valor que agregam, seja pela reputação da produção, seja pelas condições do meio ambiente.

Historicamente, algumas regiões no mundo e os seus produtos especiais, foram desenvolvendo grande prestígio e conquistaram aumento de preços. Em compensação, acabou gerando falsificações e má utilização dos nomes das regiões. A partir deste cenário, a necessidade de garantir e proteger a qualidade e a origem dos produtos gerou legislações e acordos comerciais entre os países, com vistas à proteção contra a concorrência desleal e as falsas indicações de procedência.

Datada de 1883, a Convenção da União de Paris (CUP) foi o marco inicial da Propriedade Industrial e foi considerada um dos mais importantes diplomas internacionais sobre a matéria, estabelecendo padrões mínimos de proteção que foram adotados pelos países signatários. Foi o primeiro acordo internacional de proteção às Indicações de Procedência. O Brasil sempre esteve ligado à discussão sobre Propriedade Intelectual em nível internacional, sendo um dos onze países a assinar a CUP. A Convenção já sofreu algumas revisões desde a sua assinatura.

Em 1891, o Acordo de Madrid reprime as falsas indicações de procedência e o uso de expressões que levassem o consumidor ao erro, estabelecendo no seu artigo 1. :

Todo produto que trouxer indicação falsa de sua procedência, na qual direta ou indiretamente se mencionar como país ou lugar de origem um dos países contratantes ou algum lugar em qualquer deles situado, será apreendido no ato da importação em cada um dos referidos países.

No entanto, como os mecanismos de proteção às Indicações Geográficas previstos nos acordos anteriores ainda não se mostraram suficientes, em 1958, foi assinado o Acordo de Lisboa voltado especificamente para a 
proteção das denominações de origem, contudo sem a adesão do Brasil. $\mathrm{O}$ acordo previu que uma vez registrada a denominação de origem, esta também deveria ser reconhecida pelos países signatários do acordo. Foi o primeiro acordo propondo um registro internacional, e, justamente por este caráter restritivo, obteve pouca adesão. Na verdade, o acordo interessava basicamente aos países da Europa pelo grande número de registros de IGs.

Em 1994, surge o Acordo sobre os Aspectos dos Direitos de Propriedade Intelectual Relacionados ao Comércio (TRIPS). Este tratado fez parte do Acordo que constituiu a Organização Mundial do Comércio (OMC), que estabeleceu padrões mínimos de proteção da Propriedade Intelectual no mundo, além de relacionar questões de propriedade industrial ao comércio. No que concerne às Indicações Geográficas estabeleceu o seguinte:

Para os fins deste Acordo, entende-se indicações geográficas indicações que identifiquem um produto como originário do território de um Membro, ou região ou localidade deste território, quando determinada qualidade, reputação ou outra característica do produto seja essencialmente atribuída à sua origem geográfica (TRIPS, 1994, artigo 22, parágrafo $1 .^{\circ}$ ).

O Brasil foi um dos primeiros a assinar esse acordo que foi implementado no país por meio da Lei 9.279/1996, a Lei de Propriedade Industrial (LPI), que regula as Indicações Geográficas (IG). Contudo, a Instrução Normativa n. ${ }^{\circ} 25$ de 21 de agosto de 2013, do Instituto Nacional da Propriedade Industrial - INPI, estabelece as condições para o registro destes instrumentos.

A legislação nacional apresenta duas espécies de Indicações Geográficas, cada qual correspondendo a um instrumento jurídico específico, conforme rezam os artigos 176, 177 e 178, da Lei n. ${ }^{\circ}$ 9.279/1996:

Art. 176. Constitui indicação geográfica a indicação de procedência ou a denominação de origem.

Art. 177. Considera-se indicação de procedência o nome geográfico de país, cidade, região ou localidade de seu território, que se tenha tornado conhecido como centro de extração, produção ou fabri- 
cação de determinado produto ou de prestação de determinado serviço.

Art. 178. Considera-se denominação de origem o nome geográfico de país, cidade, região ou localidade de seu território, que designe produto ou serviço cujas qualidades ou características se devam exclusiva ou essencialmente ao meio geográfico, incluídos fatores naturais e humanos (Brasil, 1996).

Diferentemente de outros ativos intangíveis previstos na LPI, a Indicação Geográfica, quando concedida, vigora por tempo indeterminado e tem cunho declaratório. É inalienável, indivisível, não pode ser licenciada e deve estar vinculada a uma área geográfica.

\section{As Indicaçồes Geográficas no desenvolvimento econômico e social}

Consideradas sinais distintivos coletivos, as Indicações Geográficas estão vinculadas ao interesse social e ao desenvolvimento tecnológico e econômico, assim como todos os direitos de propriedade intelectual. Para Locatelli (2009), no contexto dos direitos relativos à propriedade intelectual, as Indicações Geográficas são capazes de fomentar a economia de um país pelo fato de diferenciar os produtos ou serviços pela sua origem.

As Indicações Geográficas são ferramentas coletivas de proteção e promoção de produtos com valor agregado advindos de suas heranças histórico-culturais. Este sistema de proteção intelectual possibilita que as regiões promovam seus produtos com direito reservado aos produtores da região de abrangência. Conforme Ascensão (2005), as Indicações Geográficas diferenciam-se de outros direitos industriais não por se referirem a um sujeito ou sujeitos determinados, mas a um conjunto de pessoas geograficamente delimitado.

O conceito de Indicação Geográfica vem sendo desenvolvido ao longo do tempo a partir da constatação de que alguns produtos de determinados lugares apresentavam qualidades especiais atribuídas à sua procedência, à sua origem geográfica. Os produtos apresentavam um diferencial a partir de características como o modo de fazer tradicional, o solo, o clima, tudo relacionado as regiões de origem. 
Segundo Tonietto (2003, pp. 126-7):

[...] as indicações geográficas possibilitam a valorização e a proteção de produtos cujas qualidades e características são fruto dos fatores naturais (aqueles sobre os quais o homem não pode ter influência direta: latitude, altitude; formação geológica, declividade, textura, estrutura e composição do solo; clima, chuvas, umidade do ar, temperaturas, insolação, ventos; flora natural, entre outros) e dos fatores humanos (sobre os quais o homem tem influência direta e que também são determinantes da qualidade e características dos produtos e que podem ser biológicos, agronômicos ou agroindustriais - exemplo no caso de vinho: porta-enxertos e variedades recomendadas, espaçamento, sistema de vinificação e envelhecimento, entre outros).

Outro aspecto importante característico do reconhecimento de uma IG é possibilitar aos produtores de uma região pouco desenvolvida competirem de forma quase igualitária com grandes empresas, tendo como grande diferencial o valor agregado ao seu produto pela forma natural e artesanal de produção ou características climáticas da região.

De acordo com Gonçalves (2008, p. 69):

[...] as indicações geográficas cumprem um papel essencial de diferenciação dos produtos no mercado. A indicação geográfica goza de estima junto ao público consumidor, permitindo identificar regiões e localidades que possuem produtos e serviços com características e qualidades diferenciadas. O consumo de produtos e serviços identificados como indicação geográfica reflete na economia, e no seu crescimento, da determinada região ou localidade reconhecida.

Kakuta (2006) afirma que as Indicações Geográficas são extremamente relevantes em regiões com baixo volume de produção, pois podem ajudar a manter e consagrar a forma tradicional de desenvolvimento da produção, além de ser uma ferramenta de preservação da biodiversidade, do conhecimento tradicional e dos recursos naturais da região. Nesse contexto, ainda podemos considerar as contribuições para a economia e 
o dinamismo das regiões, que proporcionam a valorização das propriedades rurais e estimulam o surgimento de novas empresas, aumentando as ofertas de empregos e serviços, como turismo e a gastronomia local, além de - e principalmente - diminuir o êxodo rural.

Conforme Gonçalves (2008, p. 69):

É inegável que a economia de um país não se sinta beneficiada se possuir produtos designados por indicações geográficas, visto que estas agregam valor ao produto. O interesse econômico do país corre em paralelo com o particular das empresas estabelecidas na localidade ou região.

O desenvolvimento tecnológico tem possibilitado a algumas regiões e produtores, em especial no agronegócio, disputarem mercados mais exigentes, agregando valor a seus produtos com o uso de certificações e indicando a qualidade de sua produção (Kakuta, 2006). As Indicações Geográficas representam um mecanismo que permite diferenciar os produtos de acordo com a região onde eles são produzidos, colocando selos, autorizados pelo Instituto Nacional da Propriedade Industrial - INPI.

De acordo com Santos (2002):

O que há num determinado lugar é a operação simultânea de várias técnicas, por exemplo, técnicas agrícolas, industriais, de transporte, comércio ou marketing, técnicas que são diferentes para um mesmo produto, segundo as respectivas formas de produção. Essas técnicas particulares, essas 'técnicas industriais', são manejadas por grupos sociais portadores de técnicas socioculturais diversas e se dão sobre um território que, ele próprio, em sua constituição material, é diverso, do ponto de vista técnico. São todas essas técnicas, incluindo as técnicas da vida, que nos dão a estrutura de um lugar.

O Brasil com seu vasto território, ecossistemas, diversidade cultural e conhecimentos tradicionais tem como fator estratégico e relevante ao desenvolvimento econômico e social do país a utilização da indicação Geográfica como proteção ao seu patrimônio nacional. Entendendo que 
desta forma será possível atribuir originalidade à produção brasileira, do saber fazer com produtos diferenciados, qualificados e certificados pela sua origem, estimulando a competitividade do mercado interno além de possibilitar a participação do país no mercado internacional (Tonietto, 2003).

Os pedidos de registro de indicação geográfica no Brasil são 92, até julho de 2014 considerando-se nacionais e estrangeiros, muito poucos, frente ao potencial do país, o que denota a necessidade do estabelecimento de políticas públicas de incentivo ao desenvolvimento deste bem imaterial, integrando governo, produtores e as instituições representativas dos setores produtivos. Além da difusão do conceito, é preciso formar competências nesta área do conhecimento e, mais do que nunca, identificar as regiões e produtos e serviços com potencial de proteção por meio deste ativo.

Atualmente foram concedidos 46 registros de Indicações Geográficas pelo INPI, sendo 38 nacionais (trinta Indicações de Procedência - IP e oito Denominações de Origem - DO) e oito estrangeiras (Denominações de Origem - DO).

As 38 Indicações Geográficas brasileiras concedidas vêm aumentando sua "visibilidade" no país, ampliando a atuação no mercado interno de produtos e serviços e, em determinados casos, melhorando a capacidade produtiva para atender mercados internacionais. Esse reconhecimento contribui para proteção de um patrimônio nacional e econômico, garantindo produtos de notoriedade, originalidade e de qualidade aos consumidores e estimulando o crescimento da economia regional.

O quadro 1 mostra as Indicações Geográficas concedidas pelo INPI em ordem cronológica de concessão. 
Quadro 1. Indicaçồes Geográficas registradas no INPI em ordem cronológica

\begin{tabular}{|c|c|c|c|c|}
\hline \multicolumn{5}{|c|}{ INDICAÇÕES GEOGRÁFICAS REGISTRADAS NO INPI } \\
\hline $\begin{array}{l}\text { Região dos Vinhos } \\
\text { Verdes (Portugal) }\end{array}$ & DO & PT & Vinhos & 1999 \\
\hline Cognac (França) & DO & FR & Destilado Vínico & 2000 \\
\hline Vale dos Vinhedos & IP & $\mathrm{BR} / \mathrm{RS}$ & Vinhos e espumantes & 2002 \\
\hline Franciacorta (Itália) & DO & IT & $\begin{array}{c}\text { Vinhos, espumantes e } \\
\text { bebidas alcoólicas }\end{array}$ & 2003 \\
\hline $\begin{array}{l}\text { Região do Cerrado } \\
\text { Mineiro }\end{array}$ & IP & $\mathrm{BR} / \mathrm{MG}$ & Café & 2005 \\
\hline $\begin{array}{c}\text { Pampa Gaúcho } \\
\text { da Campanha } \\
\text { Meridional }\end{array}$ & IP & $\mathrm{BR} / \mathrm{RS}$ & $\begin{array}{l}\text { Carne bovina e deri- } \\
\text { vados }\end{array}$ & 2006 \\
\hline Paraty & IP & $\mathrm{BR} / \mathrm{RJ}$ & $\begin{array}{l}\text { Aguardente tipo ca- } \\
\text { chaça e composta }\end{array}$ & 2007 \\
\hline $\begin{array}{l}\text { San Daniele } \\
\text { (Itália) }\end{array}$ & DO & IT & $\begin{array}{l}\text { Presunto defumado } \\
\text { cru }\end{array}$ & 2009 \\
\hline $\begin{array}{l}\text { Vale do Submédio } \\
\text { S. Francisco }\end{array}$ & IP & $\mathrm{BR} / \mathrm{BA} / \mathrm{PE}$ & $\begin{array}{l}\text { Uvas de mesa e man- } \\
\text { gas }\end{array}$ & 2009 \\
\hline Vale do Sinos & IP & $\mathrm{BR} / \mathrm{RS}$ & Couro acabado & 2009 \\
\hline $\begin{array}{l}\text { Litoral Norte } \\
\text { Gaúcho }\end{array}$ & $\mathrm{DO}$ & $\mathrm{BR} / \mathrm{RS}$ & Arroz & 2010 \\
\hline Pinto Bandeira & IP & $\mathrm{BR} / \mathrm{RS}$ & Vinhos e espumantes & 2010 \\
\hline $\begin{array}{l}\text { Serra da Manti- } \\
\text { queira de Minas } \\
\text { Gerais }\end{array}$ & IP & $\mathrm{BR} / \mathrm{MG}$ & Café & 2011 \\
\hline $\begin{array}{l}\text { Região do Jalapão } \\
\text { do Estado do TO }\end{array}$ & IP & $\mathrm{BR} / \mathrm{TO}$ & $\begin{array}{c}\text { Artesanato em capim } \\
\text { dourado }\end{array}$ & 2011 \\
\hline Goiabeiras & IP & $\mathrm{BR} / \mathrm{ES}$ & $\begin{array}{l}\text { Artesanato em pane- } \\
\text { las de barro }\end{array}$ & 2011 \\
\hline Costa Negra & DO & $\mathrm{BR} / \mathrm{CE}$ & Camarão & 2011 \\
\hline Pelotas & IP & $\mathrm{BR} / \mathrm{RS}$ & $\begin{array}{l}\text { Doces tradicionais e } \\
\text { confeitaria/frutas }\end{array}$ & 2011 \\
\hline
\end{tabular}




\begin{tabular}{|c|c|c|c|c|}
\hline Serro & IP & $\mathrm{BR} / \mathrm{MG}$ & $\begin{array}{c}\text { Queijo Minas artesa- } \\
\text { nal do Serro }\end{array}$ & 2011 \\
\hline $\begin{array}{l}\text { Vales da Uva } \\
\text { Goethe }\end{array}$ & IP & $\mathrm{BR} / \mathrm{SC}$ & Vinhos de uva Goethe & 2012 \\
\hline São João Del-Rei & IP & $\mathrm{BR} / \mathrm{MG}$ & $\begin{array}{c}\text { Peças artesanais em } \\
\text { Estanho }\end{array}$ & 2012 \\
\hline Canastra & IP & $\mathrm{BR} / \mathrm{MG}$ & Queijo canastra & 2012 \\
\hline Franca & IP & $\mathrm{BR} / \mathrm{SP}$ & Calçados & 2012 \\
\hline Porto (Portugal) & DO & PT & $\begin{array}{l}\text { Vinho generoso } \\
\text { (vinho licoroso) }\end{array}$ & 2012 \\
\hline Pedro II & IP & $\mathrm{BR} / \mathrm{PI}$ & $\begin{array}{l}\text { Opalas preciosas e } \\
\text { joias artesanais }\end{array}$ & 2012 \\
\hline $\begin{array}{l}\text { Região Pedra Cari- } \\
\text { jó Rio de Janeiro }\end{array}$ & $\mathrm{DO}$ & $\mathrm{BR} / \mathrm{RJ}$ & $\begin{array}{l}\text { Gnaisse fitado miloní- } \\
\text { tico branco }\end{array}$ & 2012 \\
\hline $\begin{array}{l}\text { Região Pedra Ma- } \\
\text { deira Rio de Janeiro }\end{array}$ & $\mathrm{DO}$ & $\mathrm{BR} / \mathrm{RJ}$ & $\begin{array}{l}\text { Gnaisse fitado } \\
\text { milonítico claro }\end{array}$ & 2012 \\
\hline $\begin{array}{l}\text { Região Pedra Cinza } \\
\text { Rio de Janeiro }\end{array}$ & DO & $\mathrm{BR} / \mathrm{RJ}$ & $\begin{array}{l}\text { Gnaisse fitado } \\
\text { milonítico cinza }\end{array}$ & 2012 \\
\hline $\begin{array}{l}\text { Cachoeiro de } \\
\text { Itapemirim }\end{array}$ & IP & $\mathrm{BR} / \mathrm{ES}$ & Mármore & 2012 \\
\hline Linhares & IP & $\mathrm{BR} / \mathrm{ES}$ & Cacau em amêndoas & 2012 \\
\hline $\begin{array}{l}\text { Manguezais de } \\
\text { Alagoas }\end{array}$ & $\mathrm{DO}$ & $\mathrm{BR} / \mathrm{AL}$ & Própolis vermelha & 2012 \\
\hline Napa Valley (EUA) & DO & US & Vinhos & 2012 \\
\hline Vale dos Vinhedos & DO & $\mathrm{BR} / \mathrm{RS}$ & $\begin{array}{c}\text { Vinhos tinto, branco e } \\
\text { espumante }\end{array}$ & 2012 \\
\hline $\begin{array}{l}\text { Norte Pioneiro do } \\
\text { Paraná }\end{array}$ & IP & $\mathrm{BR} / \mathrm{PR}$ & Café & 2012 \\
\hline Paraíba & IP & $\mathrm{BR} / \mathrm{PB}$ & $\begin{array}{l}\text { Têxteis de algodão } \\
\text { colorido }\end{array}$ & 2012 \\
\hline Região de Salinas & IP & $\mathrm{BR} / \mathrm{MG}$ & $\begin{array}{l}\text { Aguardente de cana } \\
\text { tipo cachaça }\end{array}$ & 2012 \\
\hline Divina Pastora & IP & $\mathrm{BR} / \mathrm{SE}$ & $\begin{array}{c}\text { Renda de agulha } \\
\text { em lacê }\end{array}$ & 2012 \\
\hline
\end{tabular}




\begin{tabular}{|c|c|c|c|c|}
\hline Porto Digital & IP & BR/PE & Serviços de TI & 2012 \\
\hline Altos Montes & IP & BR/RS & Vinhos e espumantes & 2012 \\
\hline $\begin{array}{c}\text { Champagne } \\
\text { (França) }\end{array}$ & DO & FR & Vinhos espumantes & 2012 \\
\hline Roquefort (França) & DO & FR & Queijo & 2013 \\
\hline São Tiago & IP & BR/MG & Biscoito & 2013 \\
\hline Alta Mogiana & IP & BR/SP & Café & 2013 \\
\hline Mossoró & IP & BR/RN & Melão & 2013 \\
\hline Cariri Paraibano & IP & BR/PB & Renda renascença & 2013 \\
\hline Monte Belo & IP & BR/RS & Vinhos e espumantes & 2013 \\
\hline $\begin{array}{c}\text { Região do Cerrado } \\
\text { Mineiro }\end{array}$ & DO & BR/MG & $\begin{array}{c}\text { Café verde em grão } \\
\text { industrializado em } \\
\text { grão ou moído }\end{array}$ & 2013 \\
\hline
\end{tabular}

Fonte: Instituto Nacional da Propriedade Industrial - INPI.

O registro de Indicação Geográfica (IG), no Brasil, principalmente no que se refere ao incentivo de práticas de uso de plantas medicinais e fitoterápicos, poderia gerar benefícios a toda a cadeia produtiva, além da saúde da população.

No contexto internacional, o panorama, no entanto, é outro. Tomando como exemplo a Europa, origem da proteção de IGs no mundo, como resultado de busca na Base DOOR da Comunidade Europeia, foram recuperadas, em julho de 2014, 1.232 IGs registradas, sendo 581 Denominações de Origem protegidas, 605 Indicações de Procedência Protegidas e 46 Especialidades Tradicionais Garantidas.

$\mathrm{Na}$ comunidade europeia, dezesseis regiões são protegidas por Indicações Geográficas que envolvem plantas, o que pode ser observado no quadro 2. Duas delas são da China e Índia. 


\section{Quadro 2. Indicaçôes Geográficas constantes na Base D00R da Comunida- de Europeia}

\begin{tabular}{|c|c|}
\hline \multicolumn{2}{|c|}{ INDICAÇÕES GEOGRÁFICAS - BASE DOOR DA COMUNIDADE EUROPEIA } \\
\hline PLANTAS/FLORES & ÁREA GEOGRÁFICA \\
\hline Óleo de Lavanda & Alpes - França \\
\hline Óleo de Bergamota & Calábria - Itália \\
\hline Camomila Bohemica & Bohemia - República Checa \\
\hline Camomila Hungria & $\begin{array}{l}\text { Szabolcs-Szatmár-Bereg, Borsod-Abaúj-Zemplén, } \\
\text { Heves, Jász-Nagykun-Szolnok, Hajdú-Bihar, Békés, } \\
\text { Csongrád, Bács-Kiskun e Peste - Hungria }\end{array}$ \\
\hline Chá de Darjeeling & Darjeeling - Índia \\
\hline Chá de Longjing & Xihu/Quiantang/Yuizhou - China \\
\hline $\begin{array}{l}\text { Zafferano di San Gimi- } \\
\text { niano }\end{array}$ & San Giminiano - Itália \\
\hline Zafferano L'Aquila & Áquila - Itália \\
\hline Alcaçuz e extrato Calábria & Calábria - Itália \\
\hline Açafrão de Dardena & Sardenha - Itália \\
\hline Azafrán de La Mancha & La Mancha - Espanha \\
\hline Azálea & Gante - Bélgica \\
\hline Cominho & República Checa \\
\hline Lúpulo & $\begin{array}{l}\text { Eriskirch, Friedrichshafen, Hagnau am Bodensee, } \\
\text { Immenstaad am Bodensee, Kressbronn am Bo- } \\
\text { densee, Langenargen, Markdorf, Meckenbeuren, } \\
\text { Neukirch, Oberteuringen e Tettnang, no distrito } \\
\text { do Lago de Constança (Bodenseekreis) - Alemanha }\end{array}$ \\
\hline Lúpulo 2 & $\begin{array}{l}\text { Hallertau abrange os Landkreisen Eichstätt, Frei- } \\
\text { sing, Kehlheim, Landshut, Nürnberger Land e } \\
\text { Pfaffenhofen. - Alemanha }\end{array}$ \\
\hline Lúpulo 3 & Žatecká chmelařská oblast - República Checa \\
\hline
\end{tabular}

Fonte: Base D00R da Comunidade Europeia. 
Não obstante, países emergentes como Índia e China vêm utilizando o ativo intangível das Indicações Geográficas como forma de valorizar e garantir a qualidade original de seus produtos tradicionais (Kakuta, 2006).

Nas últimas décadas, o governo brasileiro vem percebendo a relevância do papel das IGs e do seu potencial para o desenvolvimento econômico e social. Contudo, Santilli (2005) destaca que é fundamental a utilização de instrumentos alinhados a uma política de desenvolvimento territorial, social e humano, considerando a diversidade cultural do país. Segundo o autor:

[...] as Indicações Geográficas poderiam ser instrumentos úteis à diferenciação dos produtos gerados por povos tradicionais no mercado, agregando-lhes valor cultural e ambiental, oferecendo ao consumidor uma marca distintiva de sua tipicidade, beneficiando-se de nichos específicos de mercado (p. 201).

Pode ser, portanto, uma alternativa para a proteção dos direitos do conhecimento tradicional associado, assim como possibilitar aos produtores de regiões pouco desenvolvidas sustentabilidade, tendo como o grande diferencial o valor agregado ao seu produto, seja pelas condições do meio ambiente, seja pela reputação da produção, seja pelo diferencial de comércio justo. ${ }^{2}$

\section{Processo de Reconhecimento e Registro de Indicaçăo Geográfica}

- Organizar os produtores interessados no reconhecimento da Indicação Geográfica em uma instituição representativa;

- Realizar um levantamento histórico-cultural: identificar publicações em jornais, revistas, entrevistas, reportagens, livros e tra-

2 Comércio justo é uma "parceria comercial, baseada em diálogo, transparência e respeito, que busca maior equidade no comércio internacional. Ele contribui para o desenvolvimento sustentável, por meio de melhores condições de troca e garantia dos direitos para produtores e trabalhadores marginalizados". IFAT - International Federation of Alternative Trade. Disponível em: www.ifat.org. 
balhos científicos que comprovem que a região é conhecida pela produção de determinado produto ou serviço;

- Construir o Regulamento de Uso, constando as etapas do processo de produção, essencial para que o produto tenha garantia da origem e de rastreabilidade;

- Institucionalizar um Conselho Regulador que será responsável pela gestão, manutenção e preservação da Indicação Geográfica.

O pedido de registro de Indicação Geográfica deverá ser encaminhado ao Instituto Nacional da Propriedade Industrial - INPI por pessoa jurídica representativa dos produtores (natureza jurídica: associação, fundação ou cooperativa).

O Brasil, graças à sua natureza, congrega uma das maiores vegetações do planeta, aliada a uma sociodiversidade que detém um extraordinário conhecimento sobre a utilização de plantas para benefício da saúde. Por estas razões, tem potencial e vantagem competitiva para atender a um mercado promissor de plantas medicinais e fitoterápicos que cresce tanto no país quanto no resto do mundo.

Com base nesta biodiversidade e tradição no uso de plantas medicinais, tem capacidade para estabelecer um modelo de desenvolvimento próprio na área de saúde, promovendo as diversas práticas e formas de uso das plantas medicinais com segurança e eficácia, desde o uso caseiro e comunitário, ao desenvolvimento de pesquisas científicas e fabricação de medicamentos industrializados. Dessa forma, é um grande desafio melhorar o nosso sistema produtivo para atender a esse novo mercado, adotando práticas agrícolas adequadas no cultivo, no beneficiamento e na armazenagem da produção.

Muito embora as políticas públicas relacionadas ao uso de plantas medicinais tenham sido instituídas e congreguem avanços, como o Programa Nacional de Plantas Medicinais e Fitoterápicos (PNPMF), percebe-se que as regulamentações ambientais e sanitárias ainda não favorecem a participação do pequeno produtor urbano familiar nesse processo.

A prospecção de potencial de IG em determinadas regiões dá subsídios à fundamentação para uma possível defesa que venha a garantir a permanência de agricultores familiares e de sua sustentabilidade econômica e social. Para o estabelecimento de uma IG, a reputação da região 
terá que ser reconhecida pelo órgão competente em nível nacional, no caso o INPI, e, desta forma, deve-se comprovar que a região vem sendo habitada por gerações de agricultores.

Outro aspecto importante que deve ser considerado é a possibilidade da IG gerar mais segurança de sustentabilidade para os agricultores que dependem exclusivamente da agricultura para a subsistência, partindo da premissa que a IG possibilitará a abertura para novos mercados, além do impacto socioeconômico que poderá gerar como resultado o interesse por rotas turísticas.

Recomendamos, como fator estratégico, a utilização da proteção do ativo intangível pela origem geográfica (IG) como ferramenta coletiva de proteção e valorização do território, promoção da forma tradicional de desenvolvimento da produção, preservação da biodiversidade e do conhecimento tradicional, assim como possibilitar aos produtores da região sustentabilidade, tendo como o grande diferencial a reputação dos produtos reconhecida pelos consumidores.

Entende-se que o reconhecimento da Indicação Geográfica poderá:

- Garantir a preservação dos saberes coletivos, além de valorizar e estimular o desenvolvimento dos seus territórios;

- Garantir às populações tradicionais uma maior proteção contra a apropriação injusta de seus saberes;

- Promover a qualificação da cadeia produtiva com a introdução de normas básicas para os procedimentos e o desenvolvimento social das comunidades inseridas no entorno das áreas de cultivo.

É necessário que os estudos devem ser conduzidos especialmente no que concerne à busca de mais subsídios para a comprovação da reputação de regiões e que se iniciem processos de delimitação das áreas geográficas a serem protegidas por IG com o órgão pertinente, a julgar pelos obstáculos e os desafios para obtenção e manutenção da IG em função das restrições ambientais existentes nestas regiões.

Sugerimos a realização de estudos prospectivos das Indicações Geográficas de plantas medicinais protegidas nas diversas regiões da Europa. Dessa forma, será possível se apropriar de experiências de IGs reconhecidas e suas espécies - a Indicação de Procedência (IP) ou a Denominação de Origem (DO) -, assim como dos processos de instituição e manuten- 
ção para que a decisão seja tomada com subsídios reais nos casos de potenciais IGs no Brasil.

\section{Referências}

BRASIL. Constituição da República Federativa do Brasil. Brasília, 1988.

. "Decreto n. ${ }^{\circ}$ 1.355, de 30 de dezembro de 1994". Acordo sobre aspectos dos direitos de propriedade intelectual relacionados ao comércio. Brasília, 1994.

Presidência da República. "Lei n. 9.279 de 14 de maio de 1996". Diário Oficial da União, Brasília, 1996.

. "Lei n. ${ }^{\circ}$ 9.456, de 25 de abril de 1997”. Institui a Lei de Proteção de Cultivares e dá outras providências. Brasília, 1997. Disponível em: http:// www.planalto.gov.br/ccivil_03/leis/L9456.htm. Acesso em: 14 jul. 2014.

."Lei n. ${ }^{\circ}$ 9.609, de 19 de fevereiro de 1998". Dispõe sobre a proteção da propriedade intelectual de programa de computador, sua comercialização no País, e dá outras providências. Brasília, 1998. Disponível em: http:// www.planalto.gov.br/ccivil_03/leis/19609.htm. Acesso em: 14 jul. 2014.

. "Lei n. 9 9.610, de 19 de fevereiro de 1998". Altera, atualiza e consolida a legislação sobre direitos autorais e dá outras providências. Brasília, 1998. Disponível em: http://www.planalto.gov.br/ccivil_03/leis/19610.htm. Acesso em: 14 jul. 2014.

. "Decreto n. . 2.519, de 16 de março de 1998". Diário Oficial da República Federativa do Brasil, Brasília, 17 mar. 1998.

Ministério da Saúde. "Decreto n. ${ }^{\circ}$ 5.813, de 22 de junho de 2006". Diário Oficial da União. Brasília, 2006. Disponível em: http://portal. saude.gov.br/portal/arquivos/pdf/portariafito.pdf. Acesso em: 14 jul. 2014.

. Ministério da Saúde. "Portaria n. ${ }^{\circ}$ 971, de 03 de maio de 2006". Aprova a Política Nacional de Práticas Integrativas e Complementares no 
SUS. Diário Oficial da União, Brasília, 2006c. Disponível em: http:// portal.saude.gov.br/portal/arquivos/pdf/portariafito.pdf. Acesso em: 14 jul. 2014.

. Ministério do Meio Ambiente. Disponível em: http://www.mma.gov. br/biodiversidade/biodiversidade-brasileira. Acesso em: 25 fev. 2013. . Instituto Nacional da Propriedade Industrial - INPI. "Instrução Normativa n. ${ }^{\circ}$ 25, de 25 de agosto de 2013”. Rio de Janeiro, 2013. Disponível em: http://www.inpi.gov.br/images/docs/instrucao_normativa_25_indicacoes_geograficas[2].pdf. Acesso em: 14 jul. 2014.

FUNDAÇÃO OSWALDO CRUZ. Relatório de Atividades da Fiocruz 20092011. Rio de Janeiro, 2012.

GONÇALVES, M. F. W. Propriedade Industrial e a proteção dos nomes geográficos: Indicações Geográficas, Indicações de Procedência e Denominações de Origem. Curitiba: Juruá, 2008.

KAKUTA, S. M. Indicações Geográficas: guia de resposta. Porto Alegre: SEBRAE/RS, 2006.

LISBOA. "Acordo de Lisboa, de 31 de outubro de 1958”. Relativo à Proteção das denominações de origem e seu registro internacional. Organização mundial da propriedade intelectual, Genebra, 1997.

MADRID. "Acordo de Madrid, de 14 de abril de 1891". Relativo à repressão das indicações de procedência falsas ou enganosas nas mercadorias.

ORGANIZAÇÃO Mundial da Propriedade Intelectual. Denominações de origem e seu registro internacional. Genebra, 1997.

PARIS. Convenção da União de Paris - CUP. Disponível em: http://www. inpi.gov.br/images/stories/CUP.pdf. Acesso em: 14 jul. 2014.

SANTILLI, J. "As Indicações Geográficas e as Territorialidades Específicas das Populações Tradicionais, Povos Indígenas e Quilombolas". In LAGES, V. et al. (orgs.). Valorização de produtos com diferencial de qualidade e identidade: indicações geográficas e certificações para competitividade nos negócios. 1 ed. Brasília: Sebrae, 2005. 
SANTOS, A. S. R. Biodiversidade, bioprospeç̧ão, conhecimento tradicional e o futuro da vida. São Paulo, 2002. Disponível em: http://www.ccuec.unicamp.br/revista/infotec/artigos/silveira.html. Acesso em: 13 maio 2013.

TONIETTO, J. "O papel econômico e o atual tratamento jurídico das indicações geográficas". Anais do 23. Seminário Nacional da Propriedade Intelectual. São Paulo: Associação Brasileira da Propriedade Intelectual, 2003,pp. 126-9. 


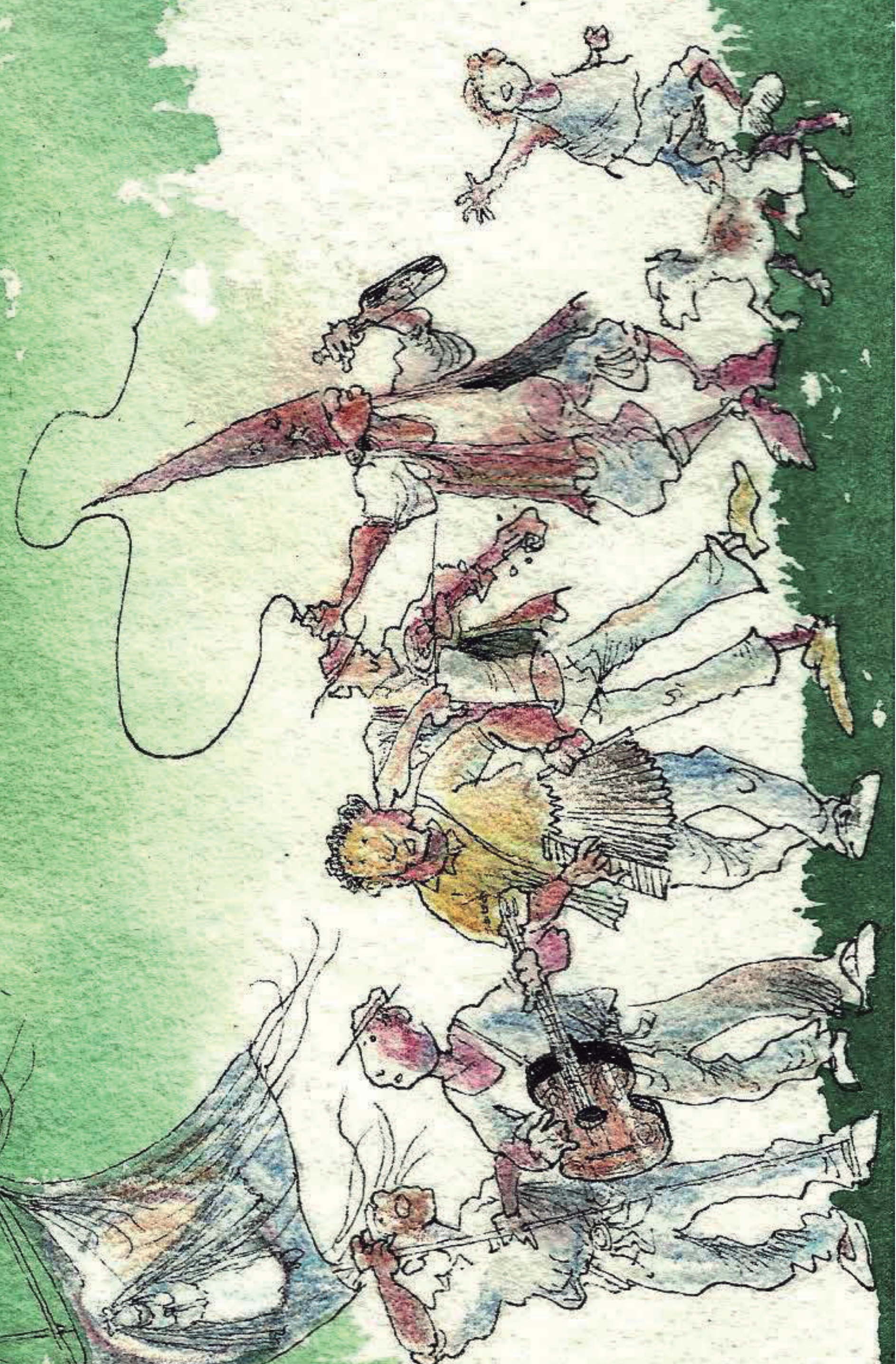




\title{
CAPÍTULO VII
}

\section{Saberes tradicionais e o desafio da multiculturalidade nas instituiçồes de ensino}

\author{
Mariana Martins da Costa Quinteiro \\ Lana Cláudia Fonseca
}

\begin{abstract}
A ciência pode classificar e nomear os órgãos de um sabiá, / mas não pode medir seus encantos./ A ciência não pode calcular quantos cavalos de força/ existem/ nos encantos de um sabiá./ Quem acumula muita informação perde o condão de adivinhar: divinare./ Os sabiás divinam.

Manoel de Barros, Livro sobre Nada
\end{abstract}

\section{Caminhos de entendimento do mundo natural}

É inerente ao homem a busca constante pelo conhecimento do mundo ao seu redor, seja ele físico, social ou espiritual (Cobern, 1996). Como consequência dessa busca, os homens estão sempre atribuindo significados e símbolos ao mundo em que vivem e às suas ações, isto é, estão sempre produzindo cultura, cada qual comportando uma interpretação particular de natureza que constitui um elemento importante da visão de mundo de um povo (Baptista, 2010). Na tentativa constante de compreender a si mesmo e ao mundo que o cerca, a realidade na qual está inserido e da qual é parte fundamental, o ser humano vem criando, incessantemente, formas de conhecer. Este conhecimento seria a maneira mais apropriada de, descrevendo a realidade, apropriar-se dela e, assim, controlar a si mesmo e ao meio.

Em nossa sociedade moderna, a palavra conhecimento tornou-se sinônimo de conhecimento científico. Conhecer passou a ser, desde o surgimento da ciência: descrever a realidade a partir dos pressupostos impostos 
por ela. Entretanto, o conhecimento sempre esteve aliado à história humana, visto que, desde nosso surgimento ancestral, tentamos conhecer para, dentre outros objetivos, entendermos e controlarmos nossa vida. Nesse curso, dividimos as sociedades em grupos que dominam os conhecimentos produzidos cientificamente, e grupos que não conhecem, ou melhor, que dominam um conhecimento não válido, tido como senso comum, ou, quando muito, denominado de folclórico.

Nesse contexto, o conhecimento científico representa "um" dos muitos caminhos para o entendimento do mundo natural, havendo outros meios cognitivos e explicativos, como o das comunidades tradicionais (Southerland, 2000). Endossando essa discussão, diferentes designações do "saber" são encontradas na literatura, como o "tradicional", o "popular" e o "escolar". O saber tradicional pode ser observado como aquele oriundo das comunidades tradicionais - grupos indígenas, quilombolas, caiçaras, ribeirinhos, extrativistas etc. -, percorrendo caminhos por vezes coincidentes e por outros concorrentes com o saber acadêmico, pois os diferentes conhecimentos são fruto de um processo de "circularidade" influenciando e sendo influenciados mutuamente (Morin, 1996).

Diegues e Arruda (2001) definem esse tipo de conhecimento como o "saber" e o "saber-fazer" a respeito do mundo natural e sobrenatural, gerados no âmbito da sociedade não urbana/industrial. Estabelecidas através de informações orais, por meio de "contação de casos", de parcerias em trabalhos conjuntos, na realização de mutirões, cantigas e de tempo de permanência entre membros jovens e mais idosos dessas comunidades, essas formas de conhecimento são consideradas por diversos autores, no campo das etnociências, como estando sob ameaça. Apesar de comportarem uma dinâmica relativa ao próprio mundo natural e não estarem resignadas a serem imutáveis ao longo das gerações, muitos são os desafios para sua permanência no mundo atual.

O saber popular, analogamente, é definido como aquele fruto da produção de significados das camadas populares da sociedade, ou seja, as classes dominadas do ponto de vista econômico e cultural, que inclui práticas sociais cotidianas e a necessidade de desenvolver mecanismos de luta pela sobrevivência (Lopes, 1999).

Chassot (2001) define o saber escolar como aquele que a escola transmite e, para o autor, a própria ação de transmitir já o descaracteriza, pois se estabelece a diferença entre o produzir e o transmitir. A escola defronta-se com 
duro questionamento (que ela geralmente desconhece) quando se diz que a mesma não é produtora do conhecimento, e sim reprodutora ou apenas transmissora do saber, o que pode ser mitigado por sua contextualização.

As formas de apropriação e transmissão desses diferentes modos do "saber" igualmente os caracterizam e distinguem os meios de sua perpetuação ao longo do tempo. Nesse sentido, muitos aspectos são mais óbvios, como as tradições orais e os registros literários, enquanto outros são difíceis até mesmo de serem discutidos, pois são adotados de forma inconsciente, como as posturas corporais. Tassinari (2001) discute que, entre a oralidade e a escrita há um grande número de situações intermediárias nas quais não prevalecem nem a palavra dita nem os signos linguísticos, mas uma articulação entre ambos, de cunho estético. Soma-se a essa discussão o conceito de "tradições iconográficas", em que a memória social é elaborada e transmitida por intermédio de imagens e enunciações rituais, como discute Severi (2009). O autor considera que focalizando o poder da imagem e da gestualidade para a produção de uma memória coletiva, poderemos mais facilmente compreender como as tradições podem ser transmitidas quase sem recurso à palavra.

Nesse âmbito, a preocupação com a não consideração das especificidades culturais e dos saberes populares nas instituições de ensino é um tema que vem sendo alvo de atenção. Charlot (2000) cita diversos exemplos de reivindicações de consideração da cultura local no ensino formal por todo o mundo, incluindo o Brasil, onde se desenvolve um forte movimento pelo reconhecimento das raízes africanas e indígenas da cultura brasileira. Nessa situação, afirma o direito de cada um ser educado em sua cultura. Por um lado, trata-se de uma afirmação de princípio, a do direito de cada um à diferença cultural e a uma identidade enraizada em suas origens. Por outro, uma exigência de eficácia, já que uma educação que não leva em conta as raízes do educando a mergulha em contradições que podem acarretar o fracasso do processo de aprendizagem.

\section{A construçăo do saber ambiental}

A atual demanda da sociedade no campo do ensino se dá por aprendizagens contínuas e complexas, que exigem um redimensionamento do campo educativo, no sentido de interagir mais com as realidades locais 
e globais e reproduzir menos os modelos simplificadores e simplistas vigentes. Novas propostas de currículos devem propor espaços dedicados ao estudo de diversos subsistemas da realidade socioambiental. Como propõe Luzzi (2003), devemos internalizar a dimensão ambiental através de um "diálogo de saberes", por meio do contato entre o conhecimento popular e o conhecimento científico, que produzirá um conhecimento, fruto da circularidade de ambos, impregnado da dialogicidade, fundamental ao processo pedagógico.

Como um reflexo da sociedade atual em que nos encontramos, o conhecimento produzido encontra-se pouco articulado com situações cotidianas que vivenciamos. A fragmentação do saber, representada pelas especializações do conhecimento, aprofundou a compreensão das partes. Contudo, o ambiente é também uma unidade que precisa ser compreendida de forma integral e é através de um conhecimento transdisciplinar que poderemos assimilar plenamente o equilíbrio dinâmico do ambiente (Guimarães, 1995).

Nesse contexto, a educação ambiental vem sendo definida como inter e transdisciplinar, orientada para a resolução de problemas locais, participativa e comunitária, criativa e ativa. É definida, muitas vezes, como transformadora de valores e atitudes através da construção de novos hábitos e conhecimentos, criadora de uma nova ética, sensibilizadora e conscientizadora para relações integradas ser humano/sociedade/natureza objetivando o equilíbrio local e global, como forma de obtenção da melhoria da qualidade de todos os níveis de vida.

Assim, a sociedade deposita sobre as instituições de ensino e pesquisa a esperança de que sejam vanguarda do desenvolvimento, procurando em suas produções a sinalização de rumos, o sensoriamento de tendências e das oportunidades (Demo, 1993). Realizar investigações que atendam aos interesses e demandas da sociedade é uma questão que deveria ser intrínseca aos currículos educacionais. Para esse autor, pesquisa é questão de atitude processual cotidiana, devendo haver o encontro propício da qualidade formal e política, tornando o conhecimento acadêmico mais educativo, científico e menos alienado. A legitimidade retórica das instituições de ensino está em que se concebem a si mesmas como agentes que internalizam os problemas sociais e lhes oferecem soluções no campo do conhecimento e da formação de agentes de transformação social ou de serviço à sociedade (Riojas, 2003). 
Dessa forma, Luzzi (2003) sugere que deveríamos começar a sugerir esboços com respeito a nossas perguntas iniciais: que necessidades de valores, destrezas, conhecimentos e habilidades têm a humanidade para sobreviver e desenvolver-se? Quais deveriam ser, nesse sentido, os interesses que constituem o nosso saber ambiental? Que recorte do saber existente permite superar o fracionamento da informação? As respostas provisórias a essas perguntas, segundo o autor, nos revelaram as estruturas curriculares possíveis de se implementar, longe dos currículos estruturados em disciplinas ou em áreas fracionadas por sua vez em disciplinas; perto da realidade, trabalhando sobre os fenômenos problemáticos e as potencialidades ambientais regionais e locais, porém sem descuidar das relações entre os seus diversos subsistemas.

Assim, poderemos construir espaços escolares mais orgânicos em que os diversos conhecimentos sejam considerados válidos e utilizados como matéria-prima no processo ensino-aprendizagem.

\section{Os espaços multiculturais}

Os espaços das salas de aula não são uniformes do ponto de vista cultural; isto é, não apenas o saber científico, representado pelos professores, encontra-se presente nessa ocasião. Ao contrário, nelas transitam culturas outras, representadas pelos estudantes, como a de sociedades tradicionais (Cobern, 1996), devendo os professores estar atentos às diversas concepções prévias dos estudantes, ou seja, aos conhecimentos populares que circulam nas salas de aula, para que possam direcionar as suas aulas às necessidades individuais e coletivas, nas sociedades e comunidades onde vivem. Nisso consiste a visão das salas de aula como espaços multiculturais, fundamentais para se superar possíveis dificuldades na comunicação, materializando um espaço dialógico, onde os conhecimentos dos alunos e dos grupos aos quais representam, embora diferentes das concepções científicas, sejam reconhecidos e valorizados. Especialmente no caso daqueles estudantes provenientes de meios culturais nos quais a ciência não faz parte de seu cotidiano, como os estudantes oriundos de comunidades tradicionais (Baptista, 2010), o diálogo entre esses conhecimentos se torna fundamental. 
O que pode ser observado nos espaços formais de educação é a substituição dos saberes tradicionais pelos científicos, e não a consideração daquele ou o diálogo de ambos, muitas vezes, gerando conflitos de conceitos que resultam ora em diminuição e desvalorização de sua identidade, ora em não validação e aplicação dos conhecimentos acadêmicos em seu cotidiano. Muitos conteúdos explicativos só fazem sentido e podem ser compreendidos nas especificidades históricas e culturais em que são gerados. Sua desvalorização no interior dos espaços escolares se torna um dos impedimentos dos processos de ensino-aprendizagem.

Mesmo havendo tentativas de valorização da diversidade cultural nas escolas por parte das políticas públicas da educação brasileira, é lamentável o fato de que as realidades das escolas para as sociedades tradicionais ainda insistam na transmissão dos conhecimentos científicos como os únicos válidos (Baptista, 2010). Não se busca aqui alguma forma de hierarquização ou de priorização de um tipo de saber, mas a ampliação de modos de se observar o mundo e a coletividade, valorizando caracterizações culturais específicas.

A discussão ainda se complexifica, pois, mesmo dentro de uma determinada comunidade, o conhecimento não é homogêneo, havendo aqueles específicos aos homens, às mulheres e às diferentes categorias com as quais esses atores sociais se reconhecem, como "parteiras", "benzedeiros", "erveiros", "mateiros", "tropeiros", "carvoeiros", entre outros. Soma-se a importância da família na transmissão desse conhecimento, onde as novas gerações aprendem com as mais antigas, tanto em espaços informais quanto em "formais", como a roça, a mata, a cozinha, o quintal e na presença de ferramentas específicas como moinhos e monjolos. E, ainda, as particularidades das formas de conhecimento ditas "simbólicas" ou "folclóricas", como as "doenças culturais" (como "quebranto", "vento-virado", "olho-gordo", "espinhela-caída" etc,), as "simpatias" e os personagens "mitológicos", assim designados por não se encontrar na academia uma correspondência imediata à sua existência.

Essa valorização exclusiva da ciência nos espaços escolares acaba resultando na exclusão de outros saberes e impedindo a materialização de processos pedagógicos dialógicos.

A consideração desses conhecimentos tão minuciosos requer uma interpretação e consideração muito detalhada. No caso dos saberes ambientais, por exemplo, cada zona ecológica específica da paisagem, sim- 
bologia e ator social determinado é capaz de oferecer um universo rico de detalhes com o qual o conhecimento acadêmico pode dialogar. Dessa forma, o encontro propício dessas sabedorias, científicas e populares, pode possibilitar o abandono da ideia negativa de ameaça ou perda dos saberes tradicionais, favorecendo a concepção de ressignificação de ideias, proporcionada por esse diálogo e tão valiosa para as constantes mudanças por que passam tanto o ambiente quanto às sociedades. Como afirma Perrelli (2008), a força do conhecimento tradicional reside, justamente, na sua capacidade de se adequar ao mundo atual, além da autonomia que proporciona às populações de onde vem.

Muitas vezes a própria população dita tradicional requer e reivindica o chamado ensino formal, representado pelas instituições de ensino, em diferentes níveis. Essa necessidade é identificada pela vontade de inserção dos seus filhos no processo educacional, procurando uma maior inclusão social. Entretanto, há o contraponto imediato da exclusão do entorno, com o estabelecimento de espaços claramente divididos entre o cotidiano saber da comunidade e o que é abordado nesses locais, considerados como essenciais para a formação dos mais novos; o sentido de comunidade tradicional vai sendo diluído enquanto a escola, símbolo do ensino formal, do "externo", traz a pretensa inclusão cidadã (Paré et al., 2007).

Dessa forma, o saber acadêmico, compulsório pelo viés do ensino formal desde a primeira infância, apresenta o sentido de progresso, de uma lógica racional "necessária" para a formação da visão crítica e para a construção de escolhas conscientes e comprometidas com o desenvolvimento para a liberdade. Essa duvidosa "necessidade", ainda que confirmada por uns mostra-se indubitavelmente insuficiente.

\section{Contribuiçôes do diálogo de saberes}

Como nenhuma outra área do conhecimento humano, as questões ambientais vieram a suscitar nas sociedades, pelas consequências do metabolismo de suas atividades econômicas sobre os sistemas naturais, a discussão das influências de vizinhanças, a avaliação suprafronteiriça de suas atitudes, decisões e procedimentos e a mudança de paradigmas: do paradigma social de uso infinito dos recursos para o novo paradigma do desenvolvimento sustentável (Dias, 2000). 
Apesar da grande polêmica em torno do conceito e das estratégias do que hoje se convencionou denominar "sustentabilidade", é consenso o prisma da multidimensionalidade dessa questão. Definir o ferramental metodológico para viabilizar e implementar a "sustentabilidade" é um grande desafio. A aplicação prática desse conceito passa pela premissa do "manejo sustentável", cujos exemplos são abundantes em grupos humanos estreitamente ligados à natureza.

A acumulação de informações sobre uso de recursos naturais por populações tradicionais tem oferecido aos cientistas modelos de uso sustentável desses mesmos recursos (Albuquerque, 1997; 1999). Pesquisas nessa área podem subsidiar trabalhos sobre usos sustentáveis da biodiversidade através da valorização e do aproveitamento do conhecimento empírico das sociedades humanas, a partir da definição dos sistemas de manejo, incentivando a geração de conhecimentos científicos e tecnológicos voltados para o uso sustentável dos recursos naturais (Fonseca-Kruel e Peixoto, 2004).

O manejo em regime de rendimento sustentável, ou manejo sustentável, é definido por Pavan-Fruehauf (2000) como a forma que trata de estabelecer os parâmetros básicos para definição "do que extrair" (quais espécies), "quanto extrair" (quantidade de biomassa), "quando extrair" (ciclos de colheitas) e "como extrair" (forma de extração do indivíduo e dinâmica da comunidade vegetal). Dessa forma, o manejo sustentável seria um instrumento para a obtenção de métodos necessários à intervenção racional sobre os recursos naturais.

As formas de conhecimento guiadas por critérios de validade locais, fortemente vinculadas aos contextos nos quais foram produzidas, pode constituir peça-chave na observação e intervenção do mundo natural (Quinteiro, 2013). Diversos autores estimulam, assim, o diálogo de saberes nos currículos escolares e acadêmicos. Trata-se de se superar uma visão de mundo etnocêntrica aqui deixada desde a época da colonização, onde a exploração e a espoliação imperavam; de negar toda lógica e conhecimento que não seja o nosso; de pesquisar não "sobre" outras culturas, mas "com" outras culturas (Perrelli, 2008), dando voz a grupos historicamente silenciados. 


\section{Caminhos de um currículo multicultural}

Até que ponto as instituições de ensino formais poderão e deverão remedar a ação pedagógica tradicional é uma das questões mais pertinentes e sobre a qual há muita divergência de opiniões. O consenso reside no fato de que é necessário um redimensionamento da educação no sentido de dialogar com as realidades vigentes e com situações socioambientais locais concretas.

Entretanto, uma vez estando dentro do contexto de responsabilidade social e complexidade das atuais questões ambientais, mais um desafio é enfrentado pelas pesquisas científicas que buscam o retorno de seus resultados: a ausência de metodologias complexas de abordagem dos temas (Quinteiro e Moraes, 2012).

A construção dos currículos nas escolas vem, historicamente, sendo pautada por uma lógica tradicional que se embasa na reprodução de um grupo de conhecimentos que não leva em consideração os saberes oriundos dos grupos aos quais os alunos pertencem. Esse apagamento é fruto de uma hierarquização que acaba por valorizar os conhecimentos científicos em detrimento de conhecimentos tradicionais e populares que circulam nas escolas. Vivemos um momento em que diversas instâncias da sociedade encontram-se mergulhadas em uma crise, dentre as quais podemos destacar a crise socioambiental. A visão de mundo oferecida pela ciência moderna, que se constituiu em bases cartesianas e newtonianas, não consegue mais explicar a realidade, tendo se tornado obsoleta para dar conta de diversos conceitos:

Vivemos hoje num mundo globalmente interligado, no qual os fenômenos biológicos, psicológicos, sociais e ambientais são todos interdependentes. Para descrever esse mundo apropriadamente, necessitamos de uma perspectiva ecológica que a visão de mundo cartesiana não nos oferece. (Capra, 1982, p. 14)

Desde o momento em que a revolução científica substituiu a visão orgânica da natureza pela comparação do mundo com uma máquina, através de Descartes e Newton, a sociedade ocidental passou a se constituir de forma diferente. Podemos perceber que os currículos escolares 
não dão conta dessa visão interligada de ambiente e ainda encontramos, nas escolas, matrizes que vão priorizar uma lógica fragmentada.

Estamos passando por um momento histórico em que é necessário rever as diversas características de nossa sociedade, dentre elas a forma como as instituições de ensino materializam conhecimentos que são necessários ao desenvolvimento de nossa vida, por meio da compreensão de nosso estar no mundo.

Contudo, no que diz respeito aos conhecimentos relacionados às temáticas ambientais que circulam, por exemplo, nos grupos tradicionais, percebemos que a lógica excludente que a ciência implantou em nossa sociedade acaba por priorizar um único caminho de construção de currículos:

[...] a ideia de que o método científico é a única abordagem válida do conhecimento; a concepção do universo como um sistema mecânico composto de unidades materiais elementares; a concepção da vida em sociedade como uma luta competitiva pela existência; e a crença do progresso material ilimitado, a ser alcançado através do conhecimento científico e tecnológico (Capra, 1982, p. 28).

Esse currículo corrobora a hegemonia científica e destaca a ciência como um único caminho para a racionalidade, como nos lembra Boaventura de Sousa Santos (1993, p. 30):

Dos meados do século XIX até hoje a ciência adquiriu total hegemonia no pensamento ocidental e passou a ser socialmente reconhecida pelas virtualidades instrumentais de sua racionalidade, ou seja, pelo desenvolvimento tecnológico que tornou possível. A partir deste momento, o conhecimento científico pôde dispensar a investigação das suas causas como meio de justificação. Socialmente passou a justificar-se, não pelas suas causas, mas pelas suas consequências.

Com isso, o conhecimento científico ganhou uma posição de destaque que passou a divulgá-lo como verdade, como dogma, e passou a negar e a tratar como erro o modo como as classes populares, os grupos tradicio- 
nais, teoricamente não detentores deste conhecimento "oficial", entendem e explicam o mundo.

Nesta ruptura, o conhecimento científico não resgatou o conhecimento popular e estabeleceu "o divórcio entre sujeito e objeto, produtor e produto, em nome da suposta universalidade do outro, do mais 'avançado" (Martins, 1989, p. 114). A ciência ganhou o status de verdade e pareceu esquecer que ela mesma é uma "prática social do conhecimento" (Santos, 1993, p. 11).

Assim torna-se clara a afirmação de Boaventura: "a eficácia social dos fatos individuais ou naturais é determinada pelo sistema de relações sociais e históricas em que se insere" (1996, p. 35). Como podemos pensar em currículos que levem em consideração, em sua construção, a lógica de interpretar a realidade dos grupos populares? Como pensar em alterar o sentido que esses currículos materializam ao fragmentarem os conhecimentos e excluírem de sua construção saberes que não são considerados válidos? Como mudarmos a lógica e pensarmos em currículos que permitam às salas de aula se constituírem em espaços multiculturais, em que todos os conhecimentos que nela circulam sejam considerados válidos e importantes para a constituição da visão de mundo dos sujeitos?

Uma primeira reflexão a ser realizada diz respeito à valorização dos conhecimentos produzidos pelos grupos populares, reorganizando a lógica de que conhecimentos "verdadeiros" devem se embasar na objetividade, na quantificação, no rigor. Os grupos populares produzem conhecimentos que contêm lógicas próprias e sentidos de resistência que, dadas as condições, podem desenvolver-se e transformar-se em armas de luta que produzem formas de ser e estar no mundo.

O currículo gera uma tal relação entre saber e poder que, através de sua linguagem, de seu discurso, exclui aqueles que não se orientam pelos princípios de sua racionalidade formal e instrumental. Assim, limita os que têm como um dos maiores instrumentos de relação com o mundo sua experiência, sua cultura oral, reforçando a visão, até mesmo dos próprios integrantes destas classes de que não "sabem". Como nos diz Freire (1987, p. 50):

De tanto ouvirem de si mesmos que são incapazes, que não sabem nada, que não podem saber, que são enfermos, indolentes, que 
não produzem em virtude de tudo isto, terminam por se convencer de sua 'incapacidade'. Falam de si como os que não sabem e do 'doutor' como o que sabe e a quem devem escutar.

É essa a realidade que temos encontrado nas escolas, a constituição da sala de aula como um espaço que se pauta em um monólogo, que apaga e exclui conhecimentos que não sigam a mesma ordem e lógica dos produzidos pelos grupos hegemonicamente dominantes na sociedade.

Mas, podemos encontrar brechas por meio das quais construiremos possibilidades de materializarmos currículos que resgatem a dialogicidade entre os conhecimentos e assumam a circularidade entre eles. Caminhar no sentido de uma nova relação entre a ciência e saberes populares é promover uma ruptura de paradigmas que pode trazer soluções à atual lógica do mundo em que vivemos e que reduziu "tudo aquilo que é social, humano e biológico à lógica das máquinas artificiais" (Morin, 1996, p. 110). É preciso superarmos esse etnocentrismo científico e fazermos uma relação em que "qualquer deles é feito do outro e ambos fazem algo de novo" (Santos, 1993, p. 43).

Um primeiro movimento nesse sentido é assumirmos que todos os sujeitos produzem conhecimento e, portanto, todas as pessoas constroem lógicas de interpretação da realidade. Pessoas pertencentes às comunidades tradicionais produzem cotidianamente interpretações e visões de ambiente e de como se relacionam com ele.

Ao assumirmos, na construção de currículos, numa perspectiva multicultural, que há diferentes formas de compreender e explicar os fenômenos naturais, ganhamos a possibilidade de estabelecermos o diálogo entre os conhecimentos tradicionais e os científicos. Um exemplo dessa proposição se dá quando se incluem, nos currículos, espaços para a instituição de práticas pedagógicas que utilizem como instrumento didático as histórias de vida dos sujeitos que compõem os grupos tradicionais. Ao registrarmos as memórias e as trajetórias de membros da comunidade, poderemos estabelecer vínculos dialógicos entre os diversos saberes que circulam na comunidade.

Com o estabelecimento desse diálogo com os saberes produzidos pelos sujeitos, podemos construir um movimento de ruptura com a lógica tradicional e rompermos com a ideia de que um conhecimento, para ser aceito como verdadeiro, deve passar por verificação e comprovação. $\mathrm{O}$ 
conhecimento popular ao entrar na sala de aula, a partir do registro das memórias e trajetórias, que pode ser realizado por meio do contato com os diversos grupos que compõem as comunidades tradicionais, estabelece uma outra lógica na construção do currículo, pois "dá voz" a saberes que tradicionalmente não têm espaço nas salas de aula.

O conteúdo programático dos currículos atuais reforça o modelo tradicional de ensino-aprendizagem, pois fragmenta os assuntos, compartimentalizando-os, não fazendo, assim, relação deles com a realidade e o cotidiano dos alunos. Por exemplo, o ensino das questões ambientais é trabalhado linearmente, numa complexificação crescente, porém segmentada, que vai do estudo de fatores bióticos e abióticos até os ecossistemas. Mas não vemos, quase nunca, uma relação entre esses assuntos e a vida dos alunos e até mesmo das nossas, pois se trabalha cada parte do ambiente, isoladamente, sem relação nem contexto.

A interdependência dos elementos que compõem o ambiente é posta de lado, em nome da especialização científica e saberes produzidos por outros grupos que não são, em nenhum momento, mencionados como parte deste conjunto, o qual chamamos ambiente.

Mas, é esta realidade que podemos comprovar no cotidiano dos grupos tradicionais? O sistema de ensino promove mudanças de hábitos, comportamentos e concepções nos indivíduos?

No dia a dia do trabalho com as comunidades tradicionais, vemos que o conhecimento científico é um elemento que passa por suas vidas através de uma espécie de filtro de seus próprios saberes, gerando um outro conhecimento, misto do científico e do popular. Como nos mostram Boaventura de Sousa Santos (1993) e Carlo Ginzburg (1987) há uma circularidade entre o conhecimento científico e o popular, que acaba por gerar uma outra forma de conhecimento. O ideal seria que pudéssemos caminhar no sentido de tornarmos uma prática comum a realização da "dupla ruptura epistemológica”, onde após rompermos com o senso comum (1. r ruptura), rompêssemos com o conhecimento cientificamente elaborado (2. ${ }^{\text {a }}$ ruptura), de forma a organizarmos um conhecimento realmente válido nesses espaços multiculturais.

Nesse sentido, poderemos estabelecer um segundo movimento, em que o conhecimento profundo da realidade das comunidades fosse mais um elemento a compor o currículo. Ao invés de partirmos de uma lógica em que o conhecimento científico é apresentado muitas vezes como ver- 
dade única e absoluta, poderíamos partir dos conhecimentos produzidos pelas comunidades. O que esses grupos sabem e produzem cotidianamente? Esses conhecimentos e concepções podem se constituir em ponto de partida para que estabeleça o conhecimento cientifico escolar e, para isso, seria necessário um movimento de "saída da sala de aula" em que a realidade imediata das comunidades servisse de espaço de investigação para alunos e professores.

Muitas vezes o currículo tradicional limita o movimento de saída da escola e o entorno acaba se tornando um exemplo distante. O reconhecimento das comunidades, vivenciando organicamente seus cotidianos, é um campo fértil para que se entendam a lógica e a construção de conhecimentos. É por meio de uma vivência real que a sala de aula pode ampliar seus limites para além das quatro paredes e constituir-se como um espaço multicultural em que apenas não se fale do entorno, mas que se vivencie a realidade.

Mas, a realidade que vemos é outra: um sistema de ensino que se encontra em acelerado sucateamento e que não leva em consideração o saber popular e o saber dos alunos e alunas, nem dos grupos sociais aos quais pertencem, e reafirmam o discurso científico hegemônico.

Em nossa conjuntura atual, vemos que a escola perdeu o seu papel de transmissora e produtora de conhecimento, de formadora de cidadãos, no amplo sentido da palavra, e dirigiu seus objetivos para a produção de profissionais enquadrados ao mercado:

O que se observa hoje é que o Estado e a Sociedade Civil esperam da escola não a formação do homem-cidadão, plenamente desenvolvido como agente político e produto-produtor da cultura, mas sim a produção do profissional eficiente, o ser economicamente viável. O sistema educacional é diariamente pressionado a adequar o currículo escolar às necessidades do mercado de trabalho [...] hoje, todo ensino é, de certa maneira, profissionalizante, na medida em que para o indivíduo frequentar a escola se justifica apenas como um pré-requisito para a entrada no mercado de trabalho. O conhecimento, a cultura, nada tem valor, se não está diretamente articulado à produção. Tudo que excede a esta necessidade deve ser retirado do currículo escolar (Modesto, 1996, p. 79, grifo nosso). 
Este conhecimento trabalhado na escola reflete a formação cartesiana da sociedade, onde o mundo e suas relações podem ser comparados ao funcionamento de uma máquina, o corpo é separado da mente, a lógica matemática e econômica se sobrepõe à subjetividade dos seres humanos e suas relações. O currículo escolar, de uma maneira geral, trabalha a partir de uma base cartesiana, que leva a um conhecimento fragmentado de tal forma que fica difícil os alunos realizarem conexões entre os mesmos e entre esse conhecimento e a sua vida.

Além disso, o saber desses alunos é ignorado, na maioria das vezes, em nome da validade do conhecimento científico. Esquece-se que "[...] a sabedoria popular [...] representa o uso da razão sob outro sistema muito mais empírico e simbólico, ao mesmo tempo, muito mais sapiencial e dialético que cartesiano e positivista" (Parker, 1996, p. 318).

Um trabalho que permita a construção da sala de aula como um espaço multicultural pode contribuir para que entendamos que "[...] o conhecimento científico não é o reflexo das leis da natureza [...] é necessário, portanto, que toda ciência se interrogue sobre suas estruturas ideológicas e seu enraizamento sócio-cultural” (Morin, 1996, p. 25).

Entendendo o currículo como um artefato social e cultural (Moreira e Silva, 1995), perguntamos: por que a visão de mundo encontrada nas comunidades tradicionais não é levada para dentro da escola como material sócio-cultural a ser trabalhado? Continuamos a tratar o mundo, os seres humanos, a partir de uma visão asséptica, científica, enquanto fora da escola nossos alunos e até nós mesmos encaramos uma vida diferente daquela apresentada nas salas de aula.

As comunidades tradicionais buscam soluções para suas vidas, e as salas de aula precisam se tornar um espaço privilegiado de construção do conhecimento, discussão crítica e, principalmente, formação de cidadania. Um trabalho de investigação que possibilite reflexão teórica e acadêmica e, ao mesmo tempo, assuma o ponto de vista e leve em consideração o saber popular, bem como o conhecimento sistematizado produzido pelos diversos grupos sociais das camadas populares, permitirá a materialização de um currículo mais orgânico.

Levando em consideração que os conhecimentos são diferentes - não hierarquicamente diferentes - devido a suas origens, suas histórias, devemos partir do conhecimento do outro, que, banhado pelo nosso, resultará num conhecimento verdadeiro, possibilitando às comunidades 
tradicionais formas de luta e superação da condição de subalternidade e reprodução digna de suas vidas.

Inferimos que a escola, por ser um elemento presente na vida cotidiana desses grupos, pode possibilitar a construção de espaços dialógicos, pois é possível que nos espaços escolares sejam estruturadas alternativas capazes de contribuir para a organização dos grupos sociais nos diversos espaços nos quais eles transitam e, principalmente, a valorização de seus conhecimentos

Reforçamos que partirmos da afirmação que as comunidades tradicionais produzem conhecimentos que devam ser integrados, pois "[...] a hipótese popular não desarticula causa e efeito [...]” (Peregrino, 1993, p. 79 apud Valla, 1996, p. 181). Podemos estar à frente, com o caminho para entendermos como essas classes "são capazes de produzir conhecimento, são capazes de organizar e sistematizar pensamentos sobre a sociedade" (Valla, 1996, p. 178). Só com o reconhecimento do saber popular, das formas organizadas e sistematizadas com as quais se apresenta o conhecimento produzido pelas camadas populares, poderemos elaborar caminhos que apontem para a construção de uma sociedade mais igualitária e efetivamente democrática.

Em nosso entendimento, um currículo só será realmente válido para as comunidades tradicionais, se delas partir e a elas chegar, pois um conhecimento que não respeite o saber popular, extremamente rico, não pode ter validade. Um currículo multicultural precisa se tornar um espaço de diálogo profundo entre conhecimentos que, ao se mesclarem, construam um conhecimento outro, misto dos anteriores, banhados nas histórias, nas vivências das pessoas.

Uma proposta metodológica e pedagógica que dê atenção às diversas trilhas percorridas pelo conhecimento das comunidades tradicionais e os diversos viéses traçados por este conhecimento, tantas vezes oprimido e impedido de se expressar, é aquela capaz de assumir que vivemos uma "crise de interpretação" (Valla, 1996) e que não basta usarmos apenas metodologias de simplificação do conhecimento científico para atuarmos com as comunidades.

As expressões da cultura popular são a prova de que a visão de mundo das comunidades tradicionais pode oferecer informações sobre a sua produção de conhecimento, sobre as alternativas usadas historicamente para a reprodução de sua vida. Para tal, é necessário fazermos "[...] o esforço 
necessário de compreender as condições e experiências de vida, como também a ação política da população seja acompanhada por uma maior clareza das suas representações e visões de mundo" (Valla, 1996, p. 182).

Nesse sentido, entendemos que a construção de um currículo multicultural, deve se dar cotidianamente, pautada em um diálogo profundo entre os saberes que circulam nas salas de aula. Colocamo-nos contrários à lógica que hierarquiza, apaga e silencia conhecimentos que não são considerados válidos e verdadeiros. Um currículo que faça sentido é aquele em que as comunidades tradicionais se reconheçam e que possam, a partir dele, ampliar sua visão de mundo.

\section{Referências}

ALBUQUERQUE, U. P. "Etnobotânica: uma aproximação teórica e epistemológica”. Revista Brasileira de Farmácia, v. 78, n. 3, pp. 60-4, Rio de Janeiro, 1997.

. "La importância de los estúdios etnobiológicos para estabelecimento de estratégias de manejo y conservación em las florestas tropicales”. Biotemas, v. 12, n. 1, pp. 31-47, 1999.

BAPTISTA, G. C. S. "Importância da demarcação de saberes no ensino de Ciências para sociedades tradicionais". Ciência e educação, v. 16, n. 3, pp. 679-94, 2010.

CAPRA, F. O ponto de mutação. São Paulo: Ed. Cultrix, 1982.

CHARLOT, B. Da relação com o saber: elementos para uma teoria. Porto Alegre: Artes Médicas Sul, 2000.

CHASSOT, A. I. "Outro marco zero para uma história da ciência latino americana”. Química na Nova Escola, v. 7, n. 13, pp. 42-5, 2001.

COBERN, W. W. "Constructivism and non-western Science education research". International Journal of Science Education, v. 4, n. 3, pp. 287303, 1996.

DEMO, P. Desafios modernos da educação. 2 ed. Petrópolis: Vozes, 1993, 120p. 
DIEGUES, A. C. e ARRUDA, R.. S. V. (orgs.). Saberes tradicionais e biodiversidade no Brasil. Brasília: Ministério do Meio Ambiente; São Paulo: USP, 2001.

FREIRE, P. Pedagogia do oprimido. São Paulo: Ed. Paz e Terra, 1993.

GINZBURG, C. O queijo e os vermes: o cotidiano e as idéias de um moleiro perseguido pela Inquisição. São Paulo: Ed. Companhia das Letras, 1987.

GUIMARÃES, M. A dimensão ambiental na educação. Campinas: Papirus, 1995, 107p.

LOPES, A. R. C. Conhecimento escolar: ciência e cotidiano. Rio de Janeiro: EdUERJ, 1999.

LUZZI, D. 'A 'ambientalização' da educação formal: um diálogo aberto na complexidade do campo educativo". In LEFF, E. (coord.). A complexidade ambiental. São Paulo: Cortez, 2003, pp. 178-216.

MARTINS, J. S. Exclusão social e nova desigualdade. São Paulo: Ed. Paulus, 1997.

MOREIRA, A. F. e SILVA, T. T. Currículo, cultura e sociedade. São Paulo: Ed. Cortez, 1995.

MORIN, E. Ciência com consciência. Rio de Janeiro: Ed. Bertrand Brasil, 1996.

PARÉ, M. L. et al. "A educação para quilombolas: experiências de São Miguel dos pretos em restinga seca (RS) e da comunidade Kalunga do Engenho II (GO)”. Cad. Cedes, v. 27, n. 72, pp. 215-32, Campinas, 2007.

PARKER, C. Religião Popular e modernização capitalista: outra lógica na América Latina. Petrópolis: Ed. Vozes, 1996.

PAVAN-FRUEHAUF, S. Plantas medicinais de Mata Atlântica: manejo sustentado e amostragem. São Paulo: Annablume, Fapesp, 2000.

PERRELLI, M.A.S. Conhecimento tradicional e curriculo multicultural, ciência e educação, v. 14, n. 3, pp. 381-96, 2008.

e MORAES, M. G. "Etnociências aplicadas como ferramenta para educação ambiental: resgatando os saberes complexos". p. 59-69. In GUIMARÃES, M. e FONSECA, L. Educação em ciências e educação am- 
biental-caminhos e confluências. 1 ed. Seropédica, RJ: EDUFRRJ, 2012, pp. 59-69.

QUINTEIRO, M. M. C. et al. "Formas de retorno da pesquisa etnobotânica à comunidade no paradigma da complexidade ambiental e educação ambiental”. Revbea, v. 8, n. 1, pp. 91-9, 2013.

RESENDE, D. R. et al. "O saber popular nas aulas de Química: relato de experiência envolvendo a produção do vinho de laranja e sua interpretação no ensino médio". Química Nova na Escola, v. 32, n. 3, pp. 151-60, 2010.

RIOJAS, J. "A complexidade ambiental na universidade”. In LEFF, E. (coord.). A complexidade ambiental. São Paulo: Cortez, 2003, pp. 216-38.

SANTOS, B. S. Introdução a uma ciência pós-moderna. Porto: Ed. Afrontamento, 1993.

SEVERI, C. 2009. "A palavra emprestada ou como falam as imagens". Revista de Antropologia, v. 52, n. 2, pp. 459-506, USP, 2009.

SOUTHERLAND, S. A. "Epistemic universalismand the shortcomings of curricular multicultural science education". Scinece \& Education, v. 9, n. 3, pp. 289-307, 2000.

TASSINARI, A. M. I. "Escola indígena: novos horizontes teóricos, novas fronteiras de educação”. In SILVA, A. L. e FERREIRA, M. K. L. Antropologia, história e educação: a questão indígena e a escola. 2 ed. São Paulo: Global, 2001.

VALLA, V. V. "A crise de interpretação é nossa: procurando compreender a fala das classes subalternas". Revista Educação e Realidade., v. 21, n. 2, pp. 177-90, Porto Alegre, 1996. 


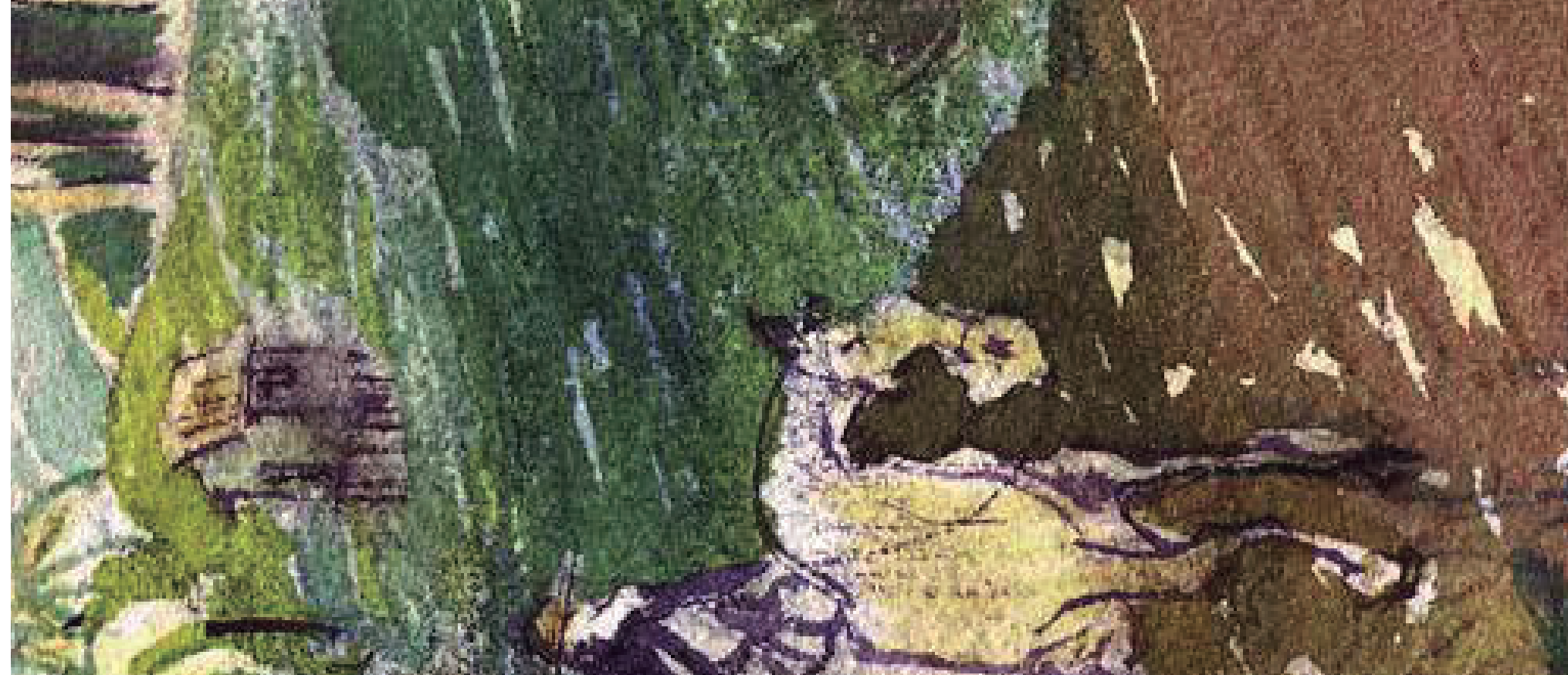

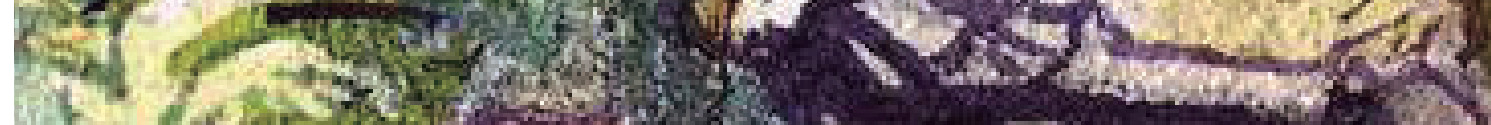

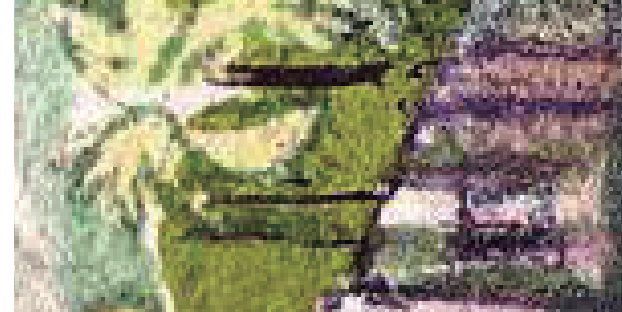

$2 \mathrm{~B}^{2}$
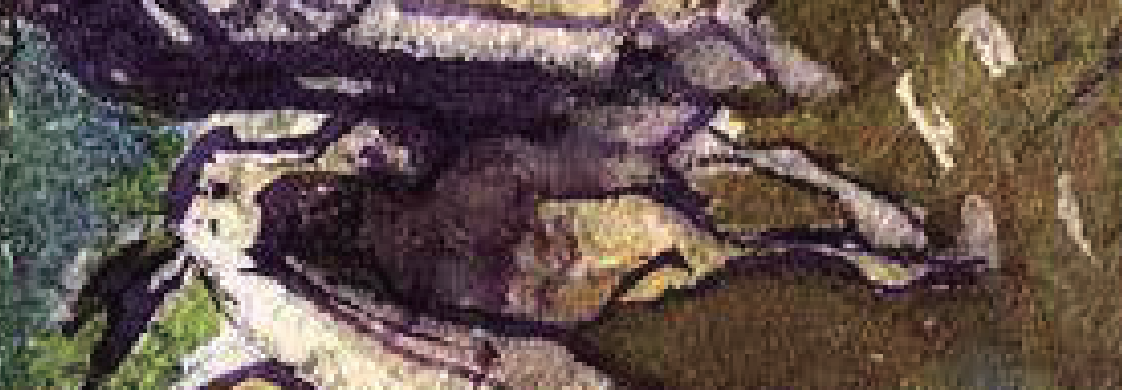

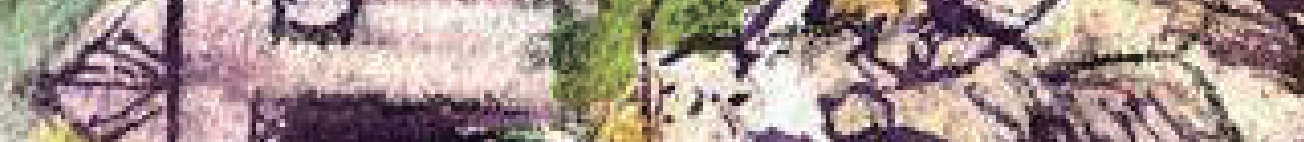

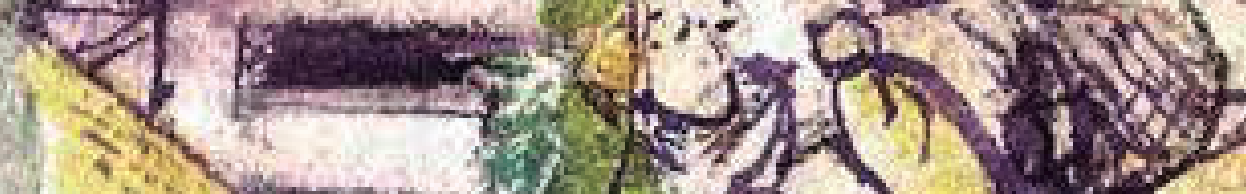
$2473 \mathrm{H}$

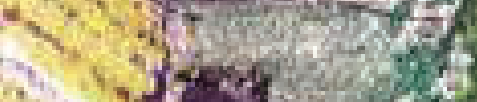

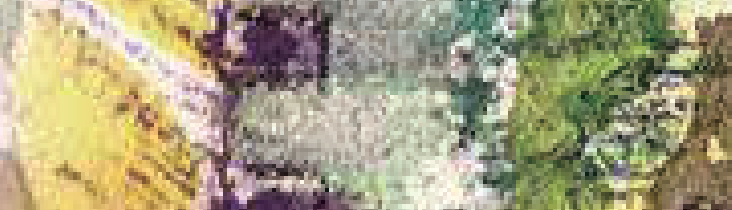

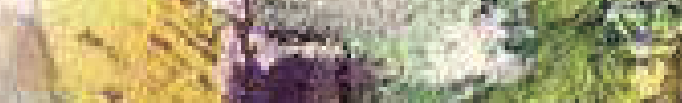
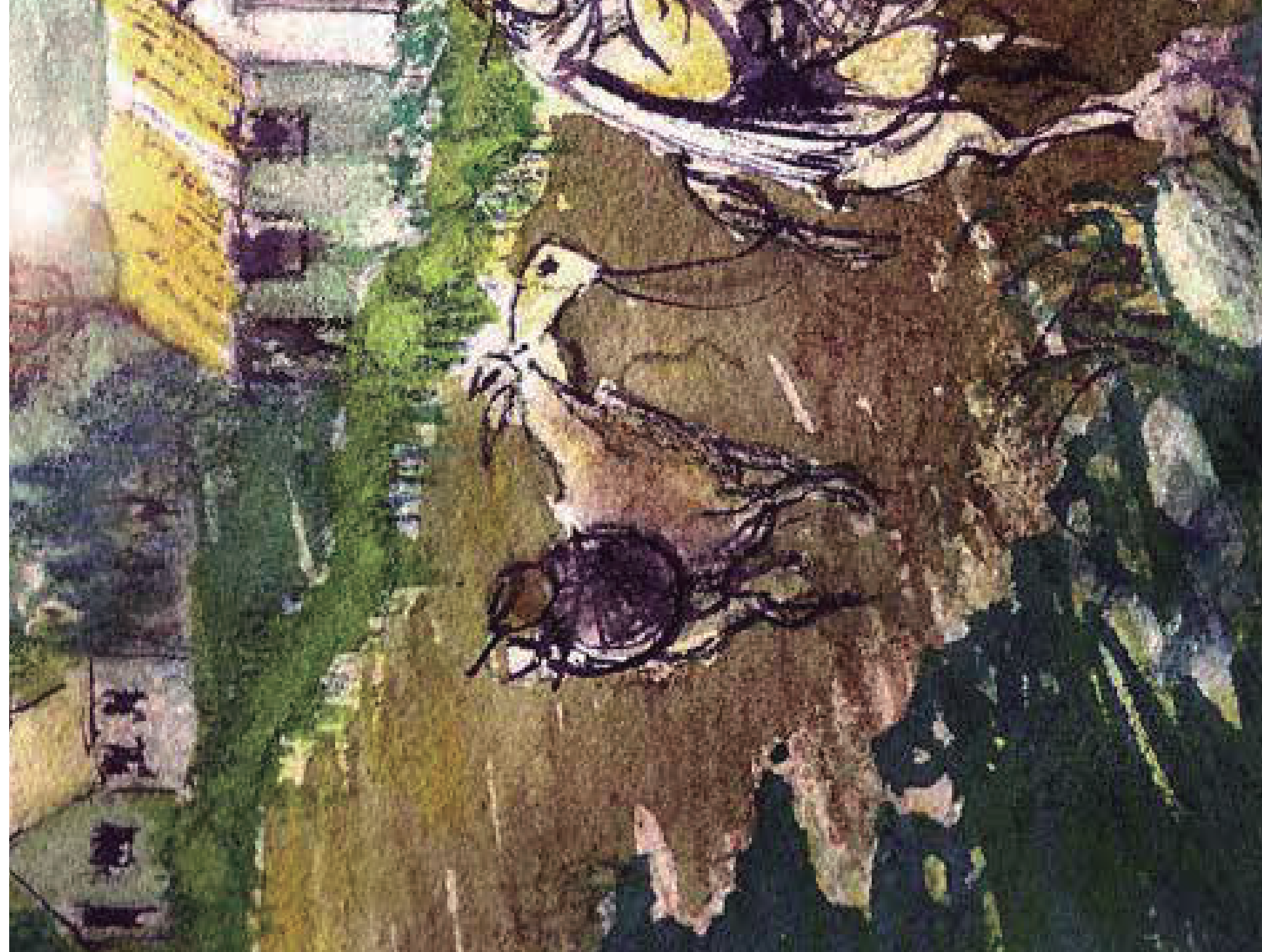

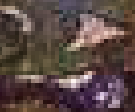

484 


\title{
CAPITULO VIII
}

\section{Relatos históricos e sustentabilidade: um campo de possibilidades fundamentado na etnobotânica}

\author{
Luci de Senna Valle \\ Maria Franco Trindade Medeiros \\ Luiz José Soares Pinto
}

\section{Introduçăo}

Levando-se em conta informações históricas sobre os saberes gerados pelas populações humanas em torno dos recursos vegetais, e, ao considerarmos os aspectos "ambiental" e "temporal", alcançamos a condição que nos permite trilhar os caminhos da interação das pessoas com este mundo vegetal. Através dos norteadores "sociais" e "culturais" as pessoas vão dando sentido àquelas espécies vegetais que compõem o seu ambiente vivencial, por exemplo, selecionando para o cultivo as plantas que integram a sua dieta alimentar, a sua farmacopeia, a sua manifestação religiosa, como também outros domínios culturais intrínsecos à vida humana. Todo esse arcabouço teórico e prático vai se formando, acumulando, transformando e permanece como sendo de domínio daqueles que o geraram, portanto, conhecimento empírico passado de geração a geração chegando até os dias de hoje.

É bem verdade, que desde tempos remotos o homem lançou mão de investigações em áreas bastante ricas e ainda desconhecidas, na atualidade. O complexo de saberes tradicionais ou locais, em constante formação, também interessava àqueles que tinham sua curiosidade aguçada, pelas novas formas de ser e estar, com a qual entravam em contato em determinado instante de suas vidas. Formava-se assim um "conhecimento filtrado" pelo "outro" a partir da apreensão do que era "novo" para si - 
novas relações, opções, construções, novos ambientes, novas condições de sobrevivência, novos tempos.

Situação concreta desta nova apreensão da realidade pode ser constatada no caso dos viajantes europeus em terras brasileiras. Graças ao potencial natural e científico encontrado no Brasil, podemos afirmar que este serviu de fascínio inegável e curiosidade para os viajantes europeus nos séculos XVI a XIX (e ainda nos tempos atuais) como um dos mais preciosos patrimônios nacionais (Martin, 1995; Senna-Valle e Manzali, 2009; Senna-Valle e Medeiros, 2014).

A propósito, pensando-se a questão da temporalidade, poderíamos nos indagar qual seria a razão de voltarmos às questões do passado se o tempo de hoje é cada vez mais breve. A razão é que se percebe cada vez mais ser de fundamental importância, para promoção da sustentabilidade, empenhar-se em pesquisas que entendam o diálogo multidisciplinar como meio pelo qual o resgate de informações - conhecimentos, ou ainda, sabedorias tradicionais e locais - tenham como intuito final apontar caminhos dentro do viés de "sustentabilidade".

No sentido de conjugação de saberes científicos para a construção destas possibilidades de "sustentabilidade", é interessante nos recordarmos de Fitas (1998), que nos revela a importância da interdisciplinaridade entre as ciências da natureza e do ambiente, as ciências sociais e a história. Esse autor reforça a ideia de que áreas distintas do conhecimento contribuem para o relacionamento disciplinar que podem expandir tanto os campos científicos como as metodologias.

Assim, tendo em mente a questão da cronologia, podemos mencionar o campo da etno-história, que tem sido utilizada para dar conta de problemáticas relativas à antropologia e à história. Sugestões podem ser dadas para a etno-história, onde o passado das culturas seria o principal elemento, as fontes de informações seriam as tradições orais ou escritas e a ênfase estaria nas mudanças culturais. Ela constitui-se apenas em um método: trata-se de um campo de estudo que está por se definir e o seu significado varia amplamente de contexto para contexto e de quem o está usando (Carmack, 1979).

Mas, voltando-nos para a ciência etnobiológica, gostaríamos de ressaltar a etnobotânica (etnobiologia) histórica como o campo de possibilidade de diálogo entre a antropologia, a história e a biologia (Medeiros, 2013). Outras áreas do saber também integram as pesquisas em etnobotânica 
histórica. Ainda para esse autor, os critérios de inclusão de determinadas matrizes teóricas e metodológicas dependerá unicamente da perspectiva que se deseja analisar. Nesta linha, em que o principal elemento está focado nas relações das culturas passadas desaparecidas ou viventes com os recursos vegetais, podemos encontrar um meio de refletir a questão da "sustentabilidade" na cultura do presente.

Dentre as fontes de pesquisa mais exploradas, podemos apontar os diferentes tipos de registros históricos, deixados pelos povos e civilizações, ou mesmo como determinado personagem analisava o mundo vegetal em um dado período. Para isto, os manuscritos, relatos históricos e da memória popular, iconografias, esculturas, cerâmicas, música, vestígios de ocupação em sítios arqueológicos e outras que possam contar como viviam os povos em períodos anteriores ao nosso são fontes inesgotáveis de informação, que aos olhos atentos do pesquisador ganham vida e contam a sua história.

\section{Plantas, cronistas, religiosos e naturalistas como protagonis- tas da etnobotânica histórica}

Vamos agora lançar um olhar sobre alguns relatos. Histórias que nos apontarão para uma reflexão em torno da inserção das plantas na constituição da sociedade humana, como também em torno de relatos de cronistas, religiosos e naturalistas que aportaram em terras brasileiras. Por meio destes dados, que têm como cerne a íntima relação que se estabelece entre as pessoas e o universo vegetal ao longo do tempo, vamos tendo diante dos olhos a revelação do que representa a etnobotânica histórica. Essa busca por informações do passado traz elementos culturais que permitem um ato de pensamento no presente, para que se possa alcançar alguma projeção futura nos mais diversos âmbitos.

A seguir, apresentamos relatos de espécies vegetais que consideramos instigantes para o pesquisador no sentido de dar uma sequência a este "aperitivo historiográfico" de cada planta, buscando encontrar, quem sabe, em futuros estudos pessoais, as possibilidades de sustentabilidade para essa herança cultural.

A "mandioca" (Manihot esculenta Crantz) é uma planta tão importante quanto o arroz e o milho nas regiões tropicais em todo o mundo, possuin- 
do grande expressão econômica, social e histórica. No início da colonização, ela se estabeleceu como "pão da terra". Entre os séculos XVI e XIX, a alimentação do brasileiro, de um modo geral, sobretudo nas áreas em que mais se fez sentir a influência indígena, sustentava-se basicamente na cultura e no consumo da mandioca, segundo suas diferentes maneiras. $\mathrm{Na}$ categoria das plantas alimentícias americanas, só abdica lugar à batata e ao milho (Ribeiro, 1983). Admite-se sua provável origem genética ou botânica, como o seu ancestral mais antigo Manihot pusilla Pohl (Albuquerque e Cardoso, 1980). Para a fabricação de farinha, cauim e beijus, os índios ampliavam cultivares de mandioca venenosa (Manihot esculenta Crantz).

Sem a necessidade de solos muito férteis, de técnicas refinadas para a cultura, manipulação e transformação, muitos contribuíram para disseminar e propagar seu uso, sendo sua cultura antiga e tradicional. Já era cultivada pelos indígenas por ocasião do descobrimento do Brasil e, hoje em dia, é explorada tanto em todo território brasileiro quanto em todos os países sul e centro-americanos e nas Antilhas (Albuquerque, 1969).

O "milho" (Zea mays L.), denominado o rei dos cereais, é o terceiro cereal mais importante do mundo, considerado a "planta da civilização" da América por excelência. As culturas de origem americana - milho, batatas, mandioca, abóboras, pimentas e amendoins - fornecem variedade nutricional e alimentar a milhões de pessoas em toda a África, Ásia e Europa, bem como nas Américas (Balick e Cox, 1996). No Novo Mundo, o cereal pré-colombiano característico era o milho (Baker, 1968), que vem sendo plantado desde cerca de 3.000 a 3.500 a.C. nos planaltos mexicanos. Alcançou o Peru 2.000 anos mais tarde, produzindo a mais alta rentabilidade por planta. Os ameríndios cultivaram inúmeras variedades de milho - o preto, o amarelo, o amarelo e preto e o vermelho - e o consomem assado, cozido ou processado, como mingau, farinha e bebida fermentada (Ribeiro, 1983).

Apenas com o uso da enxada e com poucos dias de trabalho ao ano (cerca de cinquenta), o milho garantiu altas densidades populacionais e dispensou um imenso contingente de mão de obra dos afazeres agrícolas, que foi empregado para as monumentais obras arquitetônicas das civilizações pré-colombianas da América (Carneiro, 2003).

O milho e a "batata" (Solanum tuberosum L.) eram, e ainda são, plantas muito presentes na alimentação dos americanos (Baker, 1968). Esta apresenta grande durabilidade e resistência para armazenagem, sendo um recurso alimentício muito versátil nos diferentes modos de preparo desse vegetal. 
Apesar de tais características, a aceitação da batata como alimento na Europa não foi imediata. Quando os primeiros relatos, escritos e ilustrados, chegaram ao continente no século XVI, pensou-se que a batata fosse uma espécie de trufa, o que, ao perceberem que não se tratava disso, causou uma repulsa por parte da nobreza por terem-na considerado um produto mais rústico. A batata teve aceitação primeiro na Irlanda, que lutava por uma maior independência da Inglaterra, e mesmo durante os combates podia manter sua segurança alimentar através desse vegetal, por ser um recurso extraído do subsolo (Cabral, 2016). Assim, desde a sua chegada, na Europa, no final do século XVI, as batatas foram aos poucos ganhando importância na alimentação dos irlandeses, até assumirem o papel de protagonistas na nutrição mundial, sendo uma das principais fontes de calorias, do século XIX.

O "cacau" (Theobroma cacao L.) é a planta do qual se produz o chocolate. O naturalista e médico Carl von Linné (1707-78) denominou a árvore do cacau, que, de acordo com a lenda asteca, significa alimento ou bebida dos deuses (Santos, 1966). Além desse traço cultural de destaque na cultura asteca, devido à sua condição de valorização também na cultura maia, o cacau foi utilizado entre eles como moeda de câmbio em sua sociedade.

A respeito do centro de origem desta espécie, é provável que o cacaueiro seja nativo da Amazônia brasileira, encontrando-se ainda em estado selvagem, na bacia do Orinoco, estendendo o seu habitat até o México, através da América Central. Foi cultivado no hemisfério norte nas terras temperadas da costa do pacífico, antes de Colombo (Ribeiro, 1983).

O franciscano Bernardino de Sahagún fez parte da missão religiosa para o Novo Mundo, mas praticamente deixou de lado sua missão evangelizadora para estudar e registrar, sob o ponto de vista antropológico, as crenças, valores e modo de vida dos nativos americanos. Sua dedicação aos estudos dos povos indígenas locais resultou na obra intitulada História geral das coisas da Nova Espanha, manuscrito que permaneceu obscuro até ser descoberto em uma biblioteca franciscana na cidade de Florença, e, por isso, ele também recebe o nome de Códice Florentino. O códice é composto por doze livros que nos revelam a organização social, as crenças, a economia, a conquista do México por Hernan Cortez, dentre outros aspectos. O Códice Florentino traz descrições e ilustrações do cacau e receitas de uso terapêutico do chocolate, como para diarreia, para diminuir a febre, entre outros usos. Sobre Cortez, este aportou nas Américas em 1505, e a conquis- 
ta do território do México também foi registrada por ele mesmo, nas denominadas Cartas da Relação, escritas entre 1519 e 1526 . Nesses documentos, são descritas as alianças e as batalhas entre os espanhóis e os indígenas até a chegada à capital do império asteca, que atualmente corresponde à Cidade do México. Cortez, ao narrar o contato com o imperador asteca Montezuma, descreve pela primeira vez na literatura ocidental o cacau e o chocolate. Montezuma recebeu Cortez oferecendo-lhe uma bebida servida aos guerreiros e às divindades, conhecida por xocolatl (termo composto por xoco, que significa amargo, e atl, água) (Cabral, 2016).

O "chocolate" preparado à base de cacau era, a princípio, uma infusão em água de uma mistura de cacau, milho e pimenta. Era falado que, ao tempo do governante asteca, Montezuma (ca. 1466-1520), os indivíduos ricos consumiam o cacau puro, adoçado com mel, e com o tempo, os europeus aprimoraram o chocolate, reunindo ao cacau o açúcar de cana, e canela ou baunilha como aromáticos.

No Brasil, o cultivo do cacau ocorreu no século XVII, no Pará. Esse cultivo encontrou terreno fértil para sua expansão, na Bahia, em especial na cidade de Ilhéus, onde continua até hoje. Nessas terras, o cacau se desenvolveu muito bem, o que fez com que von Martius, quando por lá passou em 1819, valorizasse o desenvolvimento dessa árvore (Martius, 1844).

O "maracujá” (família Passifloraceae) é uma fruta por excelência americana, tendo registros de utilização desde o México até a América do Sul. Seus primeiros relatos foram dados por Cienza de Léon, em 1553, comparando-o com a romã (Punica granatum L.), sendo conhecido popularmente em países de língua espanhola como granadilla. Já o termo maracujá tem origem tupi e significa "o alimento que vem em cuia", devido ao formato e disposição das sementes no fruto.

Segundo Cervi (1997), as passifloras foram plantas utilizadas como elemento alegórico para a catequização dos ameríndios, onde um frei espanhol observou elementos da Paixão de Cristo. Daí o nome escolhido por Linnaeus para o gênero Passiflora L., em alusão aos martírios sofridos durante a Paixão de Cristo.

Sendo uma planta destas dada ao Papa Paulo V em 1609, rapidamente a sua procura e a sua representatividade ganharam outras artes, como a pintura, a poesia ("A flor de maracujá", em Cantos meridionais, do poeta Fagundes Varela, 1869) e a música ("A flor de maracujá", de Catulo da Paixão Cearense, interpretado por Rolando Boldrin). 
Porém, na atualidade, as Passifloras ultrapassaram a visão religiosa e ganharam um papel social e metafórico diferentes, como em tatuagens e na medicina popular e alopática.

O "urucum" (Bixa orellana L.) é o fruto do urucuzeiro ou urucueiro, arvoreta da família Bixaceae. Seu nome genérico vem do Aruaak e Karib. Recebe o nome Nahua "achiote" pelos índios, que o usam na coloração da comida e bebida, podendo ter função ritualística. Também é usado para pintura do rosto e do corpo e protege contra insetos (Oviedo, 1851).

Seu pigmento é oleoso e o tingimento preparado pelos índios era como uma pasta do arilo vermelho, veiculado em óleo, fácil de ser utilizado na pele. Os corantes são a bixina, insolúvel na água e lipossolúvel (Rizzini \& Mors, 1995). As sementes moídas e ingeridas são utilizadas para males cardíacos e estomacais, tosse, bronquite, hemorragias e prisão de ventre (Graig, 1984).

O "pau-brasil" (Paubrasilia echinata (Lam.) - E. Gagnon, H. C. Lima e G. P. Lewis), chamado ibirapiranga, ibirapitanga ou pau-de-tinta, foi o produto de maior valor levado pela metrópole. Significa, na língua indígena, "madeira" ou árvore de cor vermelha. Foi muito usado para tingir roupas e como tinta para escrever; a brazileína é a matéria corante empregada (Pinto, 1995).

Em relação aos cronistas, especificamente no Brasil, iremos neste ponto propor a inversão do raciocínio, dando espaço para apontarmos de forma sucinta a produção de fontes primárias e iconográficas que se colocam como testemunhos da relação das pessoas com as plantas, no passado. Nosso intuito aqui é o de nos despertarmos para a compreensão de que tanto as espécies vegetais quanto as fontes documentais podem se constituir no início de um estudo em etnobotânica histórica (Senna-Valle e Medeiros, 2014).

Vários documentos históricos relevantes trouxeram informações acerca do conhecimento dos habitantes e plantas do Brasil no período colonial, como o de Gabriel Soares de Souza, intitulado Tratado Descritivo do Brasil, de 1587. Outra produção de relevante expressão no Brasil é $A$ narrativa da vontade de Deus: história do Brasil, de Frei Vicente do Salvador, de 1630. Este é considerado o primeiro documento historiográfico do Brasil, em que se apresenta uma ampla descrição da vegetação brasileira.

Não se pode deixar de incluir aqui a notável carta de São Vicente, do Padre José de Anchieta que, em 1560, fez a primeira descrição detalhada da Mata Atlântica (figura 1). São Vicente é a última povoação dos 
portugueses na India Brasilica voltada para o sul. Os escritos do Padre Anchieta são retomados em 1997, por Warren Dean, que faz o registro da história e da devastação da Mata Atlântica.

Figura 1. Representaçăo alegórica do religioso da Companhia de Jesus, 0 Padre José de Anchieta

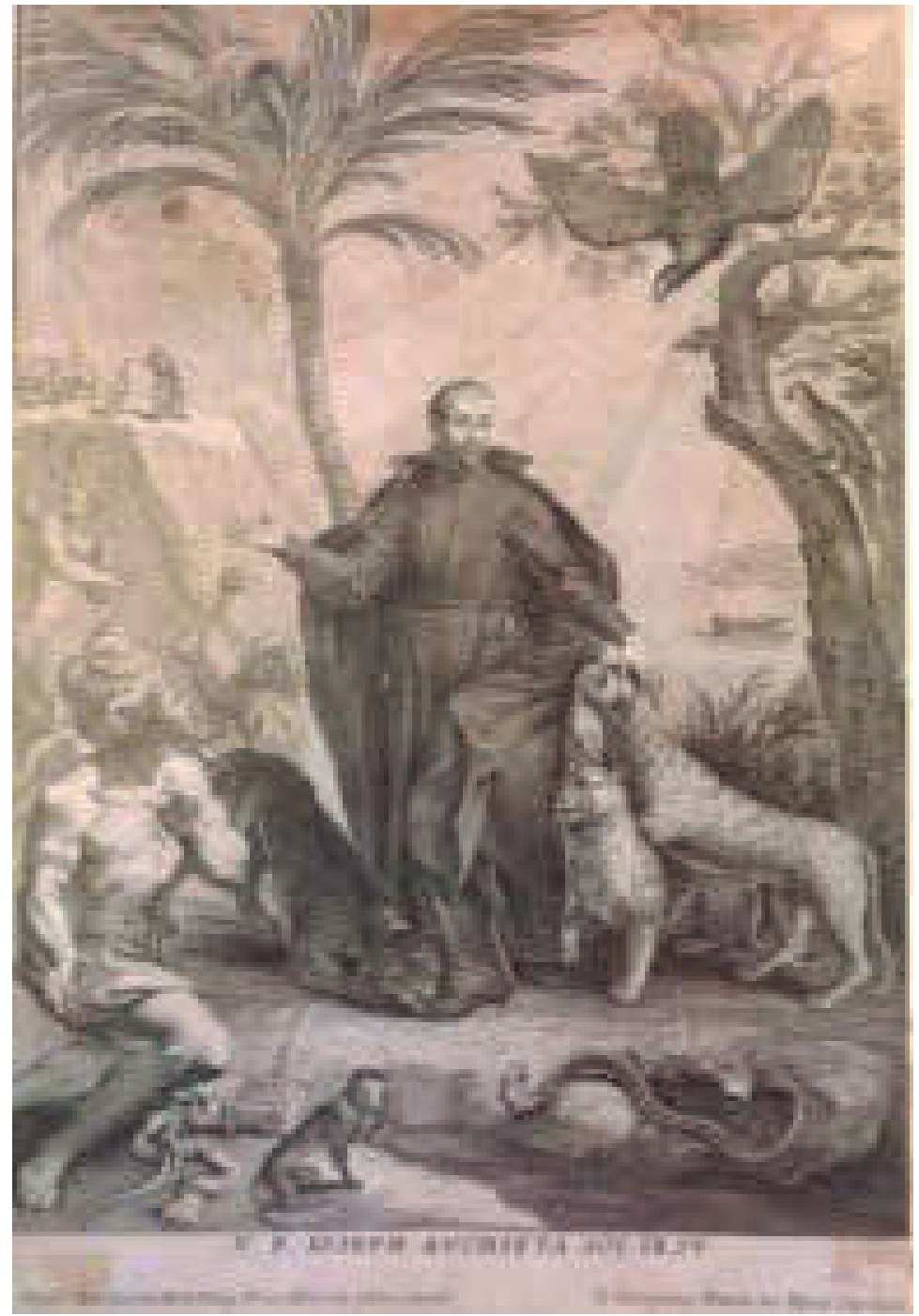

Fonte: Coleçăo Barbosa Machado, n. ${ }^{0} 1.531$, depositada na Biblioteca Nacional, n. ${ }^{0} 17.648$.

Por fim, gostaríamos de nomear um dos mais antigos desenhos da fauna e flora brasileira. Estes foram elaborados no Maranhão por Frei Cristóvão de Lisboa, no ano de 1624 (figura 2). 
Figura 2. A) 0 religioso franciscano, Frei Cristóvăo de Lisboa; B) Uma ilustraçăo do "maracujá" de sua autoria, feita à pena e lápis para a obra História dos Animais e Árvores do Maranhăo. Lisboa, 1624, fólio 120
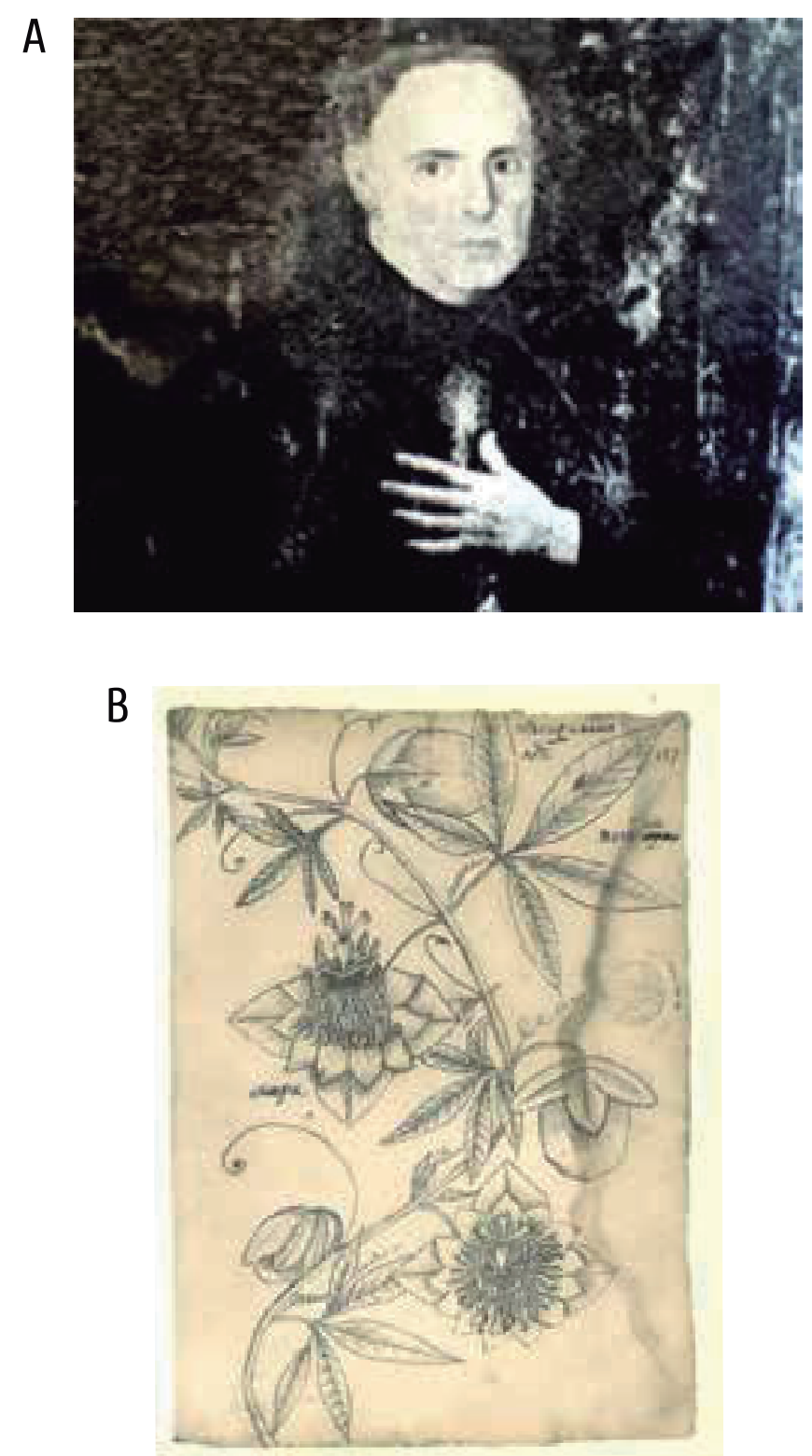

Fonte: Arquivo Histórico Ultramarino, Lisboa, Portugal.

Entre outros arquivos históricos, podemos apontar para os do período da colonização holandesa, no nordeste do Brasil. Foi um dos mais fecundos no que tange o registro dos elementos naturais e do comportamento dos habitantes, durante aquele período. Os registros da flora e da fauna deixadas por Piso e Margraf em sua monumental obra Historia Naturalis Brasiliae de 1648 (figura 3). 
Figura 3. Versăo colorida do frontispício do livro História Naturalis Brasiliae, Piso e Marcgraf (1648): 1) Cajú (Anacardium occidentale L.); 2) Cana-de-açúcar (Saccharum officinarum L.); 3) Coco-da-Bahia (Cocos nucifera L.); 4) Maracujá (Passiflora sp.); 5) Mandioca ou Aipim (Manihot esculenta Crantz); 6) Abacaxi (Annanas comosus (L.) Merr.); 7) Sapucaia (Lecythis pisonis Cambess.); 8) Carnaúba (Copernicia prunifera (Mill.) H. E. Moore)

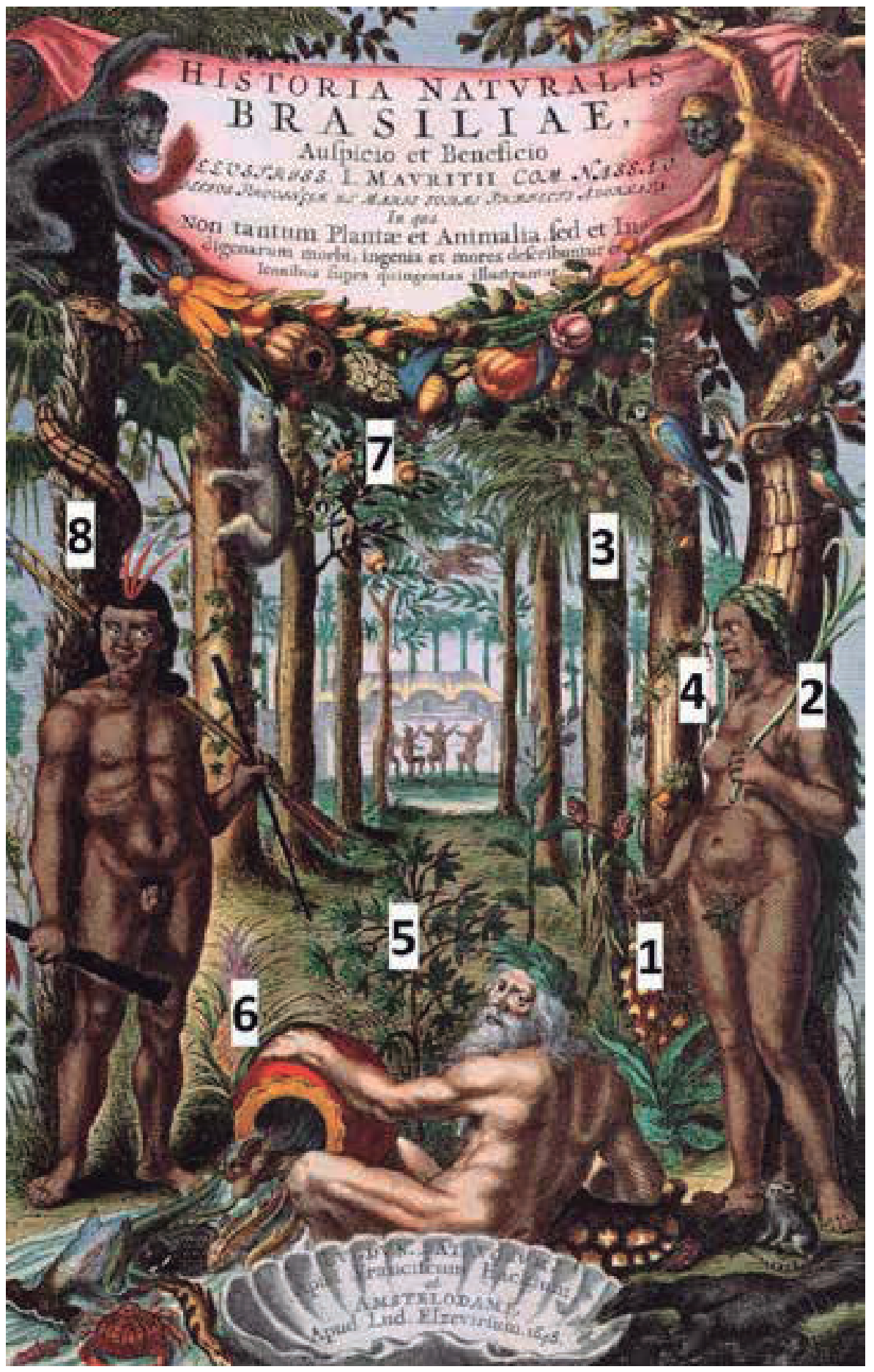


As pinturas e gravuras, pelo pintor Eckholt, sobre o governo de Maurício de Nassau, retratam de modo singular a nossa flora, sua utilização, e a introdução de espécies exóticas, que passavam por um processo de aclimatação em nosso território e que ganharam especial interesse em nosso solo, tomando algumas delas como nossas (figura 4).

Figura 4. Pintura Cabaça, Frutas Cítricas e Cacto, Albert Eckhout século XVII: 1) Gravatá (Bromelia antiacantha Berthol); 2) Cabaça (Lagenaria sp.); 3) Laranja (Citrus sp.); 4) Maracujá (Passiflora edulis Curtis) ramos floridos e frutos; 5) Cardo-cabeça-de-frade (Melocactus sp.)

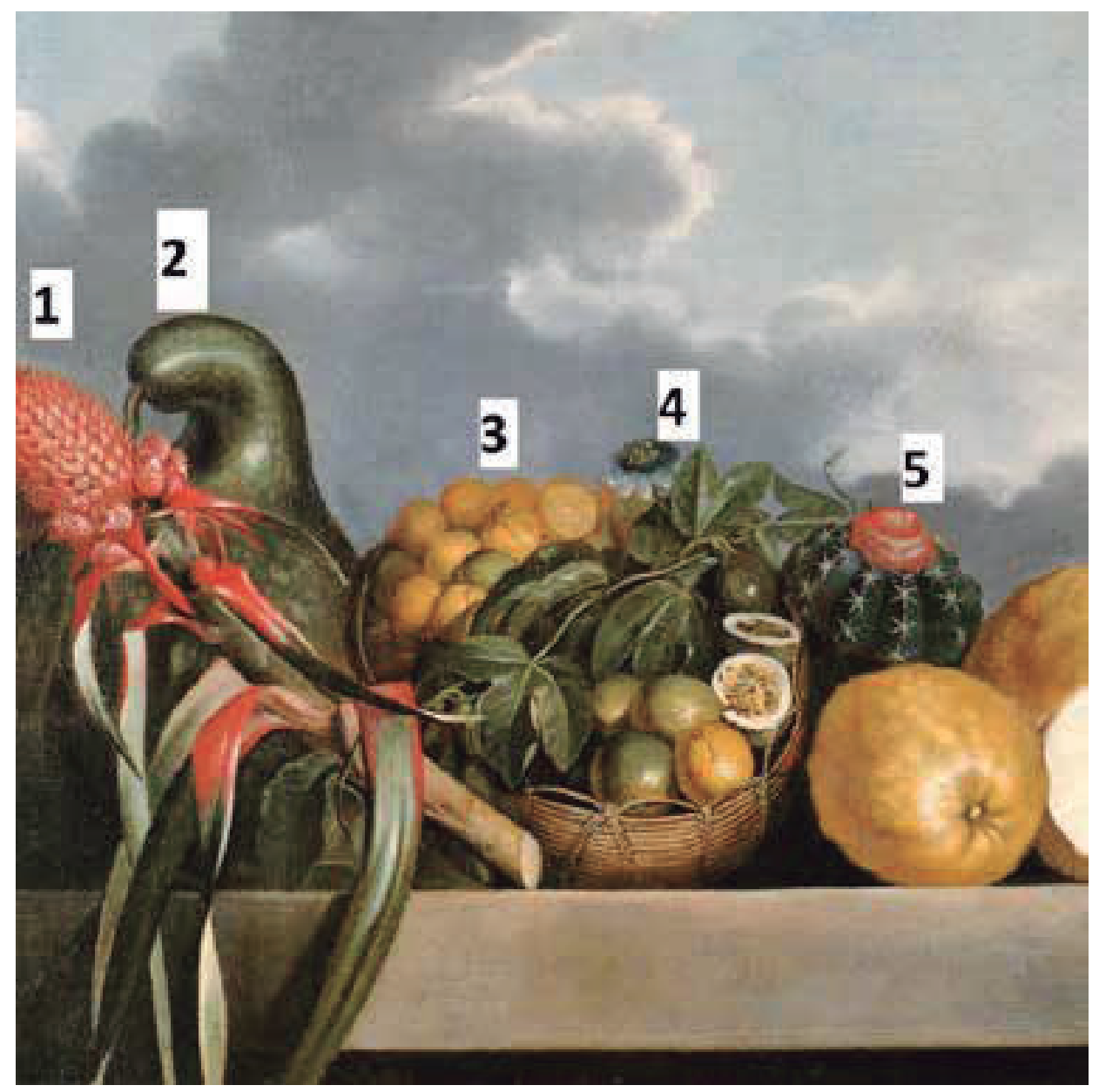




\section{Reflexôes Finais}

Como se vê, todas estas reflexões se assentaram na observação da natureza e da realidade que cercavam esses "pensadores", sejam eles indígenas astecas, maias etc., europeus ou ainda pessoas de outras origens geográficas.

Trazendo para próximo deste diálogo o tema central enfocado pela obra que temos em mão, poderíamos então sugerir, como palavra final deste capítulo e como ponto de inflexão entre passado-presente-futuro, que o planejamento societário para um atualmente tão almejado futuro "sustentável" poderia, ou ainda, deveria beber da fonte (ou das fontes históricas). Não se trata de estudar a história por simples fruição, mas de buscar através dela uma reflexão ampla e profunda do que já vivemos e do que queremos viver. É, em certa medida, retomar as questões basilares da filosofia, que propõe ao homem um novo modo de pensar a realidade. A etnobotânica histórica trata, então, de um novo modo de pensar, em que a velocidade e a atualidade, que torna quase tudo descartável e preso a um único instante, deixam de ser o eixo central para estabelecer que o passado serve como arco de ligação para a busca de explicação da realidade presente e futura, através da reflexão.

\section{Referências}

ALBUQUERQUE, M. A mandioca na Amazônia. Belém: IPEAN; Embrapa, 1969.

e CARDOSO, E. M. R. A mandioca no trópico úmido. Belém: Editerra, 1980.

BAKER, H. G. Las plantas y la civilización. México: Ed. Herrero Hermanos Sucesores S.A., 1968. (Serie Fundamentos de Botánica).

CABRAL, L. M. Plantas e civilização: fascinante história da etnobotânica. Edições de Janeiro, 2016.

CARMARCK, R. M. "Etnohistoria y teoria antropológica”. Cuadernos del Seminario de Integracion Social Guatemalteca, n. 26, Guatemala, 1979. 
CARNEIRO, H. Comida e sociedade: uma história da alimentação. Rio de Janeiro: Campus, 2003.

CERVI, A. C. "Passifloraceae do Brasil: estudo do gênero Passiflora L., subgênero Passiflora”. Fontqueria, v. 45, n. 1, pp. 1-92, Madrid, 1997.

CIENZA DE LEON, P. La prima parte de la cronica del grandissimo Regno del Peru. Roma: Valerio e Luigi Dorici, 1555.

DEAN, W. A ferro e fogo: a história e a devastação da Mata Atlântica brasileira. 1 ed. São Paulo: Cia. das Letras, 1997.

FITAS, A. P. "Da Sociologia da Cultura à Etno-Botânica”. Revista Sítios e Memória, n. 2, pp. 68-75, 1998.

GRAIG, B. Remédios caseiros. Editora Ground LTDA., 1984.

MARTIN, G. J. Etnobotany: a methods manual. Londres: Chapmman and Hall, 1995.

MARTIUS, C. F. von. Natureza, doenças, medicina e remédios dos indios brasileiros. Trad. e notas: Pirajá da Silva. São Paulo: Companhia Editora Nacional, INL/MEC, Brasiliana, 1844.

MEDEIROS, M. F. T. Etnobotânica histórica: princípios e procedimentos. Recife: NUPEEA, 2009.

e ALBUQUERQUE, U. P. (orgs.). Dicionário brasileiro de etnobiologia e etnoecologia. Recife: NUPEEA, 2013.

OVIEDO, G. F. V. Historia general y natural de lãs Índias, islã y tierra-firme del Mar Oceano, 1851.

PINTO, A. C. "O Brasil dos viajantes e dos exploradores e a química de produtos naturais”. Química Nova, v. 18, n. 8, pp. 608-15, 1995.

RIBEIRO, B. G. Índios da América do Sul - Brasil. São Paulo: Brasiliense. 1983.

RIZZINI, C. T. e MORS, W. Botânica econômica brasileira. 1995, pp. 178-9.

SANTOS, L. B. "Reproduzido de tipos e aspectos do Brasil". Coletânea da Revista Brasileira de Geografia. IBGE - Conselho Nacional de Geografia. 8 ed. Rio de Janeiro: Coqueirais, 1966. 
SENNA-VALLE, L. e MANZALI, I. "Etnobotânica histórica: uma abordagem diacrônica nos estudos etnobotânicos". In MOURA, C. W. N. et al. (orgs.). Botânica brasileira: futuro e compromissos. Feira de Santana, 2009, pp. 1083-7.

e MEDEIROS, M. F.T. "Etnobotânica histórica no Brasil” In SILVA, T. R. dos S. et al. (orgs.). Botânica na América Latina: conhecimento, interação e difusão. $11^{\circ}$ Congreso Latinoamericano de Botánica, $65^{\circ}$ Congresso Nacional de Botânica e $34^{\circ}$ ERBOT - MG, BA e ES. Sociedade Botânica do Brasil, Salvador, 2014, pp. 310-6.

VARELLA, L. N. F. Cantos meridionais. Rio de Janeiro: Ed. Eduardo e Henrique Laemmert, 1869, pp. 43-5. 


\section{SOBRE OS AUTORES}

\section{Ana Cecília Bezerra Carvalho}

Graduada em Farmácia pela Universidade Federal da Paraíba (2001). Habilitada em Farmácia Industrial pela Universidade Federal da Paraíba (2002). Especialista em Saúde Internacional pela Universidade de São Paulo (2006) e em Vigilância Sanitária pela Fundação Oswaldo Cruz (2008). Mestre em Produtos Naturais e Sintéticos Bioativos pela Universidade Federal da Paraíba (2005). Doutora em Ciências da Saúde pela Universidade de Brasília (2011). Atualmente é especialista em regulação e vigilância sanitária da Agência Nacional de Vigilância Sanitária (Anvisa), ponto focal da Organização Mundial da Saúde na área de fitoterápicos no Brasil. Membro do Comitê Nacional da Política de Plantas Medicinais e Fitoterápicos e do Comitê Técnico Temático de Apoio a Política Nacional de Plantas Medicinais e Fitoterápicos da Farmacopeia Brasileira. Coordenadora da Câmara Técnica de medicamentos fitoterápicos e da área de registro de medicamentos fitoterápicos e dinamizados da ANVISA. Tem experiência na área de Farmácia, com ênfase em fitoterapia e regulação de fitoterápicos, atuando principalmente nos seguintes temas: fitoterapia, plantas medicinais, saúde pública e fitoterápico. (anacecijp@yahoo.com.br)

\section{Cyl Farney Catarino de Sá}

Graduado em Ciências Biológicas pela Universidade Gama Filho/RJ (1982). Mestre em Ciências Biológicas (Botânica) pela Universidade Federal do Rio de Janeiro (1993). Doutor em Ecologia pela Universidade Federal 
do Rio de Janeiro (2006). Atualmente é Pesquisador III do Instituto de Pesquisa Jardim Botânico do Rio de Janeiro. Desenvolve estudos em florística e estrutura de comunidades vegetais costeiras e taxonomia das Nyctaginaceae do Brasil. (cfarney@jbrj.gov.br)

\section{Joyce Alves Rocha}

Professora de Biologia no ensino médio/técnico do Instituto Federal de Educação, Ciência e Tecnologia do Rio de Janeiro (IFRJ), Campus Paracambi, desde 2006, lecionando a disciplina Biologia I. Doutora em Ciências (2014) pelo Programa de doutorado multidisciplinar em Meio Ambiente da Universidade do Estado do Rio de Janeiro (PPGMA-UERJ), grau obtido com a tese: "Quilombo São José da Serra: o etnoconhecimento na perspectiva socioambiental". Mestre (2000) em Biotecnologia Vegetal pelo Programa em Biotecnologia Vegetal vinculado a Universidade Federal do Rio de Janeiro (PBV-UFRJ). Possui licenciatura em Ciências Biológicas (1994) pela Universidade Federal do Rio de Janeiro e graduação em Ciências Biológicas - modalidade Biologia Vegetal (1997) - pela mesma instituição. Como bióloga, tem experiência na área de Botânica, com ênfase em etnobotânica e conhecimentos tradicionais. Coordenadora do Núcleo de Estudos Afro-brasileiros e Indígenas do IFRJ, campus Paracambi (NEABI CPar), e Membro da Comissão Estadual da Verdade da Escravidão Negra no Brasil CEVENB/OAB-RJ. No IFRJ-Paracambi, compõe as comissões de sustentabilidade, de desfazimento e do Núcleo de Gênero e Diversidade IFRJ. (joycearbio@gmail.com)

\section{Juan Gomes Bastos}

Graduado em Gestão e Planejamento Ambiental pela Universidade Estácio de Sá/RJ (2008). Especialista em Educação Ambiental pelo Instituto Federal Fluminense (2016). Atuou como Guarda-Parques no Instituto Estadual do Ambiente do Rio de Janeiro (2012-2017). Atualmente é mestrando em Biodiversidade em Unidades de Conservação pelo Instituto de Pesquisa Jardim Botânico do Rio de Janeiro. Desenvolve estudos em percepção ambiental e etnobotânica na Região dos Lagos, Rio de Janeiro. (juangb@live.nl) 


\section{Karla Beatriz Lopes Baldini}

Graduada em Ciências Biológicas pelo Centro Universitário de Barra Mansa (2003). Mestre em Ciência Ambiental pela Universidade Federal Fluminense (2006-8). Foi professora substituta do Departamento de Botânica da Universidade Federal de Juiz de Fora (2008-2010), atuando nas disciplinas de Botânica Aplicada e orientando trabalhos na área de etnobotânica. Doutora pelo Programa de Pós-Graduação em Ciências Ambientais e Florestais pela Universidade Federal Rural do Rio de Janeiro, na área de concentração: conservação da natureza (2012-16). Realizou pesquisas durante a graduação com caiçaras na Comunidade do Aventureiro na Ilha Grande, RJ. No mestrado, estudou algumas comunidades do Parque Nacional do Itatiaia e áreas no entorno, continuando até hoje (no doutorado) seus trabalhos na região da Mantiqueira, em regiões rurais no município de Resende, RJ. Atualmente é professora no Curso de Ciências Biológicas na Associação Educacional Dom Bosco, Resende, RJ. (beatriz.karla@gmail.com)

\section{Lana Cláudia Fonseca}

Graduada em Ciências Biológicas licenciatura plena pela Universidade Federal Rural do Rio de Janeiro. Mestrado e doutorado em Educação pela Universidade Federal Fluminense. Professora Associada I da Universidade Federal Rural do Rio de Janeiro, na área de Ensino de Ciências e Biologia. Atua em Ensino de Ciências e Biologia, discutindo a relação entre os saberes populares e o conhecimento científico, principalmente nos seguintes temas: ensino de ciências e biologia, formação de professores e educação popular. Coordena o Grupo de Estudos e Pesquisas em Ensino de Biologia. (lanaclaudiafonseca@gmail.com)

\section{Luci de Senna-Valle}

Professora Titular da Universidade Federal do Rio de Janeiro - Museu Nacional (2015). Graduação em História Natural pela Universidade do Estado do Rio de Janeiro (1972). Mestrado em Ciências Biológicas (Botânica) pela Universidade Federal do Rio de Janeiro (1980). Doutorado em 
Biotecnologia Vegetal pela Universidade Federal do Rio de Janeiro (1999). Orientou, até o momento, 22 alunos, mestrandos e doutorandos sendo treze em etnobotânica e nove em taxonomia. Tem experiência na área de Botânica, com ênfase em etnobotânica em comunidades tradicionais, etnobotânica histórica, herança cultural indígena, portuguesa e africana e também na área de taxonomia: Euphorbiaceae (Actinostemom, Maprounea, Croton e Dalechampia). (lucisenna@gmail.com)

\section{Lucia Regina Rangel de Moraes Valente Fernandes}

Especialista em Indicações Geográficas. Docente do Programa de Pós-Graduação da Academia da Propriedade Intelectual e Inovação e Desenvolvimento do Instituto Nacional da Propriedade Industrial - INPI. Doutora em Processos Químicos e Bioquímicos pela Universidade Federal do Rio de Janeiro (2002). Tem experiência na área de Propriedade Intelectual, atuando principalmente nos seguintes temas: indicação geográfica, conhecimentos tradicionais, prospecção em patentes e indicações geográficas. (luciaregg@inpi.gov.br)

\section{Luiz José Soares Pinto}

Licenciado em Ciências Biológicas pela Faculdade de Formação de Professores da Universidade do Estado do Rio de Janeiro. Mestre e Doutor em Ciências Biológicas (Botânica) pela Universidade Federal do Rio de Janeiro. Atualmente é Professor da Rede Estadual de Ensino do Estado do Rio de Janeiro, atuando no Colégio Estadual David Capistrano. Participa como pesquisador no grupo de Estudos Ambientais no Leste Metropolitano do Rio de Janeiro, nos grupos de pesquisa em biodiversidade, conservação e educação ambiental, etnobotânica e florística da Mata Atlântica. Publicou doze artigos em periódicos especializados e mais de cinquenta trabalhos em anais de eventos, em sua grande maioria na área Botânica. Possui um livro publicado sobre o título de "Plantas Medicinais: Manual de Identificação, Propriedades e Cultivo" (Editora Populis, 2009). Escreveu três capítulos de livro e uma produção em mídia escrita no jornal "O Fluminense". Orientou seis trabalhos de conclusão de curso de graduação. Desenvolve 
projetos sobre a biodiversidade do leste metropolitano do Rio de Janeiro, especialmente dos municípios de Niterói e São Gonçalo. Atua em pesquisas na área de Botânica, com ênfase em etnobotânica e taxonomia vegetal, especialmente das famílias Euphorbiaceae, Phyllanthaceae e Passifloraceae. (ljspinto@gmail.com)

\section{Marcelo Guerra Santos}

Graduação em Ciências Biológicas pela Universidade Federal do Estado do Rio de Janeiro (1995). Mestrado (1999) e doutorado (2007) em Ciências Biológicas (Botânica) pelo Museu Nacional da Universidade Federal do Rio de Janeiro. É professor adjunto, com dedicação exclusiva, do Departamento de Ciências da Faculdade de Formação de Professores (FFP) da Universidade do Estado do Rio de Janeiro (UERJ). Foi coordenador do curso de Pós-graduação (Mestrado Acadêmico) em Ensino de Ciências, Ambiente e Sociedade da FFP/UERJ, onde, atualmente, é professor permanente. Atua na Especialização em Educação Básica (Ensino de Biologia) da FFP/UERJ. Bolsista de Produtividade em Pesquisa do CNPq Nível 2. Pesquisador do Programa de Incentivo à Produção Científica, Técnica e Artística (PROCIENCIA) da UERJ e Jovem Cientista do Nosso Estado (FAPERJ). Líder dos grupos de pesquisa em Estudos Ambientais no Leste Metropolitano do Rio de Janeiro e do grupo Tecnologia de Produtos Naturais. Pesquisador integrante dos grupos de pesquisa Biologia de pteridófitas e Núcleo de Pesquisa e Ensino de Ciências (NUPEC). Membro da Sociedade Botânica do Brasil e da American Fern Society. Desenvolve projetos sobre biodiversidade, com destaque para o leste metropolitano do Rio de Janeiro. Atua em pesquisas na área de Botânica, com ênfase em taxonomia vegetal, etnobotânica, fitoquímica e biologia de pteridófitas. (marceloguerrasantos@gmail.com)

\section{Maria Franco Trindade Medeiros}

Graduação em Ciências Biológicas e Ambientais pela Universidade Santa Úrsula (2000). Mestrado e doutorado em Ciências Biológicas (Botânica) pelo Museu Nacional da Universidade Federal do Rio de Janeiro (2003 e 
2007). Desenvolveu no Instituto de Pesquisa Jardim Botânico do Rio de Janeiro atividade de Apoio Técnico à Pesquisa (2001-2), quando trabalhou em anatomia, morfologia e taxonomia das Combretaceae e Asclepiadaceae. Desenvolveu atividade de inclusão e manutenção de coleção botânica nos herbários da Universidade Santa Úrsula e do Instituto de Pesquisa Jardim Botânico do Rio de Janeiro. Realizou estágio pós-doutoral pelo Programa de Pós-Graduação em Botânica e também pelo de Ecologia, ambos do Departamento de Biologia da Universidade Federal Rural de Pernambuco (2011-12). Desempenhou o secretariado da Sociedade Brasileira de Etnobiologia e Etnoecologia (SBEE) (2009-2010). Desempenhou a presidência da Sociedade Brasileira de Etnobiologia e Etnoecologia (201112). Foi representante Nordeste do Núcleo de Etnobotânica da Sociedade Brasileira de Botânica (SBB). É revisora de periódicos nacionais e internacionais. Desenvolveu atividade de ensino e pesquisa na área de Botânica junto à Pontifícia Universidade Católica do Rio de Janeiro (PUC-Rio). Atualmente é professora adjunta na Universidade Federal de Campina Grande (UFCG), Campus Cuité. É Professora credenciada nos programas de Pós-graduação em Ciências Naturais e Biotecnologia da UFCG e em Etnobiologia e Conservação da Natureza da UFRPE. Atualmente é professora adjunta no Departamento de Botânica - Museu Nacional/Universidade Federal do Rio de Janeiro. Na Botânica, atua desenvolvendo trabalhos com ênfase em Etnobotânica (Etnobotânica histórica, Quantificação em Etnobotânica), Botânica aplicada (Botânica Econômica) e Etnobiologia.(mariaftm@hotmail.com)

\section{Mariana Martins da Costa Quinteiro}

Graduada em Ciências Biológicas pela Universidade Federal Fluminense (2005), em Licenciatura e Bacharelado. Mestre em Ciência Ambiental pela Universidade Federal Fluminense (2008). Doutora em Ciências Ambientais e Florestais pela Universidade Federal Rural do Rio de Janeiro (2012). Tem experiência na área de Conservação, com ênfase em Etnoconservação e Etnobotânica, atuando principalmente nos seguintes temas: conservação da biodiversidade, etnobotânica, etnoecologia, etnoconservação, unidades de conservação e educação ambiental. Criadora do Núcleo de Valorização dos Saberes Tradicionais da Mata Atlântica, realizado com di- 
ferentes parcerias e professora da disciplina Ecologia e Conservação dos Recursos Naturais, na Faculdade Dom Bosco, por dois anos. Atualmente é bolsista de pós-doutorado da CAPES, na área de Etnoconservação, Transformação da paisagem e Sistemas socioecológicos pela Universidade Federal Rural do Rio de Janeiro. (marianaquinteiro@gmail.com.br)

\section{Odara Horta Boscolo}

Professora Adjunta do Departamento de Botânica da Universidade Federal Fluminense. Doutora em Etnobotânica pelo Museu Nacional-Universidade Federal do Rio de Janeiro. Mestre em Botânica pelo Museu Nacional -Universidade Federal do Rio de Janeiro (2003). Graduada em Ciências Biológicas pela Universidade Federal do Rio de Janeiro (2000). Tem experiência na área de Botânica, com ênfase em etnobotânica, botânica econômica e taxonomia, atuando principalmente nos seguintes temas: plantas alimentícias, plantas medicinais, comunidades rurais, conhecimento tradicional e propriedade intelectual. (odaraboscolo@hotmail.com)

\section{Rogério Ribeiro de Oliveira}

Graduado em Comunicação Social na Pontifícia Universidade Católica do Rio de Janeiro. Mestrado e doutorado em Geografia na Universidade Federal do Rio de Janeiro. Pós-doutorado em Geografia na Universidade Alpen-Adria, Áustria (2007). Atualmente é professor associado do Departamento de Geografia e Meio Ambiente da PUC-Rio e membro do corpo docente dos Programas de Pós-Graduação em Geografia da PUC-Rio e de Engenharia Urbana e Ambiental, da PUC-Rio/Universidade de Braunschweig, além de colaborador do Programa de Pós Graduação em Ciências Ambientais e Florestais da UFRRJ. Presentemente está realizando estágio pós-doutoral no Programa de Pós-graduação em Arqueologia do Museu Nacional (UFRJ). Seu interesse maior é o estudo das interações entre sociedade e natureza ao longo do tempo. Suas pesquisas combinam as abordagens da ecologia histórica, da ecologia da paisagem e da história ambiental. (rro@puc-rio.br) 


\section{Sandra Aparecida Padilha Magalhăes Fraga}

Doutora em Ecologia, Conservação e Manejo da Vida Silvestre (Universidade Federal de Minas Gerais, 2002), Mestre em Biologia (Universidade do Estado do Rio de Janeiro,1998), e Graduada em Ciências Biológicas (Universidade do Estado do Rio de Janeiro, 1992). Atualmente é Especialista de Pesquisa, da Divisão de Projetos da Vice Presidência de Ensino, Pesquisa e Inovação (Farmanguinhos/Fiocruz). Foi coordenadora de projetos socioambientais relacionados a plantas medicinais, conhecimentos tradicionais e território, como o Projeto Profito que teve grande relevância para a visibilização da agricultura na Zona Oeste da cidade do Rio de Janeiro. Tem experiência na área de Ecologia Aplicada, atuando principalmente nos seguintes temas: plantas medicinais, agroecologia e saúde, tecnologias sociais, sociobiodiversidade, e desenvolvimento socioambiental territorializado. (sandra.fraga@far.fiocruz.br /magalhaesfraga@gmail.com)

\section{Vanise Baptista da Costa}

Mestre em Propriedade Intelectual e Inovação pelo Instituto Nacional da Propriedade Industrial (INPI), com especialização em Direito Empresarial e formação em Direito. Analista de gestão em saúde da Fundação Oswaldo Cruz - Fiocruz. Foi Coordenadora do Núcleo de Inovação Tecnológica do Instituto Oswaldo Cruz (Fiocruz) - NIT/IOC. Atuou na Cooperação Social do Instituto Oswaldo Cruz. Tem ampla experiência em gestão de organizações sem fins lucrativos. Atualmente está vinculada a Vice-Direção de Gestão e Desenvolvimento do IOC em projetos de inovação. (vanise@ioc.fiocruz.br/vanisebc@gmail.com)

\section{Viviane Stern da Fonseca Kruel}

Graduada em Ciências Biológicas pela Universidade Santa Úrsula - USU/ RJ (1994). Especialista em Botânica/USU (monografia em Etnobotânica - 1994). Mestre em Ciências Ambientais e Florestais no Instituto de Flo- 
restas da Universidade Federal Rural do Rio de Janeiro (2002). Doutora em Botânica pela Escola Nacional de Botânica Tropical/ENBT. Pesquisadora Associada III do Instituto de Pesquisas Jardim Botânico do Rio de Janeiro, na linha de etnobotânica. Desenvolve estudos em etnobotânica, etnoecologia, conservação de plantas úteis; conhecimento tradicional e plantas medicinais. (vfonseca@jbrj.gov.br)

\section{Sobre o ilustrador}

\section{Daniel Ribeiro}

Publicitário, educador, artista plástico e pizzaiolo. Reside em Visconde de Mauá (estado do Rio de Janeiro) há dez anos. 
AS IDEIAS SOBRE O PAPEL dos "saberes tradicionais e/ou locais" estão passando por um processo profundo de reavaliação, especialmente no campo das disciplinas acadêmicas consideradas mais duras. As recentes discussões sobre a conservação da biodiversidade começam a colocar em xeque a suposta autoridade para tratar dessas questões com a qual se revestiu, por exemplo, a biologia. A partir do momento que se admitiu que não faz mais sentido falar desse assunto negligenciando o fato que ele se situa na interface entre natureza e sociedade ficou patente a necessidade de olhar com mais respeito para outros "saberes".

Marcelo Guerra Santos e Mariana Quinteiro, ao selecionarem o conjunto de capítulos que formam este livro, procuraram argumentar que os chamados "saberes tradicionais ou locais" são relevantes para um esforço de relativização, e contextualização, de nossas práticas ligadas à saúde, à educação e ao meio ambiente. Nesse sentido, passando da escala das paisagens, das práticas ligadas aos cuidados com a terra, da produção de alimentos e plantas medicinais para o desafio de enfrentar a diversidade de uma sala de aula, a intenção dos organizadores revela-se na escrita dos autores desta obra que indiscutivelmente fornecem o material necessário para a argumentação dos organizadores.

Saberes Tradicionais e Locais: Reflexões Etnobiológicas oferece uma visão bastante compreensiva da diversidade que se revela no "confronto" entre natureza e cultura e de como manter essa diversidade figura-se como essencial para a chamada sustentabilidade. Os textos compilados oferecem ao leitor as ferramentas para o entendimento do valor dos diferentes saberes, incluindo o acadêmico, e da necessidade do diálogo constante como estratégia de desenvolvimento local.

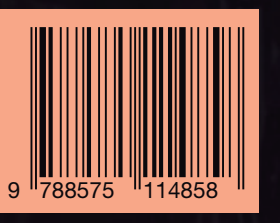

DR. ULYSSES PAULINO DE ALBUQUERQUE Universidade Federal Rural de Pernambuco 